
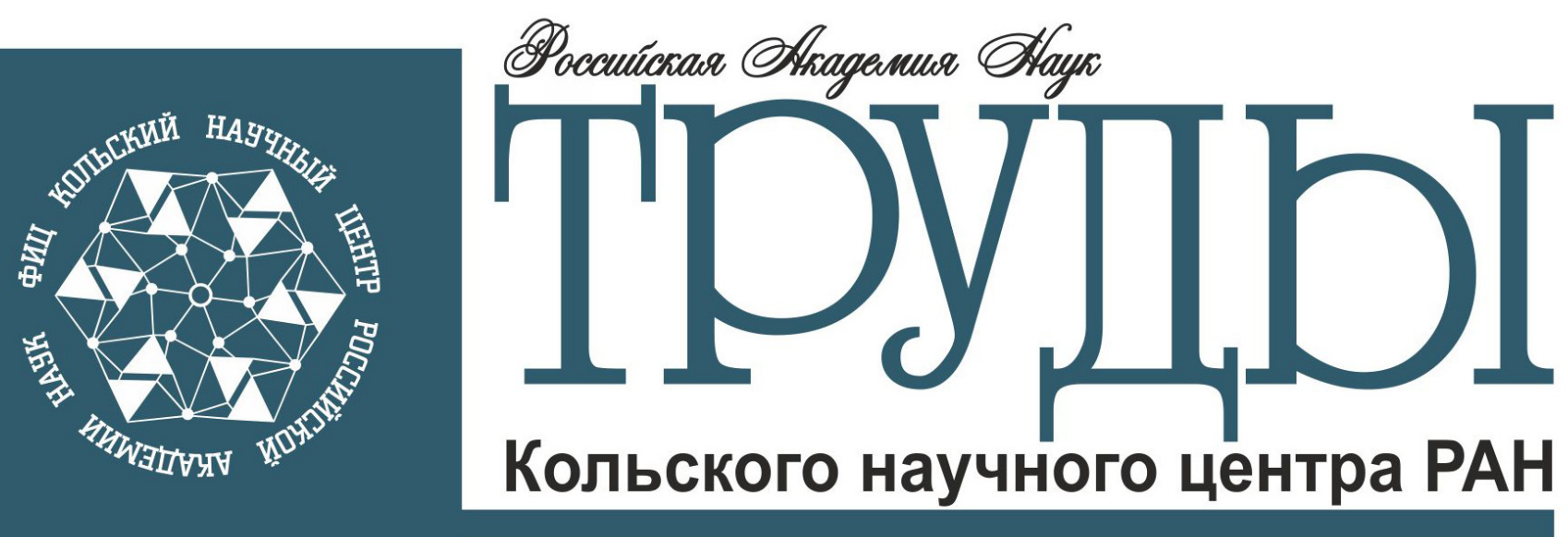

3/2021(12)

ОКЕАНОЛОГИЯ

выпуск 9 
$3 / 2021(12)$

издается с декабря 2010 г.

Удк 551.46

ISSN 2307-5252
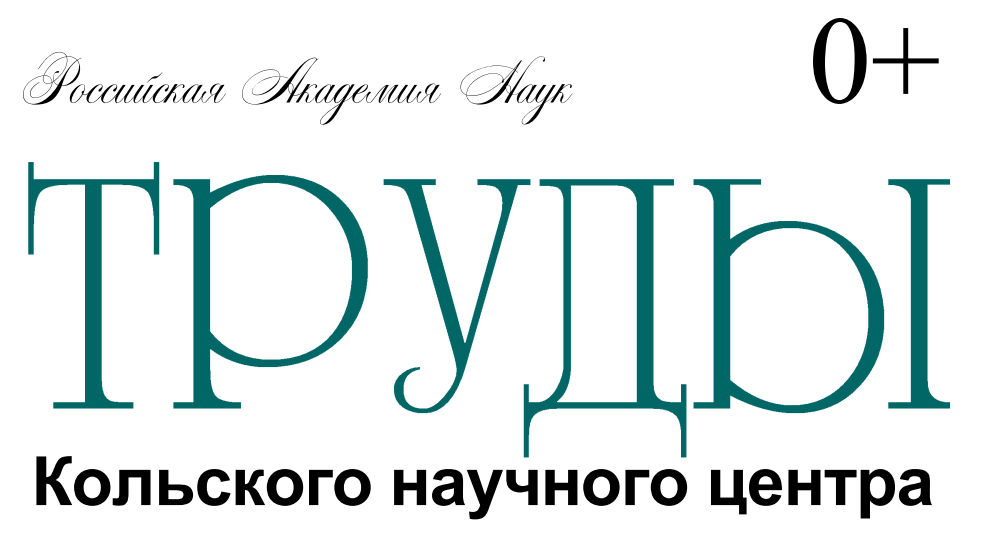

\section{ОКЕАНОЛОГИЯ}

выпуск 9

\section{Научно-информационный журнал \\ Основан в 2010 году}

Выходит 11 раз в год

Учредитель - Федеральное государственное бюджетное учреждение науки Федеральный исследовательский центр «Кольский научный центр Российской академии наук»

Свидетельство о регистрации СМИ

ПИ № ФС77-58457 от 25.06.2014

выдано Федеральной службой по надзору в сфере связи, информационных технологий и массовых коммуникаций.

Главный редактор, председатель Редакционного совета С. В. Кривовичев, чл.-корр. РАН, д. Г.-м. Н., проф.

Заместитель главного редактора

В. К. Жиров, чЛ.-корр.
Редакционный совет:

академик Г. Г. Матишов,

чл.-корр. А. И. Николаев,

д. э. н. Ф. Д. Ларичкин

д. т. н. В. А. Путилов,

д. ф.-М. н. Е. Д. Терещенко,

к. т. Н. А. С. Карпов (отв. секретарь)

Редколлегия серии серии "Океанология": академик Г. Г. Матишов (отв. редактор),

д. б. н. П. Р. Макаревич (зам. Отв. редактора),

д. г. Н. В. В. Денисов,

д. г. н. С. Л. Дженюк,

д. г.-м. н. Г. А. Тарасов,

д. б. н. М. В. Макаров,

к. б. н. О. В. Карамушко,

к. г. н. Г.В. Ильин,

к. б. н. Д. Г. Ишкулов,

к. г. н. Д. В. Моисеев

Ответственный за выпуск М. В. Макаров

Научное издание

Технический редактор В. Ю. Жиганов

Подписано в печать 07.06.2021.

Дата выхода в свет 09.09.2021.

Формат бумаги $70 \times 108$ 1/16.

Усл. печ. л. 14,26. Заказ № 18. Тираж 300 экз.

Свободная цена

Адрес учредителя, издателя и типографии: Федеральное государственное бюджетное учреждение науки

Федеральный исследовательский центр

«Кольский научный центр РАН»

184209 , г. Апатиты, Мурманская обл.,

ул. Ферсмана, 14

Тел.: (81555) 7-53-50; 79-5-95, факс: (81555) 76425

E-mail: ksc@ksc.ru. www.ksc.ru

(с) Федеральное государственное бюджетное учреждение науки

Мурманский морской биологический институт Российской академии наук, 2021 () ФГБУН ФИЦ «Кольский научный центр Российской академии наук», 2021 


\section{ТРУДЫ \\ Кольского научного центра РАН \\ ОКЕАНОЛОГИЯ \\ выпуск 9}

\section{СОДЕРЖАНИЕ}

Стр.

Бердник А.Ф. Динамика формирования диффференцировочного следового условного рефрлекса на звуковые раздражители определенной продолжительности у серого тюленя Halichoerus grypus Fabricius, 1791 методами оперантного обуславливания

Бондарев О.В. Размерный состав и продукционные характеристики сеголеток трески и сайды в губе Зеленецкая (Восточный Мурман) в 2018 году

Булавина А.С. Моделирование стока реки Обь при изменении климата ....

Валуйская Д.А., Чернобыльский след в наземных экосистемах

Ильин Г.В. Северо-Европейского региона

Ващенко A.В. Осенний бактериопланктон открытой и прибрежной части Баренцева моря

Венгер М.П. Вирио- и бактериопланктон Баренцева моря в осенний период

Гурба А.Н. Зимняя авифауна Кольского залива в 2020-2021 гг. 54

Евсеева О.Ю. Мшанки (Bryozoa) морей Лаптевых и ВосточноСибирского: современные исследования

Захарова Л.В., Полифенолы и антиоксидантная активность экстрактов

Облучинская Е.Д. фукусовых водорослей залива Факсафлоуи (море Ирмингера) и бухты Завалишина (Баренцево море)

Максимовская Т.М., Гидрологические исследования в северо-восточной

Ильин Г.В. части Баренцева моря в 2019 и 2020 гг.

Малавенда С.В. Водоросли губы Вересовая Кольского залива (Баренцево море)

Москвин К.К. Полихеты рода Pholoe (Polychaeta: Pholoidae) северо-восточной части Баренцева моря 
Носкович А.Э. Особенности распределения и биологии двустворчатого моллюска Macoma calcarea (Gmelin, 1791) в заливе Грён-фьорд (архипелаг Шпицберген)

Олейник А.А., Состав и распределение микропланктона в Баренцевом

Човган О.В. море в связи с термохалинной структурой пелагиали .....

Пастухов И.А. Гидрохимические исследования на разрезе "Кольский меридиан" с использованием изотопного трассера $\delta^{18} \mathrm{O}$..

Румянцева 3.Ю., Распространение раковинных брюхоногих моллюсков

Нехаев И.О. в открытых частях Баренцева моря: предварительный анализ

Смолькова О.В. Продукционные характеристики поселений двустворчатого моллюска Mya arenaria Linne, 1758 Баренцева моря

Чаус С.А. Пространственное распределение Icelus bicornis (Reinhardt, 1840) и Icelus spatula Gilbert \& Burke, 1912 в морях российской Арктики

Яковлев А.П. Разработка экспериментальной установки для исследования магниторецепции у серых тюленей 


\section{OCEANOLOGY} series 9
Editorial Council:

G. G. Matishov, Acad. of RAS,

A. I. Nikolaev, Cor. Member of RAS,

Deputy Editor-in-Chief: F. D. Larichkin, Dr. Sc. (Economics),

V. K. Zhirov, Cor. Member of RAS V. A. Putilov, Dr. Sc. (Engineering),

E. D. Tereshchenko, Dr. Sc.

(Physics and Mathematics),

A. S. Karpov PhD (Engineering) -

Executive Secretary

Editorial Council

of "Oceanology Series":

G. G. Matishov, Acad. of RAS - Editor-inChief,

P. R. Makarevich, Dr. Sci. (Biology) Deputy Editor-in-Chief,

V. V. Denisov, Dr. Sci. (Geography),

S. L. Dzhenyuk, Dr. Sci. (Geography),

G. A. Tarasov, Dr. Sci. (Geology and

Mineralogy),

M. V. Makarov, Dr. Sci. (Biology),

O. V. Karamushko, PhD (Biology),

G. V. Ilyin, PhD (Geography),

D. G. Ishkulov, PhD (Biology),

D. V. Moiseev, PhD (Geography) 


\section{TRANSACTIONS \\ of the Kola Science Centre \\ OCEANOLOGY \\ series 9}

\section{CONTENTS}

Page

Berdnik A.F. Dynamics of the formation of a differentiation track conditioned reflex to sound stimuli of a certain duration in the gray seal Halichoerus grypus Fabricius, 1791 by the methods of operant conditioning

Bondarev O.V. Size composition and production characteristics of atlantic cod and pollock juveniles of the Zelenetskaya Bay (Eastern Murman) in 2018

Bulavina A.S. Modelling of the Ob river runoff under climat change

Valuyskaya D.A., Radionuclides in marine and terrestrial ecosystems

Ilyin G.V. of the North European region

Vashchenko A.V. Autumn bacterioplankton of the open waters and coastal part of the Barents Sea

Venger M.P. Virio- and bacterioplankton of the Barents Sea in the autumn

Gurba A.N. Winter bird fauna of the Kola Bay in 2020-2021

Evseeva O.Yu. Bryozoa of the Laptev and East Siberian seas: modern research

Zakharova L.V., Polyphenol and antioxidant activity of focus algae extracts Obluchinskaya E.D. from Faksafloi Bay (Irminger Sea) and Zavalishin Bay (Barents Sea)

Maksimovskaya T.M., Hydrological studies in the north-eastern part

Ilyin G.V. of the Barents Sea in 2019 and 2020

Malavenda S.V. Algae of the Veresovaja Bay of the Kola Bay (Barents Sea)

Moskvin K.K. Polychaete genus Pholoe (Polychaeta: Pholoidae) in the north-east region of the Barents Sea

Noskovich A.E. Distribution and biology of the bivalve Macoma calcarea (Gmelin, 1791) in the Grenfjorden (Svalbard) 
Oleynik A.A., Composition and distribution of microplankton in the

Chovgan O.V. Barents Sea in connection with the thermohaline structure of the pelagial

Pastukhov I.A. Hydrochemical studies on the transect "Kola meridian" using the $\delta^{18} \mathrm{O}$ isotope tracer

Rumiantseva Z.Yu., Distribution of shell gastropods in the open parts

Nekhaev I.O. of the Barents Sea: a preliminary analysis .......

Smolkova O.V. Production characteristics of settlements bivalve Mya arenaria Linne, 1758 of the Barents Sea

Chaus S.A. Spatial distribution of Icelus bicornis (Reinhardt, 1840) and Icelus spatula Gilbert \& Burke, 1912 in the russian Arctic seas

Yakovlev A.P. Development of an experimental installation for gray seal magnetoreception research 
DOI: 10.37614/2307-5252.2021.3.9.001

УДК $636.02+623.98$

\author{
А.Ф. Бердник \\ Мурманский морской биологический институт РАН, г. Мурманск, Россия
}

ДИНАМИКА ФОРМИРОВАНИЯ ДИФФЕРЕНЦИРОВОЧНОГО СЛЕДОВОГО

УСЛОВНОГО РЕФЛЕКСА НА ЗВУКОВЫЕ РАЗДРАЖИТЕЛИ ОПРЕДЕЛЕННОЙ

ПРОДОЛЖИТЕЛЬНОСТИ У СЕРОГО ТЮЛЕНЯ HALICHOERUS GRYPUS

FABRICIUS, 1791 МЕТОДАМИ ОПЕРАНТНОГО ОБУСЛАВЛИВАНИЯ

\begin{abstract}
Аннотация
В процессе исследований 15-летняя самка серого тюленя была обучена нажимать на кнопку после демонстрации звукового длительностью 5 с и игнорировать аналогичные звуковые сигналы большей или меньшей длительности. Проведенные работы продемонстрировали способность подопытного тюленя достоверно диффференцировать звуковые сигналы через 3 с. Описаны изменения во времени реакции и поведении тюленя при демонстрации звуковых раздражителей с различимыми и неразличимыми временными диапазонами.
\end{abstract}

Ключевые слова: серый тюлень, следовой условный рефрлекс, временные интервалы.

\author{
A.F. Berdnik \\ Murmansk Marine Biological Institute RAS, Murmansk, Russia \\ DYNAMICS OF THE FORMATION OF A DIFFERENTIATION TRACK \\ CONDITIONED REFLEX TO SOUND STIMULI OF A CERTAIN DURATION \\ IN THE GRAY SEAL HALICHOERUS GRYPUS FABRICIUS, 1791 \\ BY THE METHODS OF OPERANT CONDITIONING
}

\begin{abstract}
In the course of the study, a 15-year-old female gray seal was trained to press a button after displaying an audio signal for 5 seconds and ignore similar audio signals of longer or shorter duration. The conducted research has demonstrated the ability of the experimental seal to reliably differentiate sound signals with a difference in sound duration of 3 seconds. Changes in the reaction time and behavior of the seal during the demonstration of sound stimuli with distinguishable and indistinguishable time ranges are described.
\end{abstract}

Keywords: gray seal, trace conditioned reflex, time intervals.

Введение. Восприятие времени у животных играет важную роль в целом ряде поведенческих процессов от вокализации и охоты до размножения. Время и его восприятие соединено с множеством когнитивных процессов (например, внимание и память) (Matthews, Meck, 
2016) и, как следствие, является одним из ключевых аспектов жизни животных. Для восприятия времени не существует конкретного органа, получающего перманентную информацию, более того, в зависимости от длительности временного отрезка могут быть задействованы разные области мозга при обработке воздействующих в данный момент стимулов. Исследования в этой области проведены на множестве животных, включая голубей (Differential ..., 2007), крыс (Whitaker et al., 2003) и кошек (Rosenkilde, Divac, 1976), с применением разных методик и с различными временными интервалами.

Связь временного восприятия с физиологическими особенностями и выработкой рефлексов легла в основу множества теорий о системах оценки продолжительности. Многие исследователи связывают такое восприятие с физиологией, размерами животного или определенным образом жизни. Одной из наиболее распространенных теорий в этой области является теория ожидаемого скалирования (Gibbon et al., 1984). В основу данной теории положено предположение о внутренних часах, состоящих из пэйсмейкер-накопительного компонента. Проецируемые нейроном-пэйсмейкером импульсы сохраняются в накопителе, в результате количество импульсов формирует определенную частоту и ложится в основу восприятия времени. Одним из основных аттракторов пейсмейкернакопительного комплекса является сердечно-сосудистая система. Высокий пульс увеличивает частоту накопления, приводя к избыточной стимуляции субъективного восприятия, в то время как сниженный пульс приводит к обратному эффекту (Zakay, Block, 1996). Однако, помимо физиологической составляющей, воздействие на восприятие времени также оказывает множество других факторов - движение, стресс, возраст (Wearden, Penton-Voak, 1995). Время напрямую связано с выработкой условных рефлексов, так как одной из важнейших особенностей в данном процессе является время выработки нейрофизиологических изменений (Wittmann, Wassenhove, 2009).

При сравнении способностей у обыкновенного тюленя Phoca vitulina и южноафриканского морского котика Arctocephalus pusillus pusillus, где рассматривался широкий временной диапазон (от субсекундных значений до 7-8 с), установлена способность дифференцировать интервалы до 2 с, а также различать субсекундные (Heinrich et al., 2020).

В соответствии с вышесказанным, нами были выдвинуты предположения о возможности выявления наименьшего определяемого временного интервала у серого тюленя методами оперантного обуславливания при использовании в качестве стимула звуковых раздражителей разной длительности. Ранее была установлена возможность приобретения условного рефлекса у самки серого тюленя (Бердник, 2020), вырабатываемого на след от действия сигнального раздражителя через $5 \mathrm{c}$. 
Цель исследований - установить возможность выработки дифференцировочного следового условного рефлекса, изучить динамику формирования и определить минимальное время, спустя которое начинает реагировать тюлень.

Материал и методы. Эксперимент проводился в условиях аквакомплекса ММБИ РАН (г. Полярный) на акватории Кольского залива. Подопытным животным выступала 15-летняя самка серого тюленя Halichoerus grypus Fabricius, 1791, ранее участвовавшая в экспериментах по выработке условных рефлексов на различные раздражители.

Для корректировки действий применялись методы оперантного обуславливания: положительное подкрепление в виде пищевого поощрения и отрицательное наказание - временной штраф с сопутствующими бридж-сигналами. Сотрудниками лаборатории биотехнических систем была разработана экспериментальная установка (рис. 1), позволяющая в автоматическом режиме генерировать звуковой сигнал, задавать время звучания, отслеживать нажатие кнопки и вести протокол исследований.

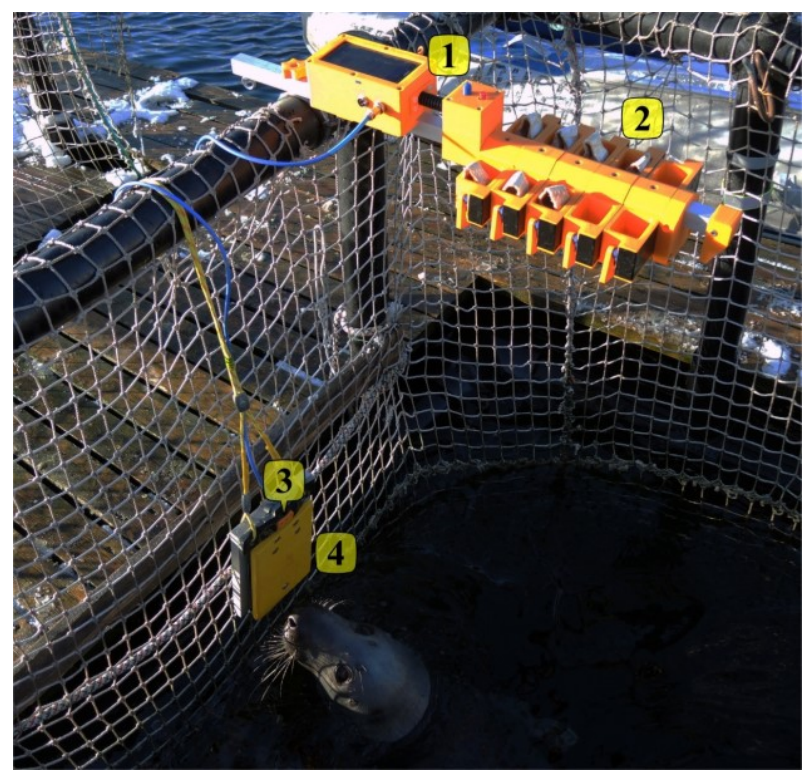

Рис. 1. Схема экспериментальной установки:

1 - блок управления; 2 - блок контейнеров с рыбным кормом; 3 пьезоэлектрический динамик в кожухе; 4 - кнопка для взаимодействия с тюленем

Fig. 1. Schematic of the experimental setup:

1 - control unit; 2 - block of containers with fish feed; 3 - piezoelectric speaker in the casing; 4 - button for interacting with the seal

Схема работы на каждой тренировке, как обучающей, так и контрольной, выглядела следующим образом. Оператор закреплял экспериментальную установку в вольере и включал ее. После самотестирования, установка подавала сигнал о готовности к работе. 
Оператор загружал рыбу в контейнеры, нажатием кнопки запускал эксперимент и уходил от вольера в зону вне видимости тюленя. Система автономно проводила 10 циклов опытов и после опустошения контейнеров сигнализировала оператору о завершении. Оператор возвращался к вольеру, оценивал готовность тюленя к продолжению работы и либо останавливал эксперимент, либо принимал решение о продолжении. В этом случае оператор снова загружал рыбу в контейнеры и запускал новые циклы эксперимента.

В каждом опыте система сначала выдерживала паузу в случайном диапазоне от 5 до 15 с, затем генерировала синусоидальный чистый тон на частоте 3200 Гц. Время звучания с шагом в 1 с составляло от 1 до 9 с. Звуковые отрезки генерировались триплетами, в который входили следующие временные отрезки: подкрепляемый - 5 с, неподкрепляемый $1,2,8,9$ с и неподкрепляемый неразличимый $-3,4,6,7$ с. Очередность сигналов в триплете и последовательность триплетов генерировалась псевдослучайным методом по схеме - не более двух повторов подряд. Если тюлень после завершения звучания 5-секундного отрезка в течение 5 с нажимал на кнопку, то система воспроизводила бридж-сигнал положительного подкрепления и открывала соответствующий контейнер для подачи пищевого поощрения. Затем выдерживала паузу в 10 с, давая тюленю возможность съесть корм, и запускала новый цикл. Если тюлень нажимал на кнопку после воспроизведения неподкрепляемого отрезка во время воспроизведения или в период задержки, то система воспроизводила бридж-сигнал наказания и прекращала работу на 10 с.

Система самостоятельно останавливала эксперимент в случае, если тюлень более 5 раз подряд игнорировал подачу подкрепляемого звукового сигнала и если тюлень начинал постоянно бессистемно нажимать или удерживать нажатой кнопку, то каждые 2 с ему начислялись 10 с штрафных при наборе суммарного времени ожидания более 120 с. В этих случаях система прекращала опыт и сигнализировала оператору.

На каждой тренировке оценивались количество верных выборов и время реакции, а также изменения в поведении тюленя.

Результаты и обсуждение. Ранее нами было установлено (Бердник, 2020), что для выработки следового условного рефлекса у тюленя требуется в 2 раза больше опытов, чем при выработке таковых на звуковые (Литвинов, Пахомов, 2019), обонятельные (Литвинов, Пахомов, 2018) и зрительные раздражители (Пахомов, 2020). В то же время при обучении дифференцировке одномодальных стимулов количество опытов, достаточных для формирования стойкого дифференцировочного условного рефлекса, когда доля выборов значительно выше вероятности случайного угадывания, - около 100.

В данном исследовании работу с тюленем продолжили с демонстрации звука длительностью 5 с. Когда тюлень в течение трех тренировок подряд нажимал на кнопку только после прекращения 
звучания, ввели новый стимул - звук с такими же амплитудночастотными характеристиками, но с длительностью звучания 1 с. Тюлень по результатам четвертой тренировки показал результат в 87 \% верных выборов, при общем количестве предъявлений неподкрепляемого стимула -80 опытов. При введении второго неподкрепляемого стимула в 9 с тюленю понадобилось еще пять тренировок с общим количеством предъявлений в 100 опытов, чтобы доля верных выборов составила 100 \%. Следует отметить, что тюлень нажимал на кнопку только после окончания звучания стимулов, хотя предполагалось, что при демонстрации звука длительностью 9 с тюлень будет совершать ошибочные нажатия через 5 с. При введении звуковых стимулов длительностью 2 и 8 с каких-либо изменений в доле верных выборов выявлено не было. Это свидетельствует о том, что тюлень, во-первых, отличает данные временные отрезки от подкрепляемых 5-секундных, а, во-вторых, не отличает эти временные отрезки от 1 и 9 с соответственно. При введении звуковых отрезков длительностью 3 и 7 с тюлень изначально не отличал их от 5-секундного отрезка, но затем доля верных выборов при дифференциации разницы во времени звучания в 2 с начала возрастать с третьей тренировки и достигла $100 \%$ на пятнадцатой, сохранившись для обоих отрезков до конца эксперимента. Одновременно с временными отрезками в 3 и 7 с введены отрезки в 4 и 6 с, такую разницу во времени тюлень не различал, доля верных выборов если и поднималась, то не выше 30 \% за тренировку, что свидетельствует о случайности таких выборов. В этот же период доля верных выборов при демонстрации подкрепляемого стимула длительностью 5 с снизилась, так как на четвертой тренировке тюлень начал нажимать на кнопку после демонстрации каждого отрезка длительностью от 3 до 7 с хаотически, явно пытаясь угадать. Результаты контрольных тренировок представлены на рис. 2.

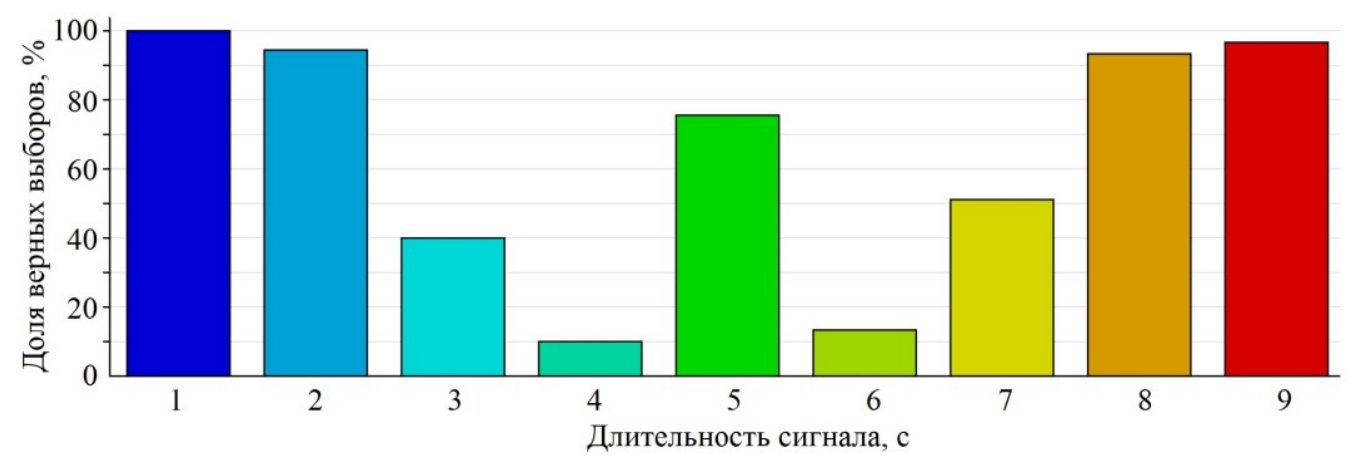

Рис. 2. Результаты контрольных тренировок

Fig. 2. Results of control trainings

Изменялось и время реакции при верном и неверном выборе. Изначально, при демонстрации только 5-секундного отрезка среднее 
за тренировку время реакции постепенно снижалось, и на третьей тренировке достигло 3.27 с. При введении отрезка в 1 с среднее время реакции возросло до 3.94 с, затем плавно снижалось до 2.78 с, что сопоставимо с временем реакции данного тюленя при выработке дифференцировочного условного рефлекса на звуковые (Литвинов, Пахомов, 2019) и зрительные стимулы (Пахомов, 2020). При введении 9-секундного отрезка картина была схожая - сначала увеличение времени реакции до 3.9 с и постепенное снижение до 2.45-2.84 с. При введении 2- и 8-секундного отрезков среднее время реакции не изменялось, при 3-, 4-, 6- и 7-секундном в течение первых двух тренировок среднее время реакции также не изменялось, но доля верных выборов значительно снизилась. На третьей тренировке среднее время реакции катастрофически выросло и составило 4.38 с, а при визуальном наблюдении за тюленем было видно, что животное долго тянет с ответом, особенно возбуждаясь при демонстрации в диапазоне 3-7 с, при 1, 2, 8 и 9 с тюлень был более спокоен. На четвертой тренировке среднее время составило 3.83 с, а на последующих снизилось до 2.87-3.31 с и сохранялось до конца эксперимента.

Заключение. Изучена динамика формирования следового дифференцировочного условного рефлекса на звуковой раздражитель. Показано, что подопытный тюлень способен различать временные отрезки длительностью до 2 с.

Дальнейшее использование данной методики позволит выработать команды, связанные с дифференциацией определенных временных промежутков и реакцией на раздражители, а также исследовать восприятие и оценку морскими млекопитающими времени и их способности к запоминанию временных отрезков.

\section{Литература}

Бердник А.Ф. Возможность выработки следового условного рефлекса на звуковой раздражитель у серого тюленя // Тр. Кольского науч. центра РАН. 2020. Т. 11(5). Сер. Океанология. Вып. 8. С. 7-11.

Литвинов Ю.В., Пахомов М.В. Исследование обоняния серых и гренландских тюленей с помощью метода оперантного обучения // Вестн. Мурм. гос. техн. ун-та. 2018. Т. 21, № 2. С. 336-343.

Литвинов Ю.В., Пахомов М.В. Исследование способности серых тюленей дифференцировать сложносоставные звуковые сигналы // Вестн. Мурм. гос. техн. ун-та. 2019. Т. 21, № 2. С. 245-251.

Пахомов М.В. Исследование способности серых тюленей дифференцировать источники света с разными длинами волн // Тр. Кольского науч. центра РАН. 2020. Т. 11(5). Сер. Океанология. Вып. 8. С. 125-132.

Differential effects of empty and filled intervals on duration estimation by pigeons: tests of an attention-sharing explanation / A. Santi, D. Keough, S. Gagne, P. van Rooyen // Behavioral Process. 2007. Vol. 74. P. 176-186. 
Gibbon, J., Church R.M., Meck W.H. Scalar timing in memory // Annual New York Acad. Sci. 1984. Vol. 423. P. 52-77.

Heinrich T., Ravignani A., Hanke F.D. Visual timing abilities of a harbour seal (Phoca vitulina) and a South African fur seal (Arctocephalus pusillus pusillus) for sub- and supra-second time intervals // Nature. 2020. Vol. 23. P. 851-862.

Matthews W.J., Meck W.H Temporal cognition: connecting subjective time to perception, attention and memory // Psychological Bull. 2016. Vol. 142. P. 805-907.

Rosenkilde C.E., Divac I. Discrimination of time intervals in cats // Acta Neurobiologica. 1976. Vol. 36. P. 311-317.

Wearden J.H., Penton-Voak I.S. Feeling the heat: body temperature and the rate of subjective time, revisited // J. Experimental Psychology. 1995. Vol. 48. P. 129-141.

Whitaker S., Lowe C.F., Wearden J.H. Multiple-interval timing in rats: performance on two-valued mixed fixed-interval schedules // J. Experimental Psychology. 2003. Vol. 29. P. 277-291.

Wittmann M., Wassenhove $V$. The experience of time: neural mechanisms and the interplay of emotion, cognition and embodiment // Phil. Trans. Royal Society. 2009. Vol. 364, № 1525. P. 1809-1813.

Zakay D., Block R.A. The role of attention in time estimation processes // Advanced Psychology. 1996. Vol. 115. P. 143-164.

DOI: $10.37614 / 2307-5252.2021 .3 .9 .002$

УДК $597.5+268.45$

\section{О.В. Бондарев}

Мурманский морской биологический институт РАН, г. Мурманск, Россия

\section{РАЗМЕРНЫЙ СОСТАВ И ПРОДУКЦИОННЫЕ ХАРАКТЕРИСТИКИ СЕГОЛЕТОК ТРЕСКИ И САЙДЫ В ГУБЕ ЗЕЛЕНЕЦКАЯ (ВОСТОЧНЫЙ МУРМАН) В 2018 ГОДУ}

\section{Аннотация}

Представлены данные по росту сеголеток трески Gadus morhua Linnaeus, 1758 и сайды Pollachius virens (Linnaeus, 1758) в губе Зеленецкая в 2018 г. Рассчитаны суточная удельная скорость роста и продукции. Длина сеголеток трески в июлесентябре варьировала от 3.5 до 7.9 см, сайды - от 2.5 до 9.4 см. Суточная удельная скорость весового роста $\left(q_{\mathrm{w}}\right)$ сеголеток трески с июля по август составила 0.41, с августа по сентябрь - 1.08, для сеголеток сайды эти показатели равны 1.32 и 0.94 соответственно. Суточная удельная продукция (С) сеголеток трески в губе за летний период варьировала от 0.015 до 0.036, а сеголеток сайды от 0.011 до 0.042 .

Ключевые слова: рост, продукция, треска, сайда, прибрежье, Баренцево море. 
O.V. Bondarev

Murmansk Marine Biological Institute RAS, Murmansk, Russia

\section{SIZE COMPOSITION AND PRODUCTION CHARACTERISTICS OF ATLANTIC COD AND POLLOCK JUVENILES OF THE ZELENETSKAYA BAY (EASTERN MURMAN) IN 2018}

Abstract

In this article presented data on the growth of the atlantic cod Gadus morhua Linnaeus, 1758 and pollock Pollachius virens (Linnaeus, 1758) juveniles in Zelenetskaya Bay in 2018. The daily specific growth rate and production rate were calculated. The length of atlantic cod juveniles in July-September varied from 3.5 to $7.9 \mathrm{~cm}$, and pollock - from 2.5 to $9.4 \mathrm{~cm}$. The daily specific weight growth rate $\left(q_{\mathrm{w}}\right)$ of atlantic cod juveniles in Zelenetskaya Bay from July to August was 0.41, and from August to September - 1.08; for pollock juveniles, these indicators are 1.32 and 0.94 , respectively. The daily specific production $(C)$ of atlantic cod juveniles in Zelenetskaya Bay over the summer period varied from 0.015 to 0.036 , and of pollock juveniles - from 0.011 to 0.042 .

Keyword: growth, production, atlantic cod, pollock, coastal, Barents Sea.

Введение. Первые ихтиологические исследования в губах Восточного Мурмана проводились на базе Мурманской биологической станции и Мурманского морского биологического института АН СССР в 1936-1970-х гг. (Камшилов, Миронова, 1950; Миронова, 1951, 1956, 1957; Чумаевская-Световидова, 1955; Чугунова, 1967). Однако распределение и биоразнообразие рыб этого района впервые стало рассматриваться О.Ю. Кудрявцевой с 2008 г. По результатам многолетнего мониторинга установлено (Кудрявцева, 2019), что прибрежная зона играет важную роль в формировании рыбной части сообщества, а доминирующими видами рыб являются сеголетки атлантической трески Gadus morhua Linnaeus, 1958 и сайды Pollachius virens (Linnaeus, 1958). Плотность распределения и биомасса рыб из года в год колеблются, максимальные значения у сайды - 162.5 тыс. экз/га и 132.7 кг/га соответственно, тем самым оказывая влияние на биоразнообразие прибрежной ихтиофауны (Основные ..., 2020).

Данная работа является продолжением исследований, в которых уже были рассмотрены видовой состав и его количественные характеристики, изучено питание и рост доминирующих видов рыб в отдельные годы (Ихтиофауна ..., 2014; Представители ..., 2015; Кудрявцева, 2015, 2017, 2018, 2019; Бондарев, 2017, 2020; Кудрявцева, Кудрявцева, 2017; Основные ..., 2020).

При расчетах генеративной продукции используют показатель биомассы сеголеток на конец года. Лишь некоторые работы посвящены оценке продукции молоди рыб (Estuarine ..., 2008; Колпаков, 2010, 2016, 2018; Расхожева, 2010, 2018). Нами выполнен расчет продукции сеголеток трески и сайды в губах Восточного Мурмана в летний период 2018 г. 
Материал и методы. Материал для работы собран в июле-сентябре 2018 г. в губе Зеленецкая (рис. 1). Облов проводили с помощью 15 -метровой мальковой волокуши (высота -1.8 м; ячея дели в крыльях 6 мм, в горловине - 5 мм, в куту -4 мм). Площадь одного облова волокушей варьировала от 100 до $350 \mathrm{~m}^{2}$, продукционные показатели были рассчитаны на $2050 \mathrm{~m}^{2}$.

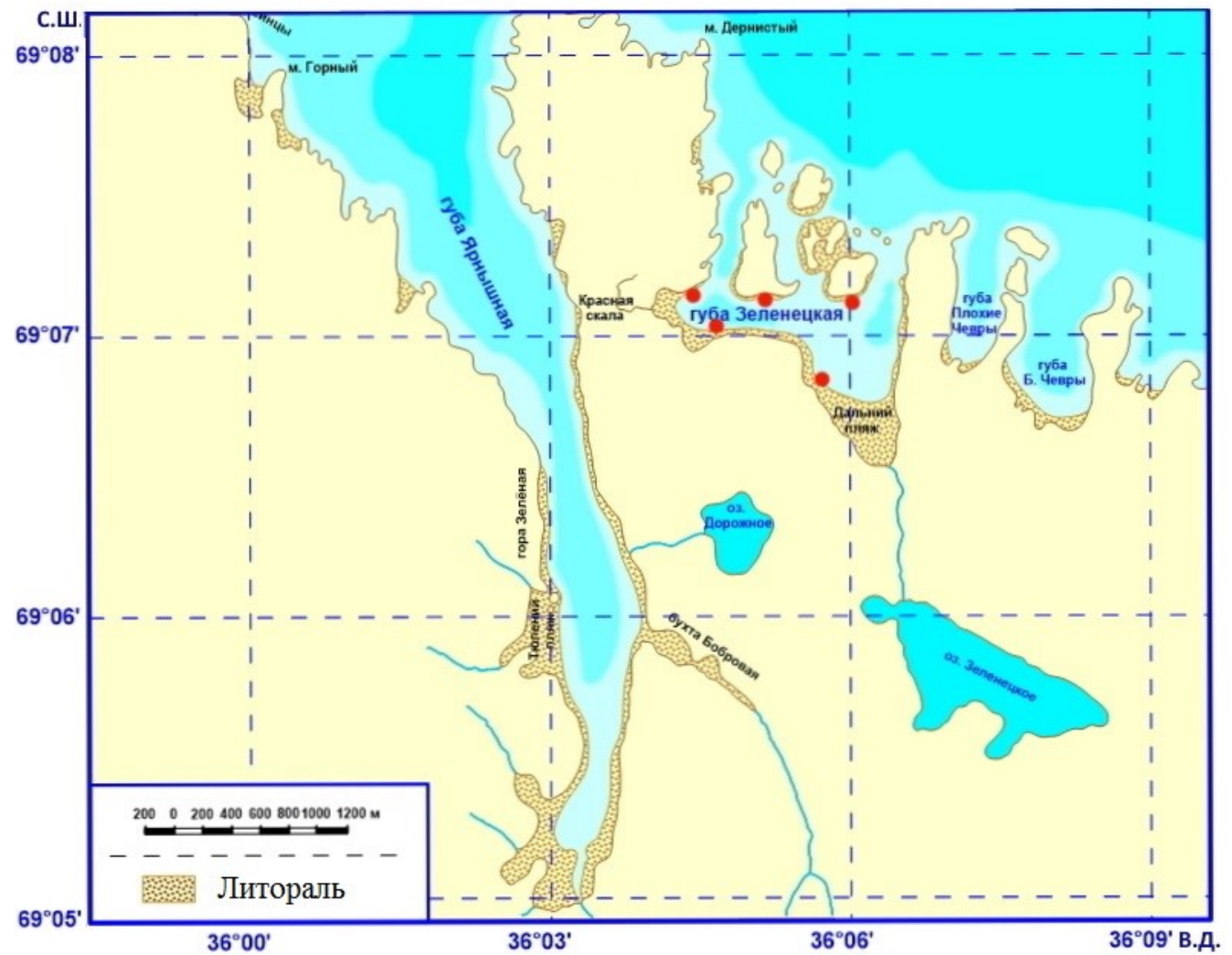

Рис. 1. Карта-схема станций отбора ихтиологических проб Fig. 1. Map of ichthyological sampling stations

У рыб измеряли абсолютную длину тела $T L$ (от вершины рыла до конца наиболее длинных лучей хвостового плавника), взвешивание проводили на торсионных весах с точностью до 0.01 г. Всего обработано 203 экз. трески и 572 экз. сайды. Первоначальная биомасса сеголеток трески составляла 25.7 г, сайды - 483.5 г на $550 \mathrm{~m}^{2}$.

Среднюю удельную скорость роста массы тела вычисляли по формуле (Винберг, 1966)

$$
q_{\mathrm{w}}=\frac{\ln W_{\mathrm{n}+1}-\ln W_{\mathrm{n}}}{t_{\mathrm{n}+1}-t_{\mathrm{n}}},
$$

где $W_{\mathrm{n}+1}$ и $W_{\mathrm{n}}-$ средняя масса рыб в возрасте $t_{\mathrm{n}+1}$ и $t_{\mathrm{n}}$, г. 
Соматическая продукция $P_{\mathrm{s}}$ была рассчитана по одноразовой выборке (Максимович, Погребов, 1986; Алимов и др., 1990):

$$
P_{\mathrm{s}}=\left(\frac{N_{\tau}+N_{\tau-1}}{2}\right)\left(W_{\tau}-W_{\tau-1}\right),
$$

где $P_{\mathrm{s}}$ - соматическая продукция возрастной группы (когорты); $W_{\tau}-$ средняя общая масса особей возраста $\tau ; N_{\tau}$ - численность особей в возрасте $\tau$.

Суточную удельную продукцию популяции определяли как отношение суточной продукции $P$ к среднему значению биомассы $B$ за конкретный период (число дней между обловами) (Заика, 1983):

$$
C=\frac{P}{B}
$$

Результаты и обсуждение. Рассматривая размерный состав сеголеток трески в губе Зеленецкая можно отметить следующее. В июле 2018 г. длина рыб варьировала от 3.5 до $6.0 \mathrm{~cm}$, основную долю (58 \%) составляли особи длиной от 4.5 до 5.4 см (рис. 2). В августе отсутствовали мелкие рыбы длиной до 4 см, но отмечались особи длиной до 7.9 см. К сентябрю наблюдается снижение численности рыб, а их длина колеблется от 6 до $7.4 \mathrm{~cm}$.

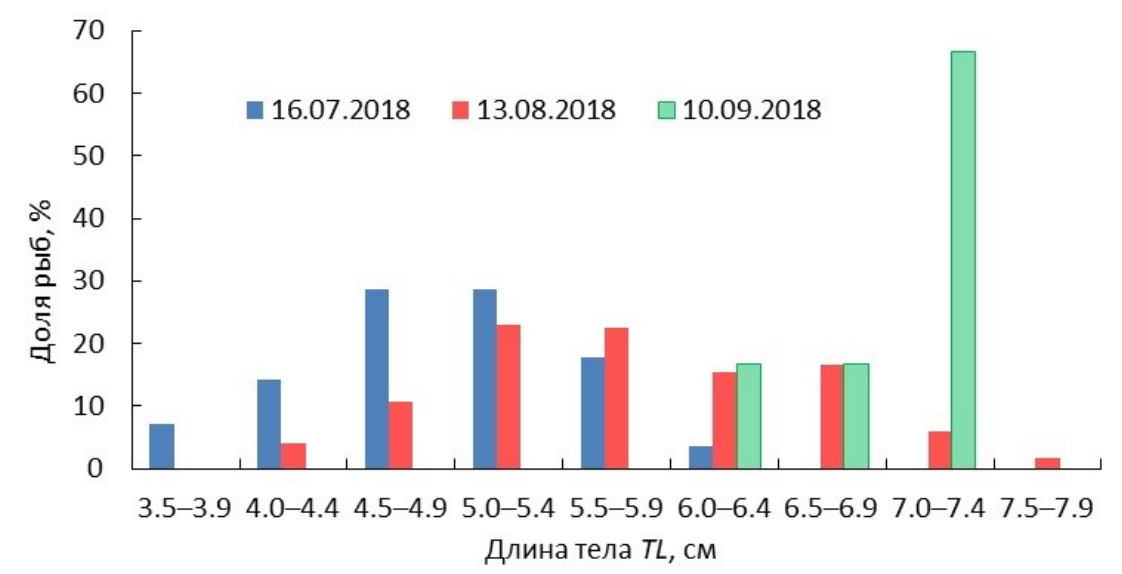

Рис. 2. Размерный состав сеголеток атлантической трески в губе Зеленецкая в 2018 г. in 2018

Fig. 2. Dimensional composition Atlantic cod juveniles in the Zelenetskaya Bay

В июле длина сеголеток сайды варьировала от 2.5 до 7.4 см. В августе появились особи длиной от 7.0 до 9.4 см, в сентябре отмечены единичные экземпляры от 5.0 до 7.4 см (рис. 3). Таким образом, по сравнению с треской, в первые месяцы молодь сайды имеет меньшие размеры, а к середине августа появляются особи свыше 8 см. 


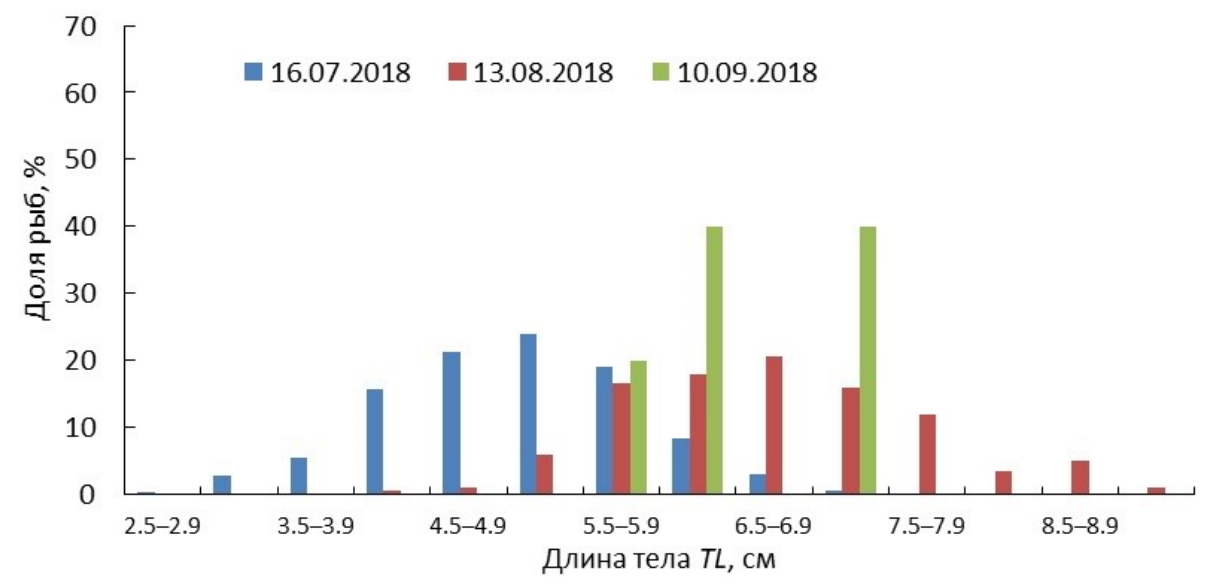

Рис. 3. Размерный состав сеголеток сайды в губе Зеленецкая в 2018 г.

Fig. 3. Dimensional composition pollock juveniles in the Zelenetskaya Bay in 2018

В губе Зеленецкая в литорально-сублиторальной зоне с июля по август месячная продукция сеголеток трески рассчитана в 57.98 г при суточной удельной продукции 0.015 (таблица). Для молоди сайды в этот период исследования месячная продукция выше и составила 702.14 г (при $C=0.042$ ). С августа по сентябрь у трески происходит увеличение удельной скорости роста массы $\left(q_{\mathrm{w}}=1.08\right)$ за счет этого месячная продукция составила 130.83 г, у сайды она снижается до 114.71 г (при $C=0.011)$, несмотря на то, что удельная скорость роста массы на протяжении всего исследования была выше чем у трески.

\section{Продукционные показатели исследуемых видов рыб Production indicators of the studied fish species}

\begin{tabular}{|c|c|c|c|c|c|c|c|c|}
\hline \multirow[b]{2}{*}{ Период } & \multicolumn{4}{|c|}{ Треска } & \multicolumn{4}{|c|}{ Сайда } \\
\hline & $\begin{array}{c}P, \\
\text { г/сут. }\end{array}$ & $\begin{array}{c}q_{\mathrm{w}} \\
1 / \text { cyт. }\end{array}$ & $\begin{array}{c}C, \\
1 / \text { сут. }\end{array}$ & $\begin{array}{c}P_{\mathrm{s}}, \\
\text { Г/Mec. }\end{array}$ & $\begin{array}{c}P, \\
\text { г/сут. }\end{array}$ & $\begin{array}{c}q_{\mathrm{w}}, \\
1 / \text { cyт. }\end{array}$ & $\begin{array}{c}C, \\
1 / \text { сут. }\end{array}$ & $\begin{array}{c}P_{\mathrm{s}}, \\
\Gamma / \mathrm{Mec} .\end{array}$ \\
\hline $607-$ & 2.14 & 0.41 & 0.015 & 57.98 & 26.0 & 1.32 & 0.042 & 702.14 \\
\hline & 4.85 & 1.08 & 0.036 & 130.83 & 4.2 & 0.94 & 0.011 & 114.71 \\
\hline
\end{tabular}

Установлено, что максимальная суточная продукция, составляющая 26 г/сут., отмечена у сеголеток сайды из губы Зеленецкая с июля по август, а к сентябрю она снижается до 4.2 г/сут. (таблица). Для молоди трески в исследуемой акватории этот показатель изменялся от 2.14 до 4.85 г/сут.

Заключение. В результате расчета продукции сообществ рыб в губах Восточного Мурмана установлено, что продукционные показатели сеголеток трески увеличиваются с июля по сентябрь. Для сеголеток сайды продукция к сентябрю снижается, а максимальна с июля по август. Удельная суточная продукция исследуемых видов рыб изменялась в пределах от 0.011 до 0.042 . 
Автор выражает искреннюю благодарность О.Ю. Кудрявцевой и сотрудникам лаборатории альгологии ММБИ РАН за помощь при сборе материала, Н.В. Колпакову за ценные советы и методики расчета, Л.И. Карамушко за обсуждение полученных результатов.

\section{Литература}

Алимов А.Ф., Макарова Г.Е., Максимович Н.В. Методы расчета продукции // Методы изучения двустворчатых моллюсков. Л.: Изд-во АН СССР, 1990. C. $179-195$.

Бондарев O.B. Питание и межвидовые отношения сеголеток трески и сайды в летний период 2012 года в губе Зеленецкая // Исследования экосистем морей Арктики: Матер. XXXV конф. молодых ученых ММБИ КНЦ РАН, посвященной Году экологии в России. Мурманск: Изд. ММБИ КНЦ РАН, 2017. С. 19-24.

Бондарев O.B. Размерно-возрастные характеристики молоди трески Gadus morhua Linnaeus, 1958 и сайды Pollachius virens (Linnaeus, 1958) в прибрежной зоне Баренцева моря в июле 2018 года // Тр. Кольского науч. центра РАН. 2020. T. 4(11). Сер. Океанология. Вып. 7. С. 12-17.

Заика В.Е. Сравнительная продуктивность гидробионтов. Киев: Наук. думка, 1983. $208 \mathrm{c}$

Ихтиофауна прибрежной зоны губ Восточного Мурмана (Ярнышная, Зеленецкая) в летний период 2013 г. / К.И. Ким, О.В. Бондарев, О.Ю. Кудрявцева, C.C. Малавенда // Проблемы Арктического региона: Матер. XIV Междунар. науч. конф. студентов и аспирантов. Т. II. Мурманск: Изд. ММБИ КНЦ РАН, 2014. C. $84-85$.

Камшилов М.М.. Миронова Н.В. Питание мальков тресков рыб пресноводными ракообразными // Докл. АН CCCP. 1950. T. LXXIII, № 5. C. 1097-1099.

Колпаков Н.В. К оценке продукции микронектона эстуариев залива Петра Великого // Изв. ТИНРО. 2010. Т. 162. С. 139-165.

Колпаков Н.В. Продукция рыб в эстуариях Приморья // Изв. ТИНРО. 2016. T. 184. C. 3-22.

Колпаков Н.В. Эстуарные экосистемы северо-западной части Японского моря: структурно-функциональная организация и биоресурсы. Владивосток: Изд-во ТИНРО-Центра, 2018. 428 с.

Кудрявиева О.Ю. Структура прибрежных сообществ молоди рыб в губах Дальнезеленецкая и Ярнышная Баренцева моря // Арктическое морское природопользование в XXI веке - современный баланс научных традиций и инноваций (к 80-летию ММБИ КНЦ РАН): Тез. докл. Междунар. науч. конф. Апатиты: Изд-во КНЦ РАН, 2015. С. 119-121.

Кудрявиева О.Ю. Новые поимки северного пятиусого налима Ciliata septentrionalis (Lotidae) в Баренцевом море // Вопросы ихтиологии. 2017. T. 57, № 4. C. 472-474.

Кудрявиева О.Ю. Структура прибрежных сообществ рыб в губах Ярнышная и Зеленецкая (Восточный Мурман) // Вопросы ихтиологии. 2018. Т. 58, № 4. С. 428-438.

Кудрявиева О.Ю. Характеристика прибрежных сообществ рыб в губах Восточного Мурмана в летне-осенний период 2018 года // Тр. Кольского науч. центра РАН. 2019. Т. 3(10). Сер. Океанология. Вып. 6. С. 22-35.

Кудрявцева Е.О., Кудрявиева О.Ю. Особенности питания сеголеток трески Gadus morhua и сайды Pollachius virens (Gadidae) в губах Восточного Мурмана 
в летний период 2015 г. // Флора и фауна урбанизированных территорий в высоких широтах: Матер. Междунар. науч.-практ. конф. Мурманск: Изд. Мурм. аркт. гос. ун-та, 2017. С. 51-59.

Максимович Н.В., Погребов В.В. Анализ количественных гидробиологических материалов. Л.: Изд-во Ленингр. гос. ун-та, 1986. 96 с.

Миронова Н.В. Веслоногие раки подотряда Наappacticoida как пища молоди тресковых рыб // Докл. АН СССР. 1951. Т. 79, № 5. С. 891-894.

Миронова Н.В. Питание и рост молоди тресковых рыб в прибрежной зоне Восточного Мурмана. М.; Л.: Изд-во АН СССР, 1956. 100 с.

Миронова Н.В. Биология и промысел сайды // Тр. Мурм. биол. ст. АН CCCP. 1957. T. 3. C. 114-129.

Основные результаты исследований лаборатории ихтиологии ММБИ РАН в морях Арктики в 2015-2019 гг. / О.В. Карамушко, Н.Г. Журавлева, Л.И. Карамушко и др. // Тр. Кольского науч. центра РАН. 2020. Т. 4(11). Сер. Океанология. Вып. 7. С. 84-108.

Представители ихтиофауны в прибрежных зонах губ Ярнышная и Зеленецкая в летний период в 2013 и 2014 гг. / О.В. Бондарев, К.И. Ким, C.C. Малавенда, О.Ю. Кудрявцева // Проблемы Арктического региона: Тез. докл. XV Междунар. науч. конф. студентов и аспирантов (г. Мурманск, 14 мая 2015 г.). Ростов н/Д.: Изд-во ЮНЦ РАН, 2015. С. 70-71.

Расхожева Е.В. Закономерности формирования продукции в популяциях атлантической трески Gadus morhua Linnaeus, 1758 и Gadus morhua marisalbi Derjugin, 1920 Баренцева и Белого морей // Современные проблемы гидроэкологии: Тез. докл. 4-й Междунар. науч. конф., посвященной памяти проф. Г.Г. Винберга (11-15 октября 2010 г., Россия, Санкт-Петербург). СПб.: Русская коллекция, 2010. C. 148.

Расхожева Е.В. Динамика продукционных характеристик сайки Boreogadus saida (Gadidae) в Баренцевом море // Вопросы ихтиологии. 2018. Т. 58, № 5. C. 599-607.

Чугунова Н.И. Сравнительные данные по росту молодой трески из прибрежных районов Мурмана в различные годы // Тр. Мурм. мор. биол. ин-та АН СССР. 1967. Вып. 15(19). С. 44-53.

Чумаевская-Световидова Е.В. Видовой состав рыб в районе Мурманской биологической станции // Тр. Мурм. биол. ст. АН СССР. 1955. Т. 2. С. 5-11.

Estuarine production of resident and nursery fish species: Conditioning by drought events? / M. Dolbeth, F. Martinho, I. Viegas et al. // Estuarine. Coastal and Shelf Sci. 2008. Vol. 78, iss. 1. P. 51-60.

DOI: $10.37614 / 2307-5252.2021 .3 .9 .003$

УДК 556.06 (282.256.1)

\title{
А.С. Булавина
}

Мурманский морской биологический институт РАН, г. Мурманск, Россия

\section{МОДЕЛИРОВАНИЕ СТОКА РЕКИ ОБЬ ПРИ ИЗМЕНЕНИИ КЛИМАТА}

\author{
Аннотация \\ Рассмотрены три сценария изменения климата водосборного бассейна Оби \\ в 2021-2050 гг. и их влияние на объем стока реки в замыкающем створе. Показано,
}


что при сохранении тенденций изменения метеорологических характеристик, начавшихся в 1970-х гг., или при их синхронной смене, объем стока р. Обь не будет претерпевать направленных изменений.

Ключевые слова: речной сток, река Обь, прогноз речного стока.

\title{
A.S. Bulavina
}

Murmansk Marine Biological Institute RAS, Murmansk, Russia

MODELLING OF THE OB RIVER RUNOFF UNDER CLIMAT CHANGE

\begin{abstract}
Modelling of the $\mathrm{Ob}$ river runoff under changing climatic conditions has been carried out. Three scenarios of climate change in the Ob river catchment area in 2021-2050 are proposed. It is shown that if the trends of changes in meteorological characteristics that began in the $70^{\text {s }}$ of the $\mathrm{XX}$ century continue, or if they change synchronously, the $\mathrm{Ob}$ river discharge will not undergo significant directional changes.
\end{abstract}

Keywords: river runoff, Ob river, runoff predict.

Введение. Обь - одна из крупнейших рек России и мира. Она обеспечивает более 30 \% речного стока в Карское море. Колебания стока Оби оказывают существенное влияние на гидрологическое и экологическое состояние моря. Объем поступающих в Карское море речных вод влияет на циркуляцию вод в море, а по некоторым оценкам и во всем Арктическом бассейне (Broecker, 1997; Кулаков, 2012). Сток Оби является для экосистемы Карского моря значимым источником разнообразных загрязняющих веществ, в том числе техногенных радионуклидов и нефтепродуктов. Вовлечение участков реки и прилегающей акватории Карского моря в хозяйственную деятельность и в сферу рекреации определяет необходимость научного исследования закономерностей природных процессов Оби как фундаментальной основы устойчивого природопользования (Ильин и др., 2015). Поэтому прогноз изменений объема стока реки является актуальной научной задачей.

Изучать колебания речного стока и делать прогноз его изменений невозможно без оценки действия климатических факторов. Ранее нами был предложен метод реконструкции стока р. Обь по данным о количестве осадков и температуре воздуха на водосборе реки (Булавина, 2020). Реконструированный ряд с высокой точностью воспроизвел многолетние тенденции измеренных средних расходов воды p. Обь. По степени соответствия реконструированных и фактических данных были сделаны выводы о целесообразности применения разработанного метода реконструкции для прогнозных оценок. 
Цель настоящей работы - адаптировать предложенный метод для прогноза изменений стока Оби при сохранении текущих климатических тенденций и в случае наступления альтернативных сценариев изменения климата.

Материал и методы. Метод реконструкции стока р. Обь в замыкающем створе (гидрологический пост “Салехард”), представленный в работе А.С. Булавиной (2020), заключался в поиске оптимальной регрессионной зависимости расходов воды от колебаний метеорологических параметров на отдельных участках водосборного бассейна. Остановимся на ключевых моментах этого поиска.

Водосборный бассейн Оби является одним из крупнейших в мире. Изменения характеристик климата в разных частях бассейна могут иметь разнонаправленный характер. Это затрудняет выявление значимых трендов метеорологических параметров для территории всего бассейна, а также корреляций между ними и объемом стока реки. Поэтому бассейн Оби был поделен на ряд подбассейнов, климат каждого из которых и его влияние на сток реки рассматривали отдельно. Были выделены четыре подбассейна: Иртыш (за исключением водосборных бассейнов Тобола и Ишима), Тобол, Ишим, верхняя и средняя Обь.

Данные метеорологических наблюдений получены из электронной базы данных Всероссийского научно-исследовательского института гидрометеорологической информации - Мирового центра данных (г. Обнинск, Россия; http://meteo.ru/data/158-total-precipitation\#описаниемассива-данных; http://meteo.ru/data/162-temperature-precipitation\#описаниемассива-данных). Были отобраны данные о средних месячных суммах жидких и твердых осадков и ежемесячные данные о температуре воздуха за доступный период наблюдений (с 1936 по 2015 гг.). Для вычисления средних характеристик метеорологических параметров на территориях подбассейнов в качестве расчетного был использован метод естественной окрестности (полигонов Тиссена). По результатам исследований М.Ю. Крюковой и Т.Е. Симакиной (2018), при интерполяции метеорологических данных этот метод дает наиболее достоверные результаты. Из открытой электронной базы “А Regional, Electronic, Hydrographic Data Network For the Arctic Region" (http://www.r-arcticnet. sr.unh.edu/v4.0/Tiles/arctic10.html) были взяты данные гидрологического поста “Салехард” о средних годовых (с 1936 по 2015 гг.) и месячных расходах воды (с 1936 по 1999 гг.).

Анализ корреляционных связей между расходами воды и метеорологическими параметрами позволил определить наиболее значимые из них. Благодаря выделению частных подбассейнов, удалось также выявить локальные зоны преобладающего влияния различных метеорологических параметров на сток нижней Оби. Были составлены различные варианты регрессионных зависимостей между значимыми 
прогностическими метеорологическими характеристиками (предикторами) и расходами воды в замыкающем створе р. Обь. Для каждого полугодия была выбрана функция регрессии, описывающая характер связи между параметрами наилучшим образом. Для холодного полугодия (с ноября по апрель) оптимальной оказалась модель регрессии с двумя переменными, для теплого полугодия (с мая по октябрь) - с пятью переменными. Oбе регрессионные модели значимы по F-критерию, и значимость полученных коэффициентов уравнений регрессии подтверждается по t-критерию. Регрессионные модели хорошо воспроизводят многолетние тренды измеренных средних расходов воды. Они могут быть использованы для прогноза многолетней изменчивости стока Оби при изменении климата.

Межгодовая изменчивость метеорологических параметров практически не поддается моделированию вследствие нелинейности климатических процессов. Моделирование средних климатических характеристик на длительных временных отрезках обладает большей достоверностью, так как может надежно опереться на статистические и вероятностные характеристики метеорологических величин. Средние, дисперсии, функции распределения повторяемости, интенсивности и продолжительности процессов, вероятности наступления тех или иных событий проявляют стабильность на длительных отрезках времени. Таким образом, точечные долгосрочные климатические прогнозы надежнее краткосрочных.

Длительность доступных рядов инструментальных метеорологических наблюдений в бассейне Оби едва достигла 80 лет. И хотя ряды длительностью более 60 лет в метеорологической практике считаются достаточными для статистических расчетов, недоучет долгопериодных колебаний и вторжение неизвестных процессов в полученную вероятностную картину могут снижать точность прогноза.

Одним из самых простых способов прогноза климатических изменений является экстраполяция современных трендов и циклов изменений метеорологических характеристик. Экстраполяционные методы являются одними из самых распространенных и наиболее разработанных среди всей совокупности методов прогнозирования, однако степень достоверности такого рода прогнозов при описании развития природных процессов всегда неопределенная. Она зависит от того, насколько выбранная математическая функция прогноза соответствует характеру изучаемого природного явления. В связи с этим при статистическом анализе тенденций и экстраполировании необходимо сформулировать одну или несколько гипотез о развитии прогнозируемого процесса и, исходя из них, определить факторы, стимулирующие и препятствующие его развитию, а также допустимую дальность экстраполяции. 
Современные климатические изменения, приводящие к флуктуациям речного стока, могут быть вызваны рядом фундаментальных причин, определение которых остается актуальным до настоящего времени. Изучение этого вопроса идет в двух генеральных направлениях. Сторонники первого направления сосредоточены на поиске связи между климатическими изменениями и деятельностью человека. Сторонники второго направления считают, что изменение климата связано с естественными циклическими процессами на планете или за ее пределами. Опираясь на вышеуказанные позиции, были рассмотрены изменения стока р. Обь при изменении климата водосборного бассейна по трем сценариям.

Результаты и обсуждение. Основным источником питания Оби являются атмосферные осадки (Алешина, Гефке, 2019). Количество осадков на водосборе Оби в ХХ веке имело слабую тенденцию к увеличению, но статистическая значимость тренда не подтверждается (Berezovskaya et al., 2004). С середины 1970-х годов средняя годовая температура на водосборе Оби росла со скоростью $0.3{ }^{\circ} \mathrm{C} / 10$ лет (Булавина, 2020). Несмотря на это, сток Оби в XX веке не претерпевал направленных изменений. Отмечено лишь перераспределение стока внутри года при постоянстве среднегодовых расходов воды (Агафонов, 2010). Однако при сохранении наметившихся тенденций изменения климата они могут отразиться и на среднем годовом стоке реки.

При экстраполяции климатических тенденций в водосборном бассейне Оби в качестве основной была принята гипотеза о линейном характере изменения изучаемых метеорологических характеристик на ограниченных временных отрезках.

Сценарий I исходит из гипотезы преобладающего влияния на климат антропогенного воздействия и предполагает сохранение направления и величины трендов всех метеорологических характеристик. Можно ожидать усиления наметившихся тенденций ввиду увеличения антропогенного воздействия, но в сценарии I оно будет принято постоянным.

Дальность экстраполяции будет ограничена временным отрезком до достижения таких изменений климата, при которых закономерности функционирования климатической системы планеты не преобразуются коренным образом. Определить величину этого временного отрезка практически невозможно, поэтому дальность экстраполяции ограничим стандартным климатическим периодом в 30 лет.

Сценарии II и III исходят из гипотезы преобладающего влияния естественных разнопериодных колебаний климата. Многолетние колебания температуры воздуха принято связывать с циклами солнечной активности с периодами около 11, 22, 33, 90 лет. Так как каждый цикл имеет восходящую и нисходящую фазы, то линейное увеличение или 
уменьшение значений температуры следует ожидать на отрезках, равных половинам циклов солнечной активности. Поэтому экстраполировать таким образом можно не более, чем на 45 лет.

Фаза направленных изменений температуры воздуха на водосборе Оби, начавшаяся в 1970-х гг., длится уже около 50 лет. Она может быть связана с квазидевяностолетним циклом солнечной активности. В таком случае в настоящее время график многолетнего хода температуры предположительно подошел к точке экстремума или уже достиг ее. Следовательно, можно ожидать смены тренда на противоположный.

Изменение количества осадков на водосборе Оби в доступный период инструментальных наблюдений (1936-2015 гг.) характеризуется слабой тенденцией к увеличению. Значимых изменений количества осадков с наступлением периода повышения температуры воздуха в 1970-х гг. не наблюдалось. Вероятно, изменение количества осадков на исследуемой территории обусловлено другими климатическими процессами, цикличность которых в доступный период наблюдений не очевидна либо отсутствует. Исходя из этого, можно предполагать как сохранение тенденций в изменении количества осадков, так и смену их направления.

Исходя из гипотезы о линейном характере изменения метеорологических характеристик на прогнозируемых временных отрезках, для прогноза был использован метод линейной экстраполяции. Он заключается в том, что прогнозные величины определяются на основе среднего прироста (уменьшения) исследуемого показателя за определенный период времени. В качестве опорных периодов для экстраполяции были использованы периоды установления современных трендов: с 1970 по 2015 гг. для температуры воздуха, с 1936 по 2015 гг. для количества осадков.

Были определены значения трендов метеорологических характеристик на территории водосбора Оби в опорные периоды и прогнозные средние значения этих характеристик в следующем климатическом периоде (2021-2050 гг.) по трем сценариям (таблица). Сценарий I предполагает сохранение текущих величин и направлений трендов температуры воздуха и количества осадков, сценарий II - сохранение величины тренда температуры воздуха, но изменение его направления, и сохранение тенденций изменения количества осадков, сценарий III - сохранение величин трендов температуры воздуха и количества осадков, но изменение их направлений.

В регрессионную модель были введены прогнозные величины метеорологических характеристик и рассчитан средний объем стока p. Обь по трем климатическим сценариям (рисунок).

Тенденции изменения температуры воздуха и количества осадков, рассчитанные как средние величины для больших площадей, не всегда могут объяснить изменчивость гидрологических характеристик. Водосбор Оби имеет сложное ландшафтное строение. Влияние не 
атмосферных факторов играет большую роль в формировании стока p. Обь. Ландшафтная дифференциация водосборного бассейна создает различия в значимости метеорологических характеристик для разных его участков.

Прогнозные значения

метеорологических характеристик на водосборе р. Обь Forecast values of meteorological characteristics in the catchment area of the $\mathrm{Ob}$ river

\begin{tabular}{|c|c|c|c|c|c|c|}
\hline \multirow[b]{3}{*}{ Год } & \multicolumn{6}{|c|}{ Предиктор } \\
\hline & \multicolumn{2}{|c|}{ Холодное полугодие } & \multicolumn{2}{|c|}{ Теплое полугодие } & \multirow[b]{2}{*}{$\mid \begin{array}{c}\text { Количество } \\
\text { осадков, } \\
\text { мм }\end{array}$} & \multirow[b]{2}{*}{$\begin{array}{c}\text { Средняя } \\
\text { температура } \\
\text { воздуха, }{ }^{\circ} \mathrm{C}\end{array}$} \\
\hline & $\begin{array}{l}\text { Количество } \\
\text { твердых } \\
\text { осадков, мм }\end{array}$ & \begin{tabular}{|c|} 
Средняя \\
температура \\
воздуха, ${ }^{\circ} \mathrm{C}$ \\
\end{tabular} & $\begin{array}{c}\text { Количество } \\
\text { осадков, } \\
\text { мм }\end{array}$ & \begin{tabular}{|c|} 
Средняя \\
температура \\
воздуха, \\
\end{tabular} & & \\
\hline & \multicolumn{6}{|c|}{ Сценарий I } \\
\hline 2030 & 137.9 & -8.2 & 333.0 & 13.8 & 535.7 & 2.5 \\
\hline 2040 & 139.0 & -7.8 & 334.4 & 14.2 & 541.2 & 2.8 \\
\hline 2050 & 140.1 & -7.4 & 335.8 & 14.5 & 546.8 & 3.1 \\
\hline \multicolumn{7}{|c|}{ Сценарий II } \\
\hline 2030 & 137.9 & -9.6 & 333.0 & 13.2 & 535.7 & 1.9 \\
\hline 2040 & 139.0 & -10.0 & 334.4 & 12.8 & 541.3 & 1.6 \\
\hline 2050 & 140.1 & -10.5 & 335.8 & 12.5 & 546.8 & 1.3 \\
\hline \multicolumn{7}{|c|}{ Сценарий III } \\
\hline 2030 & 135.8 & -9.6 & 330.2 & 13.2 & 518.6 & 1.9 \\
\hline 2040 & 134.7 & -10.0 & 328.8 & 12.8 & 513.1 & 1.6 \\
\hline 2050 & 133.6 & -10.5 & 327.4 & 12.5 & 507.6 & 1.3 \\
\hline
\end{tabular}

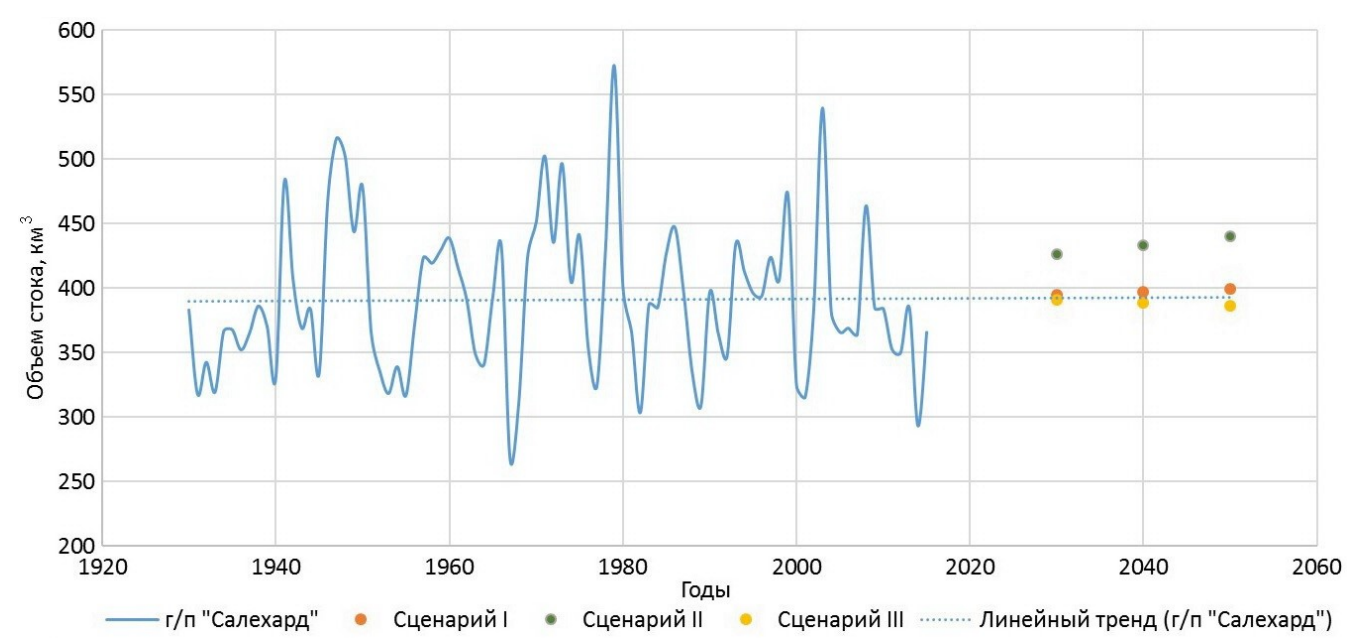

Прогнозные величины объема стока р. Обь (гидрологический пост “Салехард”) при изменении климата

Forecast values of the flow of the Ob river (Salekhard) under climate change

Благодаря делению водосбора Оби на подбассейны, были установлены области преобладающего влияния различных метеорологических 
характеристик на сток реки в замыкающем створе. При сценарном моделировании изменений стока были учтены пространственно-временные неоднородности изменений климата водосборного бассейна Оби. Регрессионная модель расходов воды в створе гидрологического поста “Салехард” основана на отдельном учете колебаний метеорологических параметров в подбассейнах Ишима, Тобола, Иртыша, верхней и средней Оби и различий в формировании речного стока в теплое и холодное полугодие (Булавина, 2020).

Согласно расчетам, объем стока Оби будет стабилен при изменении климата по сценариям I и III. Оба этих сценария предполагают компенсацию возрастающей или убывающей температуры воздуха увеличением или уменьшением количества осадков. С начала 1970-х годов на территории бассейна р. Обь наблюдался интенсивный рост температуры воздуха, в то время как количество осадков не претерпевало статистически значимых изменений. Лежащие вблизи линии многолетнего тренда результаты моделирования объема стока Оби при климатических изменениях по сценариям I и III свидетельствуют о том, что не имеющее статистической значимости изменение количества осадков на территории водосборного бассейна реки способно компенсировать интенсивное значимое изменение температуры воздуха на этой территории. Причинами этому могут быть описанные выше ландшафтная неоднородность водосборного бассейна Оби и пространственновременная изменчивость характеристик климата.

Обь имеет преимущественно снеговое питание. Более 50 \% питания реки приходится на снег, 20-25\% - на дождевое и грунтовое питание (Алешина, Гефке, 2019). Поэтому особенно важны для формирования стока области образования массивных снегозапасов. Такая область расположена в подбассейне верхней и средней Оби (Попова и др., 2010; Булавина, 2020), и именно в этой области тенденции изменения метеорологических характеристик отличаются от таковых в остальных подбассейнах.

Скорость роста средней годовой температуры воздуха в выделенных подбассейнах была практически идентична, статистически значима, и составляла $0.33-0.34{ }^{\circ} \mathrm{C} / 10$ лет. Однако рост средней годовой температуры в подбассейнах Иртыша, Ишима и Тобола происходил преимущественно за счет роста температуры в холодное полугодие, а в бассейне верхней и средней Оби - в основном за счет роста температуры в теплое полугодие.

Изменения температуры воздуха в различные сезоны года по-разному влияют на свойства подстилающей поверхности. Снег, выпадающий на мокрую промерзшую почву, не влияет на питание подземных вод, так как при весеннем снеготаянии вода не имеет возможности просочиться вглубь почвы. Если снег выпадает на талую или промерзшую сухую почву, то в нее при весеннем снеготаянии 
обильно просачиваются воды. Улучшение просыхания почвы в теплое полугодие может способствовать питанию грунтовых вод и поддержанию водности реки за счет быстрого выведения значительного количества влаги из области интенсивного испарения (Комлев, 2002). Объем влаги, дополнительно запасенной в грунтах весной, может компенсировать увеличившиеся затраты влаги на испарение летом и осенью. Так как подбассейн верхней и средней Оби является важнейшей областью накопления снегозапасов, то проницаемость грунтов в этой области имеет большое значение для формирования стока.

На территориях подбассейнов наблюдались изменения годового количества осадков с разной скоростью. В подбассейнах Иртыша, Ишима и Тобола среднее годовое количество осадков имело тенденцию к увеличению, в подбассейне верхней и средней Оби - к уменьшению. При этом увеличение количества осадков происходило преимущественно в холодное полугодие, уменьшение - в теплое полугодие. Можно отметить статистически значимое увеличение количества осадков в холодное полугодие в подбассейне Иртыша со скоростью 1.5 мм/год, а это около $2.5 \mathrm{~km}^{3}$ воды ежегодно. Также наблюдалось значимое уменьшение количества осадков в теплое полугодие в подбассейне верхней и средней Оби со скоростью 0.8 мм/год, что уменьшает количество поступающей воды на $0.8 \mathrm{~km}^{3} /$ год. Однако, уменьшение количества осадков в подбассейне верхней и средней Оби в теплое полугодие в совокупности с ростом температуры воздуха может способствовать просыханию грунтов перед наступлением холодов, улучшая условия питания грунтов при весеннем снеготаянии.

Согласно сценарию II, средняя годовая температура воздуха в пределах водосборного бассейна Оби с 2021 по 2050 гг. будет снижаться со скоростью $0.3{ }^{\circ} \mathrm{C} / 10$ лет. Количество осадков на водосборе p. Обь будет незначительно расти при наличии разнонаправленных тенденций в подбассейнах Иртыша, Ишима, Тобола, верхней и средней Оби. По результатам моделирования, объем стока Оби в створе гидрологического поста “Салехард” при таких изменениях климата будет

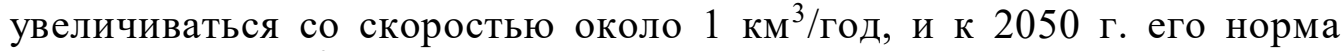
достигнет $430 \mathrm{\kappa m}^{3}$.

Картина временных колебаний метеорологических характеристик в мозаичном пространстве ландшафтно-гидрологических комплексов водосборного бассейна р. Обь чрезвычайно сложна. Отмеченные выше закономерности требуют дополнительного изучения.

Заключение. Получены прогнозные оценки объема стока р. Обь при изменении климата по трем сценариям. Показано, что в течение последних 50 лет тенденции изменения температуры воздуха и количества осадков на водосборе Оби находятся в равновесии и способствуют стабильности объема речного стока. При сохранении современных трендов метеорологических характеристик (сценарий I) или 
при их синхронной смене (сценарий III) сток Оби не будет претерпевать направленных изменений. Увеличение объема стока можно ожидать при реализации климатического сценария II с обратным трендом изменений температуры воздуха и сохранением тенденций изменения количества осадков.

Пространственное и сезонное распределение осадков на водосборе Оби имеет большое значение для формирования речного стока. Разнонаправленные тенденции изменения температуры воздуха и количества осадков в разных по геолого-геоморфологическому строению частях водосбора определяют объем стока Оби. Даже при отсутствии направленных изменений количества осадков на водосборе в целом изменение их количества в локальных областях оказывает заметное влияние на объем стока реки. Необходимо учитывать это при проведении гидрометеорологических исследований.

Работа выполнена в рамках государственного задания.

\section{Литература}

Агафонов Л.И. Сток Оби и его изменения в ХХ столетии // Изв. РАН. Сер. географ. 2010. № 4. С. 68-76.

Алешина Н.И., Гефке И.В. Особенности гидрологического режима верхней Оби для возможности водохозяйственного использования // Междунар. журн. гуманитарных и естественных наук. 2019. Т. 11-2, № 38. C. 57-60. DOI: 10.24411/2500-1000-2019-11751

Булавина A.C. Реконструкция стока реки Обь по данным метеорологических наблюдений // Тр. Кольского науч. центра РАН. 2020. T. 5(11). Сер. Океанология. Вып. 8. С. 17 -27. DOI: 10.37614/2307-5252.2020.11.5

Ильин Г.В., Усягина И.С., Касаткина Н.Е. Геоэкологическое состояние среды морей российского сектора Арктики в условиях современных техногенных нагрузок // Вестн. Кольского науч. центра РАН. 2015. № 2(21). С. 82-93.

Комлев А.М. Закономерности формирования и методы расчета речного стока. Пермь: Изд-во Пермского гос. ун-та, 2002. 163 с.

Крюкова М.Ю., Симакина Т.Е. Оценка методов пространственной интерполяции метеорологических данных // Общество. Среда. Развитие. 2018. № 1. С. 144-151.

Кулаков М.Ю. О новом подходе к моделированию циркуляции вод арктических морей // Проблемы Арктики и Антарктики. 2012. Т. 2, № 92. С. 55-62.

Попова В.В., Шмакин А.Б., Симонов Ю.А. Изменения снегозапасов и жидких осадков и их роль в колебаниях стока крупнейших рек бассейна Северного Ледовитого океана при современном потеплении // Проблемы экологического мониторинга и моделирования экосистем. 2010. Т. 23. С. 109-127.

Berezovskaya S., Yang D., Kane D. Compatibility analysis of precipitation and runoff over the large Siberian watersheds // Geophysical Research Letters. 2004. Vol. 31, № L21502. C. 1-4. DOI: 10.1029/2004GL021277

Broecker W.S. Thermohaline circulation, the Achilles heel of our climate system: will man-made $\mathrm{CO}_{2}$ upset the current balance // Science. 1997. Vol. 278. P. $1582-1588$. 
DOI: 10.37614/2307-5252.2021.3.9.004

УДК 632.15 (470.21)

\title{
Д.А. Валуйская, Г.В. Ильин
}

Мурманский морской биологический институт РАН, г. Мурманск, Россия

\section{ЧЕРНОБЫЛЬСКИЙ СЛЕД В НАЗЕМНЫХ ЭКОСИСТЕМАХ СЕВЕРО-ЕВРОПЕЙСКОГО РЕГИОНА}

\begin{abstract}
Аннотация
Представлен анализ длительных изменений радиоэкологического состояния элементов наземной экосистемы севера европейской части России и Скандинавии, подвергавшихся воздействию атмосфрерных выпадений продуктов аварии Чернобыльской АЭС 35 лет назад. Анализируется состояние объектов, включенных в пищевую сеть населения и формирующих дозу внутреннего облучения жителей Мурманской области. Показан актуальный уровень радиоактивного загрязнения распространенных грибов и ягод лесотундровой зоны. Даются сравнительные оценки эффректов глобальных выпадений радионуклидов на территории Северной Европы.
\end{abstract}

Ключевые слова: техногенные радионуклиды, аэрозоли, дикорастущие ягоды и грибы, рыба, почва.

\section{D.A. Valuyskaya, G.V. Ilyin}

Murmansk Marine Biological Institute RAS, Murmansk, Russian

\section{RADIONUCLIDES IN MARINE AND TERRESTRIAL ECOSYSTEMS OF THE NORTH EUROPEAN REGION}

\begin{abstract}
The paper presents an analysis of the radioecological state of the terrestrial ecosystems in north european part of the Russia, which were exposed to the a products of the Chernobyl accident. The analysis of the state of marine and terrestrial objects included in the food network of the population and forming the dose of internal radiation of the population of the Murmansk region is given. Comparative estimates of the effects of global radionuclide deposition in the North-European territory are given.
\end{abstract}

Keywords: technogenic radionuclides, aerosols, wild berries and mushrooms, fish, soil.

Чернобыльские выпадения 35 лет назад привели к радиационному загрязнению территорий Скандинавского и Кольского полуостровов. Зараженные атмосферные осадки в меньшей степени затронули морские арктические акватории и в основном выпали на территорию суши (Arvela et al., 1990; Техногенные ..., 2005). Загрязнению подверглись почва и растительность. В дальнейшем выпавшие осадки, в том числе смываемые с обширной площади водосборов, оказали влияние на арктическую 
морскую среду - воду, донные осадки и биоту. Наиболее значимый вклад в выпадениях принадлежит радиоизотопу ${ }^{137} \mathrm{Cs}$. Позже, в 2011 г., над территорией Северной Европы были отмечены аэрозоли аварийных выбросов АЭС “Фукусима Дайичи”. Однако значимого воздействия этих выпадений на территорию региона и акваторию Баренцева моря отмечено не было (К оценке ..., 2012; Artificial ..., 2013). Таким образом, современная неравномерность радиоактивного загрязнения наземной среды и вариации дозы внутреннего облучения населения во многом отражают ретроспективные эффекты распространения облака чернобыльских выбросов.

Цель настоящей работы - показать современный уровень радиационного загрязнения дикорастущих грибов и ягод и динамику его изменений по следу выпадений продуктов чернобыльской аварии на севере Европы.

Материалами для работы послужили многолетние экспедиционные и аналитические исследования активности ${ }^{137} \mathrm{Cs}$ в наземных экосистемах, проводимые Мурманским морским биологическим институтом РАН в 2011-2020 гг. на территории Мурманской области, и литературные сведения по загрязнению севера Скандинавии.

Радиометрический анализ проб выполнен в лаборатории ММБИ PAН. Активность ${ }^{137} \mathrm{Cs}$ измерена в счетных образцах на спектрометрах $\boldsymbol{\gamma}$-излучения "InSpector-2000", $\boldsymbol{\gamma}$ - и рентгеновского излучения "b13237" (“Canberra”, США). Спектры проанализированы с помощью программного обеспечения Cenie-2000.

В качестве показательных компонентов экосистемы приняты дикорастущие грибы и ягоды, занимающие наиболее важное место в питании населения. Регулярное потребление этих продуктов населением определяет теоретическую и практическую актуальность данной работы. Пробы биологических образцов и почвы отобраны на нескольких площадках в районах, наиболее посещаемых местным населением при сборе грибов и ягод (рис. 1).

Общий уровень загрязнения северных территорий можно оценить по содержанию техногенного ${ }^{137} \mathrm{Cs}$ в почве (табл. 1). В 1986 году наибольшие количества ${ }^{137} \mathrm{Cs}$ чернобыльского происхождения выпали в финской Лапландии - до 3.6 кБк/ $\mathrm{M}^{2}$. В Мурманской области и Северной Норвегии выпало не более 2.72 и 1.19 кБк/м² соответственно (Arvela et al., 1990; Nedfall ..., 1986; Summary ..., 2002).

После чернобыльских выпадений подробные исследования, позволяющие дать сравнительные оценки загрязнения, были выполнены лишь в 2011-2012 и 2017 гг. Обращает внимание значительная неравномерность концентраций этого элемента на каждой площадке проботбора. В целом можно отметить, что снижение радиоактивного загрязнения почв происходит значительно интенсивнее, чем при естественном распаде. Лишь в отдельных участках Мурманской области 
(район пос. Дальние Зеленцы) и Северной Норвегии (район заповедника Дивидален) еще сохраняется активность, сопоставимая с уровнем 1986 г. (табл. 1).

Рис. 1. Станции отбора проб на Кольском полуострове в 2011-2012,

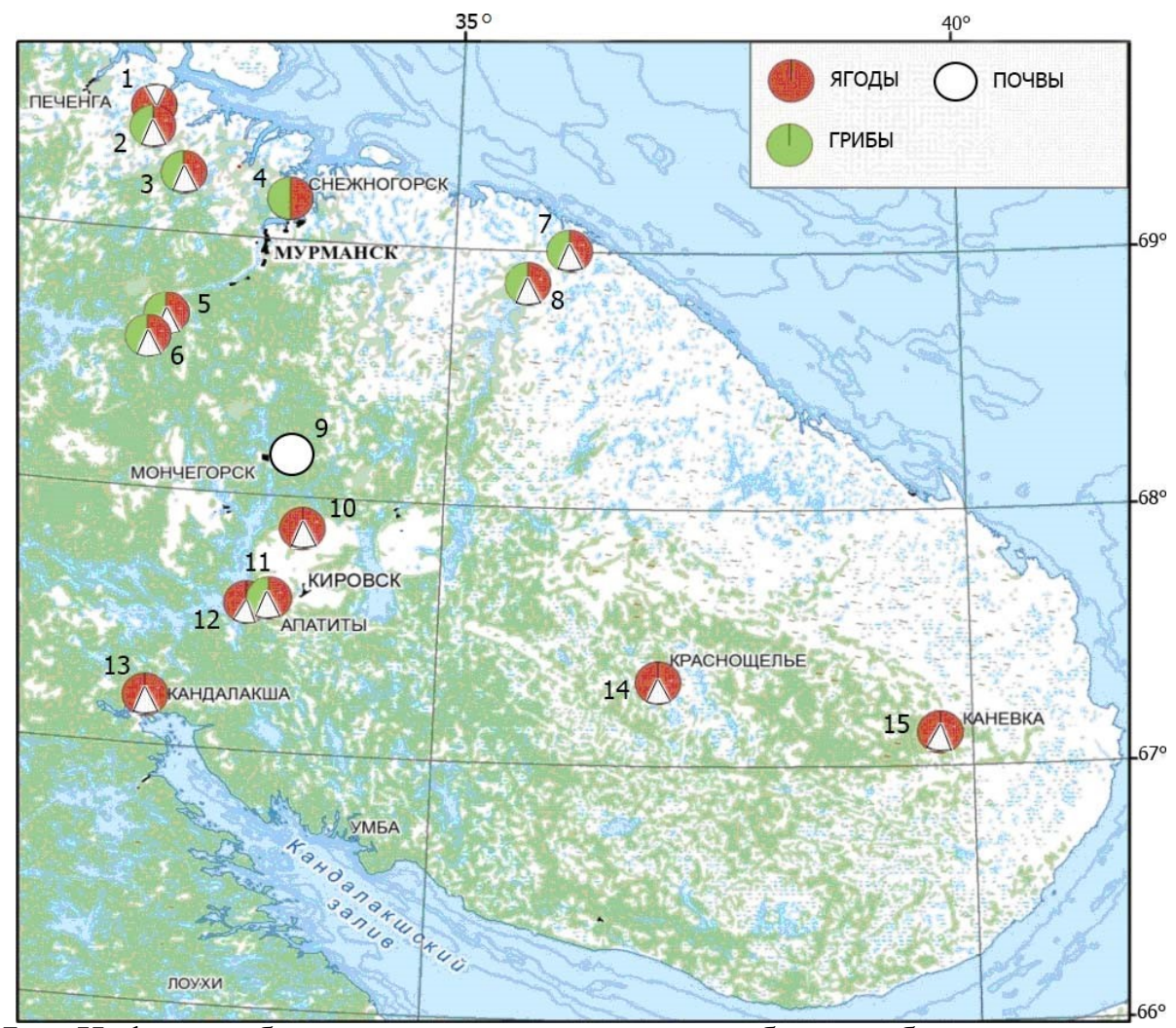

2017 гг. Цифрами обозначены номера площадок отбора проб

Fig. 1. Sampling stations on the Kola Peninsula in 2011-2012, 2017. The numbers indicate the figures of sampling sites

Удельная активность ${ }^{137} \mathrm{Cs}$ в почвах северной части Европы, Бк $/ \mathbf{M}^{2}$

Т а б ли ц а 1 Specific activity of ${ }^{137} \mathrm{Cs}$ in the soils of northern Europe, $\mathrm{Bq} / \mathrm{m}^{2}$

\begin{tabular}{l|c|r|c|c|c|c|c}
\hline \multirow{2}{*}{\multicolumn{1}{c|}{ Район }} & 1986 г. & \multicolumn{3}{c|}{ 2011-2012 гг. } & \multicolumn{3}{c}{2017 г. } \\
\cline { 2 - 9 } & Среднее & Макс. & Мин. & Среднее & Макс. & Мин. & Среднее \\
\hline Лапландия & 3600 & 312 & 275 & 294 & - & - & - \\
Мурманская область & 2720 & 1045 & 149 & 502 & 385 & 13 & 134 \\
Северная Норвегия: & & 1098 & 217 & 528 & - & - & - \\
Дивидален & 1190 & 1098 & 285 & 625 & - & - & - \\
Пасвик & & 354 & 217 & 285 & - & - & -
\end{tabular}

Наиболее интенсивное снижение загрязнения почвы происходит на территории Лапландии и Кольского полуострова, где удельная 
активность ${ }^{137} \mathrm{Cs}$ составляет около $10-15 \%$ от уровня, ожидаемого при естественном распаде этого радиоизотопа. Причиной этого, очевидно, является вымывание радиоцезия почвенными водами в естественные водотоки и водоемы, а также его миграция в нижние горизонты почвенного слоя. В Северной Норвегии самоочищение верхнего слоя почв происходит менее интенсивно. Здесь остаточный уровень загрязнения составляет около 75 \% ожидаемого при естественном распаде.

Исследования дикорастущих грибов и ягод на загрязненных территориях показали, что накопленные в них уровни искусственных радионуклидов даже в первые годы после чернобыльских выпадений оставались много ниже санитарных норм для пищевых продуктов в этих странах. Установлено, что средняя удельная активность ${ }^{137} \mathrm{Cs}$ в съедобных грибах сем. Boletaceae в 1987-1992 гг. составляла для районов Лапландии, Кольского полуострова и Северной Норвегии 1000-2800 Бк/кг сухой массы (Радионуклиды ..,, 1994). В 2011-2012 годах удельная радиоактивность ${ }^{137} \mathrm{Cs}$ во всех пробах ягод и грибов из этих же районов еще более снизилась (табл. 2). Однако при сравнительных оценках наблюдаются четкие территориальные и видовые различия в накоплении радиоактивности. К примеру, наиболее популярный съедобный гриб подосиновик содержал ${ }^{137} \mathrm{Cs} 12-185$ Бк/кг сухой массы, а сыроежка 26-512 Бк/кг сухой массы. Кроме того, прослеживается значительная внутривидовая вариабельность радиоактивности в пределах одной площадки сбора проб. Повышенные концентрации радионуклида отмечали и в условно съедобных грибах (свинушки и горькушки) 35-486 Бк/кг сухой массы. Следует помнить, что обычно масса сухих грибов и ягод составляет 6-14 \% от массы свежих плодов. В среднем содержание сухого вещества может быть оценено для ягод и грибов приблизительно в 10 \%. Самые востребованные населением грибы сем. Boletaceae (подосиновики, подберезовики) накапливают техногенные радионуклиды из окружающей среды более других.

Со времени чернобыльских выпадений загрязнение дикорастущих съедобных грибов снизилось более чем в 10 раз. К настоящему времени, по-видимому, устанавливается колеблющееся равновесие между концентрацией ${ }^{137} \mathrm{Cs}$ в грибах и микровариациями его содержания в почвах. В среднем удельная активность радиоцезия в грибах сем. Boletaceae составляет около 310 Бк/кг сухой массы. При этом санитарные нормы допускают активность 5 кБк/кг в пересчете на сухую массу (СанПиН 2.3.2.1078-01).

Содержание ${ }^{137} \mathrm{Cs}$ в ягодах северных лесотундровых ландшафтов в первые годы после чернобыльских выпадений снизилось в 4-8 раз (табл. 3). 
Т а бли ц а 2

Средняя удельная активность ${ }^{137}$ Cs в популярных съедобных грибах северной части Европы, Бк/кг сухой массы

Table 2

Average specific activity of ${ }^{137} \mathrm{Cs}$ in popular edible mushrooms of northern Europe, Bq/kg d.w.

\begin{tabular}{|c|c|c|c|c|c|c|c|c|}
\hline \multirow{2}{*}{ Район } & \multicolumn{2}{|c|}{ Подосиновик } & \multicolumn{2}{|c|}{ Подберезовик } & \multicolumn{2}{|c|}{ Сыроежка } & \multicolumn{2}{|c|}{ Волнушка } \\
\hline & 2011 г. & 2017 г. & $2011 г$. & 2017 г. & 2011 г. & $2017 \Gamma$ & 2011 г. & $2017 \Gamma$ \\
\hline Лапландия & 70 & - & 397 & - & 271 & - & - & - \\
\hline $\begin{array}{l}\text { Мурманская } \\
\text { область }\end{array}$ & 74 & 141 & 281 & 480 & 279 & 164 & 50 & 264 \\
\hline $\begin{array}{l}\text { Северная } \\
\text { Норвегия: }\end{array}$ & 355 & - & 636 & - & 326 & - & - & - \\
\hline Дивидален & 546 & - & - & - & 177 & - & - & - \\
\hline Пасвик & 163 & - & 636 & - & 474 & - & - & - \\
\hline
\end{tabular}

Средняя удельная активность ${ }^{137} \mathrm{Cs}$ в дикорастущих ягодах

Т аблиц и 3 северной части Европы, Бк/кг сухой массы

Average specific activity of ${ }^{137} \mathrm{Cs}$ in wild berries

Table 3 of northern Europe, Bq/kg d.w.

\begin{tabular}{|c|c|c|c|c|c|c|c|c|c|}
\hline \multirow{2}{*}{ Район } & \multicolumn{3}{|c|}{ Черника } & \multicolumn{3}{|c|}{ Брусника } & \multicolumn{3}{|c|}{ Морошка } \\
\hline & 1989 г. & 2011 г. & 2017 I & .1986 г. & * 2011 г. & 2017 & 1988 г. & ${ }^{*} 2011 \Gamma$ & r. 2017 г. \\
\hline Лапландия & - & 34 & - & - & 19 & - & - & - & - \\
\hline $\begin{array}{l}\text { Мурманская } \\
\text { область }\end{array}$ & 200 & 36 & 53 & 230 & 14 & 20 & 220 & 23 & 170 \\
\hline Северная & - & 47 & - & - & 28 & - & - & - & - \\
\hline Норвегия: & & & & & & & & & \\
\hline Дивидален & - & 28 & - & - & 16 & - & - & - & - \\
\hline Пасвик & - & 65 & - & - & 39 & - & - & - & - \\
\hline
\end{tabular}

*Данные приведены по: Радионуклиды ..., 1994.

К 2011 году и далее к 2017 г. накопление радионуклидов в ягодах относительно стабилизировалось и в течение этих лет варьировало в пределах 30 \%. Среди наиболее востребованных ягод сем. Ericaceae (черника, брусника, голубика) максимальным содержанием ${ }^{137} \mathrm{Cs}$ характеризуется черника, в которой этот радиоизотоп накапливается вдвое больше, чем в бруснике. Низкие концентрации отмечены в голубике, слабо распространенной в полярных ландшафтах ягоды, в среднем 8.5 Бк/кг сухой массы. Содержание ${ }^{137} \mathrm{Cs}$ в ягодах на исследуемой территории может различаться в несколько раз в зависимости от района сбора, однако остается значительно ниже предельно допустимых уровней, принятых в России - 1600 Бк/кг сухой массы (СанПиН 2.3.2.1078-01). Сравнение современных уровней 
накопления ${ }^{137} \mathrm{Cs}$ в грибах и ягодах Мурманской области, в Лапландии (Lehto et al., 2013) и Норвегии (Gwynn ..., 2013) показало, что дикоросы в Северной Финляндии более загрязнены.

На основе полученных данных был проведен расчет внутренней дозы облучения жителей Мурманской области при употреблении ягод и грибов. Для расчета был использован метод, принятый Роспотребнадзором в 2008 г. (МУ 2.6.1.2222-07 ..., 2008). Чтобы избежать неопределенности, которую вносят неточные данные по годовому потреблению продуктов леса, расчеты выполнены для “условного потребления" - 1 кг/год сухой массы. Годовое поступление ${ }^{137} \mathrm{Cs}$ при потреблении грибов составляет 7.5 и 8.5 Бк по данным 2011 и 2017 гг. соответственно. Это составляет лишь $2 \%$ от общего поступления радиоцезия в организм человека с пищей (рис. 2).

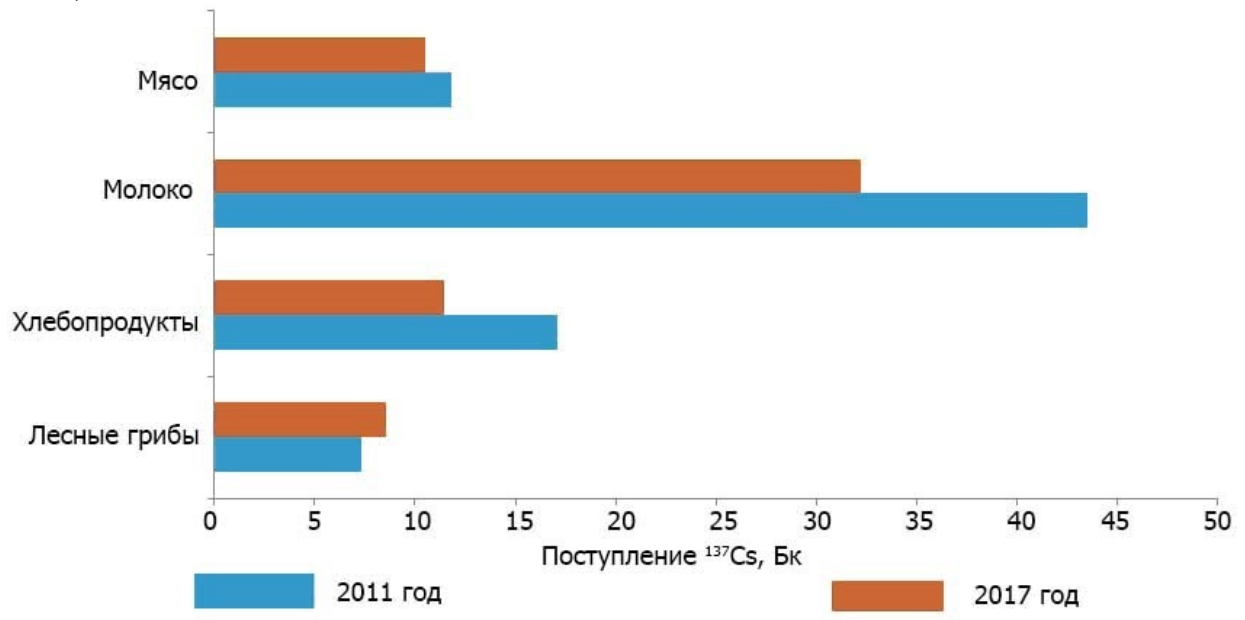

Рис. 2. Годовое поступление ${ }^{137} \mathrm{Cs}$ с пищей в организм человека, проживающего на территории Мурманской области with food

Fig. 2. Annual intake of ${ }^{137} \mathrm{Cs}$ into the human body in the Murmansk region,

Годовая эффективная доза облучения ${ }^{137} \mathrm{Cs}$, получаемая населением Мурманской области при употреблении основных продуктов питания, не превышает 0.002 м3в, что составляет менее $1 \%$ от установленного уровня безопасных дозовых нагрузок (СанПиН 2.6.1.2523-09).

Таким образом, получаемая населением при употреблении в пищу всех видов съедобных грибов доза внутреннего облучения на порядки ниже допустимых санитарных норм (СанПиН 2.6.1.2523-09). Аналогичные закономерности соблюдаются и для дикорастущих ягод, объем потребления которых статистически не определен. Население Северной Финляндии получает несколько большие дозы техногенного облучения, что объясняется повышенным загрязнением территории финской Лапландии после аварии на Чернобыльской АЭС. 
Очевидно, что средняя годовая доза внутреннего облучения населения при употреблении лесных грибов и ягод, как и других сельскохозяйственных продуктов, слабо изменяется от года к году, оставаясь на очень низком уровне (рис. 2). Условия такой нестабильности в постчернобыльский период определятся межпериодной неравномерностью глобальных выпадений техногенных радиоизотопов на территорию северной Скандинавии и Кольского полуострова, служащую водосбором для экосистемы Баренцева моря.

Авторы выражают благодарность за помощь в сборе проб в удаленных восточных районах области (Краснощелье, Каневка, Сосновка) учителю биологии местной общеобразовательной школы М.А. Рочеву.

Работа выполнена по проекту Российского фонда фундаментальных исследований "Радиоактивное загрязнение и вторичные источники антропогенных изотопов в морях Северного Ледовитого океана на рубеже XX-XXI веков” (№ 18-05-60249) в рамках государственного задания.

\section{Литература}

К оценке воздействия аварийных выбросов АЭС “Фукусима-1” на моря Западной Арктики (на примере Баренцева моря) / Г.Г. Матишов, Г.В. Ильин, Н.Е. Касаткина и др. // Докл. РАН. 2012. Т. 446, № 4. С. 448-452.

MУ 2.6.1.2222-07. Прогноз доз облучения населения радионуклидами цезия и стронция при их попадании в окружающую среду. М.: Роспотребнадзор, 2008. 24 c.

Радионуклиды в экосистеме региона Баренцева и Карского морей / Г.Г. Матишов, Д.Г. Матишов, Е. Щипа, К. Риссанен. Апатиты: Изд-во КНЦ PAH, 1994. 235 c.

Техногенные радионуклиды в морях, омывающих Россию / Ю.В. Сивинщев, С.М. Вакуловский, А.П. Васильев и др. М.: ИздАТ, 2005. 624 с.

Artificial radionuclides in surface air in Finland following the Fukushima Dai-ichi nuclear power plant accident / A.-P. Leppänen, A. Mattila, M. Kettunen et al. // J. Environ. Radioactivity. 2013. Vol. 126. P. 273-283.

Arvela H., Markkanen M., Lemmelä H. Mobile survey of environmental gamma radiation and fall-out levels in Finland after the Chernobyl accident // Radiation Protection Dosimetry. 1990. Vol. 3. P. 177-184.

Gwynn J.P., Nalbandyan A., Rudolfsen $G .{ }^{210} \mathrm{Po},{ }^{210} \mathrm{~Pb},{ }^{40} \mathrm{~K}$ and ${ }^{137} \mathrm{Cs}$ in edible wild berries and mushrooms and ingestion doses to man from high consumption rates of these wild foods Original Research Article // J. Environ. Radioactivity. 2013. Vol. 116. P. 34-41.

Lehto J., Vaaramaa K., Leskinen A. ${ }^{137} \mathrm{Cs},{ }^{239,240} \mathrm{Pu}$ and ${ }^{241} \mathrm{Am}$ in boreal forest soil and their transfer into wild mushrooms and berries // J. Environ. Radioactivity. 2013. Vol. 116. P. 124-132.

Nedfall av cesium i Norge etter Tsjernobylulyyken / S. Backe, H. Bjerke, A. Rudjord, F. Ugletveit. Østerås: Statens Inst. Strelehygiene, 1986. № 5. 49 p.

Summary Report. Strålevern Rapport / Norwegian Radiation Protection Authority. JRNEG. Østerås, 2002. № $5.120 \mathrm{p}$. 
DOI: 10.37614/2307-5252.2021.3.9.005

УДК $579.68(268.45)$

\title{
А.В. Ващенко
}

Мурманский морской биологический институт РАН, г. Мурманск, Россия

\section{ОСЕННИЙ БАКТЕРИОПЛАНКТОН ОТКРЫТОЙ И ПРИБРЕЖНОЙ ЧАСТИ БАРЕНЦЕВА МОРЯ}

\section{Аннотация}

Представлены результаты микробиологических исследований, выполненных в октябре 2017 г. в Мотовском заливе и октябре 2020 г. в северо-восточной части Баренцева моря. Установлено, что при сопоставимых значениях численности, биомассы бактериопланктона в открытых водах были несколько выше, чем в прибрежных. Диапазон колебаний численности и биомассы составил,

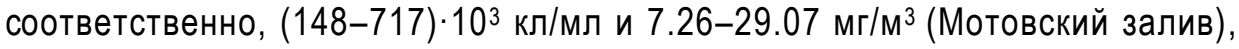

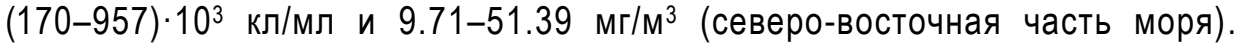
Максимальные значения показателей наблюдались в слое 0-50 м, минимальные в придонном слое районов исследований. Полученные данные позволяют дополнить имеющиеся представления о развитии и распределении баренцевоморского бактериопланктона в осенний сезон.

Ключевые слова: бактериопланктон, Мотовский залив, Баренцево море.

\section{A.V. Vashchenko \\ Murmansk Marine Biological Institute RAS, Murmansk, Russia \\ AUTUMN BACTERIOPLANKTON OF THE OPEN WATERS AND COASTAL PART OF THE BARENTS SEA}

\begin{abstract}
The paper presents the results of microbiological studies carried out in the Motovsky Bay (2017) and the northeastern part of the Barents Sea (2020) in October. It was shown that, with comparable values of abundance, the biomass of bacterioplankton in open waters was slightly higher than in coastal waters. The quantity was 148-717 thousand cells/ml in Motovsky Bay and 170-957 thousand cells/ml in the open water area. The biomass was $7.26-29.07 \mathrm{mg} / \mathrm{m}^{3}$ in Motovsky Bay and $9.71-$ $51.39 \mathrm{mg} / \mathrm{m}^{3}$ in the open water area. The maximum values were in the $0-50 \mathrm{~m}$ layer, the minimum - in the bottom layer in both areas. Those results supplement the existing understanding of bacterioplanktons development and distribution in the Barents Sea in the autumn season.
\end{abstract}

Keywords: bacterioplankton, Motovskiy Bay, the Barents Sea. 
В арктических экосистемах бактериопланктон играет ключевую роль в балансе вещества и энергии. Бактерии минерализуют органическое вещество, образуя соединения биогенных элементов, которые активно ассимилируются фитопланктоном (Экология ..., 1990; Microbial ..., 2008), кроме того они используются в пищу гетеротрофными жгутиконосцами, инфузориями, аппендикуляриями, копеподами и личинками донных организмов (Экология ..., 1990; Vargas, González, 2004). Несмотря на значимость микроорганизмов в трофике морских экосистем, они до сих пор остаются недостаточно изученным компонентом.

Изучение микроорганизмов Баренцева моря имеет длительную историю. Первые упоминания относятся к началу XX века (Исаченко, 1914). Наиболее полно изучены прибрежные районы (Байтаз, 1990; Комплексный ..., 1990; Теплинская, 1990; Байтаз, Байтаз, 1991; Планктон ..., 1997; Байтаз, 1998; Венгер, 2013, 2019 и др.), в то время как труднодоступные высокоширотные области, особенно в осенний период, остаются неисследованными (Бактериопланктон ..., 2017).

Цель данной работы - изучить пространственное распределение количественных характеристик бактериопланктона и его размерноморфологическую структуру в осенний период в прибрежной (Мотовский залив) и открытой части (северо-восток, район Земли Франца-Иосифа) Баренцева моря.

Баренцево море относится к шельфовым арктическим морям. Его важной особенностью является проникновение атлантических вод через западную границу моря (Воды ..., 2016) при одновременном поступлении холодных вод Северного Ледовитого океана с севера по обе стороны Земли Франца-Иосифа (Панченко, 1991). Осенью на северо-востоке Баренцева моря температура воды от небольших положительных значений на поверхности понижается примерно до $-1.7{ }^{\circ} \mathrm{C}$ у дна (Добровольский, Залогин, 1982).

Мотовский залив относится к открытому типу, где сохраняется типично морской термохалинный режим (Перцева, 1939).

Материал и методы. Сбор материала осуществлялся в ходе экспедиций Института на НИС “Дальние Зеленцы” 29, 30 октября 2017 г. в Мотовском заливе (три станции) и 9, 10 октября 2020 г. в открытой северо-восточной части Баренцева моря (три станции, между Землей Франца-Иосифа и Новой Землей) (рис. 1). Пробы отбирали по стандартным горизонтам $(0,10,25,50,100$ м, дно) батометром Нискина.

Измерения основных океанографических параметров морской среды проводились методом CTD-профилирования с помощью зонда SBE 19plus V2 SeaCAT.

Численность и биомассу бактериопланктона определяли методом прямого счета с использованием ядерных фильтров (диаметр пор 0.2 мкм) и красителя DAPI (Porter, Freig, 1980). Препараты просматривали 
под эпифлуоресцентным микроскопом Olympus BX53 при ув. 1000. Для анализа линейных размеров клеток и их численности применяли программное обеспечение CellSensStandart. Помимо этого, определяли размерно-морфологический состав бактериопланктона. При установлении корреляционных зависимостей между параметрами был использован ранговый коэффициент корреляции Спирмена и $U$-критерий МаннаУитни для уровня значимости $p \leq 0.05$.

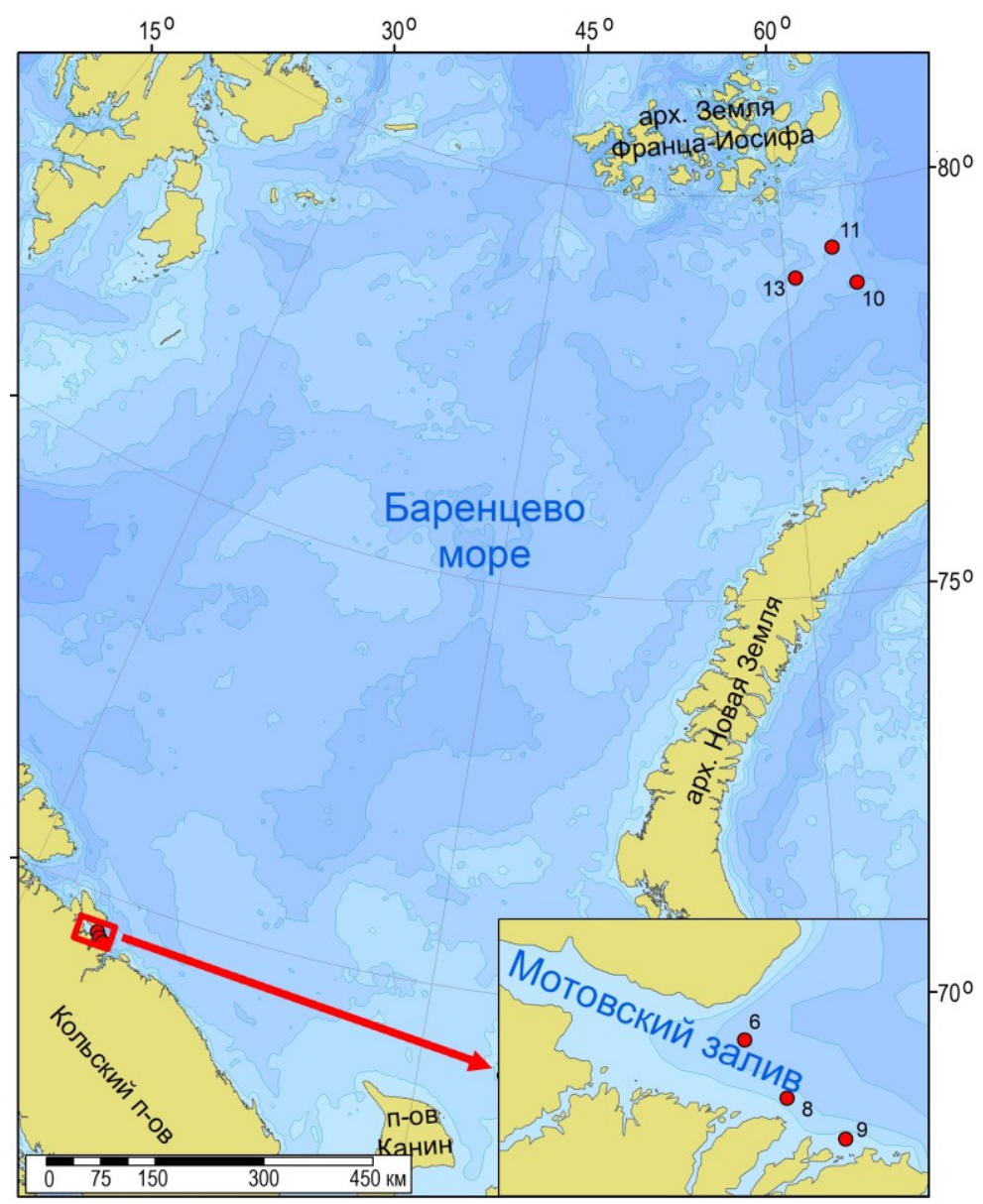

Рис. 1. Карта-схема расположения станций отбора проб воды в районах исследований в октябре 2017 и 2020 гг.

Fig. 1. Map of the water sampling stations location in the research areas in October 2017 and 2020

Для анализа были построены графики вертикального распределения. Интерполяция выполнена методом Кригинга с использованием программы Golden Software Surfer 13.

Результаты и обсуждение. По данным CTD-зондирования, температура вод в Мотовском заливе (станции $6,8,9$ ) изменялась от 3.9 до $7.1^{\circ} \mathrm{C}$, в северо-восточной части Баренцева моря (станции $10,11,13$ ) 
от -1.7 до $0.9^{\circ} \mathrm{C}$, диапазон солености составил, соответственно, $33.92-$ 34.45 и $33.49-34.84 \%$ (рис. 2).
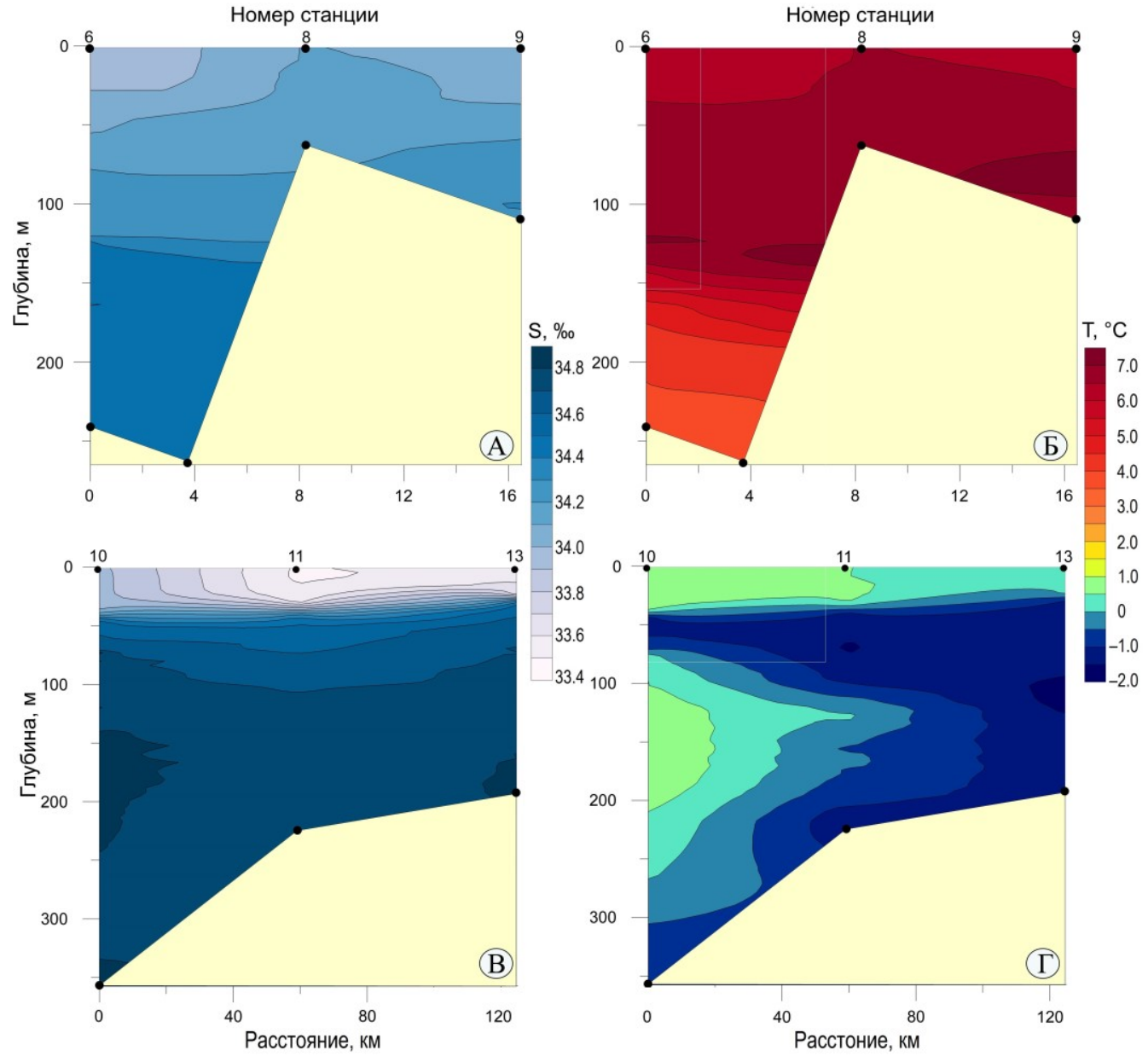

Рис. 2. Вертикальное распределение солености и температуры в Мотовском заливе в октябре 2017 г. (А, Б) и северо-восточной части Баренцева моря в октябре 2020 г. (В, Г)

Fig. 2. Vertical distribution of salinity and temperature in the Motovsky Bay in October 2017 (A, Б) and in the north-eastern part of the Barents Sea in October $2020(\mathrm{~B}, \Gamma)$

В октябре 2017 г. в Мотовском заливе пикноклин отсутствовал, в северо-восточной части Баренцева моря 2020 г. он отмечался на всех станциях, однако на ст. 10 он располагался на глубине 40-50 м, на ст. 11 30-45 м, а на ст. $13-25-40$ м.

Количественные характеристики бактериопланктона на исследуемых нами акваториях представлены в таблицах 1 и 2. 
Численность $(N)$, биомасса $(B)$ и средний объем клеток $(V)$ бактериопланктона в Мотовском заливе в октябре 2017 г.

$\mathrm{T}$ a b l e 1

The values of the abundance $(N)$, biomass $(B)$ and the average cell volume $(V)$ of bacterioplankton of the Motovsky Bay in October 2017

\begin{tabular}{c|c|c|c|c|c}
\hline Станция & Горизонт, & $N, \cdot 10^{3}$ кл/мл & $B, \mathrm{M \Gamma} / \mathrm{M}^{3}$ & $B, \mathrm{M \Gamma} \mathrm{C} / \mathrm{M}^{3}$ & $V, \mathrm{MKM}^{3}$ \\
\hline 6 & 0 & 399 & 12.38 & 3.93 & 0.031 \\
& 10 & 421 & 21.11 & 5.85 & 0.050 \\
& 25 & 538 & 24.55 & 6.99 & 0.046 \\
& 50 & 509 & 26.59 & 7.29 & 0.052 \\
& 100 & 324 & 19.72 & 5.18 & 0.061 \\
8 & 242 (дно) & 148 & 7.26 & 2.02 & 0.049 \\
& 0 & 413 & 10.05 & 3.40 & 0.024 \\
& 10 & 409 & 14.53 & 4.43 & 0.036 \\
& 25 & 715 & 27.34 & 8.17 & 0.038 \\
9 & 50 & 610 & 28.17 & 7.99 & 0.046 \\
& 66 (дно) & 684 & 28.92 & 8.41 & 0.042 \\
& 0 & 611 & 29.07 & 8.18 & 0.048 \\
& 10 & 382 & 14.28 & 4.30 & 0.037 \\
& 25 & 577 & 22.08 & 6.60 & 0.038 \\
& 50 & 717 & 27.68 & 8.26 & 0.039 \\
& 100 & 198 & 8.78 & 2.51 & 0.044 \\
& 129 (дно) & 218 & 8.47 & 2.50 & 0.039
\end{tabular}

Т а блиц а 2

Численность $(N)$, биомасса $(B)$ и средний объем клеток $(V)$ бактериопланктона в северо-восточной части Баренцева моря в октябре 2020 г.

Values of the abundance $(N)$, biomass $(B)$ and average cell volume $(V)$ of bacterioplankton in the north-eastern part of the Barents Sea in October 2020

\begin{tabular}{|c|c|c|c|c|c|}
\hline Станция & Горизонт, м & $N, \cdot 10^{3}$ кл/мл & $B, \mathrm{M} \Gamma / \mathrm{M}^{3}$ & $B, \mathrm{M \Gamma} \mathrm{C} / \mathrm{M}^{3}$ & $V$, мкм $^{3}$ \\
\hline \multirow[t]{6}{*}{10} & 0 & 333 & 11.72 & 3.57 & 0.035 \\
\hline & 10 & 601 & 18.33 & 5.83 & 0.030 \\
\hline & 25 & 493 & 17.69 & 5.38 & 0.036 \\
\hline & 50 & 957 & 41.72 & 12.02 & 0.044 \\
\hline & 100 & 346 & 20.18 & 5.36 & 0.058 \\
\hline & 366 (дно) & 367 & 11.41 & 3.62 & 0.031 \\
\hline \multirow[t]{6}{*}{11} & 0 & 692 & 51.39 & 12.48 & 0.074 \\
\hline & 10 & 925 & 24.80 & 8.14 & 0.027 \\
\hline & 25 & 406 & 10.12 & 3.41 & 0.025 \\
\hline & 50 & 748 & 24.77 & 7.71 & 0.033 \\
\hline & 100 & 379 & 16.32 & 4.68 & 0.043 \\
\hline & 225 (дно) & 233 & 12.82 & 3.41 & 0.055 \\
\hline \multirow[t]{5}{*}{13} & 0 & 505 & 16.32 & 5.11 & 0.032 \\
\hline & 20 & 692 & 24.14 & 7.39 & 0.035 \\
\hline & 50 & 435 & 36.90 & 8.46 & 0.085 \\
\hline & 100 & 218 & 13.88 & 3.59 & 0.064 \\
\hline & 203 (дно) & 170 & 9.71 & 2.59 & 0.057 \\
\hline
\end{tabular}


В водах Мотовского залива диапазон численности бактерий составил $(148-717) \cdot 10^{3}$ кл/мл, биомассы - 7.26-29.07 мг/м³. Максимальные показатели количественных характеристик выявлены в слое 0-50 м, минимальные - преимущественно в придонном. Исключением была ст. 8, где наблюдалось достаточно равномерное распределение бактериопланктона. Следует отметить, что данная станция является мелководной (66 м). Средний объем клеток варьировал от 0.024 до 0.061 мкм $^{3}$. Максимум его значений приходился на горизонты 0,50 и 100 м, минимум - на 0 и 10 м. В целом в водном столбе крупные клетки находились на бо́льших глубинах, чем мелкие. Объемы клеток бактериопланктона на всем участке исследований, вне зависимости от горизонта, различались не более чем в 2 раза.

В северо-восточной части Баренцева моря диапазон численности

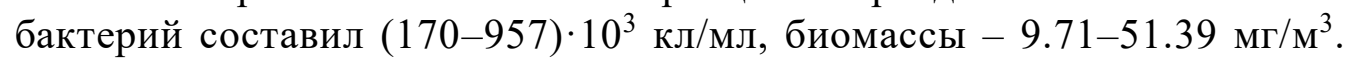
Максимум численности и биомассы наблюдался в слое 0-50 м. Минимальных значений показатели достигали преимущественно

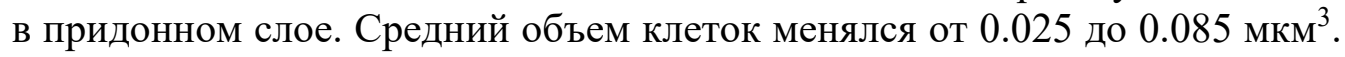
Закономерностей в его изменении с глубиной не отмечено, при этом клеточные объемы различались не более чем в 3 раза.

Соотношение размерно-морфологических групп представлено в табл. 3.

\section{Доля размерно-морфологических групп бактерий в общей численности бактериопланктона, \%}

Т а бли ц а 3

$\mathrm{Tab} l \mathrm{e} 3$

The proportion of size and morphological groups of bacteria in the total number of bacterioplankton, $\%$

\begin{tabular}{l|c|c|c}
\hline \multicolumn{1}{c|}{ Район } & $\begin{array}{c}\text { Мелкие клетки } \\
(<2 \text { мкм })\end{array}$ & $\begin{array}{c}\text { Крупные клетки } \\
(\geq 2 \text { мкм })\end{array}$ & $\begin{array}{c}\text { Агрегированные } \\
\text { формы }\end{array}$ \\
\hline Мотовский залив & 99.62 & 0.13 & 0.25 \\
Северо-восточная часть & 98.72 & 0.64 & 0.64 \\
Баренцева моря & & &
\end{tabular}

В состав бактериальных сообществ акваторий входили одиночные клетки (мелкие с размером меньше 2 мкм и крупные больше 2 мкм) и их агрегированные формы. При этом мелкие клетки составляли большинство в общей численности бактерий, процент крупных и агрегированных форм, как правило, не превышал 0.64. В Мотовском заливе численность агрегированных форм превышала количество крупных клеток, в северовосточной части Баренцева моря их соотношение было равным.

Основным источником органического вещества для бактериопланктона является фитопланктон, обилие которого можно косвенно оценить по концентрации хлорофилла $a$. 
В Мотовском заливе в октябре 2017 г. распределение хлорофилла было относительно равномерным, показатели находились в интервале

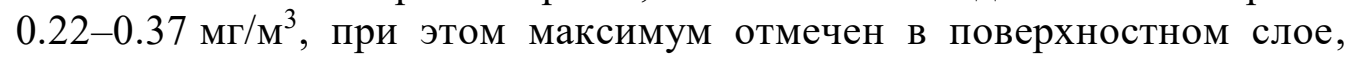
минимум - в придонном (Водопьянова, Духно, 2018).

Ранее установлено, что концентрация хлорофилла $a$ в осенний период на акватории от Земли Франца-Иосифа до Новой Земли составляет от 0.20 до 0.70 мг/м³ (Ведерников, Гагарин, 1998).

Таким образом, концентрация хлорофилла на обоих участках акватории Баренцева моря соответствует периоду, когда вегетация фитопланктона переходит в свою завершающую стадию.

В связи с отсутствием сведений по бактериопланктону Мотовского залива сравним полученные нами данные с таковыми других прибрежных районов (табл. 4).

Т а бли ц а 4

Численность $(N)$ и биомасса $(B)$ бактериопланктона
прибрежных и открытых вод Баренцева моря

Table 4

Values of the abundance $(N)$ and biomass $(B)$ of bacterioplankton for coastal and open waters of the Barents Sea

\begin{tabular}{|c|c|c|c|}
\hline Период & \begin{tabular}{|c|}
$N$, \\
$\cdot 10^{3}$ кл/мЛ \\
\end{tabular} & $\begin{array}{c}B, \\
\mathrm{M} \Gamma / \mathrm{M}^{3}\end{array}$ & $\begin{array}{c}\text { Литературный } \\
\text { источник }\end{array}$ \\
\hline \multicolumn{4}{|c|}{ Губа Зеленецкая (Дальнезеленецкая) } \\
\hline Октябрь-ноябрь 1983-1989 г & 558 & 179 & Байтаз, 1998 \\
\hline Октябрь-ноябрь 1984 г. & $325-668$ & $213-439$ & Теплинская, 1990 \\
\hline Сентябрь 1989 г. & $500-800$ & - & Комплексный ..., 1990 \\
\hline Октябрь-ноябрь 2017 г. & 700 & 36 & Венгер, 2019 \\
\hline \multicolumn{4}{|c|}{ Северо-восточная часть моря } \\
\hline Сентябрь-октябрь 1998 г & $10-240$ & $2-50$ & огические \\
\hline
\end{tabular}

Полученные нами результаты для бактериопланктона прибрежных вод сопоставимы с ранее опубликованными по численности, но имеют весьма существенные расхождения по биомассе. Это, в первую очередь, может быть связано с особенностью методики окрашивания бактерий. При этом данные, полученные для Мотовского залива и губы Зеленецкая осенью 2017 г., демонстрируют максимальное сходство, что свидетельствует о единообразии условий, наблюдавшихся в осенний период на рассматриваемых акваториях.

В северо-восточной части Баренцева моря в октябре 2020 г. численность была в несколько раз выше, чем отмечено в более ранних исследованиях, а биомасса - сопоставима. В то же время зарегистрированные нами показатели численности бактерий близки к таковым летнего периода 2009 и 2010 гг. в открытой части моря (архипелаг Земля Франца-Иосифа; Венгер, 2011). 
Для изучения закономерностей пространственного распределения бактериопланктона в толще воды была выполнена интерполяция. Ее результаты представлены на рис. 3 .

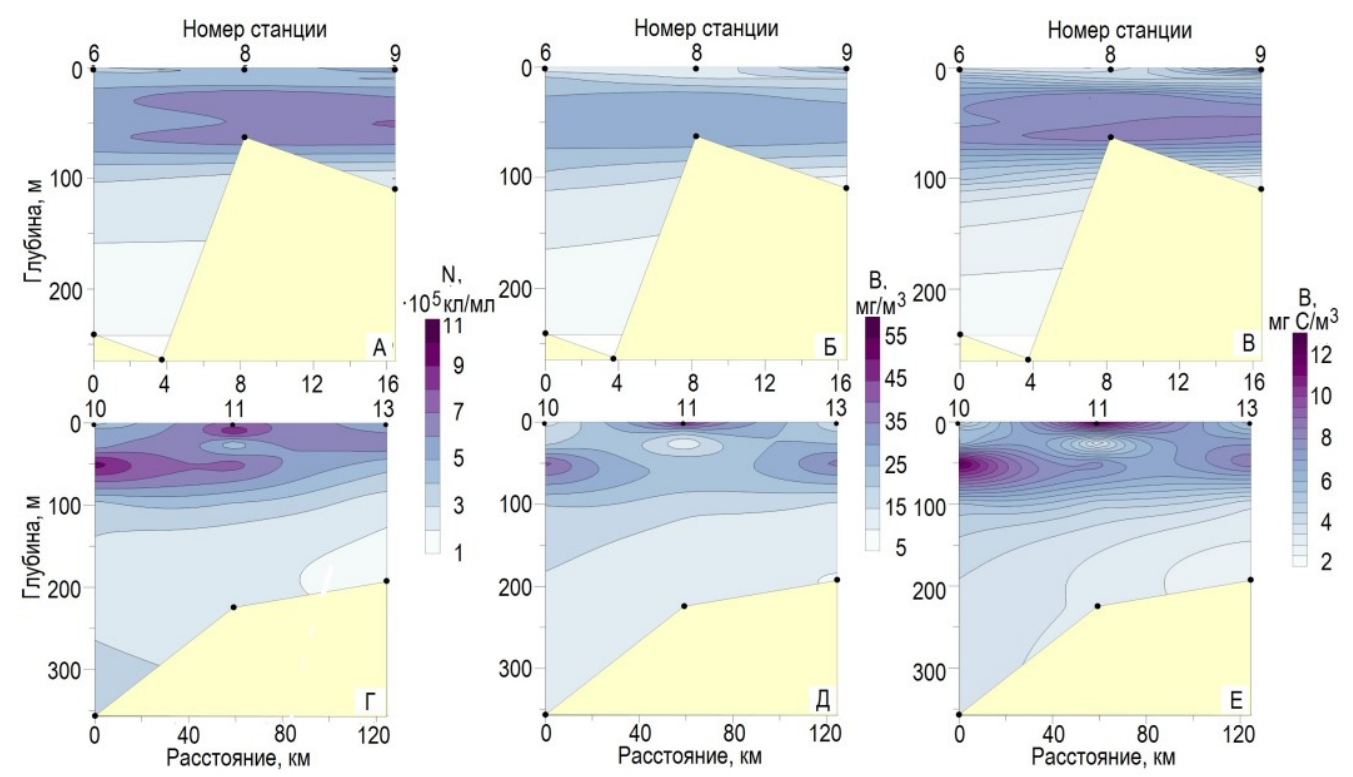

Рис. 3. Распределение численности и биомассы бактериопланктона в Мотовском заливе в октябре 2017 г. (А, Б, В) и северо-восточной части Баренцева моря в октябре 2020 г. (Г, Д, Е)

Fig. 3. Distribution of quantity and biomass bacterioplancton in the Motovsky Bay in October 2017 (A, Б, B) and in the north-eastern part of the Barents Sea in October $2020(\Gamma$, Д, E)

В Мотовском заливе высокие концентрации бактерий отмечались в верхнем 100-метровом слое, снижение значений - от 100 м и глубже. В северо-восточной части моря распределение бактериопланктона было мозаичным, высокие значения численности и биомассы отмечены на различных глубинах.

Корреляционный анализ показал отсутствие связи между бактериями и факторами среды.

Согласно анализу численности и биомассы бактерий в прибрежной и открытой частях моря по $U$-критерию Манна-Уитни они принадлежат одной и той же генеральной совокупности.

Заключение. Количественные показатели бактериопланктона Мотовского залива и северо-восточной части моря соответствовали значениям, установленным ранее для осеннего периода. При этом значения численности бактерий как открытых, так и прибрежных вод были сопоставимы, биомассы незначительно отличались, имея бо́льшие значения в открытых водах. Основная часть бактериопланктона сконцентрирована в верхних слоях водной толщи. 
В бактериоценозах преобладали мелкие одиночные клетки размером $<2$ мкм, их доля составила свыше $98 \%$ в общей численности.

Работа выполнена по теме 9-17-01 (133) “Особенности организации арктических планктонных сообществ в условиях современных климатических изменений (Баренцево, Карское моря и море Лаптевых)" (№ 0228-2019-0003) в рамках государственного задания.

\section{Литература}

Байтаз В.А., Байтаз О.Н. Количественные и продукционные характеристики бактериального населения прибрежной зоны Баренцева моря // Продукционнодеструкционные процессы пелагиали прибрежья Баренцева моря. Апатиты: Изд-во КНЦ АН СССР, 1991. С. 20-33.

Байтаз О.Н. Сравнительная характеристика количественных и продукционных показателей губы Дальнезеленецкая и юго-восточной части Баренцева моря // Экология и биологическая продуктивность Баренцева моря. М.: Наука, 1990. C. $78-87$.

Байтаз О.Н. Пространственно-временная изменчивость бактериопланктона Баренцева моря: Автореф. дис. ... канд. биол. наук (03.00.18 - гидробиология). M., 1998.25 c.

Бактериопланктон и факторы среды высокоширотных районов Баренцева моря в апреле 2016 г. / Т.И. Широколобова, М.П. Венгер, А.П. Жичкин, И.А. Пастухов // Материалы научных мероприятий, приуроченных к 15-летию Южного научного центра Российской академии наук (г. Ростов-на-Дону, 1316 декабря 2017 г.). Ростов н/Д.: Изд-во ЮНЦ РАН, 2017. С. 293-296.

Ведерников В.И., Гагарин В.И. Первичная продукция и хлорофилл в Баренцевом море в сентябре-октябре 1997 г. // Океанология. 1998. Т. 38, № 5. C. 710-717.

Венгер М.П. Бактериопланктон северо-восточной части Баренцева моря // Вестн. Южного науч. центра РАН. 2011. Т. 7, № 4. С. 55-60.

Венгер М.П. Результаты исследования микропланктонных сообществ в губе Дальнезеленецкой летом 2012 г. // Материалы XXXI конференции молодых ученых ММБИ. Мурманск: Изд. ММБИ КНЦ РАН, 2013. С. 38-45.

Венгер М.П. Сезонные изменения количественных характеристик бактериопланктона губы Зеленецкая Баренцева моря // Исследования арктических экосистем: Матер. XXXVII конф. молодых ученых ММБИ КНЦ РАН. Апатиты: Изд-во КНЦ РАН, 2019. С. 27-34.

Водопьянова В.В., Духно Г.Н. Содержание хлорофилла $а$ в водах Кольского и Мотовского заливов Баренцева моря в осенний период // Сборник статей по материалам международной научно-практической конференции “Экологическая, промышленная и энергетическая безопасность - 2018”. Севастополь: СевГУ, 2018. С. 241-245.

Boдbl Баренцева моря: структура, циркуляция, изменчивость / В.К. Ожигин, В.А. Ившин, А.Г. Трофимов, А.Л. Карсаков, М.Ю. Анциферов. Мурманск: Изд-во ПИНРО, 2016. 260 с.

Добровольский А.Д., Залогин Б.С. Моря СССР. М.: Изд-во Моск. гос. ун-та, 1982, $192 \mathrm{c}$.

Исаченко Б.Л. Исследования над бактериями Северного Ледовитого океана // Тр. Мурм. науч.-пром. экспед. 1906-1914 гг. Петроград, 1914. 297 с. 
Комплексный экологический мониторинг в губе Дальнезеленецкая (Баренцево море): летне-осенний период 1989 г. Структурные характеристики / С.И. Бардан, Н.В. Дружков, В.А. Байтаз и др.: Препр. Апатиты: Изд-во КНЦ АН СССР, $1990.38 \mathrm{c}$.

Микробиологические исследования северной части Баренцева моря в начале зимнего сезона / А.С. Саввичев, И.И. Русанов, Н.В. Пименов и др. // Микробиология. 2000. Т. 69, № 6. С. 819-830.

Панченко А.А. Баренцево море (история, экономика, экология). Учеб. пособие. Мурманск: Изд. Мурм. высш. инж.-мор. уч-ща им. Ленинского Комсомола, $1991.115 \mathrm{c}$.

Периева T.A. Нерест, икринки и мальки рыб в Мотовском заливе // Тр. ВНИРО. 1939. Т. 4. С. 36-48.

Планктон морей Западной Арктики / Отв. ред. Г.Г. Матишов. Апатиты: Изд-во КНЦ РАН, 1997. 352 с.

Теплинская Н.Г. Процессы бактериальной продукции и деструкции органического вещества в северных морях. Апатиты: Изд-во КФ АН СССР, 1990. $106 \mathrm{c}$.

Экология и биологическая продуктивность Баренцева моря / Под ред. Г.Г. Матишова. М.: Наука, 1990. 119 с.

Microbial ecology of the oceans. New Jersey: Wiley-Blackwell, 2008. 620 p.

Porter K.G., Feig Y.S. The use DAPI for identifying and counting of aquatic microflora // Limnol. Oceanogr. 1980. Vol. 25, № 5. P. 943-948.

Vargas C.A., González H.E. Plankton community structure and carbon cycling in a coastal upwelling system. I. Bacteria, microprotozoans and phytoplankton in the diet of copepods and appendicularians // Aquat. Microb. Ecol. 2004. Vol. 34. P. 151-164.

DOI: 10.37614/2307-5252.2021.3.9.006

УДК $579.68(268.45)$

\section{М.П. Венгер}

Мурманский морской биологический институт РАН, г. Мурманск, Россия

\section{ВИРИО- И БАКТЕРИОПЛАНКТОН БАРЕНЦЕВА МОРЯ В ОСЕННИЙ ПЕРИОД}

\section{Аннотация}

В осенний период 2011, 2015 гг. в водах Баренцева моря исследованы сообщества вирусов и бактерий, определен их количественный состав и изучен характер распределения. Показано, что распределение вирио- и бактериопланктона имело выраженную зональность, обусловленную, предположительно, повышенными концентрациями органического вещества в более продуктивных прибрежных и атлантических водах, чем в арктических. В сентябре 2011 г. количество вирусов колебалось от 0.6 до 46.7 млн частиц/мл, превышая таковое бактерий в среднем в 5 раз. Численность бактериопланктона изменялась в пределах 0.3-2.9 млн кл/мл, биомасса - 4.1-35.1 мг С/m³ , средний объем клеток - 0.030-0.115 мкм³. В ноябредекабре 2015 г. обилие вирусов составляло 0.3-6.4 млн частиц/мл и количественно превосходило своих хозяев бактерий в среднем в 18 раз. Численность и биомасса 
бактерий соответствовала 0.02-0.3 млн кл/мл и 0.3-2.7 мг C/M ${ }^{3}$ при среднем объеме клеток 0.013-0.068 мкм³. Установлено, что уровень развития вирио- и бактериопланктона существенно снижается к позднеосеннему периоду.

Ключевые слова: вириопланктон, бактериопланктон, Баренцево море.

\section{M.P. Venger}

Murmansk Marine Biological Institute RAS, Murmansk, Russia

\section{VIRIO- AND BACTERIOPLANKTON OF THE BARENTS SEA IN THE AUTUMN}

\section{Abstract}

In the autumn period 2011, 2015 in the waters of the Barents Sea, the communities of viruses and bacteria were studied, their quantitative composition was determined, and the nature of their distribution was studied. It was shown that the distribution of both virio- and bacterioplankton had pronounced zoning presumably due to increased concentrations of organic matter in more productive coastal and Atlantic waters compared to the Arctic. In September 2011, the number of viruses varied from 0.6 to 46.7 million particles/ml, exceeding the abundance of bacteria by 5 times an average. The quantity of bacterioplankton varied within $0.3-2.9$ million cells $/ \mathrm{ml}$, biomass 4.1-35.1 $\mathrm{mg} \mathrm{C} / \mathrm{m}^{3}$, with a range of mean cell volumes of $0.030-0.115 \mu \mathrm{m}^{3}$. In November-December 2015, the abundance of viruses was 0.3-6.4 million particles $/ \mathrm{ml}$ and quantitatively exceeded their bacterial hosts by 18 times an average. The quantity and biomass of bacteria varied within $0.02-0.3$ million cells $/ \mathrm{ml}$ and $0.3-2.7 \mathrm{mg} \mathrm{C} / \mathrm{m}^{3}$, with a range of mean cell volumes of $0.013-0.068 \mu \mathrm{m}^{3}$. It was found that the level of development of virio- and bacterioplankton significantly decreased by the late autumn period.

Keywords: virioplankton, bacterioplankton, Barents Sea.

С наступлением осени в арктических морях снижается уровень инсоляции, что приводит к замедлению автотрофного синтеза органического вещества, поэтому в экосистемах пелагиали начинают доминировать деструкционные процессы. Основная часть этих процессов протекает при участии представителей микробной пищевой сети. Сравнительно недостаточная изученность ее наиболее массовых компонентов - вирусов и бактерий - в северных морях России обусловила актуальность наших исследований.

Цель работы - анализ количественных характеристик вириои бактериопланктона и особенностей их распределения в водах Баренцева моря в осенний период.

Материал был собран в комплексных экспедициях Мурманского морского биологического института на разрезе "Кольский меридиан" в сентябре 2011 г. и ноябре-декабре 2015 г. (рисунок). Пробы воды отбирали по стандартным горизонтам пластиковыми батометрами Нискина, установленными на системе Rozett. Для измерения глубин и термохалинных характеристик использовали СТД-зонд SBE 19plus V2 SeaCAT. 


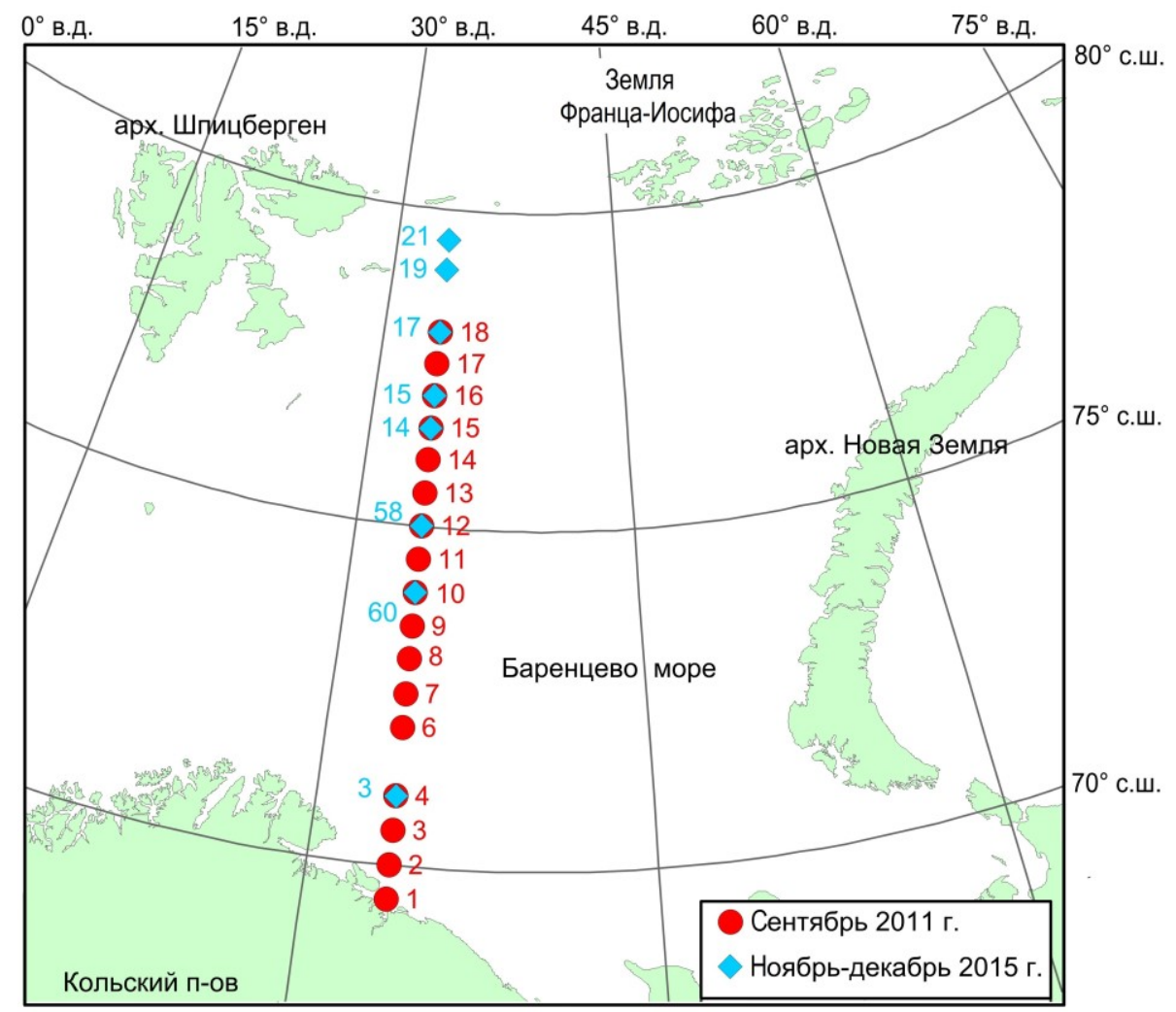

Карта-схема станций отбора проб воды

Map of water sampling stations

Подсчет вирусных частиц и бактериальных клеток осуществляли стандартным методом эпифлуоресцентной микроскопии. Численность $(N)$ и размеры клеток $(V)$ бактериопланктона определяли с помощью флуорохрома DAPI (Porter, Feig, 1980) и фильтров ОИЯИ (г. Дубна) с диаметром пор 0.2 мкм, количество вирусов - с помощью флуорохрома SYBR Green I и фильтров Anodisc (“Wathman”) с диаметром пор 0.02 мкм (Noble, Fuhrman, 1998). Бактериальную биомассу (B) рассчитывали в углеродных единицах (Norland, 1993).

Количество контактов между вирусами и бактериями рассчитывали по формуле (Marray, Jackson, 1992)

$$
R=S h 2 \pi w D_{\mathrm{v}} V P
$$

где $S h$ - число Шервуда (использовали величину 1.01, принимаемую для неподвижных бактерий); $w$ - диаметр бактериальной клетки; $V$ и $P$ численность вирусов и бактерий соответственно; $D_{\mathrm{v}}-$ диффузия (распространение вирусов). Диффузию определяли по уравнению 


$$
D_{\mathrm{v}}=\frac{k T}{3 \pi \mu d_{\mathrm{v}}}
$$

где $k$ - константа Больцмана $\left(1.38 \cdot 10^{-23}\right.$ Дж/К), $T$ - температура in situ в градусах Кельвина, $\mu$ - вязкость воды, $d_{\mathrm{v}}-$ диаметр вирусного капсида.

При статистической обработке материала использовали метод ранговой корреляции Спирмена для расчета $r_{\mathrm{s}}$ и $U$-критерий Манна-Уитни. Достоверными считали различия при $p \leq 0.05$.

В соответствии с диапазонами внутригодовых изменений температуры и солености различных типов вод Баренцева моря (Воды ..., 2016) на изученной акватории было выделено три участка: южный, занятый водами прибрежья (34.24-34.78 \%о), центральный - водами Атлантики (34.72-35.08 \%), северный - полярными водами смешанного генезиса (33.60-35.01 \%), которые далее в тексте называем арктическими (табл. 1). Необходимо отметить, что оба года исследований относились к аномально теплым и характеризовались повышенными температурами воды и воздуха, а также малой ледовитостью (Трофимов и др., 2018).

Т а б ли ц а 1

Термохалинная характеристика водных масс Баренцева моря

Thermohaline characteristics of the water masses in the Barents Sea

T a b l e 1

\begin{tabular}{|c|c|c|c|c|}
\hline Водная масса & $\begin{array}{l}\text { Номера } \\
\text { станций }\end{array}$ & $\begin{array}{c}\text { Глубина, } \\
\text { м }\end{array}$ & $\begin{array}{c}\text { Tемпература, } \\
{ }^{\circ} \mathrm{C}\end{array}$ & $\begin{array}{c}\text { Соленость, } \\
\% о\end{array}$ \\
\hline & Сент & 5 брь 2011 г. & & \\
\hline \multirow[t]{3}{*}{ Прибрежная мурманская } & $1-4$ & $0-25$ & $8.9-9.0$ & $34.24-34.43$ \\
\hline & & 50 & $6.2-7.5$ & $34.50-34.67$ \\
\hline & & $100-261^{*}$ & $2.5-5.3$ & $34.65-34.78$ \\
\hline \multirow[t]{3}{*}{ Атлантическая } & $6-14$ & $0-25$ & $6.3-8.6$ & $34.72-34.99$ \\
\hline & & 50 & $4.4-6.9$ & $34.98-35.08$ \\
\hline & & $100-297^{*}$ & $-0.6 \ldots 5.0$ & $34.91-35.08$ \\
\hline \multirow[t]{5}{*}{ Арктическая } & $15-18$ & $0-25$ & $0.7-4.3$ & $33.60-34.02$ \\
\hline & & 50 & $-1.6 \ldots-1.1$ & $34.33-34.46$ \\
\hline & & 100 & $-0.9 \ldots-0.6$ & $34.49-34.64$ \\
\hline & & $156^{*}-190^{*}$ & $0.8-1.4$ & $34.90-34.95$ \\
\hline & Ноябрь- & екабрь 2015 г. & & \\
\hline \multirow{3}{*}{ Прибрежная мурманская } & 3 & $0-25$ & 6.8 & 34.43 \\
\hline & & 50 & 6.8 & 34.43 \\
\hline & & $100-200^{*}$ & $3.3-6.5$ & $34.62-34.65$ \\
\hline \multirow[t]{3}{*}{ Атлантическая } & 58,60 & $0-25$ & $3.2-6.5$ & $35.02-35.05$ \\
\hline & & 50 & $3.1-5.2$ & $35.01-35.04$ \\
\hline & & $100-299^{*}$ & $1.0-5.2$ & $35.01-35.04$ \\
\hline \multirow{4}{*}{ Арктическая } & $14,15,17$ & $0-25$ & $-1.2 \ldots 2.2$ & $34.08-34.75$ \\
\hline & 19,21 & $50-70$ & $-0.9 \ldots 2.2$ & $34.11-34.75$ \\
\hline & & 100 & $-0.1 \ldots 2.1$ & $34.61-34.76$ \\
\hline & & $150^{*}-212^{*}$ & $0.8-1.9$ & $34.80-35.01$ \\
\hline
\end{tabular}

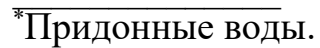

48 
Годовой цикл гидрологического режима Баренцева моря подразделяется на четыре сезона, в границах которых сентябрь относится к началу осеннего сезона, ноябрь-декабрь - к его окончанию и началу зимы (Шавыкин, Ильин, 2010). Продолжительность светового дня в границах разреза "Кольский меридиан” в сентябре 2011 г. составляла около 12 ч, в ноябре-декабре 2015 г. - снижалась до 3 ч на самой южной станции, а севернее нее исследования выполнялись в условиях наступившей полярной ночи.

В сентябре 2011 г. численность вирусов изменялась от 0.6 до 46.7 млн частиц/мл, превышая таковое бактерий в среднем в 5 раз. Рассчитанное количество контактов между ними составляло 0.4-143.3 (в среднем 12.7) в сутки. Минимальное количество вирусных частиц отмечено в арктических водах, где средние значения в слое 0-50 м и в придонных водах были сопоставимы (табл. 2). В прибрежных и атлантических водах в слое 0-25 м концентрация вирусов была максимальной, снижаясь с глубиной в среднем в 3.3 раза.

Численность бактериопланктона изменялась в пределах $0.3-$ 2.9 млн кл/мл, биомасса - 4.1-35.1 мг $\mathrm{C} / \mathrm{M}^{3}$, средний объем клеток 0.030-0.115 мкм ${ }^{3}$. Повышенные величины количественных показателей выявлены в слое 0-25 м, с глубиной они снижались и в придонных слоях вод на исследованной акватории достоверно не различались между собой.

В ноябре-декабре 2015 г. обилие вирусов составляло 0.36.4 млн частиц/мл и превосходило таковое бактерий в среднем в 18 раз. Количество контактов изменялось от 0.01 до 1.4 (в среднем 0.3) в течение суток. Максимальная концентрация вирусных частиц наблюдалась в атлантических водах по всей водной толще. Минимальными значениями характеризовались арктические воды, где количество вирусов с глубиной достоверно снижалось в 1.3 раза. Прибрежные воды занимали промежуточное положение - обилие вирусов достоверно снижалось к придонным слоям в среднем в 2 раза.

Численность бактерий составляла 0.02-0.3 млн кл/мл, биомасса 0.3-2.7 мг $\mathrm{C} / \mathrm{M}^{3}$ при среднем объеме клеток 0.013-0.068 мкм ${ }^{3}$. В прибрежных и атлантических водах количественные показатели по всей водной толще были однородными. Плотность скопления бактериопланктона уменьшалась к арктическим водам, где численность и биомасса клеток была на порядок ниже средних значений, наблюдаемых на разрезе. В арктических водах численность и биомасса бактерий снижалась с глубиной и достоверно отличалась в слоях 0-50 м и придонном.

При сравнении полученных данных с литературными сведениями было выявлено, что в сентябре 2011 г. вирусы и бактерии имели показатели, сопоставимые с летними. В центральной части Баренцева моря (июньиюль 1999 г., август 2010 г.) количество бактериальных клеток изменялось от 0.4 до 4.1 млн кл/мл, биомасса варьировала от 8.0 до $26.1 \mathrm{мг} \mathrm{C} / \mathrm{M}^{3}$, численность вириопланктона составляла 1.7-35.8 млн частиц/мл 
(Distribution ..., 2002; Влияние ..., 2016). Данные в ноябре-декабре 2015 г. сопоставимы с результатами, полученными зимой в зоне влияния Мурманского прибрежного течения - 0.2-0.7 млн кл/мл (Планктон ..., 1997) и в водах западного участка Баренцева моря, где численность, биомасса и средние объемы бактериальных клеток находились в пределах 0.3-0.6 млн кл/мЛ, 2.2-8.3 мг С/ $\mathrm{M}^{3}$ и 0.021-0.058 мкм ${ }^{3}$ соответственно (Венгер, 2020). Обилие вирусных частиц в наших исследованиях имело более широкий диапазон и низкие минимальные значения, чем в феврале в заливе Франклина (1.4-4.5 млн частиц/мл) (Wells, Deming, 2006) и в северном районе Баренцева моря в период окончания зимы (0.94.0 млн частиц/мл (Широколобова и др., 2017).

По уровню бактериального развития трофический статус (Сорокин и др., 1996) баренцевоморских вод снижался от мезотрофного в сентябре до олиготрофного в ноябре-декабре, что, вероятно, обусловлено состоянием фитопланктона - основного поставщика лабильного субстрата для бактерий. В сентябре это состояние оценивается как предосеннее с серией факультативных второстепенных пиков развития (Планктон ..., 1997). В южных и центральных районах Баренцева моря биомасса фитоцена в сентябре может достигать 400-500 мкг/л (Бардан и др., 1990; Кузнецов и др., 1996). С ноября по февраль пелагические альгоценозы пребывают в стадии покоя и характеризуются низкими показателями количественного развития. Так в ноябре-декабре 2012, 2013 и 2015 гг. на разрезе "Кольский меридиан” от 70 до $78^{\circ}$ с. ш. максимальная биомасса фитопланктона не превышала 1.14 мкг/л (Макаревич, Олейник, 2017).

Анализ материала, полученного в ходе двух экспедиций, позволил проследить изменения в структуре вирио- и бактериопланктона Баренцева моря. В сентябре 2011 г. повышенное содержание бактерий было характерно для верхнего 25-метрового слоя по всему водному профилю разреза, численность и биомасса бактерий снижалась ко дну в среднем в 3 раза и превышала аналогичные величины, полученные в ноябре-декабре 2015 г., когда бактериопланктон распределялся относительно равномерно в прибрежных и атлантических водах, в арктических - показатели снижались на порядок величин и достоверно уменьшались от 0-50 м к придонному слою в среднем в 2 раза. В конце осеннего периода, в ноябре-декабре 2015 г., бактериопланктон не достигал минимальных значений, зарегистрированных в придонных водах в начале сезона 2011 г.

Нами проведено сравнение средних объемов бактериальных клеток. В сентябре 2011 г. клетки бактерий были крупнее в 1.5-3.5 раза, чем в ноябре-декабре 2015 г. Полученные результаты подтверждают, что в низкопродуктивных водах преобладают бактерии относительно малых размеров, так как с уменьшением объемов клеток увеличивается их удельная поверхность и, как следствие, активнее протекают метаболические процессы (Байтаз, 1990). 
Количественная характеристика вирио- и бактериопланктона в Баренцевом море

$\mathrm{Tab} l \mathrm{e} 2$

Quantitative characteristics of virio- and bacterioplankton in the Barents Sea

\begin{tabular}{|c|c|c|c|c|c|}
\hline \multirow[b]{2}{*}{ Параметр } & \multirow[b]{2}{*}{$\begin{array}{l}\text { Водная } \\
\text { масса }\end{array}$} & \multicolumn{4}{|c|}{ Глубина } \\
\hline & & $0-25 \mathrm{M}$ & $50 \mathrm{M}$ & $100 \mathrm{M}$ & $\begin{array}{c}200 \text { м- } \\
\text { придонные } \\
\text { воды }\end{array}$ \\
\hline \multicolumn{6}{|c|}{ Вириопланктон } \\
\hline \multicolumn{6}{|c|}{ Сентябрь 2011 г. } \\
\hline$N$, & Прибрежная & $8.3 \pm 1.2$ & $4.8 \pm 2.9$ & - & $3.5 \pm 0.7$ \\
\hline \multirow[t]{3}{*}{ млн частиц/мл } & Атлантическая & $12.3 \pm 2.2$ & $2.5 \pm 1.1$ & $2.9 \pm 1.1$ & $3.3 \pm 0.7$ \\
\hline & Арктическая & $1.7 \pm 0.3$ & $1.4 \pm 0.5$ & $1.0 \pm 0.3$ & $1.5 \pm 0.1$ \\
\hline & \multicolumn{5}{|c|}{ Ноябрь-декабрь 2015 г. } \\
\hline$N$ & Прибрежная & $1.7 \pm 0.2$ & 1.9 & 1.1 & 1.2 \\
\hline \multirow[t]{2}{*}{ млн частиц/мл } & Атлантическая & $4.4 \pm 0.8$ & $4.3 \pm 1.3$ & - & $4.8 \pm 0.4$ \\
\hline & Арктическая & $1.1 \pm 0.3$ & $1.2 \pm 0.3$ & $0.9 \pm 0.1$ & $0.9 \pm 0.2$ \\
\hline \multicolumn{6}{|c|}{ Бактериопланктон } \\
\hline & & Сентябрь 20 & & & \\
\hline \multirow[t]{3}{*}{$N$, млн кл/мл } & Прибрежная & $2.0 \pm 0.1$ & $1.2 \pm 0.3$ & $0.6 \pm 0.04$ & $0.5 \pm 0.02$ \\
\hline & Атлантическая & $1.6 \pm 0.1$ & $0.6 \pm 0.1$ & $0.4 \pm 0.04$ & $0.5 \pm 0.05$ \\
\hline & Арктическая & $1.2 \pm 0.2$ & $1.1 \pm 0.5$ & $0.4 \pm 0.002$ & 0.5 \\
\hline \multirow{3}{*}{$B, \mathrm{мг} \mathrm{C} / \mathrm{M}^{3}$} & Прибрежная & $25.0 \pm 2.2$ & $14.4 \pm 0.04$ & $7.9 \pm 0.8$ & $5.9 \pm 0.5$ \\
\hline & Атлантическая & $22.1 \pm 1.1$ & $9.8 \pm 1.6$ & $5.2 \pm 0.5$ & $8.5 \pm 0.8$ \\
\hline & Арктическая & $18.0 \pm 2.1$ & $15.9 \pm 8.3$ & $6.4 \pm 1.1$ & 9.0 \\
\hline \multirow{4}{*}{$V$, мкм $^{3}$} & Прибрежная & \multicolumn{4}{|c|}{$0.043 \pm 0.002 \quad 0.046 \pm 0.016 \quad 0.053 \pm 0.0140 .048 \pm 0.006$} \\
\hline & Атлантическая & $0.056 \pm 0.002$ & $.067 \pm 0.017$ & $0.056 \pm 0.003$ & $0.071 \pm 0.008$ \\
\hline & Арктическая & & $.056 \pm 0.002$ & $0.062 \pm 0.018$ & 0.070 \\
\hline & \multicolumn{5}{|c|}{ Ноябрь-декабрь 2015 г. } \\
\hline \multirow[t]{3}{*}{$N$, млн кл/мл } & Прибрежная & $0.2 \pm 0.04$ & 0.1 & 0.3 & 0.1 \\
\hline & Атлантическая & $0.2 \pm 0.03$ & $0.2 \pm 0.01$ & 0.2 & $0.2 \pm 0.1$ \\
\hline & Арктическая & $0.07 \pm 0.01$ & $0.1 \pm 0.04$ & $0.05 \pm 0.01$ & $0.04 \pm 0.01$ \\
\hline \multirow[t]{3}{*}{$B, \mathrm{мг} \mathrm{C} / \mathrm{M}^{3}$} & Прибрежная & $1.6 \pm 0.2$ & - & 2.7 & 1.0 \\
\hline & Атлантическая & $1.7 \pm 0.2$ & $2.0 \pm 0.02$ & 1.8 & $2.2 \pm 0.04$ \\
\hline & Арктическая & $0.9 \pm 0.1$ & $1.1 \pm 0.4$ & $0.5 \pm 0.1$ & $0.4 \pm 0.1$ \\
\hline \multirow[t]{3}{*}{$V$, мкм $^{3}$} & Прибрежная & $0.026 \pm 0.004$ & 0.013 & 0.032 & 0.029 \\
\hline & Атлантическая & $0.028 \pm 0.003$ & $.034 \pm 0.006$ & 0.025 & $0.039 \pm 0.002$ \\
\hline & Арктическая & $0.040 \pm 0.003$ & $.036 \pm 0.004$ & $.039 \pm 0.00$ & $0.049 \pm 0.006$ \\
\hline
\end{tabular}

В исследуемый период на разрезе “Кольский меридиан" вириопланктон имел повышенные концентрации в прибрежных и атлантических водах, пониженные - в арктических. В сентябре 2011 г. вирусов было в 3.3 раза больше, чем в ноябре-декабре 2015 г. В конце осеннего периода в 2015 г. количество вирусных частиц положительно коррелировало с численностью и биомассой бактерий. Связь этих показателей достигала величин $r_{\mathrm{s}}=0.60$ и $r_{\mathrm{s}}=0.58$ при $\mathrm{n}=22$ соответственно, что свидетельствует о преобладании бактериофагов 
в вирусном сообществе, поскольку вирусы тесно связаны с численностью своих хозяев и любые изменения в численности или метаболизме последних влияют на количество вириопланктона (Spatial .., 1993; Wommack, Colwell, 2000). Отсутствие значимой корреляции между бактериями и вирусами в начале осеннего периода в 2011 г. указывает на то, что с большой долей вероятности в вирусном сообществе наряду с бактериофагами преобладают альгофаги.

В сентябре 2011 г. между вирусами и бактериями было обнаружено повышенное количество контактов в прибрежных и атлантических водах, скорость контактов между ними составляла в среднем 17.2 в сутки, снижаясь в арктических водах в 8 раз. В ноябре-декабре 2015 г. количество контактов повсеместно было незначительное (не более 1.4 в сутки) и в 17 раз ниже, чем в начале осеннего периода 2011 г. Ранее было установлено, что вероятной причиной этого может быть повышенная вязкость воды на фоне ее пониженных температур и низкая численность основного хозяина - бактерий (Cottrell, Kirchman, 2012).

Таким образом, впервые за последние 20 лет на разрезе "Кольский меридиан" (с 69 по 80 с. ш.) выполнен анализ микробиологических сообществ в осенний период. Установлено, что в начале этого периода (2011 г.) показатели вирио- и бактериопланктона соответствуют летним значениям и основная часть сообщества концентрируется в верхнем слое водной толщи. Это определяется доступностью для микробных сообществ органического вещества, образованного фитопланктоном в процессе вегетации. Доминируют альгофаги, высокая численность которых в верхнем фотическом слое может быть следствием лизиса фитопланктонных клеток и высвобождения нового вирусного потомства. Завершение осеннего периода (2015 г.) сопровождается уменьшением фотосинтетической активности фитоценов и вследствие этого повсеместным снижением количественных характеристик вирусов и бактерий до значений, характерных для зимнего периода, лидирующая роль принадлежит бактериофагам.

Работа выполнена в рамках государственного задания.

\section{Литература}

Байтаз B.A. Взаимосвязи с величиной удельной поверхности их клеток // Структурно-функциональная организация экосистем Баренцева моря. Апатиты: Изд-во КНЦ АН СССР, 1990. С. 224-232. Деп. в ВИНИТИ 05.10.90. № 5272-В90.

Бардан С.И., Бобров Ю.А., Дружков Н.В. Комплексный экологический мониторинг в губе Дальнезеленецкая (Баренцево море): летне-осенний период 1989 г. Функциональные характеристики: Препр. Апатиты: Изд-во КНЦ АН CCCP, $1990.44 \mathrm{c}$.

Венгер М.П. Распределение и сезонная динамика бактериопланктона вдоль западной границы Баренцева моря // Тр. Кольского науч. центра РАН. 2020. T. 5(11). Сер. Океанология. Вып. 8. С. 37-50. 
Влияние вирусов на бактериопланктон открытой и прибрежной части Баренцева моря / М.П. Венгер, А.И. Копылов, Е.А. Заботкина, П.Р. Макаревич // Биология моря. 2016. Т. 42, № 1. С. 19-26.

Bоды Баренцева моря: структура, циркуляция, изменчивость / В.К. Ожигин, В.А. Ившин, А.Г. Трофимов и др. Мурманск: Изд-во ПИНРО, 2016. 259 с.

Күзнеиов Л.Л., Дружков Н.В., Байтаз О.Н. Прибрежные экосистемы пелагиали Баренцева моря // Экосистемы пелагиали морей Западной Арктики. Апатиты: Изд-во КНЦ РАН, 1996. С. 73-84.

Макаревич П.Р., Олейник А.А. Микропланктон Баренцева моря: современный состав и структура в предзимний период // Вестн. Мурм. гос. тех. ун-та. 2017. Т. 20, № 2. С. 316-325.

Планктон морей Западной Арктики / Отв. ред. Г.Г. Матишов. Апатиты: Изд-во КНЦ РАН, 1997. 352 с.

Сорокин Ю.И., Вшивиев В.С., Домников В.С. Биологическая структура вод, ее изменчивость и состояние гидробионтов // Техногенное загрязнение и процессы естественного самоочищения. - М.: Недра, 1996. С. 266-312.

Трофимов А.Г., Карсаков А.Л., Ившин В.А. Изменения климата в Баренцевом море на протяжении последнего полувека // Тр. ВНИРО. 2018. Т. 173. С. 79-91.

Шавыкин А.А., Ильин Г.В. Оценка интегральной уязвимости Баренцева моря от нефтяного загрязнения. Мурманск: Изд. ММБИ КНЦ РАН, 2010. 110 с.

Широколобова Т.И., Венгер М.П., Бобров К.А. Массовые компоненты микропланктона зоны ледовой кромки Баренцева моря // Тр. Кольского науч. центра РАН. 2017. Т. 2(8). Сер. Океанология. Вып. 4. С. 39-50.

Cottrell M.T., Kirchman D.L. Virus genes in Arctic marine bacteria identified by metagenomic analysis // Aquat. Microb. Ecol. 2012. Vol. 66. P. 107-116.

Distribution of bacterial biomass and activity in the marginal ice zone of the central Barents sea during summer / M.H. Howard-Jones, V.D. Ballard, A.E. Allen et al. // J. Mar. Syst. 2002. Vol. 38. P. 77-91.

Murray A.G., Jackson G.A. Viral dynamics: a model of the effects of singlecelled planktonic organisms and other particles // Mar. Ecol. Progr. Ser. 1992. Vol. 14. P. 113-118.

Noble R.T., Fuhrman J.A. Use of SYBR Green I for rapid epifluorescence counts of marine viruses and bacteria // Aquat. Microb. Ecol. 1998. Vol. 14, № 2. P. 113-118.

Norland $S$. The relationship between biomass and volume of bacteria // Handbook of methods in aquatic microbial ecology. Boca Raton: Lewis Publ., 1993. P. 303-308.

Porter J., Feig Y.S. The use of DAPI for identifying and counting aquatic microflora // Limnol. Oceanogr. 1980. Vol. 25. P. 943-948.

Spatial distribution of viruses, bacteria and chlorophyll a in neritic, oceanic and estuarine environments / W.P. Cochlan, J. Wikner, G.F. Steward et al. // Mar. Ecol. Prog. Ser. 1993. Vol. 92. P. 77-87.

Wells L.E., Deming J.W. Significance of bacterivory and viral lysis in bottom waters of Franklin Bay, Canadian Arctic, during winter // Aquat. Microb. Ecol. 2006. Vol. 45. P. 209-221.

Wommack K.E., Colwell R.R. Virioplankton: viruses in aquatic ecosystems // Microb. Mol. Biol. Rev. 2000. Vol. 64(1). P. 69-114. 
DOI: $10.37614 / 2307-5252.2021 .3 .9 .007$

УДК 598.2

\section{А.Н. Гурба}

Мурманский морской биологический институт РАН, г. Мурманск, Россия

\section{ЗИМНЯЯ АВИФАУНА КОЛЬСКОГО ЗАЛИВА В 2020-2021 гг.}

\section{Аннотация}

Акватория Кольского залива - важное место для морских и околоводных птиц во время осенне-весенних миграций и зимовок. Приведены результаты учетов зимующих птиц в разных частях залива в 2020-2021 гг. Наблюдения выполнены на участках побережья залива с прилегающей акваторией (губа Грязная, район Кольского моста). В целом в южной и средней части Кольского залива наиболее многочисленные виды в зимний период - обыкновенная гага Somateria mollissima, морянка Clangula hyemalis, кряква Anas platyrhynchos и бургомистр Larus hyperboreus. Во время исследований отмечена относительно низкая численность зимующих морских песочников Calidris maritima, чем в предыдущие годы наблюдений. В Кольском заливе состав авифауны в течение зимы достаточно постоянен. Резкие изменения погоды, например потепление, похолодание или метель, могут вызвать лишь небольшие перемещения птиц в пределах зимовочного района.

Ключевые слова: обыкновенная гага, морянка, зимовка, численность, Кольский залив.

\section{A.N. Gurba}

Murmansk Marine Biological Institute RAS, Murmansk, Russia

\section{WINTER BIRD FAUNA OF THE KOLA BAY IN 2020-2021}

\section{Abstract}

The water area of the Kola Bay is an important place for marine and near-water birds during spring-autumn migrations and wintering periods. The results of counts of wintering birds in different parts of the bay in 2020-2021 are presented. The observations were carried out on the coast areas of the bay with the adjacent water area (Gryaznaya Bay, the area of the Kola Bridge). In general, in the southern and middle parts of the Kola Bay, the most numerous species in winter were common eider Somateria mollissima, long-tailed duck Clangula hyemalis, mallard Anas platyrhynchos, and glaucous gull Larus hyperboreus. During the observations, a relatively low nymber of wintering purple sandpipers Calidris maritima was noted in comparison to previous years. The composition of the bird fauna in the Kola Bay is fairly constant during the winter. Abrupt weather changes, such as warming, cooling, or snowstorms, cause only small movements of birds within the wintering area.

Key words: eider, long-tailed duck, wintering, number, Kola Bay. 
Введение. Кольский залив является крупнейшим фьордом побережья Мурмана и испытывает высокую антропогенную нагрузку. Условно акватория залива разделяется на северную, среднюю и южную части (колена). Залив играет важную роль в осенне-весенних миграциях и зимовках морских и околоводных птиц, а берега залива служат местом размножения некоторых из них в летний период благодаря богатой кормовой базе и разнообразию мест для гнездования. В течение многих лет основные представители зимней авифауны - обыкновенная гага, сибирская гага, гага-гребенушка, морянка, кряква, бургомистр, морской песочник (Краснов, Горяев, 2001, 2013; Кольский ..., 2018).

На численность и видовое разнообразие морских и околоводных птиц влияют как внутрипопуляционные процессы, так и антропогенные факторы (в основном беспокойство и загрязнение местообитаний). Для оценки степени происходящих изменений необходимы современные данные о состоянии орнитофауны залива, так как на его акватории и побережье ежегодно обитают многие виды птиц.

Цель работы - определить современный видовой состав, численность и половозрастную структуру птиц в разных частях Кольского залива и проанализировать особенности их размещения в зимний период.

Материал и методы. Учет проводился с 4 ноября 2000 г. по 19 февраля 2021 г. на двух участках побережья с прилегающей акваторией. Первый участок находится в южной части залива, от Кольского моста до авторынка, второй - в средней части залива вдоль губы Грязная (рис. 1).

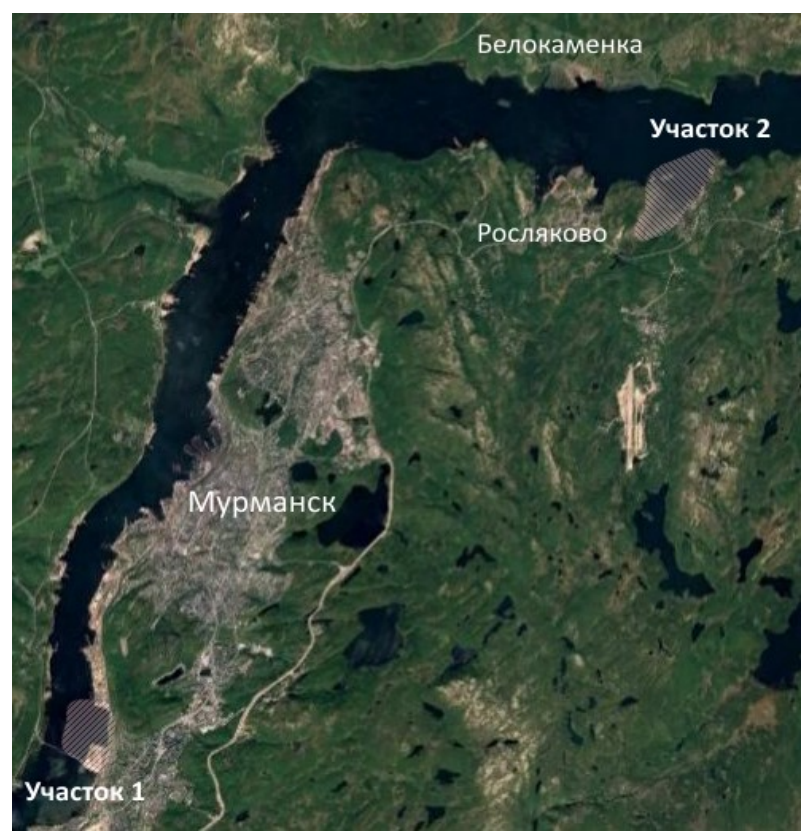

Рис. 1. Карта-схема расположения районов работ: 1 - Кольский мост, 2 - губа Грязная

Fig. 1. Map of the location of work areas: 1 - Kola Bridge, 2 - Gryaznaya Bay 
Длина первого маршрута составила 2 км, второго - 3 км. Площадь акватории, охваченной учетом, на первом участке равна 1.4 км $^{2}$, на втором - 2.1 км $^{2}$. Суммарное время учетов -43 ч. При этом продолжительность наблюдений была разной в связи с полярной ночью и коротким световым днем до и после нее в зимний период. Около $55 \%$ из них велись во время отлива.

Отмечались и подсчитывались птицы по пути маршрута, в воздухе и на акватории водоема (осмотр проводился невооруженным глазом и с помощью 16-кратного бинокля). Также в полевой журнал заносились данные о поведении птиц, погодных и приливоотливных условиях.

Результаты и обсуждение. Всего в ходе работ отмечен 21 вид птиц из 5 отрядов: Anseriformes, Charadriiformes, Columbiformes, Piciformes, Passeriformes (таблица). 11 видов напрямую связаны с водной экосистемой.

Средняя численность и плотность распределения птиц в южной и средней частях Кольского залива в зимний период 2020/21 гг.

Average number and density of distribution of birds found in the southern and the middle parts of the Kola Bay in winter 2020/21

\begin{tabular}{|c|c|c|c|c|}
\hline \multirow[b]{2}{*}{ Вид } & \multicolumn{2}{|c|}{ Губа Грязная } & \multicolumn{2}{|c|}{ Район Кольского моста } \\
\hline & $\begin{array}{l}\text { Численность, } \\
\text { экз. }\end{array}$ & $\mid \begin{array}{c}\text { Плотность } \\
\text { распределения, } \\
\text { экз } / \text { км }^{2}\end{array}$ & $\begin{array}{l}\text { Численность, } \\
\text { экз. }\end{array}$ & $\begin{array}{c}\text { Плотность } \\
\text { распределения, } \\
\text { экз/км }\end{array}$ \\
\hline $\begin{array}{l}\text { Кряква } \\
\text { Anas platyrhynchos }\end{array}$ & - & - & 155 & 74 \\
\hline $\begin{array}{l}\text { Обыкновенная гага } \\
\text { Somateria mollissima }\end{array}$ & 34 & 8 & 340 & 162 \\
\hline $\begin{array}{l}\text { Гага-гребенушка } \\
\text { Somateria spectabilis }\end{array}$ & 5 & 0.3 & 23 & 1 \\
\hline $\begin{array}{l}\text { Синьга } \\
\text { Melanitta nigra }\end{array}$ & - & - & 8 & - \\
\hline $\begin{array}{l}\text { Морянка } \\
\text { Clangula hyemalis }\end{array}$ & - & - & 180 & 86 \\
\hline $\begin{array}{l}\text { Обыкновенный } \\
\text { гоголь Bucephala } \\
\text { clangula }\end{array}$ & - & - & 5 & 0.7 \\
\hline $\begin{array}{l}\text { Морской песочник } \\
\text { Calidris maritima }\end{array}$ & 6 & 1.5 & - & - \\
\hline $\begin{array}{l}\text { Сизая чайка } \\
\text { Larus canus }\end{array}$ & 1 & 0.1 & 6 & 1 \\
\hline $\begin{array}{l}\text { Морская чайка } \\
\text { Larus marinus }\end{array}$ & 1 & 0.3 & 3 & 0.6 \\
\hline $\begin{array}{l}\text { Серебристая чайка } \\
\text { Larus argentatus }\end{array}$ & 2 & 0.3 & 3 & 0.5 \\
\hline $\begin{array}{l}\text { Бургомистр } \\
\text { Larus hyperboreus }\end{array}$ & 45 & 32 & 35 & 17 \\
\hline $\begin{array}{l}\text { Серая ворона } \\
\text { Corvus cornix }\end{array}$ & 29 & 20 & 14 & 7 \\
\hline
\end{tabular}

ПРИМЕЧАНИЕ. Для синьги указана общая численность за все время наблюдений. 
Среди зимующих птиц в 2020/21 гг. преобладали обыкновенная гага, морянка, кряква - типичные водные птицы, и бургомистр в большей степени представитель околоводной фауны. В южной части залива доминировали птицы отряда гусеобразных, а в средней ржанкообразных (чайки и кулики). В общей численности всех учтенных птиц доля морских и околоводных составляет примерно $92 \%$.

Бо́льшая часть крякв из города и близлежащих мест мигрирует на юг, а в заливе остается немногочисленная группировка. Кряквы были отмечены только на южном участке, так как в осенне-зимний период они покидают городские водоемы и предпочитают держаться в распресненных частях залива. Несмотря на то, что бо́льшая часть зимующих в Кольском заливе обыкновенных гаг обычно обитает в его среднем и северном коленах (Краснов, Горяев, 2013), несколько сотен особей все же предпочитают держаться в вершинной части залива, что связано с более спокойными волновыми, ветровыми и благоприятными кормовыми условиями.

Высокая численность бургомистров в губе Грязная обусловлена ее мелководностью, так как во время отлива обнажаются обширные участки литорали, которые птицы используют для поиска пищи и отдыха (рис. 2).

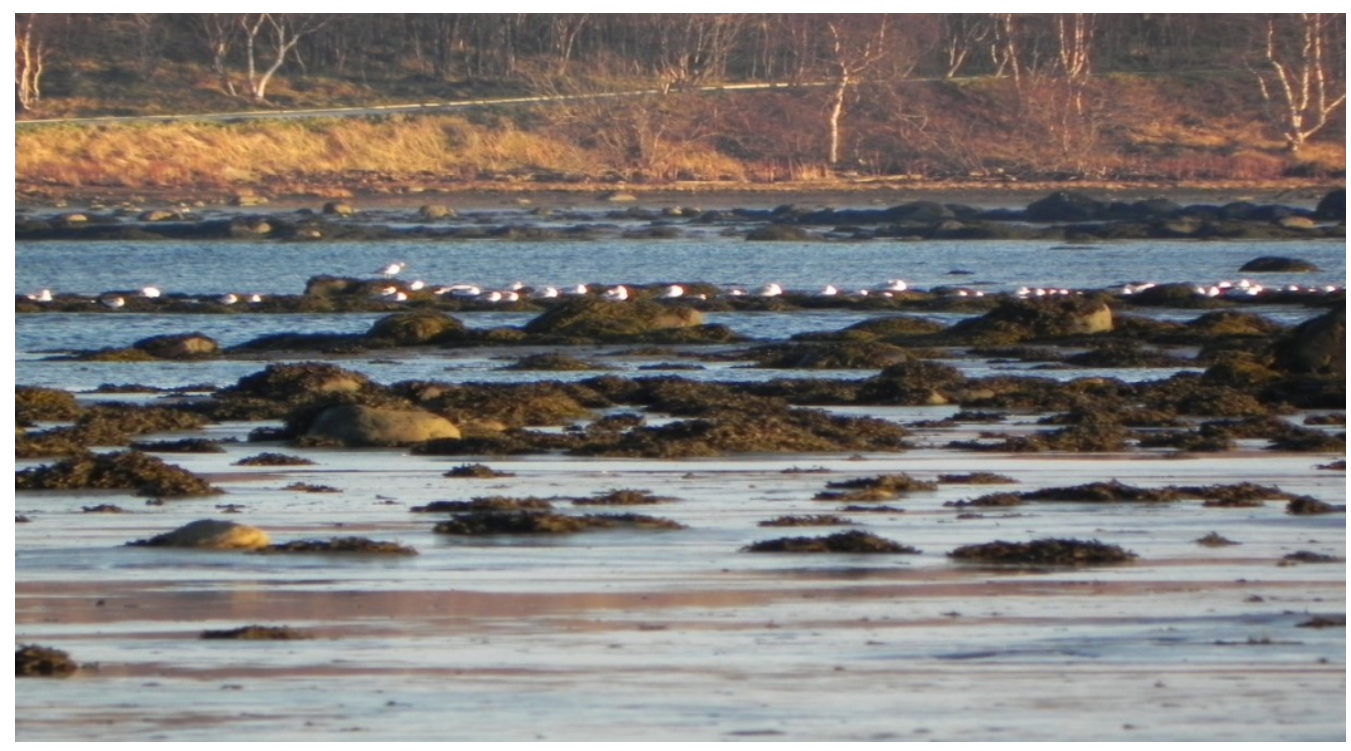

Рис. 2. Скопление бургомистров во время отлива на участке литорали в губе Грязная

Fig. 2. Flock of glaucous gulls at low tide in the littoral area in Gryaznaya Bay

По данным предыдущих лет (Краснов, Гаврило, 2009) в исследуемых районах, как и на всем побережье Кольского залива, на зимовках присутствовали в большом количестве морские песочники, однако во время наших наблюдений их численность была гораздо меньше. Такие 
результаты могут быть обусловлены относительно небольшой площадью свободной от льда литорали, а также недоучетом этих птиц из-за плохой видимости и короткого светового дня во время полярной ночи, который не всегда совпадал с отливом.

На акватории Кольского залива обыкновенные гаги и морянки наблюдались стаями от 100 особей и более. Морянки при этом не образовывали достаточно плотных скоплений и держались рассеянно по акватории. В воздухе чайки встречались по одной, но в водоеме и на литорали могли образовывать группы численностью до нескольких десятков особей. Так, в губе Грязная на участке каменистой литорали было обнаружено место отдыха бургомистров, где во время отлива они собирались по 60-70 особей. В течение периода наблюдений там находились как половозрелые птицы в зимнем оперении, так и молодые разного возраста.

Следует отметить, что во время отлива побережье и литораль залива активно используются серыми воронами в качестве кормовой стации. При этом численность этих птиц на участке может достигать 50 особей.

Группа из восьми особей синьги была встречена 5 декабря 2020 г., они держались неподалеку от скопления обыкновенных гаг в районе Кольского моста.

Доля самцов и самок обыкновенной гаги составила 55.4 и $44.6 \%$ соответственно, кряквы - 53.2 и $46.8 \%$, морянки - 48.8 и $51.2 \%$. У чайковых птиц молодые особи составили $37.5 \%$ от общего числа. У остальных видов птиц определить половозрастную структуру не удалось.

Относительное обилие птиц для южной части залива составило в среднем 783 особи/км², для губы Грязная - 233 особи/км². Индекс видового богатства выше в губе Грязная и равен 0.05 (возможно, за счет большего количества видов воробьинообразных, что связано с близостью лесной зоны на этом участке наблюдений). Для района Кольского моста значения данного индекса равны 0.013 .

Заключение. Во время наблюдений на территории Кольского залива состав авифауны в течение зимы был достаточно постоянен. Резкие изменения погоды, например потепление, похолодание или метель, вызывали лишь небольшие перемещения зимующих птиц в пределах изучаемого района.

Работа была выполнена в рамках государственного задания.

\section{Литература}

Кольский залив и нефть: биота, карты уязвимости, загрязнение / Под ред. д-ра геогр. наук А.А. Шавыкина. СПб.: Реноме, 2018. 520 с.

Краснов Ю.В., Гаврило М.В. О зимовке морского песочника Calidris maritima на побережьях Кольского полуострова // Кулики Северной Евразии: экология, миграция и охрана: Тез. докл. VIII Междунар. науч. конф. (10-12 ноября 2009 г., Ростов-на-Дону). Ростов н/Д.: Изд-во ЮНЦ РАН, 2009. С. 79-80. 
Краснов Ю.В., Горяев Ю.И. Сезонная динамика морских водоплавающих птиц в прибрежных водах Мурмана // Биологические основы устойчивого развития прибрежных морских экосистем: Тез. докл. Междунар. конф. (г. Мурманск, 2528 апреля 2001 г.). Апатиты: Изд-во КНЦ РАН, 2001. С. 116-118.

Краснов Ю.В., Горяев Ю.И. Основные тенденции развития авифауны Кольского залива и факторы его определяющие // Птицы северных и южных морей России: фауна, экология. Апатиты: Изд-во КНЦ РАН, 2013. С. 38-64.

DOI: 10.37614/2307-5252.2021.3.9.008

УДК 574.587:594.7

О.Ю. Евсеева

Мурманский морской биологический институт РАН, г. Мурманск, Россия

\section{МШАНКИ (ВRYOZOA) МOРЕЙ ЛАПТЕВЫХ И ВОСТОЧНО-СИБИРСКОГО: СОВРЕМЕННЫЕ ИССЛЕДОВАНИЯ}

\section{Аннотация}

Получены новые данные по фрауне Bryozoa сибирских морей (Лаптевых и ВосточноСибирского). В пробах, собранных в экспедиции ММБИ КНЦ РАН (2014 г.) на 50 станциях, идентифицировано 48 видов Bryozoa: 45 - в море Лаптевых и 16 в Восточно-Сибирском. Проанализирован таксономический и биогеографический состав мшанок, а также особенности их распределения. Проведен сравнительный анализ исследований конца XX века (1986, 1987 и 1993-1998 гг.) по литературным данным (Гонтарь, 1990, 1994, 2004, 2015а,б, 2016). Отмечено значительное увеличение доли бореально-арктических видов вследствие существенного уменьшения арктических (почти на треть), что, вероятно, отражает изменение климата в сторону потепления, наблюдаемого в начале XXI века.

Ключевые слова: мшанки, Bryozoa, колонии, зоарий, условия среды, сибирские моря, море Лаптевых, Восточно-Сибирское море.

\section{O.Yu. Evseeva}

Murmansk Marine Biological Institute RAS, Murmansk, Russia

\section{BRYOZOA OF THE LAPTEV AND EAST SIBERIAN SEAS: MODERN RESEARCH}

\section{Abstract}

The new data about bryozoan fauna of the Siberian seas (Laptev Sea and East Siberian Sea) are obtained. 48 species of Bryozoa were identified in the samples, collected in the MMBI RAS expedition (2014) at 50 stations: 45 - in the Laptev Sea and 16 - in the East Siberian Sea. The taxonomic and biogeographic composition, the features of distribution of Bryozoa are analyzed. A comparative analysis of the studies of the end of the $20^{\text {th }}$ century $(1986,1987$ and 1993-1998) based on literature data is carried out (Gontar, 1990, 1994, 2004, 2015а,6, 2016). There was a significant increase 
in the share of boreal-arctic species due to a significant decrease of arctic species (by almost a third), which probably reflects the climate change towards warming, observed at the beginning of the $21^{\text {st }}$ century.

Keywords: Bryozoa, colonies, zoary, environment conditions, Siberian seas, Laptev Sea, East Siberian Sea.

Введение. История изучения донных биоценозов наиболее труднодоступных сибирских морей - Лаптевых и Восточно-Сибирского началась более 140 лет назад. Эти окраинные моря Северного Ледовитого океана большую часть года покрыты льдом, характеризуются низкой температурой воды (около $0^{\circ}$ ) и занимают обширные участки материковой отмели (с глубинами в среднем до 50 м).

В море Лаптевых преобладают поверхностные арктические воды с сезонным расслоением по температуре и солености. Изменение температуры с глубиной наблюдается исключительно в летние месяцы, зимой на мелководьях (50-60 м) температура воды от поверхности до дна одинаковая. Соленость варьирует в широких пределах - от 1 до 34 \%о, но преобладают воды с соленостью 20-30 \%. В западную часть моря Лаптевых вдается глубокий желоб, по которому в море проникают более теплые и соленые воды. Наибольшая соленость наблюдается в северозападной части моря, куда с севера заходят более соленые воды. В юговосточной части моря отмечена максимальная придонная соленость $30.5 \%$ (Гуков, 2013). С увеличением глубины соленость повышается до 33 \%. Сильное влияние на величину солености оказывают речной сток и таяние льда (Гонтарь, 2015б). На мелководье (до 50 м) преобладают песчано-илистые грунты. Основная площадь шельфа моря Лаптевых (глубина от 50 до 100 м) покрыта илами. В прибрежных районах формируются глинистые и песчанистые илы (Белов, 1967; Гуков, 2013).

Восточно-Сибирское море - одно из самых мелководных арктических морей. Почти 96 \% площади моря приходится на глубины до 200 м, а вся северо-западная часть моря полностью расположена в пределах шельфа. Восточно-Сибирское море находится под воздействием разных типов водных масс. Это теплые воды пониженной солености, теплые воды повышенной солености и холодные воды высокой солености. Основное поступление пресных вод в море осуществляется с юга. Кроме этого, распресненные воды (трансформированные воды рек) поступают в западные районы Восточно-Сибирского моря из моря Лаптевых. Температура воды в придонном слое даже летом имеет отрицательные значения. Соленость воды постепенно увеличивается с глубиной. Так на глубине 50 м соленость составляет 30-34 \%о, а на 200 м - 34.5\%о. В центральном и прибрежном районах моря распространены илистоглинистые, а в восточной части - илисто-песчаные донные осадки (Ионин и др., 1987; Гуков, 2013). 
Фауна Bryozoa сибирских морей формируется под влиянием арктических и солоноватоводных условий среды. Согласно литературным данным (Гонтарь, 2015а,б), мшанки играют значительную роль в биоценозах моря Лаптевых и часто оказываются доминирующей группой в фауне. Небольшая численность видов отмечена на мелководье (на глубинах менее 25 м) по причине низкой солености воды, но с увеличением глубины, а следовательно, и солености, количество видов возрастает (Гонтарь, 2016).

Несмотря на достаточно полную изученность фауны сибирских морей, целесообразность мониторинга биоразнообразия остается актуальной, особенно в условиях наблюдаемых климатических изменений.

Материал и методы. Материалом для данной работы послужили мшанки из проб зообентоса, собранные в экспедиции Мурманского морского биологического института на НИС “Дальние Зеленцы” в августе-октябре 2014 г. в морях Лаптевых и Восточно-Сибирском (рисунок, табл. 1). Пробы отбирались на глубине от 10 до 100 м тралом Сигсби и из приловов рыбного донного трала. Таксономическая идентификация проводилась автором с использованием определителей мшанок северных морей (Клюге, 1962; Kluge, 2009) и с учетом современной классификации.

Биогеографический анализ проводился по классификации, предложенной в работе В.И. Гонтарь и Н.В. Денисенко (Gontar, Denisenko, 1989).

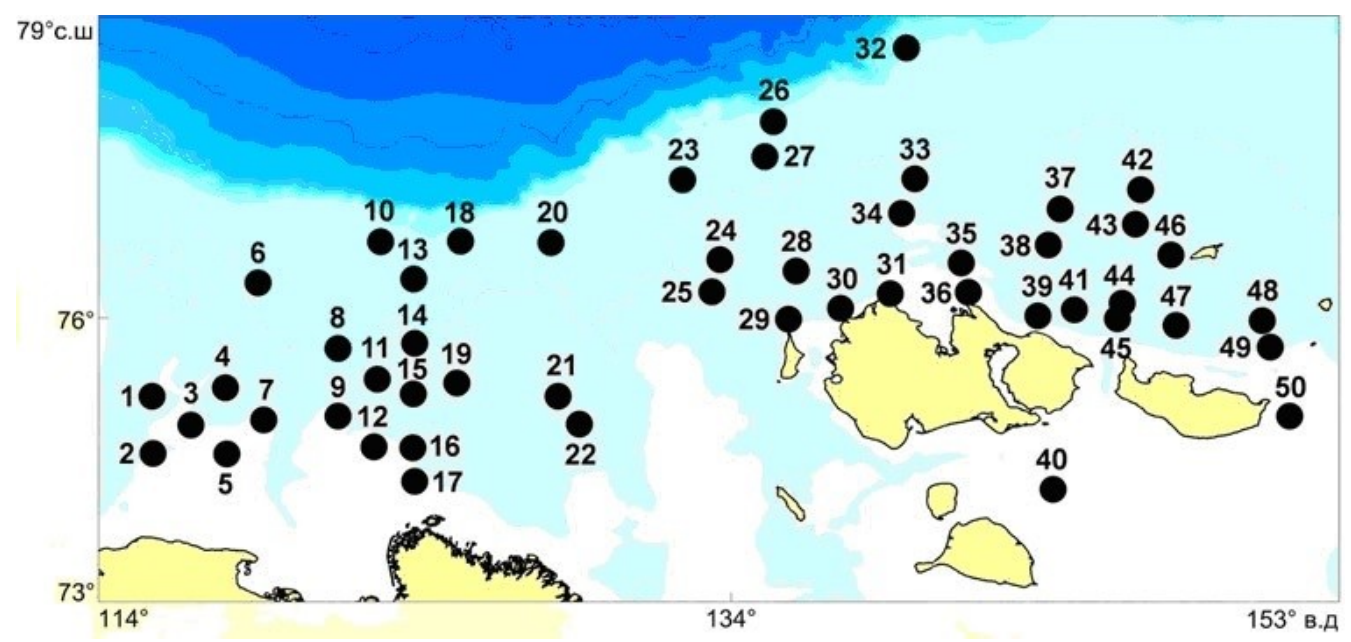

Карта-схема района исследований и отбора проб зообентоса в морях Лаптевых и Восточно-Сибирском в августе-октябре 2014 г.

Map of the zoobenthos research and sampling area in the Siberian Laptev and East Siberian seas in August-October 2014 
Т а блица 1

Характеристика станций в районах исследований

Characteristics of stations in the research areas

\begin{tabular}{|c|c|c|c|c|c|}
\hline $\begin{array}{c}\text { Номер } \\
\text { станции } \\
\end{array}$ & \begin{tabular}{|c|} 
Глубина, \\
м
\end{tabular} & $\mathrm{T},{ }^{\circ} \mathrm{C}$ & S, \%o & $\begin{array}{c}\text { Количество } \\
\text { видов }\end{array}$ & $\begin{array}{c}\text { Доминирующий } \\
\text { вид }\end{array}$ \\
\hline \multicolumn{6}{|c|}{ Море Лаптевых } \\
\hline 1 & 21 & 2.02 & 32.69 & 2 & $\begin{array}{l}\text { Diplosolen obelium arcticum, } \\
\text { Tegella armifera }\end{array}$ \\
\hline 2 & 15 & 2.18 & 30.16 & 13 & $\begin{array}{l}\text { Alcyonidium radicellatum, } \\
\text { Dendrobeania flustroides, } \\
\text { Eucratea loricata, } \\
\text { Serratiflustra serrulata }\end{array}$ \\
\hline 3 & 18 & 2.47 & 32.00 & 2 & Eucratea loricata \\
\hline 4 & 25 & 0.99 & 33.81 & 3 & Leieschara subgracilis \\
\hline 5 & 19 & 2.23 & 32.62 & 1 & Flustra nordenskjoldi \\
\hline 6 & 54 & -1.52 & 34.17 & 3 & Serratiflustra serrulata \\
\hline 7 & 23 & 2.50 & 33.14 & 1 & Dendrobeania levinseni \\
\hline 8 & 58 & -1.66 & 34.45 & 29 & $\begin{array}{l}\text { Dendrobeania levinseni, } \\
\text { Flustra nordenskjoldi, } \\
\text { Pseudoflustra solida, } \\
\text { Serratiflustra serrulata }\end{array}$ \\
\hline 9 & 19 & 0.92 & 33.72 & 8 & $\begin{array}{l}\text { Flustra nordenskjoldi, } \\
\text { Serratiflustra serrulata }\end{array}$ \\
\hline 10 & 94 & -1.77 & 34.41 & 2 & $\begin{array}{l}\text { Alcyonidium disciforme, } \\
\text { Alcyonidium gelatinosum }\end{array}$ \\
\hline 11 & 46 & -1.67 & 34.76 & 3 & $\begin{array}{l}\text { Serratiflustra serrulata, } \\
\text { Flustra nordenskjoldi }\end{array}$ \\
\hline 12 & 10 & 2.09 & 31.64 & 2 & Serratiflustra serrulata \\
\hline 13 & 65 & -1.69 & 34.62 & 2 & $\begin{array}{l}\text { Alcyonidium disciforme, } \\
\text { Alcyonidium gelatinosum }\end{array}$ \\
\hline 14 & 44 & -1.74 & 34.70 & 10 & $\begin{array}{l}\text { Bugula fastigiata, } \\
\text { Flustra nordenskjoldi, } \\
\text { Serratiflustra serrulata }\end{array}$ \\
\hline 15 & 41 & - & - & 1 & Alcyonidium radicellatum \\
\hline 16 & 28 & - & - & 2 & Serratiflustra serrulata \\
\hline 17 & 13 & 2.76 & 29.06 & 1 & Serratiflustra serrulata \\
\hline 18 & 76 & -1.77 & 34.66 & 2 & $\begin{array}{l}\text { Alcyonidium disciforme, } \\
\text { Alcyonidium gelatinosum }\end{array}$ \\
\hline 19 & 37 & -1.63 & 34.56 & 1 & Alcyonidium gelatinosum \\
\hline 20 & 63 & -1.81 & 34.72 & 1 & Alcyonidium disciforme \\
\hline 21 & 37 & -1.50 & 33.69 & 1 & Alcyonidium disciforme \\
\hline 22 & 37 & -1.53 & 33.87 & 1 & Eucratea loricata \\
\hline 23 & 58 & -1.52 & 34.28 & 2 & $\begin{array}{l}\text { Arctonula arctica, } \\
\text { Turbicellepora canaliculata }\end{array}$ \\
\hline 24 & 32 & -1.46 & 32.92 & 1 & Alcyonidium gelatinosum \\
\hline 25 & 37 & -1.51 & 33.69 & 1 & Alcyonidium disciforme \\
\hline 26 & 69 & -1.38 & 34.34 & 7 & $\begin{array}{l}\text { Alcyonidium disciforme, } \\
\text { Serratiflustra serrulata }\end{array}$ \\
\hline 27 & 54 & -0.95 & 34.05 & 1 & Alcyonidium radicellatum \\
\hline 28 & 21 & 1.67 & 29.66 & 3 & $\begin{array}{l}\text { Eucratea loricata, } \\
\text { Flustra nordenskjoldi }\end{array}$ \\
\hline 29 & 20 & - & - & 2 & $\begin{array}{l}\text { Alcyonidium disciforme, } \\
\text { Alcyonidium gelatinosum }\end{array}$ \\
\hline
\end{tabular}


Окончание табл. 1

\begin{tabular}{|c|c|c|c|c|c|}
\hline $\begin{array}{c}\text { Номер } \\
\text { станции }\end{array}$ & \begin{tabular}{|c|} 
Глубина, \\
м
\end{tabular} & $\mathrm{T},{ }^{\circ} \mathrm{C}$ & $\mathrm{S}, \%$ & $\begin{array}{l}\text { Количество } \\
\text { видов }\end{array}$ & $\begin{array}{l}\text { Доминирующий } \\
\text { вид }\end{array}$ \\
\hline 30 & 19 & 2.73 & 25.25 & 1 & Alcyonidium disciforme \\
\hline 31 & 16 & - & - & 3 & Tegella armifera \\
\hline \multicolumn{6}{|c|}{ Восточно-Сибирское море } \\
\hline 32 & 101 & -1.06 & 34.29 & 1 & Alcyonidium gelatinosum \\
\hline 33 & 34 & 0.28 & 31.09 & 1 & Alcyonidium disciforme \\
\hline 34 & 18 & 3.96 & 26.24 & 3 & Alcyonidium gelatinosum \\
\hline 35 & 12 & 3.99 & 23.14 & 4 & $\begin{array}{l}\text { Alcyonidium gelatinosum, } \\
\text { Eucratea loricata }\end{array}$ \\
\hline 36 & 10 & - & - & 1 & Alcyonidium disciforme \\
\hline 37 & 39 & -1.12 & 30.27 & 7 & $\begin{array}{l}\text { Flustra nordenskjoldi, } \\
\text { Porella compressa, } \\
\text { Terminoflustra } \\
\text { membranaceotruncata }\end{array}$ \\
\hline 38 & 35 & -1.03 & 29.11 & 1 & Alcyonidium disciforme \\
\hline 39 & 30 & -0.47 & 28.67 & 2 & Alcyonidium gelatinosum \\
\hline 40 & 31 & 3.15 & 30.27 & 1 & Alcyonidium gelatinosum \\
\hline 41 & 36 & - & - & 4 & $\begin{array}{l}\text { Alcyonidium gelatinosum, } \\
\text { Eucratea loricata }\end{array}$ \\
\hline 42 & 38 & -0.82 & 29.76 & 6 & $\begin{array}{l}\text { Flustra nordenskjoldi, } \\
\text { Serratiflustra serrulata }\end{array}$ \\
\hline 43 & 31 & -0.91 & 29.17 & 1 & Serratiflustra serrulata \\
\hline 44 & 35 & -1.24 & 29.86 & 1 & Serratiflustra serrulata \\
\hline 45 & 33 & - & - & 5 & $\begin{array}{l}\text { Alcyonidium gelatinosum, } \\
\text { Eucratea loricata, } \\
\text { Serratiflustra serrulata }\end{array}$ \\
\hline 46 & 36 & -1.17 & 29.95 & 2 & Alcyonidium gelatinosum \\
\hline 47 & 30 & -0.71 & 29.34 & 2 & Alcyonidium gelatinosum \\
\hline 48 & 30 & -0.70 & 29.16 & 1 & Alcyonidium gelatinosum \\
\hline 49 & 22 & 1.92 & 27.50 & 1 & Alcyonidium gelatinosum \\
\hline 50 & 13 & - & - & 1 & Alcyonidium gelatinosum \\
\hline
\end{tabular}

Результаты и обсуждение. В материале, собранном в море Лаптевых (станции 1-31, 31 проба) и северо-западной части Восточно-Сибирского моря (станции 32-50, 19 проб), идентифицировано 48 видов Bryozoa, относящихся к 3 отрядам, 24 семействам, 34 родам. Из них 45 видов зарегистрировано в море Лаптевых (табл. 2), или $23 \%$ от общего числа мшанок (195 видов), известных в настоящее время для данного водоема (Гонтарь, 1990, 2004, 2015а,б, 2016; Kluge, 2009) и 16 видов отмечено в Восточно-Сибирском море (табл. 2), что составляет $16 \%$ от общего числа мшанок (100 видов) известных для этого район (Гонтарь, 1994; Денисенко, 2010).

Распределение мшанок в районе исследований главным образом зависит от структуры грунта (распространены мягкие илисто-глинистопесчаные донные осадки) и интенсивности гидродинамики (прибойности, течений), что влияет также на тип и форму зоария. Максимальное количество видов (29) было отмечено в море Лаптевых в районе (ст. 8) с повышенным содержанием в грунте грубообломочного материала 
(гальки) на глубине 58 м (рис. 1, табл. 1). В море Лаптевых более половины (58 \%, 26 видов), а в Восточно-Сибирском - три четверти (75\%, 12 видов) обнаруженных представителей мшанок имеют ветвистокустистую форму колонии. Мшанки с приподнятой над субстратом формой зоария развиваются в основном в биотопах с интенсивным осадконакоплением и умеренной гидродинамикой.

Т а бли ц а 2 Видовой состав Bryozoa на станциях в районах исследований

Table 2

Species of Bryozoa composition in the research areas

\begin{tabular}{c|c}
\hline Вид & \\
\hline Alcyonidium disciforme Smitt, 1872 & хар
\end{tabular}

Alcyonidium gelatinosum (Linnaeus, 1761)

Alcyonidium radicellatum Kluge, 1946 Arctonula arctica (M. Sars, 1851) Aquiloniella paenulata (Norman, 1903) Bugula fastigiata Kluge, 1929 Bugulopsis peachii (Busk, 1851) Buffonellaria arctica Berning \& Kuklinski, 2008

Callopora craticula (Alder, 1856) Callopora lineata (Linnaeus, 1767) Cauloramphus cymbaeformis (Hincks, 1877) Celleporella hyalina (Linnaeus, 1767) Celleporina nordenskjoldi (Kluge, 1929) Cheilopora sincera (Smitt, 1867)

Corynoporella tenuis Hincks, 1888

Crisia eburneodenticulata Smitt ms in Busk, 1875

Crisia klugei Ryland, 1967

Crisularia harmsworthi (Waters, 1900)

Dendrobeania decorata (Verrill, 1879)

Dendrobeania flustroides (Levinsen, 1887)

Dendrobeania levinseni (Kluge, 1929)

Diplosolen obelium arcticum (Waters, 1904)

Disporella hispida (Fleming, 1828)

Escharella ventricosa (Hassall, 1842)

Eucratea loricata (Linnaeus, 1758)

Flustra nordenskjoldi Kluge, 1929

\begin{tabular}{c|c|c}
$\begin{array}{c}\text { Биогеогра- } \\
\text { фическая } \\
\text { характеристика }\end{array}$ & $\begin{array}{c}\text { Море } \\
\text { Лаптевых }\end{array}$ & $\begin{array}{c}\text { Восточно- } \\
\text { Сибирское } \\
\text { море }\end{array}$ \\
\hline A $10,13,18$, & $33,36,38$
\end{tabular}

$20,21,25$, $26,29,30$, 31

Б-a $\quad 10,13,18, \quad 32,34,35$, 19, 24, $29 \quad 39,40,41$, $45,46,47$, $48,49,50$

$\begin{array}{clr}\text { А } & 2,15,27 & - \\ \text { Б-a } & 8,23,31 & - \\ \text { Б-a } & - & 35 \\ \text { Б-a } & 4,9,11,14 & - \\ \text { Б-a } & 4,8,9,26 & 42,45 \\ \text { Б-a } & 8 & - \\ & & \\ \text { Б-a } & 2,9,14 & - \\ \text { Б-a } & 8,14 & - \\ \text { Б-a } & 2 & - \\ \text { Б-а } & 9 & - \\ \text { Б-a } & 8 & - \\ \text { Б-a } & 8 & - \\ \text { Б } & 26 & - \\ \text { А } & 8,26 & -\end{array}$

$\begin{array}{cllll}\text { A } & 8 & & \\ \text { A } & 8 & & \\ \text { Б-a } & 8 & & & - \\ \text { Б-a } & 2 & & & - \\ \text { A } & 7,8,14 & 46 & \\ \text { Б-a } & 1,2,8 & & - \\ \text { Б-a } & 2 & & & - \\ \text { Б-a } & & - & 37 & \end{array}$

Б-a $\quad 2,3,6,8,22,34,35,41$, $28 \quad 42,45,47$

b-a $\quad 2,3,5,8,9,37,42$ $11,14,28$ 
Окончание табл. 2

\begin{tabular}{|c|c|c|c|}
\hline Вид & \begin{tabular}{|c|} 
Биогеогра- \\
фическая \\
характеристика
\end{tabular} & $\begin{array}{c}\text { Море } \\
\text { Лаптевых }\end{array}$ & $\begin{array}{c}\text { Восточно- } \\
\text { Сибирское } \\
\text { море }\end{array}$ \\
\hline $\begin{array}{l}\text { Hippoporina reticulatopunctata (Hincks, } \\
\text { 1877) }\end{array}$ & b-a & 2,8 & - \\
\hline Kinetoskias arborescens Danielssen, 1868 & Б-a & 8 & 37 \\
\hline Leieschara subgracilis (d'Orbigny, 1853) & Б-а & 4 & - \\
\hline Patinella multicentra (Kluge, 1955) & A & $2,9,14$ & - \\
\hline Patinella verrucaria (Linnaeus, 1758) & Б-а & 2,26 & - \\
\hline Pleuronea fenestrata (Busk, 1859) & A & 8 & - \\
\hline Porella compressa (J. Sowerby, 1805) & Б-a & - & 37 \\
\hline Porella fragilis Levinsen, 1914 & Б-а & 8 & - \\
\hline Porella proboscidea Hincks, 1888 & A & 9 & - \\
\hline Proboscina incrassata Smitt, 1867 & Б-а & 8 & - \\
\hline Pseudoflustra solida (Stimpson, 1854) & A & 8 & - \\
\hline Rhamphostomella bilaminata (Hincks, 1877) & A & 8 & - \\
\hline $\begin{array}{l}\text { Rhamphostomella scabra (O. Fabricius, } \\
\text { 1780) }\end{array}$ & Б-a & 16 & 42 \\
\hline Serratiflustra serrulata (Busk, 1880) & A & $\begin{array}{l}2,6,8,9,11, \\
12,14,16, \\
17,26,28\end{array}$ & $\begin{array}{l}34,35,39 \\
41,42,43, \\
44,45\end{array}$ \\
\hline Schizoporella crustacea (Smitt, 1868) & Б-a & 8,14 & - \\
\hline Tegella armifera (Hincks, 1880) & Б-a & $\begin{array}{l}1,2,8,12 \\
14,31\end{array}$ & 45 \\
\hline $\begin{array}{l}\text { Terminoflustra membranaceotruncata } \\
\text { (Smitt, 1868) }\end{array}$ & Б-a & 8 & 37,41 \\
\hline Tricellaria gracilis (Van Beneden, 1848) & Б-а & 8,26 & - \\
\hline Tubulipora flabellaris (O. Fabricius, 1780) & Б-a & 8 & - \\
\hline Tubulipora soluta Kluge, 1946 & A & 8 & 37 \\
\hline Tubulipora ventricosa Busk, 1855 & Б-а & 8 & - \\
\hline Turbicellepora canaliculata (Busk, 1881) & A & 14,23 & 37,42 \\
\hline
\end{tabular}

ПРИМЕЧАНИЕ: Б-а - бореально-арктический, А - арктический, Б - бореальный вид.

По литературным данным, в сибирских морях, в частности в море Лаптевых в условиях пониженной солености, одними из самых массовых видов Bryozoa являются необызвествленные (мягкотелые) виды рода Alcyonidium - A. disciforme Smitt, 1872 и A. gelatinosum (Linnaeus, 1761) (Гонтарь, 1990, 2004, 2015a,б, 2016). Это подтверждает гипотезу о том, что низкая соленость в сочетании с низкой температурой воды благоприятствуют развитию мягкотелых видов, так как затрудняется извлечение беспозвоночными кальция из воды (Ахметчина, 2018), что тормозит развитие известковых мшанок. Так в исследуемом материале мягкотелые виды мшанок встретились практически во всех пробах (табл. 2).

Биогеографическая структура фауны региона отражает условия среды (главным образом, температуры), в которой данная фауна формировалась. Наблюдаемое в последние годы потепление в Арктике позволяет изучать влияние водных масс различного происхождения на 
формирование структуры сообществ донных беспозвоночных (в частности, мшанок) и прогнозировать последующие изменения. Так в течение XX и начале XXI веков в Арктике был выявлен ряд теплых и холодных периодов. Например, в Баренцевом море в 1960-1980-е годы наблюдался период похолодания, который сменился периодом потепления (Океанографические ..., 2004), продолжающимся в настоящее время.

Согласно литературным данным (Гонтарь, 1994, 2004, 2016), в 1986, 1987 и 1993-1998 гг. в рассматриваемых сибирских морях зарегистрирована высокая доля арктических видов Bryozoa - 37 \%. При этом в море Лаптевых было выявлено 44 \% (Гонтарь, 2004, 2015а,б, 2016), а в Восточно-Сибирском - 42 \% (Гонтарь, 1994; Денисенко, 2010) арктических видов. Доля бореальных представителей для двух морей в 1986, 1987 и 1993-1998 гг. - 8 \%, в море Лаптевых - 5 \%, ВосточноСибирском - 3\%, а бореально-арктических - 55, 50 и 55 соответственно.

В исследованиях 2014 г. для этих морей отмечено арктических видов $29 \%$, бореальных - $2 \%$, бореально-арктических - $69 \%$, из них в море Лаптевых зарегистрировано арктических видов $31 \%$, бореальных $2 \%$, бореально-арктических - $67 \%$, а в Восточно-Сибирском - $31 \%$ арктических видов и 69 \% бореально-арктических. Бореальные виды отсутствовали. Следовательно, за последние 20 лет доля арктических видов в морях Лаптевых и Восточно-Сибирском сократилась на 13 и 11 \% соответственно, а бореально-арктических видов мшанок увеличилась.

Заключение. В материале, собранном в экспедиции Института в сибирских морях (Лаптевых и северо-западной части ВосточноСибирского моря) в 2014 г., зарегистрировано 48 видов мшанок, на распределение и обилие которых влияет, главным образом, характер грунта. Так, максимальное число видов (29) отмечено в биотопе с повышенным содержанием твердых субстратов (на глубине 58 м в море Лаптевых).

В районе исследований отмечено повышенное (по сравнению с другими регионами арктических морей) обилие необызвествленных (мягкотелых) видов рода Alcyonidium (встретились практически во всех пробах). Это подтверждает гипотезу, что в условиях пониженной солености и низкой температуры воды затрудняется извлечение беспозвоночными кальция из воды (Ахметчина, 2018), что тормозит развитие известковых мшанок, но, вероятно, благоприятно для развития мягкотелых видов.

Сравнительный анализ биогеографической структуры современной фауны мшанок с литературными сведениями демонстрирует заметное увеличение доли арктическо-бореальных видов за счет существенного уменьшения (на треть) доли арктических видов, что объясняется влиянием потепления климата, наблюдаемого за прошедший период (около 20 лет). 


\section{Литература}

Ахметчина О.Ю. Исследование факторов среды, влияющих на наличие и распределение мшанок // Исследования арктических экосистем: Матер. XXXVI конф. молодых ученых ММБИ КНЦ РАН, посвященной 40-летию научноисследовательского судна “Дальние Зеленцы”. Мурманск: Изд. ММБИ КНЦ PAH, 2018. C. 12-18.

Белов Н.А. Гранулометрический и вещественный состав взвеси моря Лаптевых // Тр. ААНИИ. 1967. Т. 278. С. 142-146.

Океанографические условия / В.Д. Бойцов, В.В. Терещенко, А.Л. Корсаков, Г.И. Несветова // Исследования ПИНРО в районе архипелага Шпицберген. Мурманск: Изд-во ПИНРО, 2004. С. 42-67.

Гонтарь В.И. Мшанки (Bryozoa) моря Лаптевых и Новосибирского мелководья // Экосистемы Новосибирского мелководья и фауна моря Лаптевых и сопредельных вод. Л.: Наука, 1990. С. 130-138 (Исследования фауны морей. T. 37(45).

Гонтарь В.И. Распределение и экология мшанок (Bryozoa) в прибрежных водах Чаунской губы Восточно-Сибирского моря // Исследования фауны морей. Л.: Наука, 1994. Т. 47(55). С. 144-147.

Гонтарь В.И. Список видов беспозвоночных моря Лаптевых и прилежащих акваторий, составленный по материалам последних экспедиций 90 -х годов XX столетия. Bryozoa // Фауна и экосистема моря Лаптевых и сопредельных глубоководных участков Арктического бассейна. Вып. 54(62). Часть II. СПб.: Изд. Зоол. ин-та РАН, 2004. С. 151-156.

Гонтарь В.И. Донная фауна и экология мшанок моря Лаптевых // Человек и Север: Антропология, археология, экология: Матер. Всерос. конф. Вып. 3 . Тюмень: ИПОС СО РАН, 2015а. С. 315-318.

Гонтарь В.И. Донная фауна и экология мшанок моря Лаптевых // Национальная Ассоциация Ученых. 2015б. № 3-6(8). С. 93-102.

Гонтарь В.И. Донная фауна и экология мшанок моря Лаптевых // Влияние науки на инновационное развитие: Сб. статей междунар. науч.-практ. конф. Пермь: НИЦ-Аэтерна, 2016. С. 12-20.

Гуков А.Ю. Экология донных биоценозов морей Лаптевых и ВосточноСибирского: Дис. ... докт. биол. наук (03.02.08). Якутск: ГОУВПО Якутский гос. ун-т, 2013. $417 \mathrm{c.}$

Денисенко Н.В. Мшанки Восточно-Сибирского моря // Фауна ВосточноСибирского моря, закономерности развития и количественное распределение донных сообществ // Исследования фауны морей. СПб.: Изд. Зоол. ин-та РАН, 2010. Вып. 66(74). С. 89-129.

Ионин А.С., Медведев В.С., Павлидис Ю.А. Шельф: рельеф, осадки и их формирование. М.: Мысль, 1987. 207 с.

Клюге Г.А. Мшанки северных морей СССР. М.; Л.: Изд-во АН СССР, 1962. $584 \mathrm{c}$.

Gontar V.I., Denisenko N.V. Arctic Ocean Bryozoa // The Arctic Seas. Climatology, oceanography, geology and biology. New York, 1989. P. 341-373.

Kluge $H$. Ecology and distribution of Bryozoa in the Barents Sea and in the Siberian seas. Saint Petersburg: LULU Inc., 2009. 216 p. 
DOI: 10.37614/2307-5252.2021.3.9.009

УДК $542.06+577.1$

Л.В. Захарова, Е.Д. Облучинская

Мурманский морской биологический институт РАН, г. Мурманск, Россия

\title{
ПОЛИФЕНОЛЫ И АНТИОКСИДАНТНАЯ АКТИВНОСТЬ ЭКСТРАКТОВ ФУКУСОВЫХ ВОДОРОСЛЕЙ ЗАЛИВА ФАКСАФЛОУИ (МОРЕ ИРМИНГЕРА) И БУХТЫ ЗАВАЛИШИНА (БАРЕНЦЕВО МОРЕ)
}

\section{Аннотация}

В прибрежных водах морей Арктики наиболее распространенными видами фукусовых водорослей являются Fucus vesiculosus, Fucus spiralis, Ascophyllum nodosum. Установлено, что биоактивные соединения (такие как полифенолы, полисахариды, белки, аминокислоты и др.), присутствующие в бурых водорослях, обладают разнообразными биологическими свойствами: антиоксидантными, противовирусными, антибактериальными, антикоагулянтными и др. Извлечение биологически активных веществ из макроводорослей с целью получения продукции с необходимыми свойствами основано на химическом составе сырья, который зависит от условий мест произрастания, а также природе растворителя, метода экстракции и др. В данной работе представлены результаты сравнительного исследования экстрактов из трех видов сем. Fucaceae, собранных на побережье Баренцева моря и моря Ирмингера (Западная Исландия), по содержанию полифенолов. Определена антиоксидантная активность экстрактов по реакции с 2,2-дифенил-1-пикрилгидразил (DPPH). Показано, что содержание полифенолов в экстрактах зависит от района произрастания, в то время как их антиоксидантная активность значимо не отличается, что позволяет предположить присутствие других антиоксидантов в экстрактах.

Ключевые слова: антиоксидантная активность, полифенолы, экстракция, бурые водоросли.

\author{
L.V. Zakharova, E.D. Obluchinskaya
}

Murmansk Marine Biological Institute RAS, Murmansk, Russia

\section{POLYPHENOL AND ANTIOXIDANT ACTIVITY OF FOCUS ALGAE EXTRACTS FROM FAKSAFLOI BAY (IRMINGER SEA) AND ZAVALISHIN BAY (BARENTS SEA)}

\section{Abstract}

In the coastal waters of the Arctic, the most common species of Fucoids are Fucus vesiculosus, Fucus spiralis, and Ascophyllum nodosum. It was reported that bioactive compounds present in brown algae (such as polyphenols, polysaccharides, proteins, amino acids, etc.) have a variety of biological properties: antioxidant, antiviral, antibacterial, anticoagulant, etc. Extraction of biologically active substances from macroalgae in order to obtain products with the necessary properties is based on several factors: the chemical composition of the raw material, which depends on the conditions of the collection sites, as well as the nature of the solvent, the extraction method, etc. This paper presents the results of a comparative study of extracts from 
three Fucaceae family species collected on the coast of the Barents Sea and the Irminger Sea (West Iceland) for polyphenol content. The antioxidant activity of the extracts was also determined by reaction with 2,2-diphenyl-1-picrylhydrazyl (DPPH). It was shown that the content of polyphenols in extracts depends on the places of collection of algae, and their antioxidant activity does not differ significantly, which suggests the presence of other antioxidants in the extracts.

Keywords: antioxidant activity, polyphenols, extraction, brown algae.

Введение. Побережья морей Арктики и Северной Атлантики богаты бурыми водорослями. Из-за высокого содержания полисахаридов, полифенолов, полиненасыщенных жирных кислот, незаменимых аминокислот и витаминов морские водоросли являются хорошим источником здоровой пищи (Phenolic ..., 2015). Известно, что метаболиты водорослей обладают цитостатической, противовирусной, противогрибковой и антибактериальной активностью, которая связана с наличием мощных и нетоксичных природных антиоксидантов (Characteristics ..., 2020). Антиоксидантный эффект связан с полифенолами и, в частности, с флоротаннинами, олигомерами или полимерами флороглюцина. Считается, что они встречаются только в бурых водорослях (Imbs, Zvyagintseva, 2018). Антиоксидантная активность флоротаннинов, экстрагированных из различных видов бурых водорослей, была продемонстрирована in vitro (Relationship ..., 2019; Antioxidant ..., 2020). Некоторые полифенольные соединения, также проявляющие антиоксидантный эффект, такие как катехины, флавонолы и гликозиды флавонолов, были идентифицированы в метанольных экстрактах красных и бурых водорослей (Extraction ..., 2015).

Полифенолы играют разнообразную роль на протяжении всей жизни растения, от его роста и размножения до образования клеточных стенок и пигментации (Imbs, Zvyagintseva, 2018; Characteristics ..., 2020). Содержание полифенолов в водорослях зависит от сезона, температуры воды, интенсивности света и доступности питательных веществ, их концентрация может достигать максимального уровня - до $20 \%$ от сухой массы водорослей (Ткач, Облучинская, 2017; Рыжик, Фисак, 2018; Relationship ..., 2019).

Цель исследований - определение содержания общих полифенолов в экстрактах бурых водорослей трех видов, произрастающих в прибрежных акваториях Баренцева моря и на побережье западной Исландии, и оценка их антиоксидантной активности. Для получения экстрактов из бурых водорослей Fucus vesiculosus L., 1753, Fucus spiralis L., 1753, Ascophyllum nodosum (L.) Le Jolis, 1863 использовали бинарную систему растворителей, состоящую из ацетона и воды. Методика экстракции была усовершенствована ранее для получения экстрактов с высоким выходом полифенолов (Захарова, 2020). Тест на способность улавливания 
радикалов 2,2-дифенил-1-пикрилгидразил (DPPH) применяли для оценки антиоксидантной активности экстрактов.

По мере роста интереса на натуральные продукты с меньшим количеством химических добавок антиоксидантные ингредиенты из растений привлекают большое внимание для использования в качестве консервантов пищевых продуктов или нутрицевтиков. Антиоксиданты могут служить пищевыми консервантами вместо химических добавок (Optimization ..., 2019).

Материал и методы. Объектами являлись образцы бурых водорослей Fusus vesiculosus, Fusus spiralis и Ascophyllum nodosum. Водоросли были собраны во время отлива в летний период 2019 г. в бухте Завалишина (губа Териберская) в Баренцевом море $-69^{\circ} 11.02^{\prime}$ с. ш. $35^{\circ} 14.73^{\prime}$ в. д. и в заливе Факсафлоуи (море Ирмингера) на западном побережье Исландии $64^{\circ} 07.25^{\prime}$ с. ш. $21^{\circ} 55.84^{\prime}$ з. д.

Образцы водорослей были промыты на месте морской водой, талломы очищены от эпифитов, затем высушены в помещении при постоянной температуре $25^{\circ} \mathrm{C}$. Воздушно-сухие талломы водорослей измельчали с помощью блендера (Redmond, Китай).

Экстракцию полифенолов проводили с использованием 70 \%-го водного раствора ацетона. Для наиболее полного извлечения полифенолов была проведена многократная исчерпывающая экстракция по описанной ранее методике (Захарова, 2020).

Содержание общих полифенолов (далее - полифенолов) в экстрактах водорослей определяли спектрофотометрически с использованием реагента Фолина-Чокальтеу согласно методике (Obluchinskaya, Daurtseva, 2020). В качестве стандарта использовали флороглюцин (Sigma-Aldrich, Германия).

Активность образцов по улавливанию свободных радикалов определяли с использованием DPPH (2,2-дифенил-1-пикрилгидразил) в соответствии с методикой (Content ..., 2017; Effect ..., 2020). Антиоксидантную активность (АОА) выражали в процентах ингибирования активности DPPH.

Результаты трех параллельных измерений были обработаны методами описательной статистики с оценкой нормальности распределения. Статистические данные были рассчитаны с использованием STATISTICA (система программного обеспечения для анализа данных; версия 10, StatSoft, Inc., 2011).

Методом однофакторного дисперсионного анализа (ANOVA) проведена оценка влияния места сбора водорослей на концентрацию полифенолов в экстрактах и их АОА (Ивантер, Коросов, 2011).

Результаты и обсуждение. Фенольные соединения - это большая группа веществ с различным составом и структурой как водорастворимых, так и липофильных, поэтому процедуры экстракции также значительно различаются. Известно, что степень экстракции зависит от используемого растворителя и условий экстракции. На экстракцию полифенолов и АОА влияет выбор растворителя (Effect ..., 
2014). Например, считается, что флоротаннины лучше экстрагируются водой, чем водно-этанольными растворами, но не так эффективно, как растворами ацетона (Barton, 1983). Полярность растворителя, а также растворимость соединений существенно влияют на переход полифенолов в экстракт. Особенности экстракции антиоксидантов изучены для наземных растений, однако для бурых водорослей полностью не исследованы. Например, в исследовании (Optimization ..., 2019) для Ascophyllum nodosum оптимальное условие для получения экстракта с наиболее сильной АОА температура экстракции $\left(20^{\circ} \mathrm{C}\right)$ и концентрация этанола $(80 \%)$.

Схемы экстракции растворителем и то, как условия влияют на содержание полифенолов в растворах и их АОА, изучались ранее для некоторых видов красных и бурых водорослей (Content ..., 2017; Relationship ..., 2019). Нагревание экстрактов приводило к увеличению степени экстракции полифенолов, но чаще к снижению их АОА. Используемая в этом исследовании схема экстракции обеспечивает высокий процент выхода полифенолов, а экстракция при пониженной температуре позволяет избежать перехода в раствор балластных веществ и снижения АОА.

В предыдущих исследованиях (Захарова, 2020; Облучинская, Захарова, 2020) было выявлено, что наиболее ценным сырьем для извлечения полифенольных соединений являются бурые водоросли Fucus vesiculosus, произрастающие в бухте Завалишина Баренцева моря, где было отмечено наиболее высокое суммарное содержание полифенолов. Наименьшее суммарное количество полифенолов выявлено в водорослях, произрастающих на западном побережье Исландии (залив Факсафлоуи, море Ирмингера) В данном исследовании проведено сравнение АOА экстрактов из Fucus vesiculosus, а также двух других широко распространенных видов бурых водорослей, собранных в тех же районах.

На рисунке 1 показаны результаты определения содержания полифенолов в экстрактах трех видов фукусов из разных мест обитания, которые сильно различаются.

Содержание полифенолов в экстрактах бурых водорослей Баренцева моря находится в диапазоне 1.8-4.5 мг/мл, что превышает таковое в экстрактах исландских водорослей. Содержание полифенолов в экстрактах Fucus vesiculosus бухты Завалишина в 6.5 раза выше, чем в экстрактах этой водоросли в заливе Факсафлоуи, экстракты Fucus spiralis и Ascophyllum nodosum в 3.5 и 2.5 раза соответственно.

Антиоксидантная активность экстрактов исследуемых водорослей представлена на рис. 2. В соответствии с ранее предложенной гипотезой активность по улавливанию радикалов полифенольных соединений, особенно флоротаннинов, определяется фенольными гидроксильными группами, присоединенными к кольцевой структуре, и обычно согласуется с увеличением содержания общих полифенолов в экстрактах водорослей (Imbs, Zvyagintseva, 2018; Relationship ..., 2019; Caracteristecs ..., 2020). 


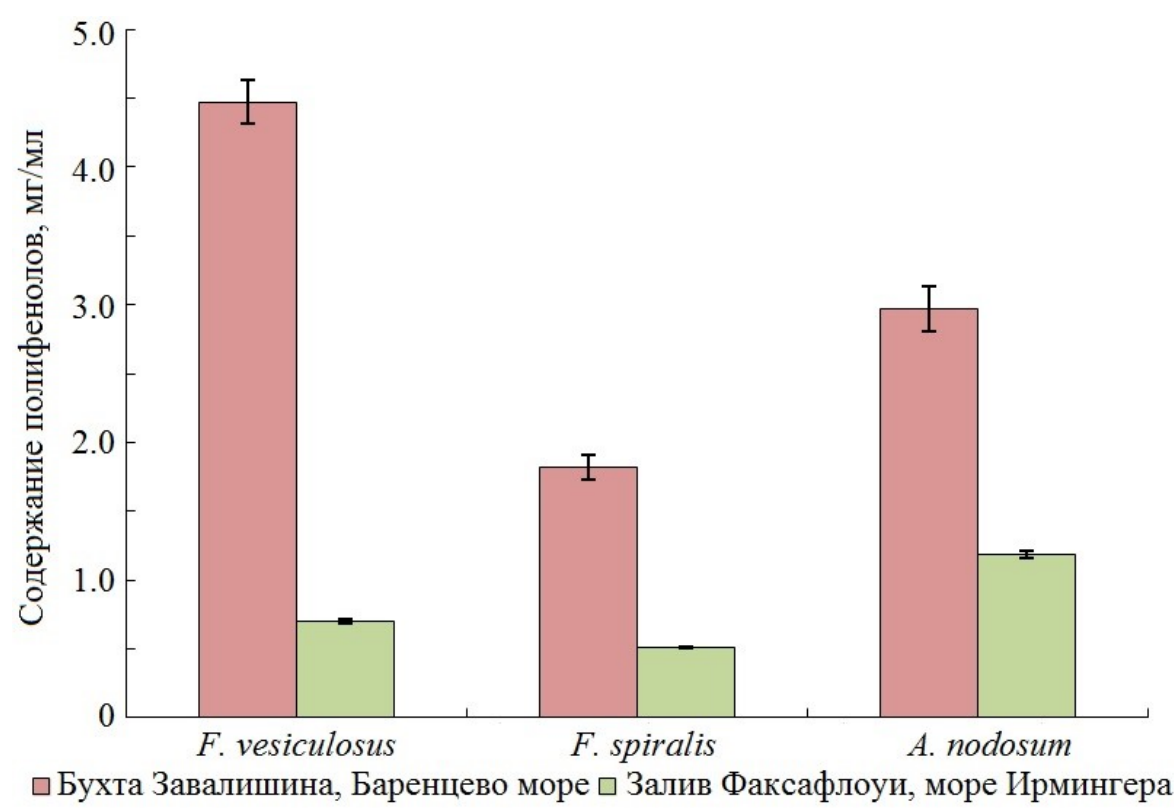

Рис. 1. Содержание общих полифенолов в экстрактах фукусовых водорослей побережья Баренцева моря и западного побережья Исландии

Fig. 1. The total content of polyphenols in the extracts of focus algae of the coast of the Barents Sea and the west coast of Iceland

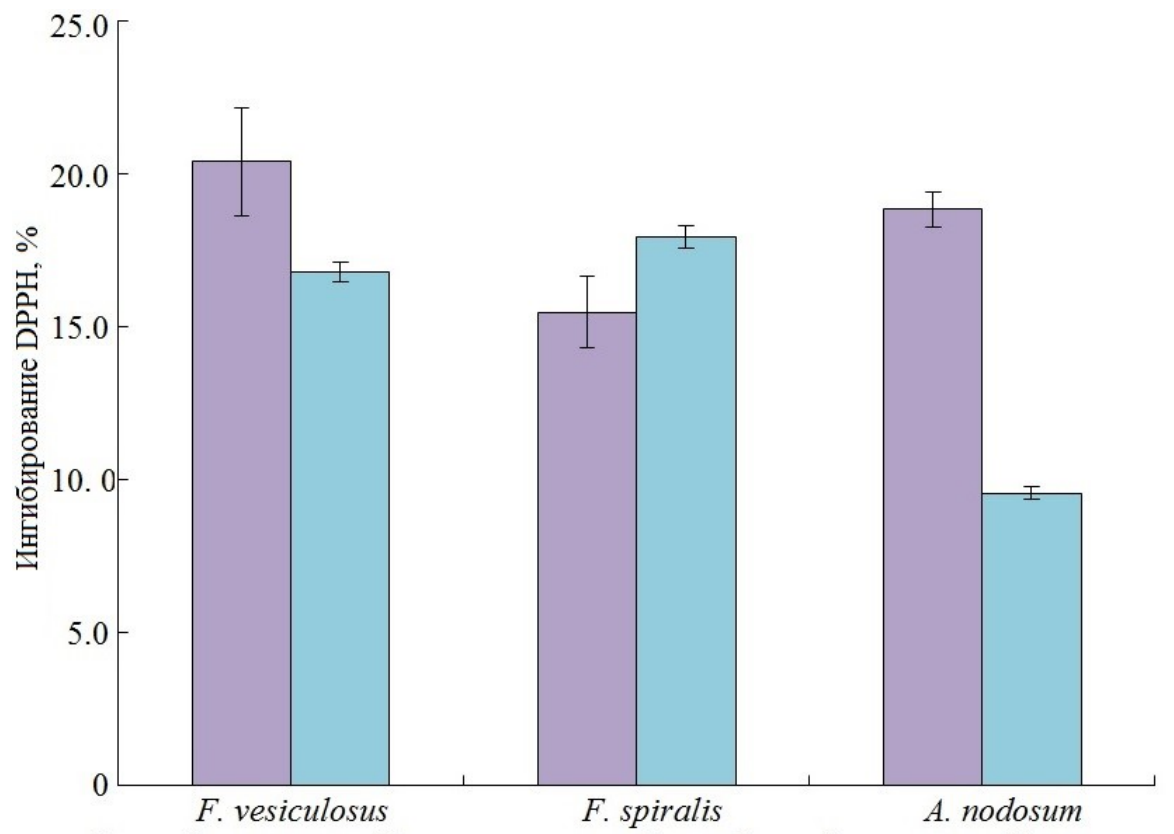

$\square$ Бухта Завалишина, Баренцево море чЗалив Факсафлоуи, море Ирмингера

Рис. 2. Антиоксидантная активность экстрактов фукусовых водорослей побережья Баренцева моря и моря Ирмингера

Fig. 2. AOA of extracts of fucus algae of the coast of the Barents Sea and the Irminger Sea 
Антиоксидантная активность экстрактов трех видов фукусов бухты Завалишина составила 15.5-20.4 \%, для экстрактов водорослей залива Факсафлоуи - 9.6-18 \%. Обнаружено, что, несмотря на низкое содержание полифенолов в экстрактах водорослей залива Факсафлоуи, их АОА сопоставима с таковой экстрактов водорослей бухты Завалишина.

Как правило, содержание полифенолов коррелирует с АОА. В исследованиях (Phenolic ..., 2015; Correlation ..., 2021) обнаружено, что активность по улавливанию радикалов возрастает с увеличением содержания полифенолов. Однако, другие исследования показали, что не всегда существует прямая связь между АОА и содержанием полифенолов (Breton et al., 2011; Characteristecs ..., 2020). Вероятно, структура флоротаннинов и их свойства существенно различаются у разных видов водорослей. Можно также предположить, что у водорослей залива Факсафлоуи присутствуют соединения, обладающие более высокой активностью улавливания радикалов, чем полифенолы. Дальнейшее изучение водорослевых экстрактов с установлением состава, структуры и свойств полифенолов и других биологически активных веществ позволит получить детальную информацию об их влиянии на антиоксидантную активность.

Однофакторный дисперсионный анализ, результаты которого приведены в таблице, показал значимое влияние места произрастания на содержание полифенолов в экстрактах $(p=0.000)$ в отличие от AОА $(p=0.044)$.

\section{Однофакторный дисперсионный анализ влияния мест произрастания водорослей на содержание полифенолов в экстрактах и их антиоксидантную активность \\ One-way analysis of variance of the effect of the algae collection place of algae on the polyphenols content in extracts and their AOA}

\begin{tabular}{l|c|c|c}
\hline \multicolumn{1}{c|}{$\begin{array}{c}\text { Характеристика } \\
\text { экстрактов }\end{array}$} & F-ratio & p-value & $\begin{array}{c}\text { Power } \\
(\alpha=0.04)\end{array}$ \\
\hline Содержание полифенолов & 32.95 & 0.000030 & 0.999482 \\
Антиоксидантная активность & 4.80 & 0.043530 & 0.497310
\end{tabular}

Заключение. В ходе исследований определено содержание полифенолов в экстрактах водорослей трех видов из районов, расположенных в Баренцевом море и море Ирмингера.

Содержание полифенолов в экстрактах бурых водорослей бухты Завалишина (Баренцево море) составило 1.8-4.5 мг/мл, что в 2.5-6.5 раза превышает таковое в экстрактах водорослей залива Факсафлоуи. Антиоксидантная активность экстрактов трех видов фукусов Баренцева моря соответствовала 15.5-20.4\%, для экстрактов водорослей моря Ирмингера - 9.6-18.0\%. 
Однофакторный дисперсионный анализ выявил значимое влияние мест произрастания на содержание полифенолов в экстрактах трех видов фукусовых водорослей, а для АОА не было обнаружено значимых различий. Вероятно, это может быть обусловлено разной структурой и составом флоротаннинов, а также наличием других антиоксидантов в водорослях залива Факсафлоуи с более высокой активностью улавливания радикалов. Дальнейшее изучение состава, структуры и свойств полифенолов разных видов бурых водорослей позволит выявить взаимосвязь с их АОА для решения фундаментальных задач и возможного практического использования.

\section{Литература}

Захарова Л.В. Разработка методики экстракции полифенолов из Fucus vesiculosus северных морей // Тр. Кольского науч. центра РАН. 2020. Т. 5(11). Cep. Океанология. Вып. 8. С. 77-81. DOI: 10.37614/2307-5252.2020.11.5.008

Ивантер Э.В., Коросов А. Введение в количественную биологию: Учеб. пособие. Петрозаводск: Изд-во Петр. гос. ун-та, 2011. 302 с.

Облучинская Е.Д., Захарова Л.В. Сравнительное исследование полифенолов бурых водорослей морей Арктики и Северной Атлантики // Химия растительного сырья. 2020. № 4. С. 129-137. URL: https://doi.org/10.14258/jcprm.2020047755

Рыжик И.В., Фисак Е.М. Годовая динамика содержания растворимых флоротаннинов в клетках Fucus vesiculosus L. и возможное их участие в процессах репарации тканей // Вопросы современной альгологии. 2018. № 1(16). С. 4.

Ткач А.В., Облучинская Е.Д. Стерины и полифенолы фукоидов Мурманского побережья Баренцева моря // Вестн. Мурм. гос. техн. ун-та. 2017. Т. 20, № 2. C. 326-335.

Antioxidant activity of extracts from marine macroalgae, wild-collected and cultivated, in an integrated multi-trophic aquaculture system / J.Á.-G.F. Vega, L. Güenaga, F.L. Figueroa, J.L. Gómez-Pinchetti // Aquaculture. 2020. Vol. 522. P. 1-10.

Barton A.F. Handbook of solubility parameters and other cohesion parameters. Coimbra, Portugal: CRC Press. 1983. 594 p.

Breton F., Cérantola S., Gall E.A. Distribution and radical scavenging activity of phenols in Ascophyllum nodosum (Phaeophyceae) // J. Exp. Mar. Biol. Ecol. 2011. Vol. 399. P. 167-172. DOI: 10.1016/j.jembe.2011.01.002

Characteristics of polyphenolic content in brown algae of the Pacific coast of Russia / N.M. Aminina, E.P. Karaulova, T.I. Vishnevskava et al. // Molecules. 2020. Vol. 25, № 17. 3909. URL: https://doi.org/10.3390/molecules 25173909

Content of polyphenols and antioxidant activity of extracts from certain species of seaweeds / N.M. Aminina, T.I. Vishnevskaya, E.P. Karaulova, E.V. Yakush // Izv. TINRO. 2017. Vol. 189. P. 184-191. URL: https://doi.org/10.26428/1606-9919-2017189-184-191

Correlation of total polyphenolic content with antioxidant activity of hydromethanolic extract and their fractions of the Salvia officinalis leaves from different regions of Morocco / Z. Khiya, Y. Oualcadi, A. Gamar et al.// J. Chemistry. 2021. Vol. 2021, P. 1-10. URL: https://doi.org/10.1155/2021/8585313 
Effect of extraction solvent on total phenol content, total flavonoid content, and antioxidant activity of Limnophila aromatica / Q.D. Do, A.E. Angkawijaya, P.L. Tran-Nguyen et al. // J. Food and Drug Analysis. 2014. Vol. 22. P. 296-302. URL: https://doi.org/10.1016/j.jfda.2013.11.001

Effect of drying methods on bioactive compounds, nutritional, antioxidant, and antidiabetic potential of brown alga Durvillaea antarctica / E. Uribe, C.M. PardoOrellana, A. Vega-Gálvez et al. // Drying Technology. 2020. Vol. 38. P. 1915-1928. DOI: $10.1080 / 07373937.2019 .1679830$

Extraction and purification of phlorotannins from brown algae / E.A. Gall, F. Lelchat, M. Hupel et al. // Methods Mol. Biol. 2015. Vol. 1308. P. 131-143.

Imbs T.I., Zvyagintseva T.N. Phlorotannins are polyphenolic metabolites of brown algae // Russ. J. Mar. Biol. 2018. Vol. 44. P. 263-273.

Optimization of antioxidant extraction from edible brown algae Ascophyllum nodosum using response surface methodology / X. Liu, G. Luo, L. Wang, W. Yuan // Food and Bioproducts Processing. 2019. Vol. 114. P. 205-215. URL: https://doi.org/10.1016/j.fbp.2019.01.003

Phenolic content and antioxidant capacity in algal food products / L. Machu, L. Misurcova, J. Vavra Ambrozova et al. // Molecules. 2015. Vol. 20. P. 1118-1133. URL: https://doi.org/10.3390/molecules20011118

Relationship between radical scavenging activity and polymolecular properties of brown algae polyphenols / K. Bogolitsyn, A. Druzhinina, P. Kaplitsin et al. // Chem. Pap. 2019. Vol. 73. P. 2377-2385.

DOI: $10.37614 / 2307-5252.2021 \cdot 3 \cdot 9.010$

УДК 551.46.065

Т.М. Максимовская, Г.В. Ильин

Мурманский морской биологический институт РАН, г. Мурманск, Россия

\section{ГИДРОЛОГИЧЕСКИЕ ИССЛЕДОВАНИЯ В СЕВЕРО-ВОСТОЧНОЙ ЧАСТИ БАРЕНЦЕВА МОРЯ В 2019 И 2020 гг.}

\section{Аннотация}

В статье представлены результаты гидрологических исследований северовосточной части Баренцева моря. Наблюдения выполнены в комплексных океанографических экспедициях НИС “Дальние Зеленцы” ММБИ РАН в октябреноябре 2019 и 2020 гг. Проведен анализ серии гидрологических разрезов, дающих подробное представление о структуре вод и течений изучаемого района. В структуре вод выделено два потока атлантических вод. Потоки направлены противоположно друг другу и расположены в различных глубинных слоях. Выходящий из Баренцева моря атлантический поток идентифицируется как ветвь теплого Новоземельского течения. В начале зимнего периода течение распространяется в слое от поверхности до 50-75 м. Втекающие в море атлантические воды идентифицируются как ветвь глубинного течения желоба Святой Анны. Они поступают из Полярного бассейна и проходят в Баренцево море с востока на запад до $62-60^{\circ}$ в. д. 
Ключевые слова: гидрологические условия, водные массы, Баренцево море, атлантические воды.

T.M. Maksimovskaya, G.V. Ilyin

Murmansk Marine Biological Institute RAS, Murmansk, Russia

HYDROLOGICAL STUDIES IN THE NORTH-EASTERN PART
OF THE BARENTS SEA IN 2019 AND 2020

Abstract

The article presents the results of hydrological studies of the north-eastern part of the Barents Sea. The observations were made in the oceanographic expeditions R/W "Dalnie Zelentsy" of the MMBI RAS in October-November 2019 and 2020. The analysis of a series of hydrological sections is carried out, which details the vision of the structure of the waters and currents of the studied area. In the water structure, two streams of Atlantic waters are distinguished. The flows are directed opposite to each other and are located in different deep layers. The Atlantic stream emerging from the Barents Sea is identified as a branch of the warm New Earth current. At the beginning of the winter, the current spreads in a layer from the surface to $50-75 \mathrm{~m}$. The Atlantic waters flowing into the Barents Sea are identified as a branch of the deep current of the St. Anna trench. They come from the Polar Basin and pass into the sea from east to west up to $62-60^{\circ} \mathrm{E}$.

Keywords: hydrological conditions, water masses, Barents Sea, Atlantic waters.

Введение. В работе рассматривается специфический район северовосточной части Баренцева моря - пролив на границе Баренцева и Карского морей архипелагами Новая Земля и Земля Франца-Иосифа. Район расположен в широтной зоне между 77 и $80^{\circ}$ с. ш. и в некоторых изданиях именуется проливом Макарова (Гидрометеорология..., 1990). Через данный пролив происходит водообмен Баренцева моря с Карским морем и глубоководной частью Северного Ледовитого океана Полярным бассейном. Гидрологический режим района отражает особенности этого водообмена и формируется соответственно под влиянием вод Полярного бассейна и Карского моря.

Для этого арктического пояса характерны нулевые либо отрицательные значения температуры воздуха в течение года и наличие облачности в 8-9 баллов, которая уменьшает поступление прямой солнечной радиации на 60-80 \% по сравнению с безоблачным небом. Большую роль в формировании климата играют поступление в высокие широты теплых атлантических вод и циркуляция атмосферы. Атмосферная циркуляция помимо влияния прямого притока тепла в большой степени определяет направленность холодных и теплых течений, а также степень покрытия льдом морской поверхности. В связи с этим здесь наблюдается более теплый климат в сравнении с другими арктическими морями (Гидрометеорология .., 1990). Приток 
атлантического тепла в северо-восточный сектор моря с течениями происходит, как правило, в придонном и промежуточном слоях водной массы (Midttun, 1985; Loeng et al., 1997; Трофимов и др., 2008; Lien, Alexander, 2013; Воды ..., 2016).

Цель данной работы - изучение структуры вод северо-восточного района моря, роли потоков атлантических вод в водообмене прилегающих акваторий в условиях изменяющегося климата

Материал и методы. В работе использовались данные исследований ММБИ, полученные в экспедиции НИС “Дальние Зеленцы” с 30 октября по 4 ноября 2019 г. и 6-10 октября 2020 г. (рис. 1). Проведены измерения температуры и солености при вертикальном профилировании водной толщи на гидрологических станциях. Для этого использовался СТД-профилограф SBE 19plus V2 SeaCAT (США). Параллельно на этих же станциях измерялись метеорологические параметры с помощью судовой метеостанции.
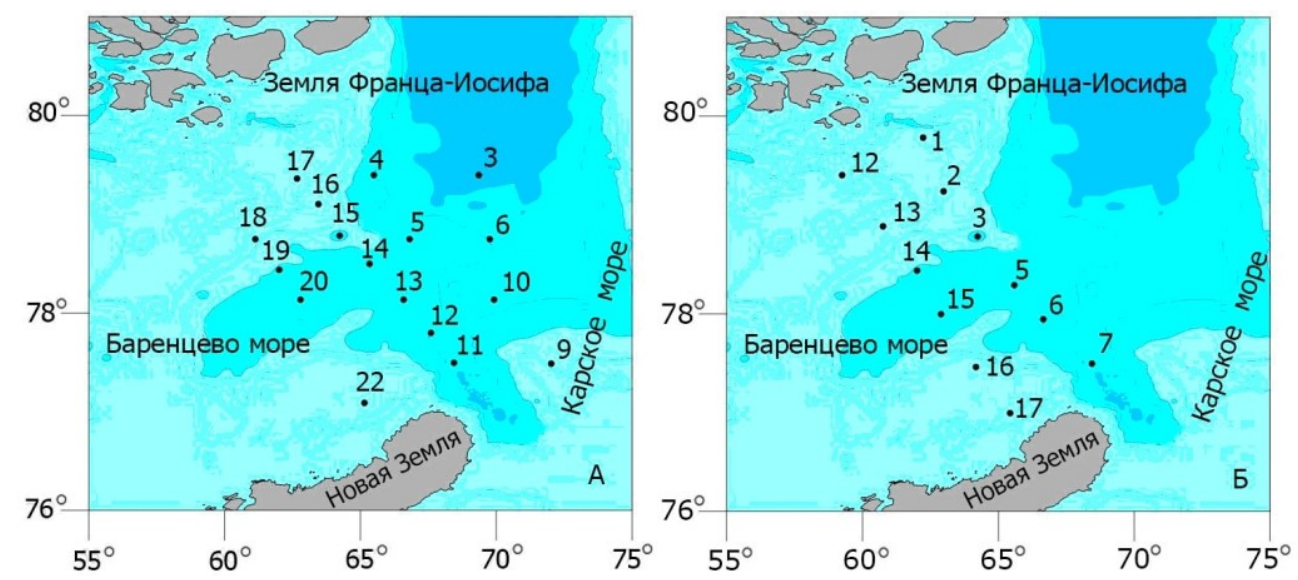

Рис. 1. Схема расположения океанографических станций на акватории северо-восточной части Баренцева моря в 2019 (А) и 2020 гг. (Б)

Fig. 1. The position of oceanographic stations in the north-eastern part of the Barents Sea in 2019 (A) and 2020 (Б)

Результаты и обсуждение. Атмосферные процессы в исследуемом районе формируются под воздействием проникающих на северо-восток атлантических воздушных масс, которые вызывает образование положительных аномалий температуры воздуха зимой на северной оконечности Новой Земли (Гидрометеорология ..., 1990). Величины наблюдаемых в экспедициях показателей состояния приводного слоя атмосферы - температуры и скорости ветра, характеризуются высокой кратковременной изменчивостью на фоне растущего барического поля. Очевидно, что в барических полях в 2019 и 2020 гг. отображены периферийные части циклонов, проходящих на северо-востоке моря в стадии заполнения возникших барических минимумов. Изменения 
температуры воздуха сопряжены с таковыми скорости ветра в суточной и многосуточной динамике, однако эти изменения происходят в противофазе. Видимой короткопериодной взаимосвязи температуры воздуха с атмосферным давлением не прослеживается.

Ветровой дрейф поверхностного слоя воды вызвал подъем к поверхности заглубленного потока атлантических вод Новоземельского течения. Тем самым температура поверхностной воды на прилегающей к Новой Земле акватории моря была увеличена до $1.1{ }^{\circ} \mathrm{C}$. Общий фон температуры воды характеризовался закономерным снижением по направлению к Земле Франца-Иосифа до $-1.5{ }^{\circ} \mathrm{C}$ и образованием фронтального раздела между атлантическими и полярными водами на всей акватории пролива. Распределение солености (от 33.99 до $34.92 \mathrm{psu}$ ) согласуется с распределением температуры воды. В новоземельских водах Карского моря соленость оказывается сниженной до 31 psu. Сложная вертикальная термохалинная структура вод прослеживается на серии разрезов через исследуемую область пролива (рисунки 2, 3).

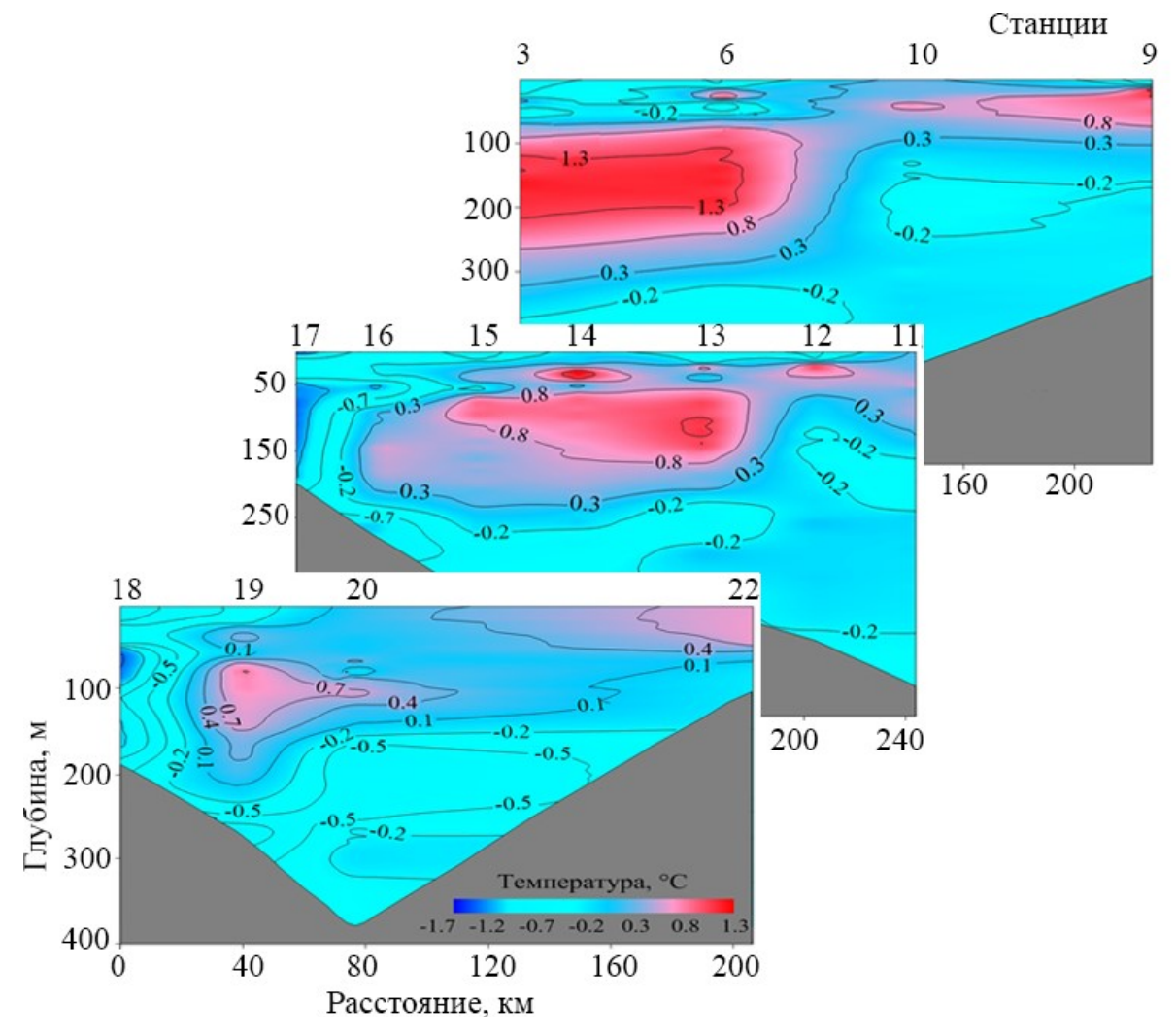

Рис. 2. Профили термической структуры вод в проливе северо-восточной части Баренцева моря, ноябрь 2019 г.

Fig. 2. Profiles of the thermal structure of waters in the strait of the northeastern part of the Barents Sea, November 2019 


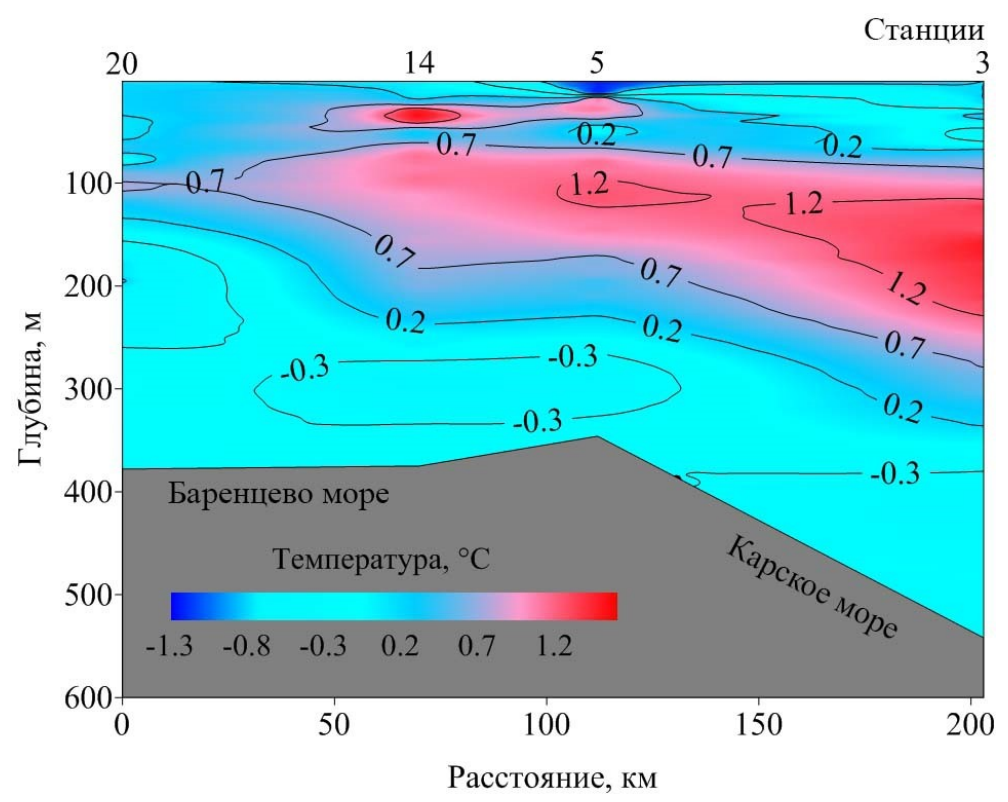

Рис. 3. Профиль термической структуры вод вдоль пролива между Землей Франца-Иосифа и Новой Землей, ноябрь 2019 г.

Fig. 3. Profile of the thermal structure of the waters along the strait between the Franz Josef Land and Novaya Zemlya, November 2019

Верхний 50-метровый слой воды имеет ячеистую структуру. При слабо развитом фронтальном разделе такая структура сопряжена с ветровым воздействием и имеет короткопериодную изменчивость. Ниже этой зоны главными структурообразующими элементами являются потоки атлантических вод, поступающие в пролив с двух направлений.

Один из потоков трансформированных атлантических вод - ветвь Новоземельского течения, проходит вдоль склона Новоземельского шельфа в слое от 25 до 75 м и выходит в Карское море. Температура воды в ядре потока составляет около $1{ }^{\circ} \mathrm{C}$, а соленость - примерно $34.6 \mathrm{psu}$. Распространение атлантических вод в верхних слоях определяет повышение температуры вод зимой до положительных значений $-0.3{ }^{\circ} \mathrm{C}$ на фоне окружающей полярной воды с температурой $-1{ }^{\circ} \mathrm{C}$.

Другой поток вод атлантического происхождения наблюдается в более глубоких слоях - от 100 до 200 м (рис. 3). Поток проходит в Баренцевом море по отрогам желобов, относящихся к понижению Святой Анны, по которому происходит обмен Полярного бассейна с Карским и Баренцевым морями. На вертикальных профилях можно наблюдать, что поток теплых вод ослабевает в западном направлении. Одновременно в ядре потока снижается температура воды с 1.3 до $0.8{ }^{\circ} \mathrm{C}$. Соленость воды меняется мало и варьирует около $34.8 \mathrm{psu}$, что близко к солености зимних полярных вод. 
Такой заглубленный поток вдоль $78^{\circ}$ с. ш. был выявлен и в летнеосенний период (в сентябре-октябре 1997 г.) экспедицией Института океанологии им. П.П. Ширшова РАН на НИС “Академик Сергей Вавилов". Ядро потока было заглублено до 150 м, а воды имели практически те же термохалинные характеристики. Их температура и соленость составляли, соответственно, $1.5^{\circ} \mathrm{C}$ и $34.83 \mathrm{psu}$ (Лебедев, 1999).

Как уже отмечалось, ветровое поле оказывает определяющее влияние на вертикальную и горизонтальную структуру вод верхнего 50-метрового слоя. Подходящие близко к верхнему слою потоки атлантических вод под воздействием ветра вовлечены в формирование структуры вод перемешанного слоя в виде разновеликих линз на акватории пролива. Отепляющее влияние этих линз на фоне отрицательных температур полярных вод замедляет выхолаживание и становление ледяного покрова в начальный период зимы.

Заключение. Таким образом, исследование гидрологического режима северо-восточной части Баренцева моря обнаруживает следующее характерные черты. Термохалинная структура этого морского района формируется в результате взаимодействия двух основных водных масс полярной и атлантической при воздействии ветрового поля. Трансформированные атлантические воды поступают сюда двумя устойчивыми разнонаправленными потоками в глубинных слоях. Заглубление потоков может варьировать при изменениях синоптических условий, в первую очередь ветровых полей.

Выходящая из Баренцева моря ветвь Новоземельского течения проходит вдоль склона и оказывает отепляющее влияние на шельф Новой Земли и прилегающую акваторию Карского моря. Поток атлантических вод из Полярного бассейна проходит на запад в Баренцево море до 62$60^{\circ}$ в. д. и рассеивается по мере выклинивания направляющих течение желобов и выравнивании донного рельефа в проливе.

Термохалинная структура вод верхнего 50-метрового слоя в зимний период весьма мозаична, ее изменчивость зависит от ветровой нагрузки. Наблюдавшаяся во время экспедиционных исследований структура была сформирована в результате длительного (в течение 6 сут.) воздействия ветра со средней скоростью $12.5 \mathrm{~m} / \mathrm{c}$. Устойчивое направление ветра формируется подповерхностные линзы теплой и соленой воды, которых замедляют становление ледяного покрова в проливе и определяют благоприятные условия судоходства в зимних условиях.

Работа выполнена в рамках государственного задания.

\section{Литература}

Boдbl Баренцева моря: структура, циркуляция, изменчивость / В.К. Ожигин, В.А. Ившин, А.Г. Трофимов и др. Мурманск: Изд. ПИНРО, 2016. 260 с. 
Гидрометеорология и гидрохимия морей СССР (проект “Моря СССР”). Т. 1. Баренцево море. Вып. 1. Гидрометеорологические условия. Л.: Гидрометеоиздат, 1990. $280 \mathrm{c}$.

Лебедев К.В. Атлантические воды в северо-восточной части Баренцева моря // Океанология. 1999. Т. 39, № 6. С. 832-842.

Трофимов А.Г., Титов О.В., Педченко А.П. Изучение термохалинной структуры и циркуляции вод на северо-восточной границе Баренцева моря в 2007-2008 гг. // Вопросы промысловой океанологии. 2008. Вып. 5, № 2. С. 80-91.

Loeng H., Ozhigin V., Aadlandsvik B. Water fluxes through the Barents Sea // J. Mar. Sci. ICES. 1997. Vol. 54. P. 310-317.

Midttun L. Formation of dense bottom water in the Barents Sea // Deep Sea Research. 1985. Vol. 32(10). P. 1233-1241.

Lien V.S., Alexander G.T. Formation of Barents Sea Branch Water in the north-eastern Barents Sea // Polar Research. 2013. Vol. 32. URL: http://dx.doi.org/10.3402/polar.v32i0.18905

DOI: $10.37614 / 2307-5252.2021 \cdot 3.9 .011$

УДК $574.58(268.45)$

\section{С.В. Малавенда}

Мурманский морской биологический институт РАН, г. Мурманск, Россия

\section{ВОДОРОСЛИ ГУБЫ ВЕРЕСОВАЯ КОЛЬСКОГО ЗАЛИВА (БАРЕНЦЕВО МОРЕ)}

\section{Аннотация}

Представлен видовой состав макроводорослей и перифитона губы Вересовая Кольского залива. Отмечено 17 видов водорослей: 3 - Charophyta, 13 Chlorophyta, 1 - Rhodophyta. Наибольшее число видов зафиксировано в начале осени, наименьшее - зимой. Макроводоросли образуют покров только на левом берегу, скопления харовых водорослей отмечены на обоих берегах. Наибольшая частота встречаемости характерна для Rhizoclonium riparium и Cladophora rivularis. Водоросли родов Nitella, Ulothrix, Zygnema и Spirogyra преобладают по биомасcе.

Ключевые слова: Chlorophyta, Zygnema, эстуарий, фитобентос, перифитон, губа Вересовая, Кольский залив.

\section{S.V. Malavenda}

Murmansk Marine Boilogical Institute RAS, Murmansk, Russia

\section{ALGAE OF THE VERESOVAJA BAY OF THE KOLA BAY (BARENTS SEA)}

\section{Abstract}

The species composition of macroalgae in the benthos and periphyton of the Veresovaya Bay is presented. 17 species were noted. The largest number of species is recorded in early autumn, the smallest-in winter. Macroalgae form a cover only on the left bank, 
accumulations of Chara algae are noted on both banks. The highest frequency of occurrence is characteristic of Rhizoclonium riparium and Cladophora rivularis. Algae of the genera Nitella, Ulothrix, Zignema and Spirogira predominate in mass.

Keywords: Chlorophyta, Zygnema, phytobentos, periphyton, Veresovaja Bay, Kola Bay.

В целом для Кольского залива Баренцева моря описана флора водорослей-макрофитов, составлены карты распределения биомассы и сообществ (Завалко, Шошина, 2008; Малавенда, 2018). Из 94 видов водорослей-макрофитов 18 относится к зеленым, 33 - к красным и 43 к бурым. Что касается их распределения по заливу, то в северном колене отмечено 17 представителей зеленых, 31 - бурых и 39 - красных, a, соответственно, в среднем и южном коленах - 15, 22, 37 и 8, 12, 4 вида (Малавенда, 2018). Однако для губы Вересовая, расположенной в Кольском заливе, альгологические сведения отсутствуют. Следует отметить, что в губу впадает р. Тулома, образующая обширный эстуарий.

Цель работы - описание видового состава и сезонной динамики водорослей литорали и верхней сублиторали губы Вересовая.

Материал и методы. Исследование макроводорослей проводили с июня 2018 г. по декабрь 2019 г. включительно. Оценивали распределение, доминантные виды и проективное покрытие. На наиболее типичных участках растительного покрова отбирали количественные пробы водорослей. Сбор водорослей осуществляли с валунов и высшей растительности по методам сбора пресноводного перифитона (Руководство ..., 1983), с грунта - как морской фитобентос (Руководство ..., 1992). В первом случае отбирали по несколько экземпляров доминирующего вида растений или делали соскобы с валунов. Во втором случае использовали рамку $10 \times 10 \mathrm{~cm}$. Собирали все водоросли, основание которых (ризоиды или диск) оказывались внутри рамки. На станции отбирали по три пробы, каждую пробу фиксировали. Где водоросли не формировали плотного покрова и были не видны невооруженным глазом, в пробу собирали верхний 0.5-сантиметровый слой грунта, который затем исследовали под микроскопом. Дополнительно отбирали образцы для видовой идентификации водорослей.

Все пробы фиксировали 4 \%-м раствором формалина в пресной воде в течение 2-4 ч после сбора. Для образцов водорослей была выполнена гербаризация.

В лабораторных условиях проводили видовую идентификацию водорослей, определяли их биомассу с точностью до 0.01 г. Для видового определения использовали определители для пресноводных водорослей, статьи и комментарии международной обновляемой базы данных по водорослям AlgaeBase (http://www.algaebase.org), ключи и таблицы из различных полевых определителей и статей по флорам рек (Голлербах и др., 1953; Дедусенко-Щеголева и др., 1959; Паламарь-Мордвинцева, 1982; Голлербах, Красавина, 1983; Кольский ..., 1997; Комулайнен, 2005). 
Результаты и обсуждение. В губе Вересовая в 2018-2019 гг. всего было выявлено 18 видов макроводорослей, из них 3 - харовые водоросли, 13 - представители зеленых, 1 - красных (таблица).

Видовой состав макроводорослей в губе Вересовая Species composition of macroalgae in Veresovaya Bay

\begin{tabular}{|c|c|c|c|c|}
\hline Таксон & Весна & Лето & Осень & Зима \\
\hline \multicolumn{5}{|l|}{ Отдел Charophyta } \\
\hline Chara vulgaris & - & - & + & - \\
\hline Nitella aff. ораса & + & + & + & + \\
\hline Spirogyra sp. & - & - & + & - \\
\hline Отдел Chlorophyta & & & & \\
\hline Blidingia minima & - & - & + & - \\
\hline Chaetomorpha tortuosa & - & + & + & + \\
\hline Cladophora fracta & + & + & - & - \\
\hline Cladophora rivularis & - & + & - & + \\
\hline Derbesia aff. tenuissima & - & - & + & - \\
\hline Rhizoclonium riparium & - & + & - & + \\
\hline Stigeoclonium sp. & - & - & + & - \\
\hline Stichococcus bacillaris & - & + & - & - \\
\hline Ulothrix tenuissima & - & + & - & - \\
\hline Ulothrix zonata & - & + & + & - \\
\hline Urospora aff. penicilliformis & - & + & - & - \\
\hline $\begin{array}{l}\text { Zygnema sp. } \\
\text { Отдел Rhodophyta }\end{array}$ & - & - & + & + \\
\hline Audouinella sp. & - & + & - & - \\
\hline & 2 & 10 & 9 & 5 \\
\hline
\end{tabular}

Для флоры Кольского залива 3 вида Charophyta и 8 видов Chlorophyta paнее не указывались, поэтому ниже приведем краткую характеристику их распределения.

Отдел Charophyta

Chara vulgaris Linnaeus, 1753 - обнаружена только среди рдестов на правом берегу губы в верхней сублиторали. Пресноводный вид.

Nitella sp. (Nitella C. Agardh, 1824) - вероятно, Nitella opaca (C. Agardh ex Bruzelius) C. Agardh, 1824. Водоросль распространена в губе Вересовая повсеместно в течение всего периода исследований в виде отдельных талломов или скоплений биомассой до 110 г/ $\mathrm{M}^{2}$. Произрастает среди рдестов на границе литорали и сублиторали. Пресноводный вид.

Spirogyra sp. (Spirogyra Link, 1820, nom. cons.) - обнаружена на более крутом левом берегу на галечно-скалистом грунте в конце

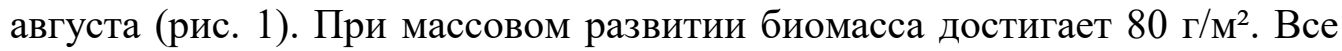
представители рода относятся пресноводным видам.

\section{Отдел Chlorophyta}

Класс Cladophoraceae

Cladophora fracta (O.F. Müller ex Vahl) Kützing, 1843 - отмечена летом на нижней границе литорали. Морской вид, выдерживает распреснение. 
Cladophora rivularis (Linnaeus) Kuntze, 1891 - зарегистрирована главным образом на рдестах летом и осенью отдельными маленькими талломами. Пресноводный вид

Chaetomorpha tortuosa (Dillwyn) Kleen, 1874 - обнаружена на валунах берегов губы в конце августа. Вид формировал плотный слой биомассой до 600 г/м². Вид морской, но выдерживает распреснение.

Stigeoclonium sp. Kützing, 1843, nom. cons. - единично отмечен в составе обрастаний рдестов. Представители рода являются пресноводными. Класс Stichococcaceae

Stichococcus bacillaris Nägeli, 1849 - единичная находка весной на песчаном грунте на литорали правого берега губы. Вид широко распространен в морских и пресных водах.

Класc Ulvophyceae

Ulothrix tenuissima Kützing, 1833 - отмечен весной на левом берегу на галечно-песчаном грунте (рис. 1), где наряду с другими видами формировал плотный растительный покров, биомасса которого достигала 300 г/м². Вид распространен в морских и пресных водах.

Ulothrix zonata (F. Weber \& Mohr) Kützing, 1833 - единичные талломы обнаружены летом на рдестах (рисунки 1, 2). Пресноводный вид.

Класс Zygnemataceae

Zygnema sp. C. Agardh, 1817 - единичные талломы обнаружены летом и осенью на рдестах (рис. 1). Представители рода произрастают в пресных водах.

Из числа выявленных таксонов два вида являются морскими, но мы сомневаемся в правильности определения, хотя морфология типичная:

Derbesia aff. tenuissima (Moris \& De Notaris) P. Crouan \& H. Crouan, 1867 - несколько талломов отмечено на рдестах правого берега губы;

Urospora aff. penicilliformis (Roth) Areschoug, 1866 - летом часто фиксировали отдельными нитями среди Ulothrix sp.

К видам, распространенным и в губе Вересовая и в Кольском заливе, относятся следующие представители.

Blidingia minima (Nägeli ex Kützing) Kylin, 1947 - обнаружена на валунном грунте левого берега в конце августа, биомасса локального поселения - 130-264 г/м². Морской вид, но способен выдерживать распреснение.

Rhizoclonium riparium (Roth) Harvey, 1849 - отмечен летом и зимой в составе бентоса и перифитона в небольших количествах (рис. 1). Вид повсеместно распространен в Кольском заливе. Произрастает в морях и пресных водоемах.

Audouinella sp. - талломы зарегистрированы единожды летом на песчаном грунте.

Наибольшая биомасса среди всех макроводорослей свойственна харовым водорослям, главным образом Nitella sp. Локальная вспышка численности наблюдалась у Spirogyra sp. В целом биомасса водорослей в губе Вересовая невелика, доминирующие виды сменяют друг друга по сезонам. 

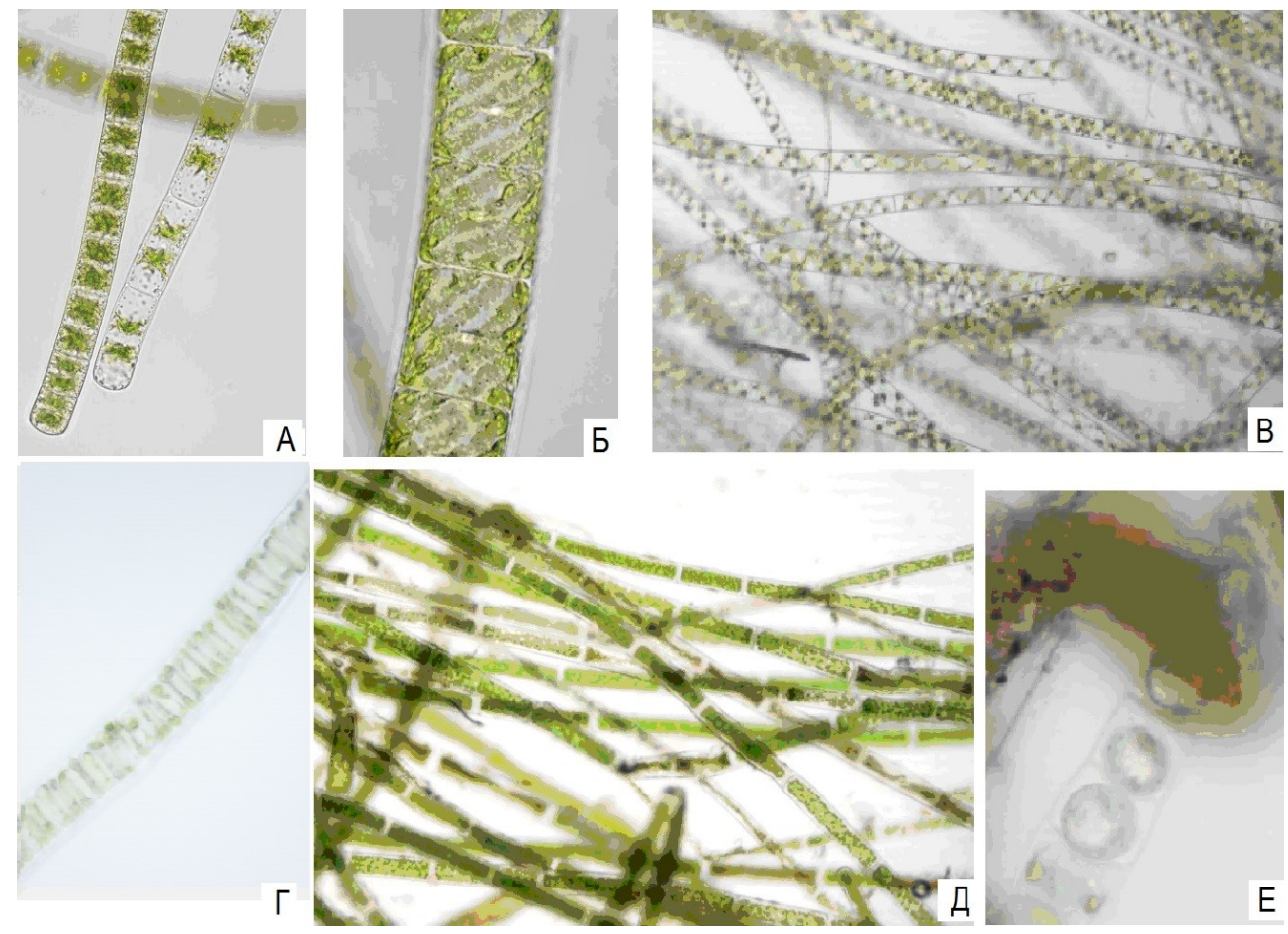

Рис. 1. Микрофотографии водорослей из губы Вересовая:

A - Zygnema sp.; Б, В - Spirogyra sp.; Г - Ulothrix tenuissima; Д - Rhizoclonium riparium; E - Ulothrix zonata

Fig. 1. Microphotographs of some algae from the Veresovaya Bay:

A - Zygnema sp.; Б, В - Spirogyra sp.; Г - Ulothrix tenuissima; Д - Rhizoclonium riparium; E - Ulothrix zonata
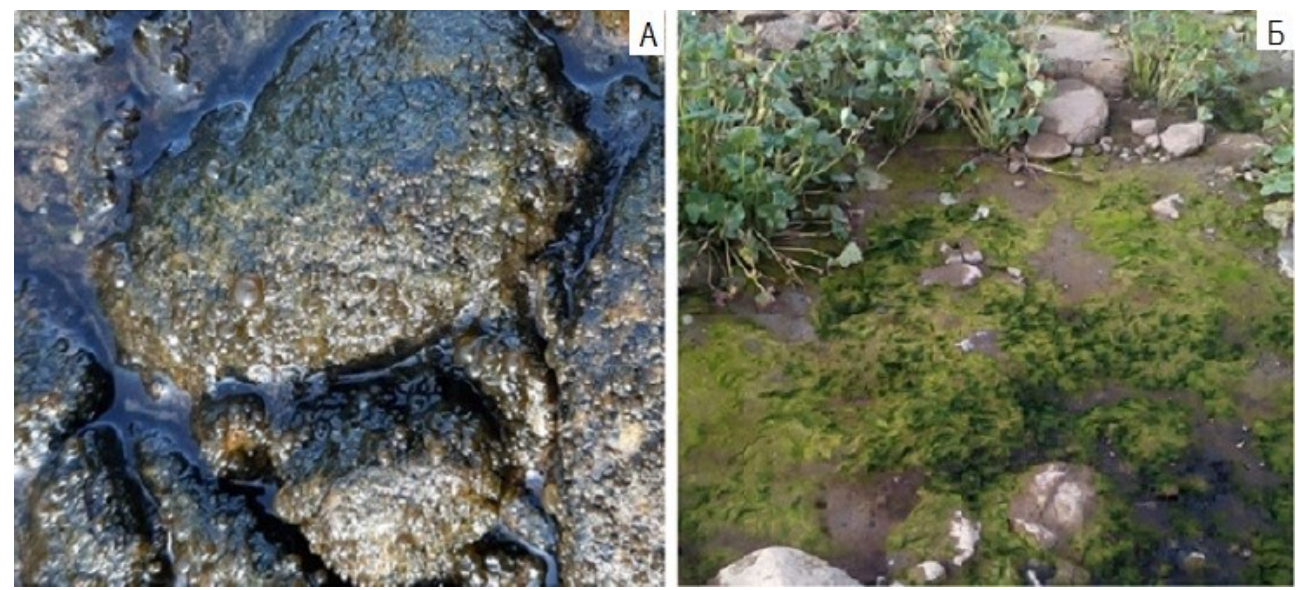

Рис. 2. Типичный внешний вид скоплений водорослей:

А - обрастание валунов Ulothrix zonata, июнь; Б - массовое развитие зеленых нитчатых водорослей на песчаном грунте с валунами и скальным основанием, август

Fig. 2. Typical exterior of algae fouling:

A - Uothrix zonata covers on boulders, June; Б - green filamentous algae in mass cover on sandy soil with boulders and rocks, August 
Полученные данные по видовому составу макроводорослей из губы Вересовая характеризуют ее как эстуарный водоем. Примерно одна половина отмеченных здесь видов произрастает в пресных и морских водах, а вторая - в пресных. По числу видов существенно преобладают представители отделов Chlorophyta и Charophyta, что свойственно пресным водоемам. Отсутствуют Phaeophycea, среди которых нет пресноводных видов. Таким образом, хотя описанные альгоценозы являются пресноводными, что не исключает их связь с морской флорой.

Распределение водорослей по литорали носит сезонный характер. Весной водоросли встречаются повсеместно, но биомасса их невелика -

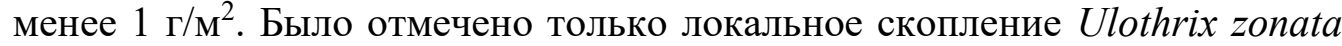

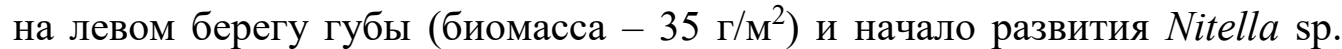
в верхней сублиторали правого берега. Летом водоросли массово развиваются на левом берегу. Они формируют на этом участке большую биомассу (до 1020.0 г/м²), преобладает Ulothrix zonata. Осенью тонкий налет на камнях и грунте формируют зеленые нитчатые водоросли, отмечаются единичные талломы Nitella sp. На грунте зарегистрированы также отдельные нити различных зеленых водорослей, суммарная

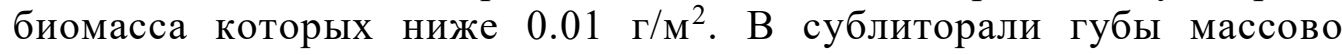
развиваются харовые водоросли - Nitella sp. и Chara sp., которые формируют покров наряду с высшей растительностью. Многочисленна ульвовая водоросль Blidingia minima, в местах скопления которой биомасса достигает 200 г/м². На отдельных участках дна левого берега произрастает Spirogyra sp., которая формирует тонкий покров на грунте (биомасса $-80 \Gamma / \mathrm{M}^{2}$ ). В начале зимы водоросли не формируют покров на большей части литорали губы. Наиболее распространенными являются зеленые водоросли Rhizoclonium sp., также на участке верхней сублиторали заметную биомассу формируют харовые водоросли.

Распределение водорослей на литорали губы Вересовая существенно отличается от других районов Кольского залива преобладанием харовых. Сезонность развития зеленых водорослей встречается на подвижных грунтах в заливе (Малавенда и др., 2017).

Заключение. Впервые представлен видовой состав водорослей наиболее пресной части Кольского залива - губы Вересовая. Уникальное сочетание пресных и морских вод, а также правильных полусуточных колебаний уровня воды обусловили формирование широкой литорали, где сформировались растительные сообщества с массово развитыми сосудистыми растениями и водорослями. Выявлено 3 вида харовых водорослей, 13 - зеленых и 1 - красных. Новыми для флоры Кольского залива являются 11 видов. Большинство обнаруженных макроводорослей в губе Вересовая относятся к типично пресноводным, 4 вида распространены как в пресных, так и морских водах. Отмечены и морские виды, однако есть сомнения в их идентификации. Видовое разнообразие фитобентоса максимально в начале осени, минимально - зимой. 
Автор выражает глубокую признательность А.А. Фролову и коллегам из ММБИ за помощь при отборе проб, а также Е. Приймак за видовую идентификацию высших растений. Особая благодарность М.В. Макарову за ценные замечания при подготовке рукописи.

Работа выполнена в рамках государственного задания.

\section{Литература}

Голлербах М.М., Красавина Л.К. Определитель пресноводных водорослей СССР. Вып. 14. Харовые водоросли. Л.: Наука, 1983. 190 с.

Голлербах М.М., Косинская Е.К., Полянский В.И. Определитель пресноводных водорослей СССР. Вып. 2. Синезеленые водоросли. М.: Сов. наука, 1953. 652 с.

Дедусенко-Щеголева Н.Т., Матвиенко А.М., Шкорбатов Л.А. Определитель пресноводных водорослей СССР. Вып. 8. Зеленые водоросли. Класс вольвоксовые. Chlorophyta: Volvocineae. М.; Л.: Изд-во АН СССР, 1959. 230 с.

Завалко С.Е., Шошина Е.В. Многоуровневая морфофизиологическая оценка состояния фукусовых водорослей в условиях антропогенного загрязнения (Кольский залив, Баренцево море) // Вестн. Мурм. гос. техн. ун-та. 2008. Т. 11, №. 3. С. $423-431$.

Кольский залив: океанография, биология, экосистемы, поллютанты / Под. ред. Г.Г. Матишова. Апатиты: Изд-во КНЦ РАН, 1997. 265 с.

Комулайнен С.Ф. Структура и функционирование фитоперифитона в малых реках Восточной Фенноскандии: Автореф. дис. ... канд. биол. наук. Одесса, 2005. 25 c.

Комулайнен С.Ф. Альгологические исследования в озерно-речных системах Севера европейской части России // Альгология. 2007. № 17. С. 220-229.

Комулайнен С.Ф. Фитоперифитон рек Мурманской области: структура и использование при мониторинге // Экологические проблемы северных регионов и пути их решения: Тез. докл. VII Всерос. науч. конф. с междунар. участием, посвященной 30-летию Института проблем промышленной экологии Севера ФИЦ КНЦ РАН и 75-летию со дня рождения докт. биол. наук, проф. В.В. Никонова, Апатиты, 16-22 июня 2019 г. Апатиты: Изд-во КНЦ РАН, 2019. С. 136-137.

Малавенда С.В. Флора водорослей макрофитов Кольского залива (Баренцево море) // Вестн. Мурм. гос. техн. ун-та. 2018. Т. 21, №. 2. 245-252.

Малавенда С.В., Шавыкин А.А., Ващенко П.С. Оценка видового разнообразия макрофитобентоса для карт уязвимости Кольского залива от разливов нефти // Защита окружающей среды в нефтегазовом комплексе. 2017. № 1. C. 7-14.

Паламарь-Мордвинцева Г.М. Определитель пресноводных водорослей СССР. Вып. 11 (2). Зеленые водоросли. Класс конъюгаты. Порядок десмидиевые. Chloropyta: Conjugatophyceae, Desmidiales (2). Л.: Наука, 1982. 620 с.

Романов P.Е., Блинова И.В. Виды рода Nitella (Streptophyta: Charales) в Мурманской области // Turczaninowia. 2015. № 18. С. 17-25.

Руководство по методам гидробиологического анализа поверхностных вод и донных отложений / Под ред. В.А. Абакумова. Л.: Гидрометеоиздат, 1983. 239 с.

Руководство по гидробиологическому мониторингу пресноводных экосистем / Под ред. В.А. Абакумова. СПб.: Гидрометеоиздат, 1992. 317 с. 
DOI: $10.37614 / 2307-5252.2021 \cdot 3 \cdot 9.012$

УДК 574.34 (268.45)

\section{К.К. Москвин}

Мурманский морской биологический институт РАН, г. Мурманск, Россия

\section{ПОЛИХЕТЫ РОДА РНОLOE (POLYCHAETA: PHOLOIDAE) СЕВЕРО-ВОСТОЧНОЙ ЧАСТИ БАРЕНЦЕВА МОРЯ}

\section{Аннотация}

Исследованы видовой состав, особенности распределения, распространения и биологии полихет рода Pholoe в северо-восточной части Баренцева моря (между архипелагом Земля Франца-Иосифа и северо-западным побережьем архипелага Новая Земля). В данном районе исследований на основе обновленных морфологических описаний идентифицированы особи Pholoe assimilis. Установлено, что наибольших показателей плотности популяции (1130 экз/ $\left./ \mathrm{M}^{2}\right)$ и биомассы $\left(570 \mathrm{mr} / \mathrm{m}^{2}\right)$ полихеты данного вида достигают в относительно теплых прибрежных новоземельских водах. Впервые была проанализирована размерная структура популяций Pholoe assimilis северо-восточной части Баренцева моря по ширине пятого сегмента тела, что позволило установить присутствие особей четырех размерных классов.

Ключевые слова: полихеты, род Pholoe, экология, распространение, Баренцево море.

\section{K.K. Moskvin}

Murmansk Marine Biological Institute RAS, Murmansk, Russia

\section{POLYCHAETE GENUS PHOLOE (POLYCHAETA: PHOLOIDAE) IN THE NORTH-EAST REGION OF THE BARENTS SEA}

\section{Abstract}

The paper describes species composition, distribution and biology of the polychaeta genus Pholoe in the north-east region of the Barents Sea (between Franz Josef Land and north-west coast of Novaya Zemlya archipelago). One species of the genus was identified based on the reviewed morphological descriptions - Pholoe assimilis. The highest values of population density (1130 specimens $\left./ \mathrm{m}^{2}\right)$ and biomass $\left(570 \mathrm{mg} / \mathrm{m}^{2}\right)$ were registered in comparatively warm coastal waters of Novaya Zemlya archipelago. Pholoe assimilis' population size structure based on the dorsal width of the fifth chaetiger was investigated for the first time. Size-frequency histograms indicate presence of at least four size classes.

Keywords: polychaeta, genus Pholoe, ecology, distribution, Barents Sea.

Введение. Северо-восточная часть Баренцева моря, характеризующаяся сложным взаимодействием водных масс как арктического, так и атлантического происхождения, является сравнительно менее изученным 
районом исследований. Особенности распределения водных масс в данном районе оказывают непосредственное влияние на структуру донных сообществ и, в том числе, на распространение массовых видов многощетинковых червей. Хищные полихеты рода Pholoe, несмотря на сравнительно небольшие размеры (длина до 10 мм, ширина до 2 мм) и незначительный вклад в биомассу сообществ, являются одними из наиболее распространенных фоновых видов.

Достижения последних лет в области таксономии (Meißner et al., 2017, 2020) значительно упростили процесс видовой идентификации данной группы живых организмов. В указанных работах представлены обширные сведения по таксономии, морфологии и экологии шести видов многощетинковых червей рода Pholoe прибрежных вод Северной Европы и Гренландии. Авторами приведены обновленные таксономические ключи, в которых не только подтверждена достоверность классических систематических признаков, но и выделены дополнительные.

Широкое распространение и высокая частота встречаемости в арктических водах определяет данную группу живых организмов как потенциальный индикатор при мониторинге климатических изменений в Баренцевом море. Однако отсутствие сведений о популяционной биологии полихет рода Pholoe не позволяет достоверно связывать потенциальные изменения их плотности поселения и биомассы как изменения условий окружающей среды. Таким образом, цель данной работы - установление видового разнообразия полихет рода Pholoe в северо-восточной части Баренцева моря, определение особенностей их распространения и популяционной биологии.

Материал и методы. Пробы бентоса были взяты на 12 станциях в рамках комплексной экспедиции на НИС “Дальние Зеленцы” в Баренцево и Карское моря с 23 октября по 27 ноября 2019 г. (рис. 1). Для отбора использовали дночерпатель ван-Вина с площадью захвата $0.1 \mathrm{~m}^{2}$ в 3-кратной повторности. Размер ячеи нижнего сита при промывке грунта -0.5 мм. После промывки материал был зафиксирован в 4 \%-м растворе формалина, нейтрализованного тетраборатом натрия.

Станции выполнены в зоне влияния различных водных масс (таблица). Всего было проанализировано 446 экз. многощетинковых червей. В районе влияния прибрежных новоземельских вод распространены характерные для большей части Баренцева моря зеленовато-серые грунты. Между архипелагами Новая Земля и Земля Франца-Иосифа осадки представлены характерными для северо-восточной части Баренцева и Карского морей окисленными коричневыми донными осадками (Денисенко, 2013). Поселения полихет прибрежья Новой Земли и полихет коричневых грунтов принадлежат к разным биоценозам.

При видовой идентификации полихет рода Pholoe применяли стереоскопический микроскоп Motic K-400L и бинокулярный микроскоп ЛОМО БИМАМ Р-11-1, а также руководствовались обновленными таксономическими ключами (Meißner et al., 2020). 


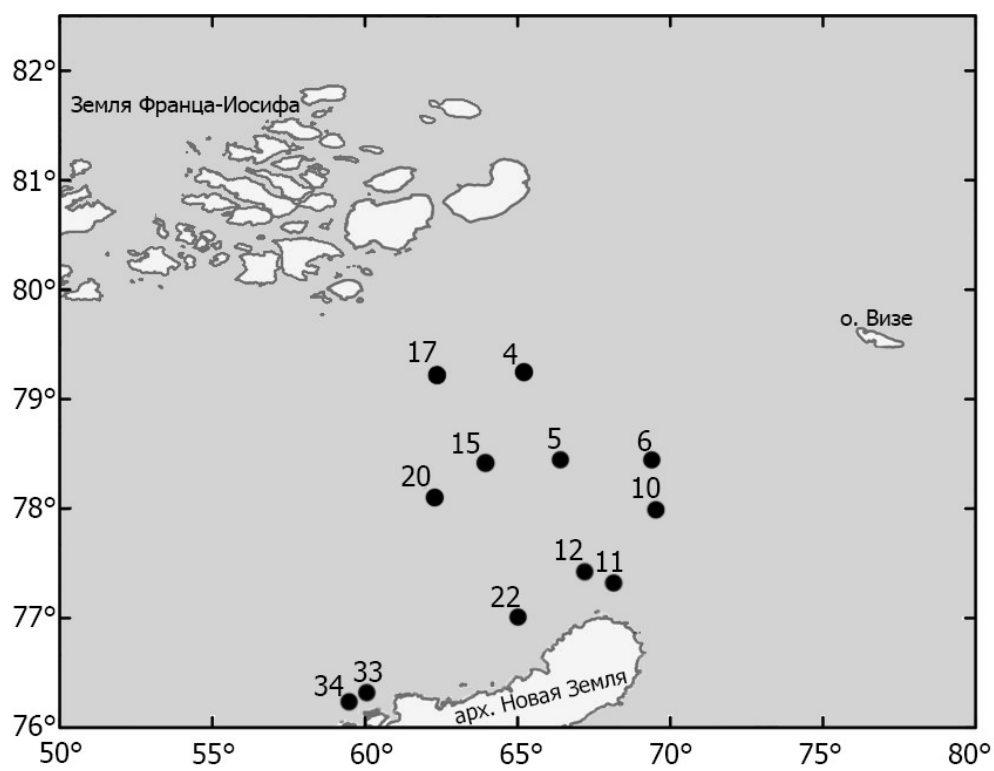

Рис. 1. Карта-схема района исследований

Fig. 1. Map of the research area

Характеристика среды в районе исследований

Characteristics of stations in the research area

\begin{tabular}{|c|c|c|c|}
\hline \multirow[b]{2}{*}{ Характеристика } & \multicolumn{3}{|c|}{ Водные массы } \\
\hline & $\begin{array}{c}\text { баренцевоморские } \\
\text { трансформированные }\end{array}$ & $\begin{array}{c}\text { прибрежные } \\
\text { новоземельские }\end{array}$ & арктические \\
\hline Номера станций & $5,6,10-12,15,20$ & $22,33,34$ & 4,17 \\
\hline Глубина, м & $343-507$ & $105-127$ & $186-427$ \\
\hline Температура, ${ }^{\circ} \mathrm{C}$ & $-0.3 \ldots-0.1$ & $-0.1-0.8$ & $-1.2 \ldots-0.25$ \\
\hline Соленость, psu & 34.9 & $34.8-34.9$ & $34.7-34.8$ \\
\hline Содержание $\mathrm{O}_{2}, \%$ & 84 & $87-88$ & 84 \\
\hline Тип грунта & $\begin{array}{l}\text { Коричневый ил или } \\
\text { песчанистый ил, } \\
\text { мягкая коричневая } \\
\text { глина }\end{array}$ & $\begin{array}{l}\text { Средне- и крупно- } \\
\text { зернистый песок, } \\
\text { серая вязкая глина }\end{array}$ & $\begin{array}{l}\text { Коричневый } \\
\text { песчанистый ил, } \\
\text { серая плотная и } \\
\text { коричневая мягкая } \\
\text { глина }\end{array}$ \\
\hline $\begin{array}{l}\text { Количество } \\
\text { полихет, экз. }\end{array}$ & 101 & 344 & 1 \\
\hline
\end{tabular}

ПРИМЕЧАНИЕ. Температура и соленость указаны для придонного слоя воды.

В каждой пробе были вычислены плотность поселения (экз $\left./ \mathrm{M}^{2}\right)$, биомасса $\left(\mathrm{мг} / \mathrm{M}^{2}\right)$ и частота встречаемости полихет рода Pholoe. Выполнен корреляционный анализ влияния глубины, температуры воды и биотических факторов (плотности поселения его потенциальных объектов питания, биоценообразующих видов) на их плотность поселения. 
Для изучения размерной структуры популяции, согласно ранее разработанной методике (Heffernan, 1985), проведены замеры ширины пятого сегмента тела. Для измерений использовали стереоскопический микроскоп МБС-10. Особи с одинаковыми показателями ширины пятого сегмента тела были объединены в группы, в дальнейшем определялась доля каждой группы относительно всех особей, отобранных на станции. По рассчитанным долям составлены размерно-структурные гистограммы, отображающие особенности размерной структуры популяции полихет рода Pholoe в октябре-ноябре в северо-восточной части Баренцева моря. По пикам на размерно-структурных гистограммах выделены примерные возрастные генерации.

Результаты и обсуждение. По результатам видовой идентификации было установлено, что из шести видов, зарегистрированных в прибрежных водах Северной Европы (Meißner et al., 2020), в северо-восточной части Баренцева моря обитает только Pholoe assimilis Örsted, 1845. Данный вид характеризуется наименьшими средними размерами половозрелых особей относительно других представителей рода (длина 2.1-5.1 мм, ширина 0.61 мм). Основными таксономическими признаками являются отсутствие фациальной туберкулы, латеральных антенн и пигментации элитр. Последние, в свою очередь, полностью покрывают дорсальную сторону тела, дистально расположенные на них папиллы длинные, тонкие, четковидные (Meißner et al., 2020).

В районе исследований полихеты Pholoe assimilis в целом характеризуются одним из наибольших показателей частоты встречаемости (83 \%), уступая только полихетам семейств Lumbrineridae (100\%) и Cirratulidae (91.7 \%), а также Spiochaetopterus typicus (91.7 \%), который не был зарегистрирован только на станциях 4 и 20. Несмотря на то, что указанные станции являются глубоководными (427 м и 392 м соответственно), в районе исследований полихеты рода Pholoe были зарегистрированы на глубине вплоть до 502 м, поэтому отсутствие на них Pholoe assimilis может быть связано с пониженным содержанием кислорода у дна. Средняя плотность поселения для Pholoe assimilis, обитающих на зеленовато-серых грунтах, омываемых прибрежными новоземельскими водами, составляет 513 экз $/ \mathrm{M}^{2}$, а для полихет коричневых грунтов склонов желобов Святая Анна и Северо-Восточный плотность поселения ниже на $92 \%-42$ экз/ $\mathrm{M}^{2}$.

Установлено, что наибольших показателей плотность популяции (1133 экз $\left./ \mathrm{M}^{2}\right)$ и биомасса $\left(566.7 \mathrm{~m} / \mathrm{m}^{2}\right)$ Pholoe assimilis достигают в прибрежных новоземельских водах (рис. 2). Данный район отличается не только сравнительно высокими температурами $\left(-0.1-0.8{ }^{\circ} \mathrm{C}\right)$, но и наименьшими глубинами (106-127 м). Он характеризуется большим разнообразием экологических ниш и более высоким содержанием органического вещества (1-2 \% углерода) в донных осадках (Горшкова, 
1939), что обусловливает высокие численность и биомассу бентосных организмов и, как следствие, более обширную кормовую базу для Pholoe assimilis. Перечисленные особенности благоприятны для жизнедеятельности этих полихет, поэтому наибольшей плотности популяции данный вид достигает в прибрежье Новой Земли.
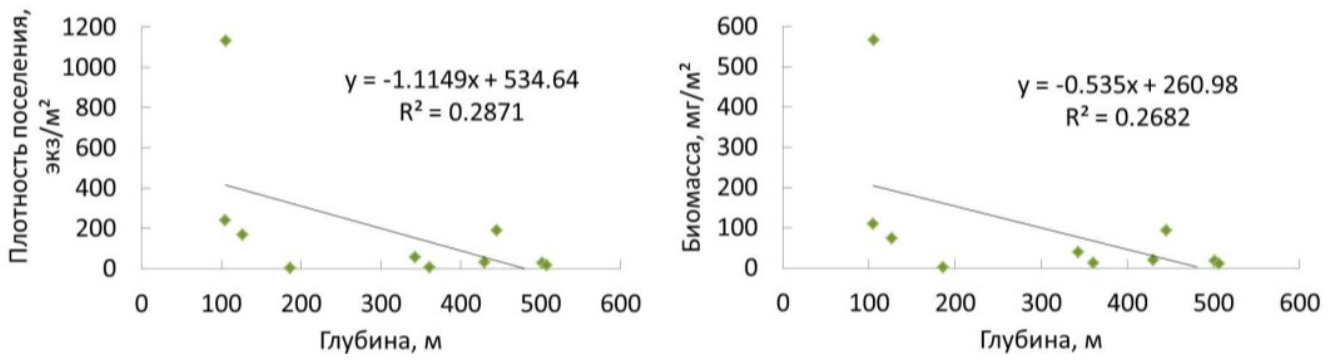

Рис. 2. Изменение плотности популяции и биомассы Pholoe assimilis в зависимости от глубины в районе исследований

Fig. 2. The tendency of changes in population density and biomass of Pholoe assimilis in relation to depth in the research area

Максимальная плотность популяции Pholoe assimilis, обитающей в районах влияния баренцевоморских трансформированных вод, ниже на $83 \%$ (190 экз $\left./ \mathrm{m}^{2}\right)$, а биомасса - на $84 \%\left(93.3 \mathrm{мг} / \mathrm{m}^{2}\right)$. Это связано с тем, что в данном районе исследований имеет место увеличение глубины (до 502 м), являющейся основным лимитирующим фактором при распространении полихет рода Pholoe. Однако на глубине 445 м (ст. 10) наблюдается резкое повышение их плотности популяции (рис. 3).

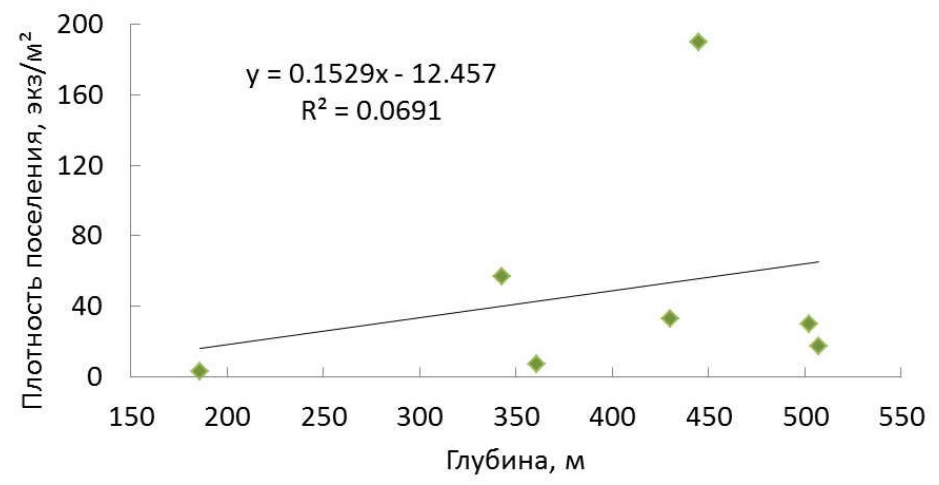

Pис. 3. Изменение плотности популяции Pholoe assimilis на коричневых грунтах в зависимости от глубины

Fig. 3. The tendency of changes in population density of Pholoe assimilis in relation to depth on the brown bottom types

На станциях, расположенных в районе холодных арктических вод, где придонная температура достигала $-1.2{ }^{\circ} \mathrm{C}$, были зарегистрированы единичные экземпляры Pholoe assimilis (рисунки 4, 5). 


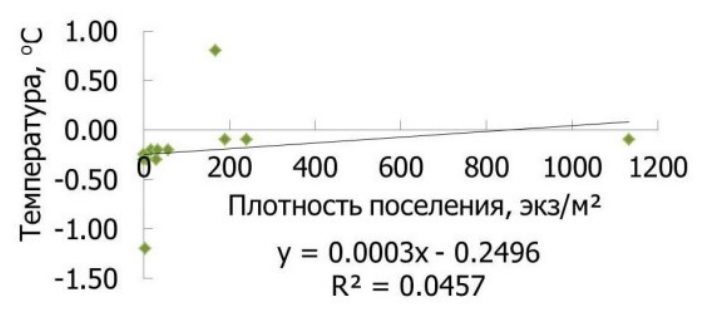

Рис. 4. Изменение плотности популяции Pholoe assimilis в зависимости от придонной температуры воды в районе исследований

Fig. 4. The tendency of changes in population density of Pholoe assimilis in relation to temperature in the research area overall

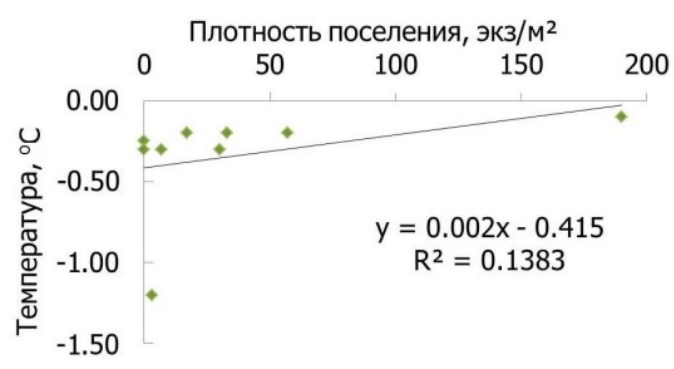

Рис. 5. Изменение плотности популяции Pholoe assimilis на коричневых грунтах в зависимости от придонной температуры воды

Fig. 5. The tendency of changes in population density of Pholoe assimilis in relation to temperature on the brown bottom types

Анализируемые особи Pholoe assimilis были отобраны на станциях с относительно схожими показателями солености (34.7-34.9 \%о), в связи с этим влияние данного фактора не рассматривалось. Таким образом, достоверной связи между влиянием абиотических факторов и изменением плотности поселения исследуемых полихет установлено не было, о чем свидетельствуют низкие показатели коэффициента детерминации (рисунки 2-5). Однако установленные тенденции свидетельствуют о том, что с увеличением глубины и понижением придонной температуры наблюдается снижение плотности популяции и биомассы полихет Pholoe assimilis. Подобная динамика может быть наглядно продемонстрирована при сравнении средних показателей плотности популяции для станций, находящихся под влиянием трех водных масс (рис. 6). В районе влияния арктических вод с наименьшими зарегистрированными придонными температурами, что не является благоприятными условиями для жизнедеятельности полихет рода Pholoe, плотность их популяции минимальна - 3 экз $/ \mathrm{M}^{2}$.

В районах исследований обнаружена высокая степень корреляции между плотностью поселения в популяции Pholoe assimilis и таковой y Philomedes globosus $\left(\mathrm{R}^{2}=0.93\right)$, Macoma calcarea $\left(\mathrm{R}^{2}=0.88\right)$, Eteone agg. flava $\left(\mathrm{R}^{2}=0.84\right)$ и Cossura longocirrata $\left(\mathrm{R}^{2}=0.68\right)$. Наши данные 
соответствуют зарегистрированным ранее сведениям об особенностях питания полихет рода Pholoe (Pleijei, 1982). Основными объектами питания объекта исследования являются преимущественно мелкие полихеты, ракообразные и двустворчатые моллюски. Таким образом, молодь указанных видов может выступать в качестве пищи для полихет этого рода. Следовательно, повышение плотности их популяций приводит к повышению таковой Pholoe assimilis. Данное предположение требует дальнейшего подтверждения посредством более подробного изучения особенностей питания полихет рода Pholoe в Баренцевом море.

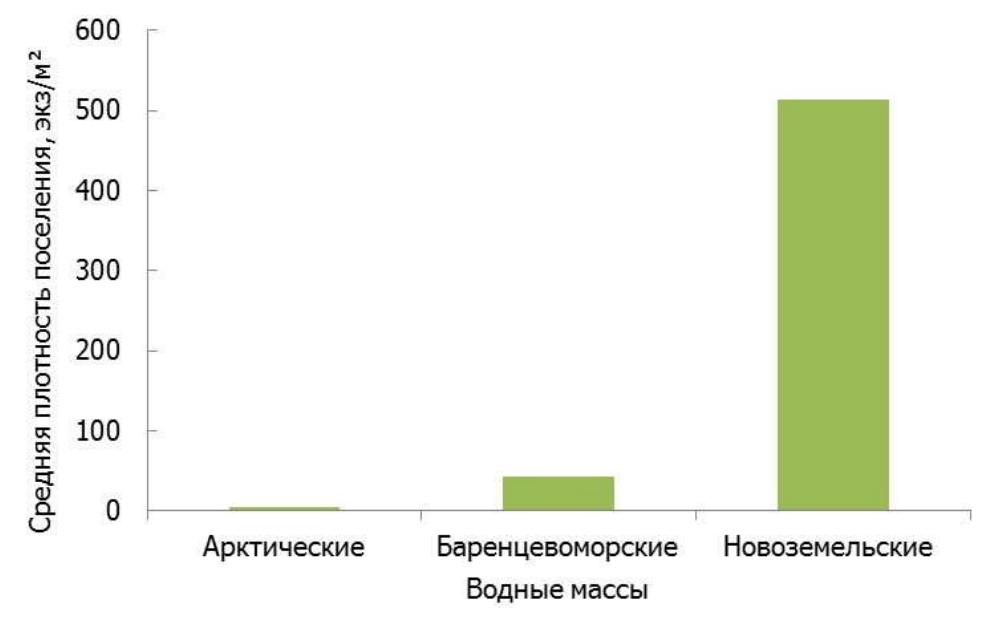

Рис. 6. Средняя плотность поселения полихет Pholoe assimilis при влиянии разных водных масс

Fig. 6. Average population density of Pholoe assimilis in relation to the water masses affecting their habitat

Впервые была проанализирована размерная структура популяций Pholoe assimilis северо-восточной части Баренцева моря по ширине пятого сегмента тела. В прибрежных новоземельских водах минимальный размер особей достигал 186 мкм, максимальный - 586 мкм. Размерные значения особей баренцевоморких вод, в свою очередь, варьировали в большем диапазоне. Здесь минимальный размер особей составил 171 мкм, а максимальный - 714 мкм. Несмотря на более широкий размерный диапазон, на большинстве станций в данном районе исследований молодь отсутствовала, что может быть объяснено ее низкой выживаемостью в сравнительно менее благоприятных условиях для жизнедеятельности. Также стоит учитывать, что ввиду мелких размеров ранняя молодь Pholoe assimilis может не задерживаться в промывочном сите, поэтому определить точную долю особей до года не представляется возможным.

Полимодальное распределение на размерно-частотных гистограммах (рис. 7) указывает на присутствие в пробах как минимум четырех размерных классов: особей с шириной пятого сегмента тела до 200, 200$350,350-450$ и более 450 мкм.

94 

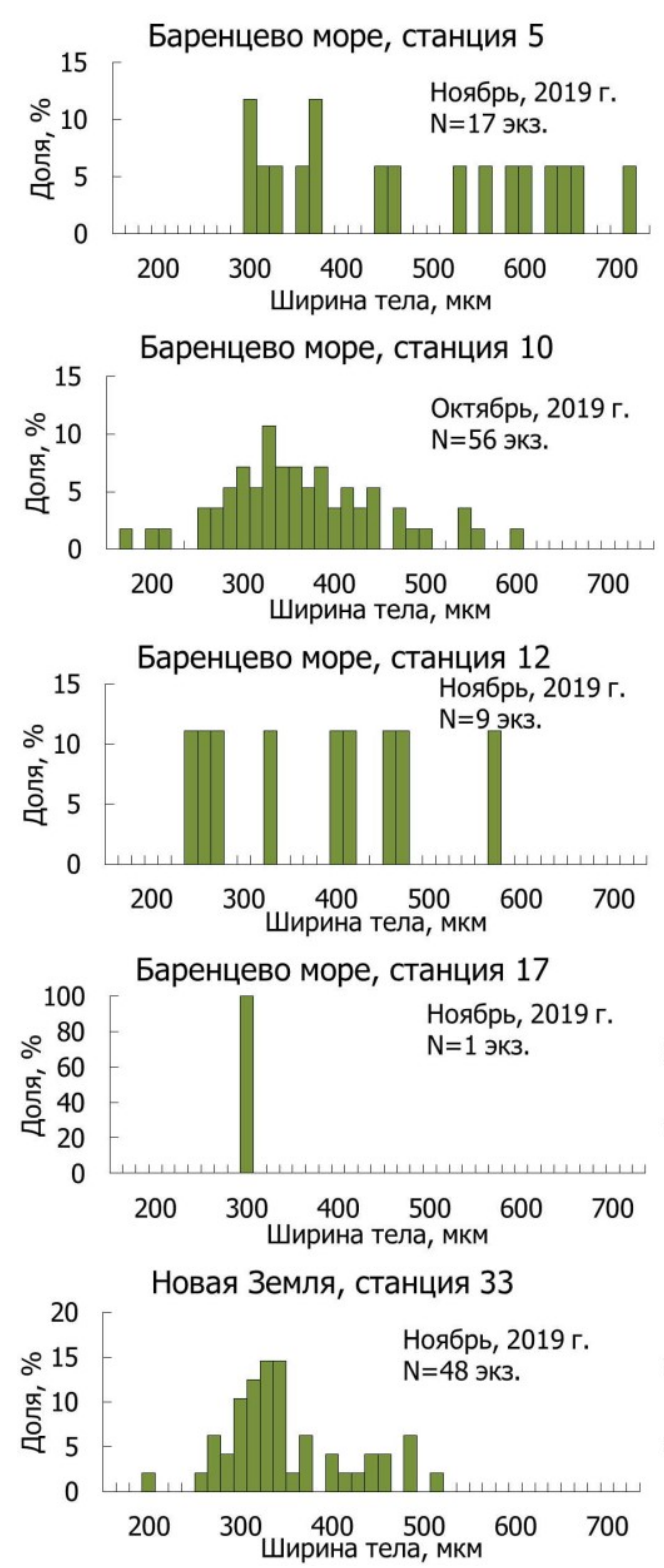
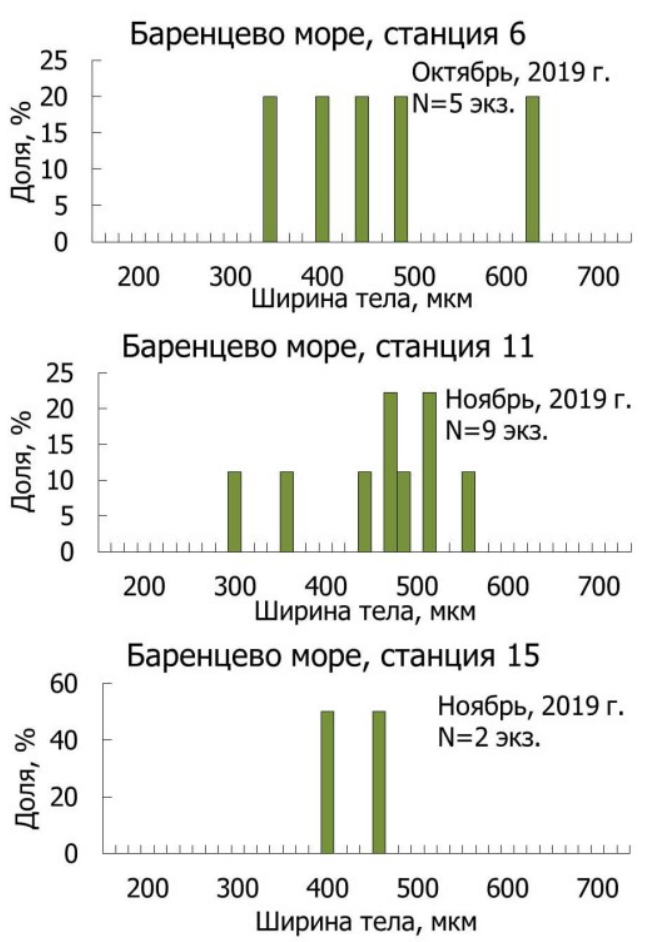

Новая Земля, станция 22

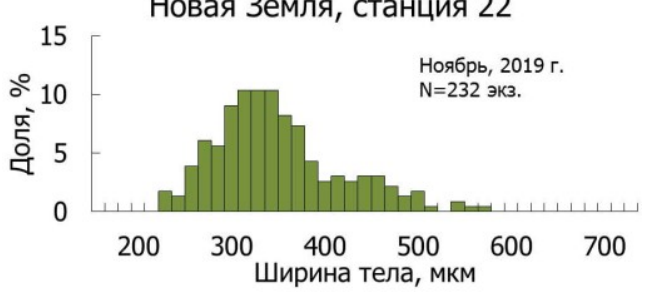

Новая Земля, станция 34

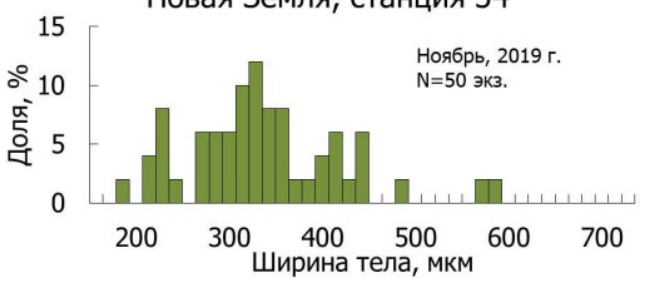

Рис. 7. Размерно-частотные гистограммы Pholoe assimilis, характеризующие структуру поселений в октябре-ноябре 2019 г.

Fig. 7. Pholoe assimilis, size-frequency histograms characterizing sample obtained in October-November, 2019

Несмотря на различия абиотических условий на станциях со сравнительно высокой численностью особей (ст. 10 - баренцевоморские трансформированные воды; станции 22, 33, 34 - прибрежные новоземельские воды), рослеживаются схожие закономерности в размерной структуре. В данных районах большую долю составляют особи 
с шириной пятого сегмента тела, равного 330 мкм, а также в распределении наблюдаются дополнительные пики при ширине 400 мкм. Отсутствие особенно крупных особей (714 мкм) на указанных станциях может быть связано и с выеданием их прочими хищниками. Это может свидетельствовать и о повышении конкуренции в районах с большей плотностью поселения полихет Pholoe assimilis. Особям баренцевоморских водных масс, обитающим в менее благоприятных условиях и способным пройти ранние этапы жизненного цикла, не приходится конкурировать с молодью за объекты питания, что позволяет достичь больших размеров.

Дальнейшие исследования в области популяционной биологии, а именно анализ возрастной структуры в зависимости от сезона, помогут установить достоверные возрастные классы полихет рода Pholoe в Баренцевом море и, как следствие, уточнить особенности их размножения.

Заключение. В северо-восточной части Баренцева моря обитает один представитель многощетинковых червей рода Pholoe - Pholoe assimilis. Несмотря на то, что особи данного вида могут обитать в широких диапазонах изменения условий окружающей среды, наибольших плотности поселения и биомассы они, как и представители прочих видов данного рода, достигают в прибрежных новоземельских водах на относительно малых глубинах и при положительных температурах придонных вод. Также для хищных полихет рода Pholoe важным условием для жизнедеятельности является доступность питания, поэтому в районах с высокой численностью жертв и большим числом экологических ниш их плотность поселения максимальна. Низкие температуры также являются одним из факторов, ограничивающим распространение полихет Pholoe assimilis. Анализ влияния биотических факторов позволил установить потенциальных объектов питания этих полихет в Баренцевом море. В структуре поселений Pholoe assimilis были выделены четыре размерные группы.

Автор выражает благодарность с.н.с. лаборатории зообентоса ММБИ РАН Л.В. Павловой за ценные замечания при написании работы.

Работа выполнена по теме 9-19-01 “Донные сообщества Баренцева моря, его водосборного бассейна и сопредельных вод: экология, биоразнообразие, роль чужеродных видов" в рамках государственного задания (№ 0228-2019-0025).

\section{Литература}

Горикова Т.И. Органическое вещество и карбонаты в осадках Баренцева моря // Тр. ВНИРО. 1939. Т. IV, вып. 1. С. 71-108.

Денисенко С.Г. Биоразнообразие и биоресурсы макрозообентоса Баренцева моря: структура и многолетние изменения. СПб.: Наука, 2013. 284 с.

Heffernan P. Demography of Pholoe minuta (Polychaeta: Sigalionidae) in Galway Bay, west coast of Ireland, with special reference to settlement and recruitment patterns // Marine Biology. 1985. Vol. 84. P. 323-329. 
Meißner K., Bick A., Götting M. Arctic Pholoe (Polychaeta: Pholoidae): when integrative taxonomy helps to sort out barcodes // Zool. J. Linnean Society. 2017. Vol. 179, iss. 2. P. 237-262.

Meißner K., Götting M., Nygren A. Do we know who they are? On the identity of Pholoe (Annelida: Sigalionidae: Pholoinae) species from northern Europe // Zool. J. Linnean Society. 2020. Vol. 189, iss. 1. P. 1-29.

Pleijel F. On feeding of Pholoe minuta (Fabricus, 1780) (Polychaeta: Sigalioinidae) // Sarsia. 1983. Vol. 68. P. 21-23.

DOI: $10.37614 / 2307-5252.2021 .3 .9 .013$

УДК 591.1:591.16

А.Э. Носкович

Мурманский морской биологический институт РАН, г. Мурманск, Россия

ОСОБЕННОСТИ РАСПРЕДЕЛЕНИЯ И БИОЛОГИИ

ДВУСТВОРЧАТОГО МОЛЛЮСКА МАСОМА САLCAREA (GMELIN, 1791)

В ЗАЛИВЕ ГРЁН-ФЬОРД (АРХИПЕЛАГ ШПИЦБЕРГЕН)

\section{Аннотация}

Установлены особенности распределения и биологии двустворчатого моллюска Macoma calcarea в заливе Грён-фьорд (арх. Шпицберген) в 2015 г. Выявлена тенденция уменьшения общей численности моллюсков и доли молоди с увеличением глубины. Скорость роста в первые годы жизни практически одинаковая во всех частях фьорда. Повсеместно отмечено преобладание самок над самцами. В целом условия для размножения, питания и роста моллюсков более благоприятны в куту, чем в других частях фьорда.

Ключевые слова: двустворчатый моллюск, Шпицберген, Грён-фьорд, обилие, размерновозрастной состав, темпы роста, половая структура.

\section{A.E. Noskovich \\ Murmansk Marine Biological Institute RAS, Murmansk, Russia \\ DISTRIBUTION AND BIOLOGY OF THE BIVALVE MACOMA CALCAREA (GMELIN, 1791) IN THE GRENFJORDEN (SVALBARD)}

\section{Abstract}

The features of distribution and biology of the bivalve mollusk Macoma calcarea in the Grenfjorden arch are established in 2015. A tendency to decrease the total number of mollusks and the proportion of juveniles with increasing depth was revealed. The growth rate in the first years of life is almost the same in all parts of the fjord. 
The predominance of females over males is noted everywhere. In general, conditions for the reproduction, nutrition and growth of mollusks in Kutu inner part are more favorable than in other parts of the fjord.

Keywords: bivalve, Svalbard, Grenfjorden, abundance, size and age composition, growth rate, sexual structure.

Введение. Архипелаг Шпицберген расположен в шельфовой зоне на стыке взаимодействия атлантических и арктических вод. Во фьорды Западного Шпицбергена в результате таяния ледников поступают холодные пресные воды с большим количеством минеральной взвеси и моренного материала (Матишов, 1984; Митяев, Герасимова, 2003; Тарасов, 2009). Со стороны океана в заливы проникают теплые соленые атлантические воды. Эта особенность гидрологического режима фьордов Шпицбергена определяет интерес к исследованию закономерностей распределения здесь донных организмов.

Грён-фьорд расположен в южной части залива Ис-фьорд (Западный Шпицберген), у выхода в Гренландское море. Он ориентирован с юга на север и имеет протяженность около 16.5 км, его ширина меняется от 1.8 км в кутовой части до 5.4 км на границе с Ис-фьордом, а глубина постепенно увеличивается от 50 м в кутовой части до 170 м на выходе из фьорда (Результаты ..., 2007).

Macoma calcarea - широко распространенный бореальноарктический циркумполярный вид двустворчатых моллюсков. География распространения данного вида достаточно обширна, его представители обнаружены во всех северных морях России (Наумов, 2006). Для данного вида характерно образование плотных поселений с биомассой свыше

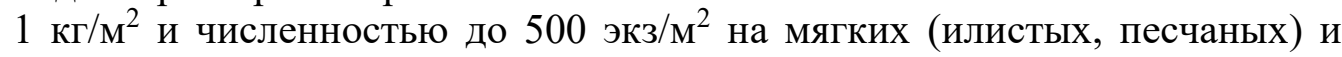
смешанных грунтах (Филатова, Зенкевич, 1957; Федяков, 1986; Наумов, 2006; Бритаев и др., 2010). Так как Macoma calcarea играет важную роль в морских экосистемах, для прогнозирования возможных изменений, вызванных климатическими флуктуациями или антропогенным воздействием, необходимы данные об основных показателях ее биологии.

Несмотря на широкое распространение и обилие этого вида моллюсков, некоторые аспекты биологии были изучены только в Белом, Карском и Печорском морях (Золотарев, 1989; Юргенс, 2006; Лисицына, Герасимова, 2018), а размножение и половая структура изучались лишь в 1930-1970-х гг. в водах Гренландии и Балтийского моря (Thorson, 1936; Coe, 1943; Ockelmann, 1958; Oertzen, 1972). Сведения о популяционных характеристиках Macoma calcarea в водах архипелага Шпицберген отсутствуют.

В геоморфологическом строении залива Грён-фьорд выделяют две области - внешнюю и внутреннюю, граница между ними проходит по линии соединяющей мыс Ларвик и устье р. Сандефьорднесел (Митяев и др., 2005). Воздействие современных ледников на внешнюю область 
залива Грён-фьорд незначительно, в отличие от внутренней кутовой части, которая подвержена интенсивному воздействию современных ледников (Митяев и др., 2005). В условиях такой динамической структуры водной массы могут формироваться поселения Macoma calcarea с различными характеристиками.

Цель работы - установить особенности распределения и биологии в поселениях двустворчатого моллюска Macoma calcarea в различных областях залива Грён-фьорд.

Материал и методы. Материал, использованный в работе, был собран сотрудниками Мурманского морского биологического института РАН на 5 станциях в разных частях залива Грён-фьорд (арх. Шпицберген) в ноябре-декабре 2015 г. (рис. 1). Внешняя область залива в нашем исследовании включает в себя открытую (станции 47, 48) и среднюю (станции 49, 50) части фьорда, а внутренняя - кутовую часть (ст. 51). Пробы собирали с помощью дночерпателя ван-Вина (площадь захвата $0.1 \mathrm{~m}^{2}$ ) в трехкратной повторности. Грунт промывали через сито с размером ячеи 0.5 мм и фиксировали $4 \%$-м раствором формалина; после сортировки пробы переводили в 75 \%-й раствор этилового спирта.

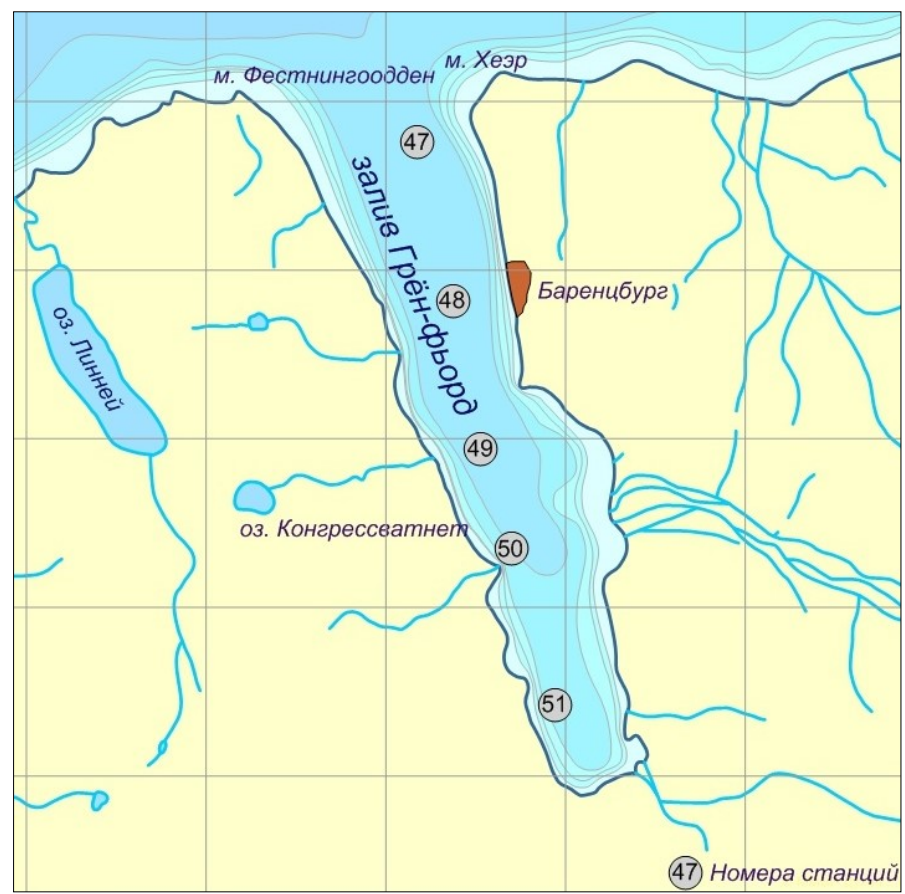

Рис. 1. Карта-схема мест отбора проб

Fig. 1. The map of the sampling sites

В 2020 году из проб отобрали моллюсков Macoma calcarea для дальнейшей обработки. Всего был изучен 221 моллюск. У каждой особи штангенциркулем измеряли длину раковины с точностью до 0.1 мм, у мелких экземпляров - с помощью окулярной линейки бинокулярного 
микроскопа. Возрастные изменения длины тела оценивали по конечному размеру группы разновозрастных особей, а ежегодный прирост по разнице смежных величин конечной длины раковины в последовательном ряду возрастов (Методы ..., 1990). Определяли прирост в первые годы жизни (до наступления половозрелости) и после достижения половой зрелости, рассчитывали средние показатели прироста за годы жизни.

Пол моллюсков определяли под микроскопом "Микмед-6" по числу и строению половых клеток в гонадах. Если при вскрытии моллюска гонады отсутствовали, считали, что данный моллюск неполовозрелый.

Для сравнения выборок по размерно-возрастному составу моллюсков использовали непараметрический критерий Манна-Уитни (уровень значимости $p \leq 0.05$ ). Соответствие соотношения половозрелых и неполовозрелых особей проверяли на основе критерия $\chi^{2}$ Пирсона (Ивантер, Коросов, 2003). Для картографического изображения участков сбора проб использовали программу Map Viewer 8.

Результаты и обсуждение. Особи Macoma calcarea были обнаружены на четырех станциях, на ст. 48 на глубине 147 м данный вид моллюсков обнаружен не был. В водах архипелага Шпицберген биомасса и плотность поселения Macoma calcarea были распределены неравномерно (таблица). Минимальное значение биомассы отмечено в открытой части фьорда на глубине 125 м, максимальное - в средней части фьорда на большей глубине и более высокой температуре. Максимальную плотность поселения моллюски формировали в кутовой части (таблица).

\section{Объем материала, характеристика поселений Macoma calcarea и района отбора проб Volume of material analyzed, characteristics of settlements Macoma calcarea and sampling areas}

\begin{tabular}{|c|c|c|c|}
\hline Показатель & $\begin{array}{c}\text { Открытая часть } \\
\text { залива } \\
\end{array}$ & $\begin{array}{c}\text { Средняя часть } \\
\text { залива } \\
\end{array}$ & Кут залива \\
\hline Количество & 54 & 45 & 122 \\
\hline 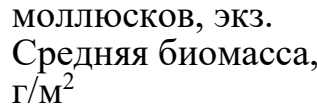 & $40.0 \pm 0.4$ & $84.0 \pm 0.9$ & $67.0 \pm 0.4$ \\
\hline $\begin{array}{l}\text { Плотность } \\
\text { поселений, экз/м² }\end{array}$ & $180.0 \pm 2.1$ & $150.0 \pm 1.9$ & $406.0 \pm 3.2$ \\
\hline Глубина, м & $123.0-125.0$ & $128.0-149.0$ & 87.0 \\
\hline $\begin{array}{l}\text { Придонная } \\
\text { температура, }{ }^{\circ} \mathrm{C}\end{array}$ & 4.2 & $4.4-4.7$ & $4.4-4.7$ \\
\hline Соленость, \%о & 34.7 & $34.7-34.8$ & 34.5 \\
\hline Грунт & $\begin{array}{l}\text { Светло-коричневый } \\
\text { ил, камни }\end{array}$ & $\begin{array}{l}\text { Светло-коричневый } \\
\text { ил, песок, темно- } \\
\text { серая и черная } \\
\text { глина, камни, } \\
\text { галька, ракуша }\end{array}$ & $\begin{array}{l}\text { Светло-коричневый } \\
\text { ил, серо-черная } \\
\text { мягкая глина, камни }\end{array}$ \\
\hline
\end{tabular}

ПРИМЕЧАНИЕ. Для биомассы и плотности поселений приведена ошибка среднего. 
В Грён-фьорде были обнаружены моллюски Macoma calcarea с длиной раковины от 0.8 до 29.3 мм. Молодь доминировала в кутовой части залива (68\%), в средней она практически не встречалась (4\%), а в открытой части залива составляла $30 \%$ от выборки (рис. 2). Сравнение размерного состава моллюсков из кута со средней и открытой частями Грён-фьорда показывает, что различия статистически значимы (критерий Манна-Уитни: $\left.U_{\text {эмп }}<U_{\text {кр}} ; p \leq 0.05\right)$.

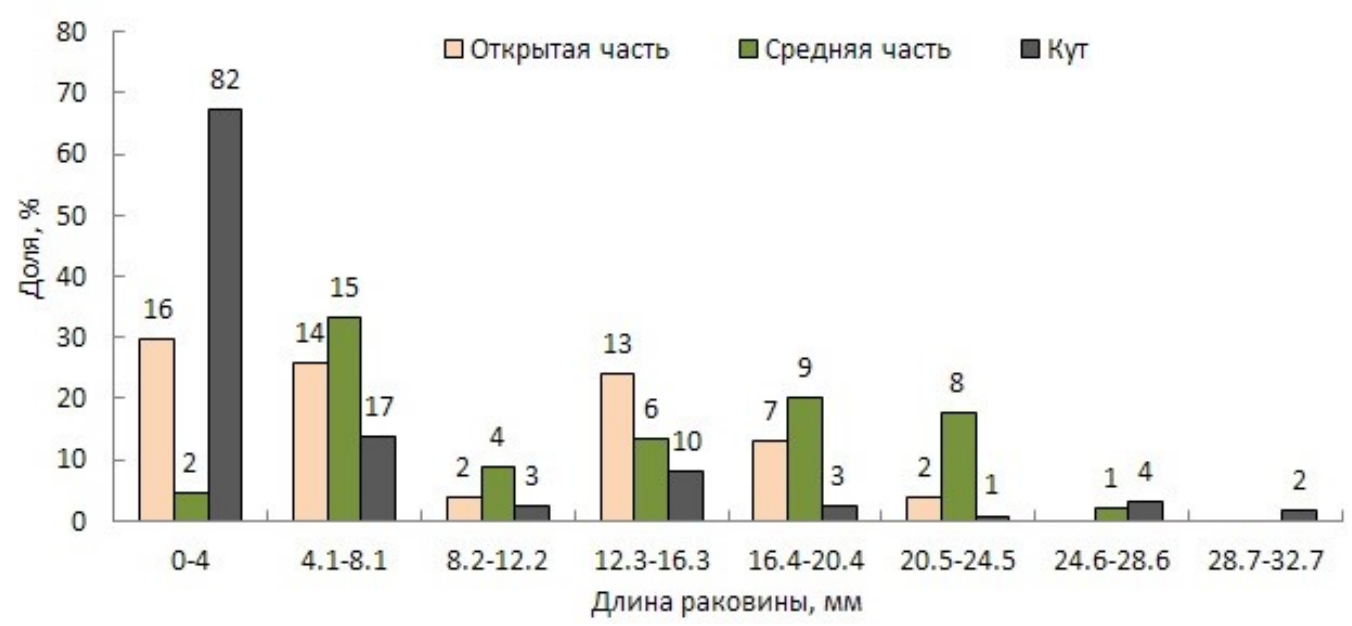

Рис. 2. Размерный состав поселений Macoma calcarea в заливе Грён-фьорд

Fig. 2. The size structure of Macoma calcarea aggregations in the Grenfjorden

Максимальная продолжительность жизни Macoma calcarea была отмечена у особей в куту - 18 лет. Основная часть поселений в этом районе Грён-фьорда (68 \%) представлена годовиками. Возраст моллюсков в открытой и средней частях фьорда несколько меньше - 14-15 лет (рис. 3). Сравнение показало незначимое различие возрастного состава в разных районах фьорда (критерий Манна-Уитни: $U_{\text {эмп }}>U_{\text {кр }} p \leq 0.05$ ).

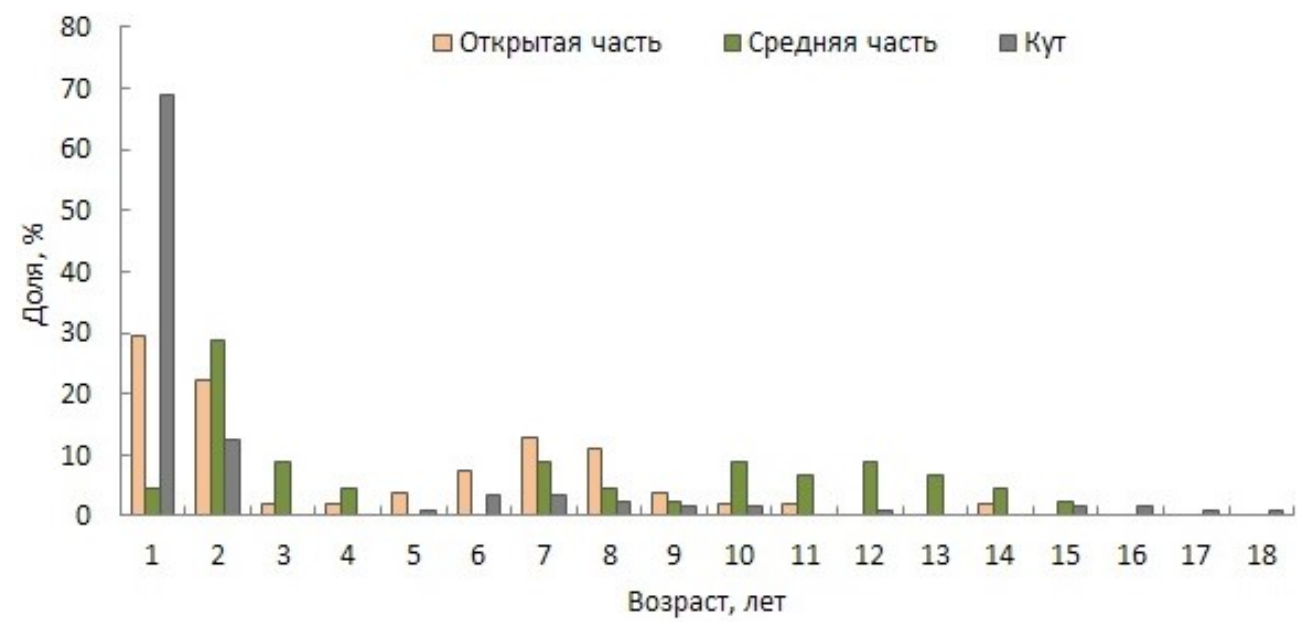

Рис. 3. Возрастной состав поселений Macoma calcarea в заливе Грён-фьорд

Fig. 3. The age structure of Macoma calcarea aggregations in the Grenfjorden 
Продолжительность жизни Macoma calcarea в северных морях изучалась многими исследователями. Наибольшая продолжительность жизни отмечена нами на востоке Баренцева моря (у берегов Новой Земли) 26 лет (Носкович, 2018). В юго-западной части Карского моря были найдены моллюски в возрасте 18-20 лет (Лисицына, Герасимова, 2018). В Балтийском море встречались моллюски в возрасте 14 лет (Юргенс, 2006). Для Баренцева и Карского морей продолжительность жизни указывается в 15 лет (Золотарев, 1989), а для вод Западной Гренландии 17 лет (Petersen, 1978).

Средняя скорость роста моллюсков в первые годы жизни практически одинакова во всех частях Грён-фьорда (рис. 4). В куту и открытой части залива моллюски после 6 лет растут не равномерно, а скачкообразно, по сравнению с средней частью фьорда, при этом различия статистически не значимы (критерий Манна-Уитни: $U_{\text {эмп }}>U_{\text {кр }} ; p \leq 0.05$ ).

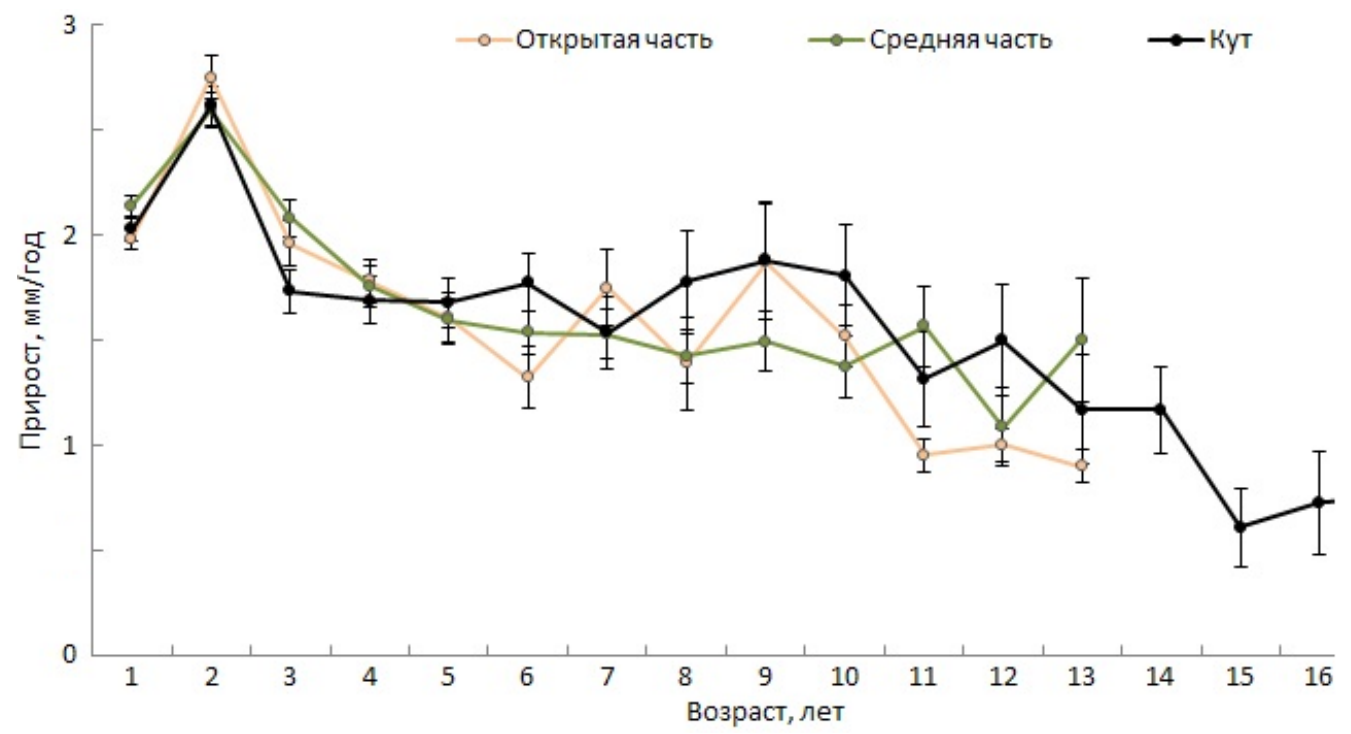

Рис. 4. Возрастные изменения ежегодного прироста длины раковины у моллюсков Fig. 4. Age-related variations in annual increase in shell length of clam

Сведений о линейном росте Macoma calcarea в разных районах их распространения крайне мало. Рост в первые годы жизни у недостигших половой зрелости особей наиболее интенсивно проходит в южной части Баренцева моря - 3 мм/год (Носкович, 2018), чуть медленнее моллюски растут в заливе Грён-фьорд (арх. Шпицберген) - 2.4 мм/год, а у берегов Новой Земли - 2.1 мм/год (Носкович, 2021). Macoma calcarea из Печорского и Карского морей отличались весьма низкой скоростью роста на ранних этапах развития - 1 мм/год (Лисицына, Герасимова, 2018; Distribution ..., 2019). Наши данные по среднегодовому приросту 1.5 мм/год - схожи с показателями для вод Западной Гренландии (Petersen, 1978) и восточной части Баренцева моря (Носкович, 2018), где прирост также составляет около 1.5 мм/год. 
В куту залива количественно преобладали неполовозрелые моллюски, в отличие от открытой и средней части Грён-фьорда, где доминировали половозрелые особи (рис. 5А), при этом данные различия статистически достоверны (критерий $\chi^{2} \geq \chi^{2}, p=0.05$ ).
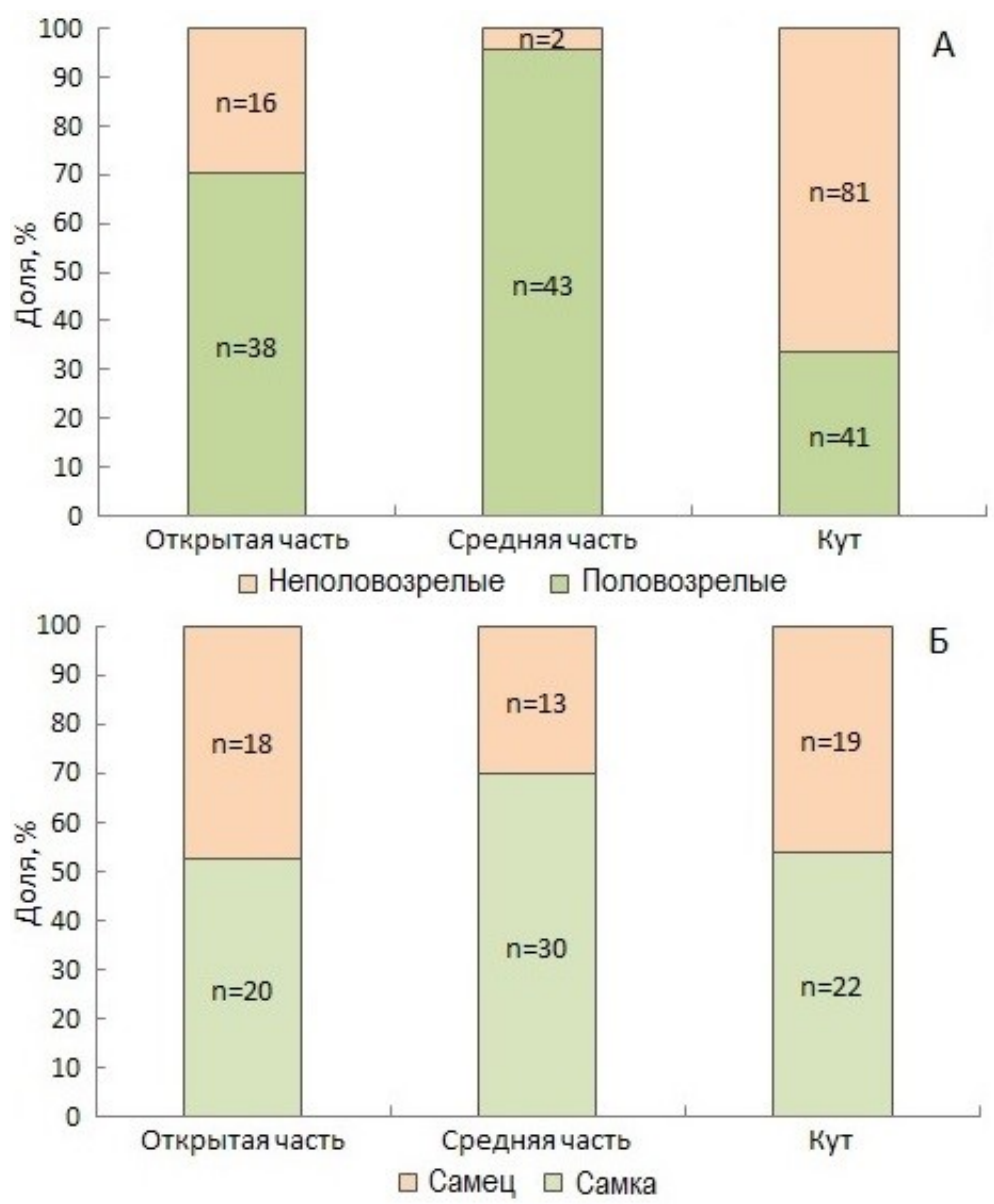

Рис. 5. Соотношение половозрелых и неполовозрелых особей (А), полов (Б) в поселениях Macoma calcarea в заливе Грён-фьорд

Fig. 5. The ratio of mature to immature individuals (A) and the sex ratio (Б) in Macoma calcarea aggregations in the Grenfjorden

Повсеместно отмечено преобладание самок над самцами, а соотношение полов близко к стандартному - 1:1, особенно в открытой и кутовой частях фьорда (рис. 5Б). В предыдущих наших исследованиях в южной и восточной частях Баренцева моря самцы доминировали над самками (Носкович, Павлова, 2018; Носкович, 2021).

Заключение. Анализ данных позволил выделить два поселения моллюсков Macoma calcarea в заливе Грён-фьорд. Первое поселение находится в открытой и средней частях залива, где глубина, температура и соленость были несколько выше, чем в куту. Здесь доминируют 
половозрелые особи со значительным количеством крупноразмерных моллюсков. Во втором поселении, в кутовой части залива, при меньшей глубине, температуре и солености численность поселения в 2.5-3 раза выше, чем в первом поселении, преобладает молодь. Следовательно, условия для размножения, питания и роста моллюсков более благоприятные. Размерный состав и соотношение половозрелых и неполовозрелых особей статистически различается во всех частях залива, а возрастной состав и скорость роста моллюсков практически одинаковы. Пока затруднительно объяснить именно такое распределение особей Macoma calcarea, для этого необходимо дальнейшее изучение их поселений в данном районе.

Работа выполнена по теме 9-19-01 “Донные сообщества Баренцева моря, его водосборного бассейна и сопредельных вод: экология, биоразнообразие, роль чужеродных видов" в рамках государственного задания (№ 0228-2019-0025).

\section{Литература}

Бритаев Т.А., Удалов А.А., Ржавский А.В. Структура и многолетняя динамика сообществ мягких грунтов заливов Баренцева моря // Успехи современной биологии. 2010. Т. 130, № 1. С. 50-62.

Золотарев В.Н. Склерохронология морских двустворчатых моллюсков. Киев: Наук. думка, 1989. 112 с.

Ивантер Э.В., Коросов А.В. Введение в количественную биологию: Учеб. пособие. Петрозаводск: Изд-во ПетрГУ, 2003. 304 с.

Лисицына К.Н., Герасимова А.В. Рост и распределение Macoma calcarea (Gmelin) в Карском море // Труды VII Международной научно-практической конференции "Морские исследования и образование (MARESEDU-2018)". T. III(IV). Тверь: ПолиПРЕСC, 2018. С. 418-424.

Матишов Г.Г. Дно океана в ледниковый период. Л.: Наука, 1984. 176 с.

Митяев М.В., Герасимова М.В. Фациальная изменчивость современных донных отложений в заливе Хорнсунн (Западный Шпицберген) // Комплексные исследования природы Шпицбергена. Вып. 3. Апатиты: Изд-во КНЦ РАН, 2003. C. 99-108.

Митяев М.В., Погодина И.А., Герасимова М.В. Фациальная изменчивость современных отложений залива Грён-фьорд, Западный Шпицберген // Комплексные исследования природы Шпицбергена. Вып. 5. Апатиты: Изд-во КНЦ РАН, 2005. C. $190-202$.

Meтоды изучения двустворчатых моллюсков / Под ред. Г.Л. Шкорбатова, Я.И. Старобогатова // Тр. Зоол. ин-та АН СССР. 1990. Т. 219. 208 с.

Наумов А.Д. Двустворчатые моллюски Белого моря. Опыт экологофаунистического анализа / Отв. ред. В.Я. Бергер. СПб.: Изд. Зоол. ин-та РАН, 2006. $367 \mathrm{c}$.

Носкович А.Э. Изменчивость скорости роста двустворчатого моллюска Macoma calcarea (Bivalvia, Tellinidae) в разных районах Баренцева моря // Современные эколого-биологические и химические исследования, техника и технология производств: Матер. Междунар. науч.-практ. конф. (г. Мурманск, 25 апреля 2018 г.). Мурманск: Изд-во Мурм. гос. техн. ун-та, 2018. С. 372-378. 
Носкович А.Э. Пространственное распределение, рост и размножение двустворчатого моллюска Macoma calcarea (Gmelin, 1791) у берегов Новой Земли // Биология моря. 2021. Т. 47, № 1. С. 45-53.

Носкович А.Э., Павлова Л.В. Особенности размножения двустворчатых моллюсков Macoma calcarea (Bivalvia, Tellinidae) в разных районах Баренцева моря // Исследования арктических экосистем: Матер. XXXVI конф. молодых ученых ММБИ КНЦ РАН, посвященной 40-летию научно-исследовательского судна “Дальние Зеленцы”. Мурманск: Изд. ММБИ КНЦ РАН, 2018. С. 77-84.

Результаты комплексных океанографических исследований залива Грёнфьорд (Западный Шпицберген) летом 2006 г. / М.В. Третьяков, О.Ф. Голованов, А.К. Павлов и др. // Комплексные исследования природы Шпицбергена. Вып. 7. Апатиты: Изд-во КНЦ РАН, 2007. С. 164-177.

Тарасов Г.А. Современное водно-ледниковое осадкообразование в заливе Грён-фьорд (Шпицберген) // Комплексные исследования природы архипелага Шпицберген. Вып. 9. М.: ГЕОС, 2009. С. 394-400.

Федяков В.В. Закономерности распределения моллюсков Белого моря. Л.: Изд-во Зоол. ин-та АН СССР, 1986. $125 \mathrm{c.}$

Филатова 3.А., Зенкевич Л.А. Количественное распределение донной фауны Карского моря // Тр. Всесоюз. гидробиол. общ-ва. 1957. Т. 8. С. 3-62.

Юргенс E.M. Экологическая характеристика моллюска Macoma balthica (Linne, 1758) в южной части Балтийского моря: Автореф. дис. ... канд. биол. наук. Калининград, 2006. 21 с.

Coe W.R. Sexual differentiation in mollusks. I. Pelecypods // Quart. Rev. Biol. 1943. Vol. 18, № 2. P. 154-164.

Distribution and growth of bivalve molluscs Serripes groenlandicus (Mohr) and Macoma calcarea (Gmelin) in the Pechora Sea / A.V. Gerasimova, N.A. Filippova, K.N. Lisitsyna et al. // Polar Biology. 2019. Vol. 42(9). P. 1685-1702.

Ockelmann W.K. The zoology of East Greenland: marine lamellibranchiate // Meddelelser om Grønland. 1958. Br. 122, № 4.256 p.

Oertzen J.-A. Cycles and rates of reproduction of six Baltic Sea bivalves of different zoogeographical origin // Marine Biology. 1972. Vol. 14. P. 143-149.

Petersen G.H. Life cycles and population dynamics of marine benthic bivalves from the Disco Bugt area of West Greenland // Ophelia. 1978. Vol. 17, № 1. P. 95-120.

Thorson $G$. The larval development, growth and metabolism of Arctic marine bottom invertebrates // Meddelelser om Grønland. 1936. Br. 100, № 6. 155 p.

DOI: 10.37614/2307-5252.2021.3.9.014

УДК $574.583(268.45)$

А.А. Олейник, О.В. Човган

Мурманский морской биологический институт РАН, г. Мурманск, Россия

\section{СОСТАВ И РАСПРЕДЕЛЕНИЕ МИКРОПЛАНКТОНА В БАРЕНЦЕВОМ МОРЕ В СВЯЗИ С ТЕРМОХАЛИННОЙ СТРУКТУРОЙ ПЕЛАГИАЛИ}

\section{Аннотация}

Представлены результаты исследований микропланктона в юго-западной части Баренцева моря, в области влияния Центральной ветви Нордкапского течения. Выявлены основные закономерности распределения отдельных видов и общих 
параметров обилия микропланктона в июне 2019 г. Для водных масс, отмеченных в районе исследований, описаны ключевые биологические параметры таксономический состав микропланктона, уровень общей биомассы и биомассы отдельных групп, характерные виды и комплексы видов.

Ключевые слова: Баренцево море, микропланктон, водные массы.

A.A. Oleynik, O.V. Chovgan

Murmansk Marine Biological Institute RAS, Murmansk, Russia

COMPOSITION AND DISTRIBUTION OF MICROPLANKTON IN THE BARENTS SEA IN CONNECTION WITH THE THERMOHALINE STRUCTURE OF THE PELAGIAL

\begin{abstract}
The research is devoted to the microplankton from the southwestern part of the Barents Sea, which is under the influence of the central branch of the North Cape Current. The main patterns of distribution for individual species and general parameters of microplankton abundance in June 2019 were revealed. The key biological parameters such as the taxonomic composition of microplankton, level of total biomass and biomass of individual groups, characteristic species and species complexes were described for the water masses of the investigated area during the study.
\end{abstract}

Keywords: Barents Sea, microplankton, water masses.

Введение. Особенности вертикальной стратификации планктонной биоты - значимый вопрос в исследовании морских экосистем. Одним из ключевых факторов, определяющих распределение планктона в водной толще, является термохалинная структура моря. Настоящая работа предлагает детальное изучение стратификации микропланктона Баренцева моря в летний период во взаимосвязи с параметрами температуры и солености.

Цель исследований - получить данные о летнем состоянии микропланктона открытой части Баренцева моря. Район работ выбирался таким образом, чтобы он был по возможности изолирован от влияния прибрежных вод. Этим критериям соответствует акватория над Демидовским желобом, в области прохождения Центральной ветви Нордкапского течения. Кроме значительной удаленности от берега данная область ограничивается с юга и севера струями Мурманского и Северной ветви Нордкапского течений соответственно.

Материал и методы. Материалом послужили планктонные пробы, отобранные 21 июня 2019 г. в юго-западной части Баренцевом моря на стандартном вековом разрезе “Кольский меридиан” (VI). В соответствии с целью исследований район работ был ограничен параллелями 73.5 и $75^{\circ}$ с. ш., где в течение одних суток выполнено 6 станций; расстояние между крайними станциями составило около 170 км (рис. 1). 


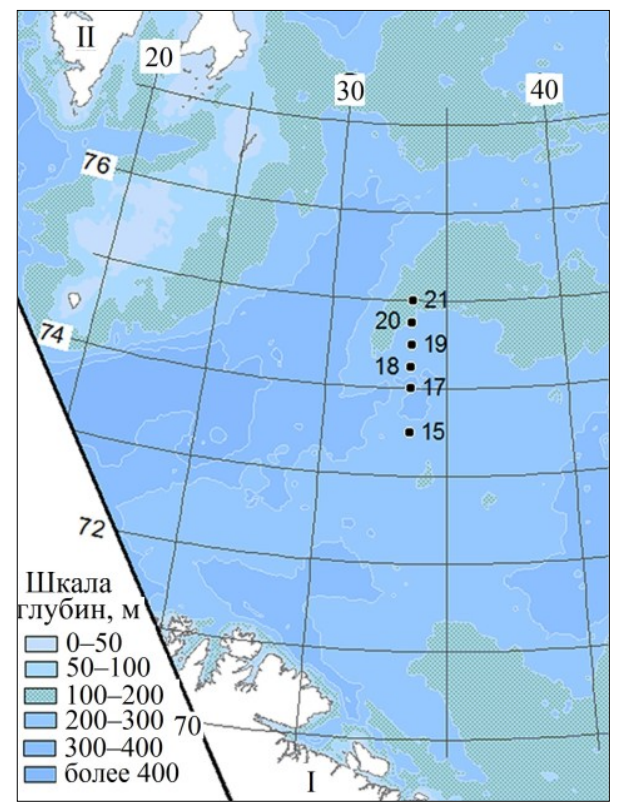

Рис. 1. Карта-схема расположения станций в районе исследований:

I - Кольский полуостров, II - архипелаг Шпицберген (Свальбард)

Fig. 1. Schematic map of the research area in the Barents Sea:

I - Kola Peninsula, II - Spitsbergen (Svalbard) archipelago

Горизонты отбора проб выбирались после предварительного вертикального профилирования с помощью зонда SBE 19plus V2 SeaCAT.

Для описания структуры водной толщи вычленяли области выраженных градиентов - скачков солености $(S)$ или температуры $(T)$. Эти структурные элементы выделяли путем низкочастотной фильтрации значений $S$ и $T$ : для соответствующей величины рассчитывался “скользящий” по вертикальному профилю градиент в 5-метровом слое с отсечением слоев мощностью менее 6 м. Граничные значения градиента температуры (по абсолютной величине) -0.01 и $0.05^{\circ} \mathrm{C} / \mathrm{M}$ (Бойцов, 2006). Слой с градиентом менее $0.01{ }^{\circ} \mathrm{C} / \mathrm{m}$ считали однородным, с градиентом $0.05{ }^{\circ} \mathrm{C} / \mathrm{M}$ и более - как хорошо выраженный (острый, термоклин), $0.01-0.04{ }^{\circ} \mathrm{C} / \mathrm{m}$ - как малоградиентный (или слабый термоклин). Соответствующие граничные значения солености -0.001 и $0.005 \mathrm{psu} / \mathrm{M}$. На вертикальных профилях, как правило, выделяется два слоя скачка у поверхности и у дна, они соответственно определены как верхний и нижний (придонный).

Батометрические пробы объемом около 1 л концентрировались способом обратной фильтрации через “ядерные” лавсановые фильтры с порами 0.95 мкм. Остаток с отфильтрованной взвесью сливался в пробирку и отстаивался, после чего было выполнено повторное концентрирование путем медленного сливания надосадочной жидкости 
через эластичную трубку с U-образно изогнутым капилляром на конце. Микроскопирование проводилось в проходящем свете при ув. 100-400 в счетной камере Нажотта.

Биомасса клеток была заимствована из опубликованных источников (Makarevich et al., 1991, 1993), в некоторых случаях выполнена оригинальная оценка биомассы клеток отдельных видов общепринятым способом (Кольцова, 1970), исходя из принятой плотности клеточного содержимого, равной 1. Всего проанализировано 64 пробы.

Мерой сходства микропланктона служило отношение числа общих видов для пары сравниваемых таксоценозов к среднему арифметическому числу видов в них (коэффициент Серенсена-Чекановского - K).

Результаты. В июне 2019 г. в микропланктонных сообществах в районе исследований отмечено 89 видов.

Bacillariophyta

Attheya longicornis Crawford et Gardner 1994

Chaetoceros atlanticus Cleve 1873

Chaetoceros borealis Bailey 1854

Chaetoceros concavicornis Mangin 1917

Chaetoceros contortus Schütt 1895

Chaetoceros debilis Cleve 1894

Chaetoceros decipiens Cleve 1873

Chaetoceros diadema (Ehrenberg) Gran 1897

Chaetoceros furcillatus Bailey 1856 (споры)

Chaetoceros laciniosus Schütt 1895

Chaetoceros mitra (Bailey) Cleve 1896

Chaetoceros socialis Lauder 1864 (споры)

Chaetoceros teres Cleve 1896

Cylindrotheca closterium (Ehrenberg) Reiman et Lewin 1964

Dactyliosolen fragilissimus (Bergon) Hasle 1991

Fragilariopsis oceanica (Cleve) Hasle 1965

Lennoxia faveolata Thomsen et Buck 1993

Leptocylindrus danicus Cleve 1889

Navicula distans W. Smith

Porosira glacialis (Grunow) Jörgensen 1905

Proboscia alata (Brightwell) Sundström 1986

Pseudo-nitzschia group delicatissima

Pseudo-nitzschia group seriata

Rhizosolenia hebetata Bailey 1856

Synedropsis hyperborea (Grunow) Hasle Medlin et Syvertsen 1994

Thalassionema nitzschioides (Grunow) Mereschkowsky 1902

Thalassiosira anguste-lineata (A. Schmidt) Fryxell et Hasle 1977

Thalassiosira bioculata (Grunow) Ostenfeld 1903

Thalassiosira gravida Cleve 1897 + Thalassiosira antarctica Comber 1896 
Thalassiosira nordenskioeldii Cleve 1873

Chrysophyta (включая Dictyochophyceae)

Dictyocha speculum Ehrenberg 1839

Dinobryon balticum (Schütt) Lemmerman 1900

Dinophyta

Alexandrium ostenfeldii (Paulsen) Balech et Tangen 1985

Amphidinium sphenoides Wulff 1916

Ceratium arcticum (Ehrenberg) Cleve 1901

Ceratium fusus (Ehrenberg) Dujardin 1841

Ceratium longipes (Bailey) Gran 1902

Ceratium strictum (Okamura et Nishikawa) Kofoid 1906

Dicroerisma psilonereiella Taylor et Cattell 1969

Dinophysis acuminata Claparède et Lachmann 1859

Dinophysis norvegica Claparède et Lachmann 1859

Dinophysis rotundata Claparède et Lachmann 1859

Gonyaulax spinifera (Claparéde et Lachmann) Diesing 1865

Gyrodinium lachryma (Meunier) Kofoid et Swezy 1921 + Gyrodinium

fusiforme Koifoid et Swezy 1921

Gyrodinium nasutum (Wulff) Schiller 1933

Lessardia aff. elongata Saldarriaga et F.J.R. Taylor 2003

Micracanthodinium claytonii (Holmes) Dodge 1982

Micracanthodinium setiferum (Lohmann) Deflandre 1937

Oxytoxum caudatum Schiller 1937

Pentapharsodinium dalei Indelicato et Loblich 1986

Preperidinium meunierii (Pavillard) Elbrachter 1993

Pronoctiluca pelagica Fabre-Domerque 1889

Prorocentrum balticum (Lohmann) Loeblich III 1970

Protoceratium reticulatum (Claparède et Lachmann) Bütschli 1885

Protoperidinium arcticum (Grøntved et Seidenfaden) Okolodkov 1997

Protoperidinium bipes (Paulsen) Balech 1974

Protoperidinium brevipes (Paulsen) Balech 1974

Protoperidinium conicoides (Paulsen) Balech 1974

Protoperidinium decipiens Parke et Dodge 1976

Protoperidinium denticulatum (Gran et Braarud) Balech 1974

Protoperidinium depressum (Bailey) Balech 1974

Protoperidinium islandicum (Paulsen) Balech 1973

Protoperidinium laticeps (Grøntved et Seidenfaden, 1938) Balech 1974

Protoperidinium monacanthum (Broch) Balech 1973

Protoperidinium ovatum Pouchet 1883

Protoperidinium pallidum (Ostenfeld) Balech 1973

Protoperidinium pellucidum Bergh 1881

Protoperidinium pyriforme (Paulsen) Balech 1974

Protoperidinium saltans (Meunier) Balech 1973

Protoperidinium thulesense (Balech) Balech 1973 
Torodinium robustum Kofoid et Swezy 1921

Haptophyta

Coccolithus pelagicus (Wallich) Schiller 1930

Phaeocystis pouchetii (Hariot) Lagerheim 1896

Prasinophyta

Halosphaera viridis Schmitz 1878

Fusopsis elongata Meunier 1910, форма incertae sedis

Ciliophora

Acanthostomella norvegica (Daday, 1887)

Coxliella aff. pseudannulata (Jörgensen, 1899)

Didinium gargantua Meunier, 1910

Laboea strobila Lohmann, 1908

Leprotintinnus pellucidus (Cleve, 1899)

Mesodinium rubrum (Lohmann, 1908)

Parafavella denticulata (Ehrenberg, 1840)

Ptychocylis obtusa Brandt, 1906

Salpingella acuminata (Claparède et Lachmann, 1858)

Strombidium aff. conicum (Lohmann, 1908)

Tintinnopsis urnula Meunier, 1910

Radiozoa

Amphimelissa setosa (Cleve, 1899)

Pseudodictyophimus gracilipes (Bailey) Petrushevskaya, 1971

Rotifera

Synchaeta triophthalma Lauterborn, 1894

Рассмотрим характеристики водных масс и микропланктона по станциям.

Станция 15 (рис. 2А,Б,В). Термохалинная структура пелагиали: верхний перемешанный (квазиоднородный) слой - 0-30 м, верхний слой скачка - 31-50 м, подповерхностный слой - 51-224 м, нижний слой скачка - 225-249 м, придонный слой - 250-272 м.

Для верхнего квазиоднородного слоя характерна максимальная на станции температура воды - около $4.4{ }^{\circ} \mathrm{C}$. Верхний слой скачка представляет собой гомохалинный слабо выраженный термоклин $\left(\mathrm{GradT}=-0.04{ }^{\circ} \mathrm{C} / \mathrm{M}\right)$, подповерхностный слой - гомохалинный малоградиентный термоклин $\left(\mathrm{GradT}=-0.01{ }^{\circ} \mathrm{C} / \mathrm{M}\right)$. Нижний слой скачка это хорошо выраженный термоклин $\left(\mathrm{GradT}=-0.05{ }^{\circ} \mathrm{C} / \mathrm{M}\right)$, в верхней части которого (225-240 м) отмечается снижение солености с 34.95 до $34.87 \mathrm{psu}$ (GradS $=-0.005 \mathrm{psu} / \mathrm{M})$, а в нижней - повышение солености до $34.94 \mathrm{psu}$ $(\mathrm{GradS}=0.008 \mathrm{psu} / \mathrm{M})$. Область слабого клинального снижения температуры с 0.50 до $0.43{ }^{\circ} \mathrm{C}$ и солености с 34.945 до 34.935 psu характерна для придонного слоя. В принятых границах градиенты соответствуют условиям гомохалинности и гомотермии. 
Распределение микропланктона на станции (9 проб) исследовалось по всему вертикальному профилю. Отмечено 75 таксонов видового ранга.

Вертикальное распределение обилия микропланктона характеризуется пиком биомассы в верхнем слое пелагиали (рис. 2В) и резким падением на горизонтах 50, 60 и 100 м - соответственно, $370 \cdot 10^{-3}, 63 \cdot 10^{-3}$ и $3 \cdot 10^{-3}$ мг/л. Средняя биомасса микропланктона в слое 100-200 м варьирует от $3 \cdot 10^{-3}$ до $4 \cdot 10^{-3}$ мг/л, на придонном горизонте 275 м составляет $5 \cdot 10^{-3} \mathrm{Mг} /$ л.

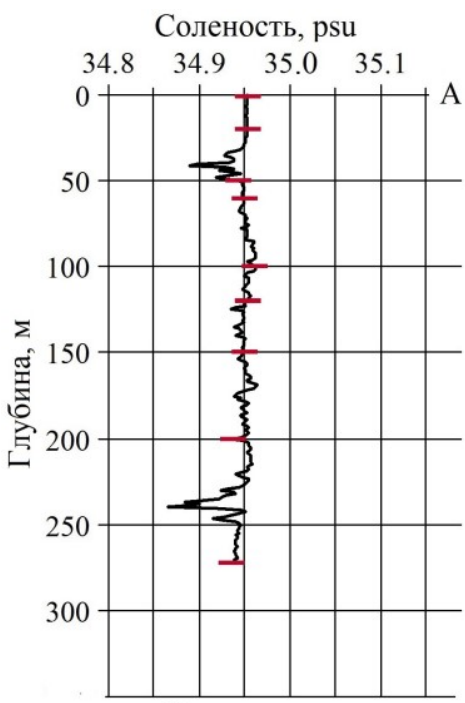

Соленость, psu

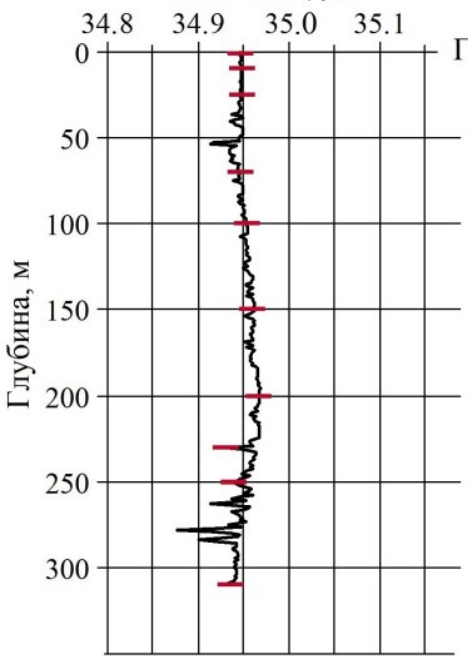

Температура, ${ }^{\circ} \mathrm{C}$

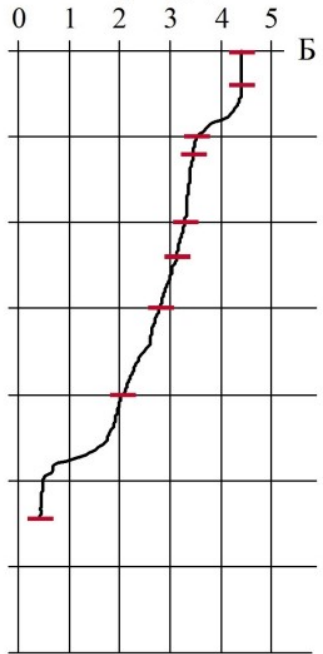

Температура, ${ }^{\circ} \mathrm{C}$ $\begin{array}{llllll}0 & 1 & 2 & 3 & 4 & 5\end{array}$

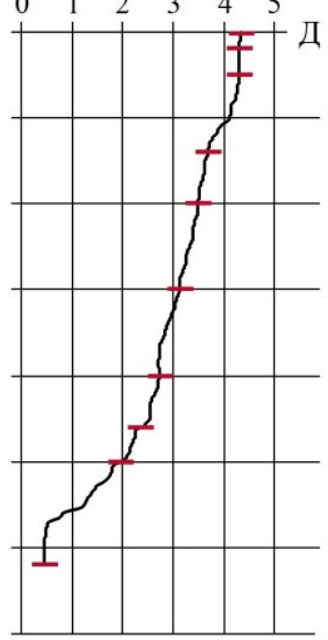

Биомасса, мг/л

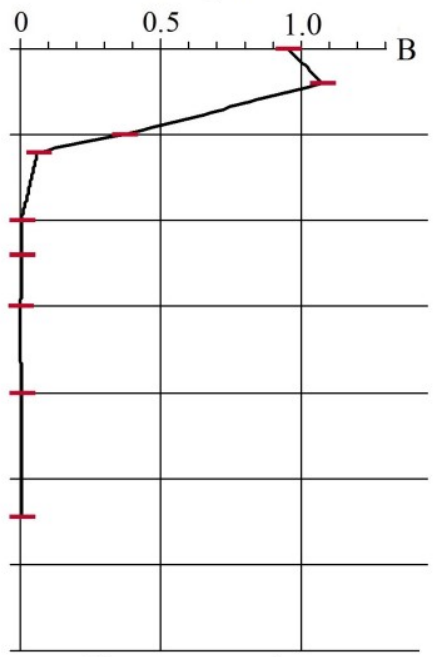

Биомасса, мг/л

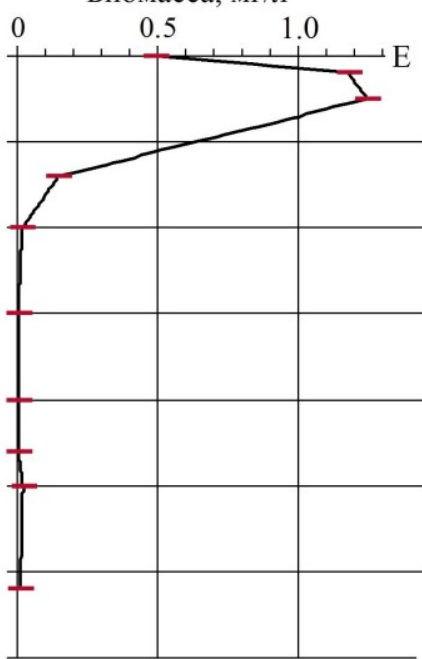

Рис. 2. Вертикальное распределение температуры воды, солености и общей биомассы микропланктона на станциях 15 (А, Б, В) и 17 (Г, Д, Е). Красными метками отмечены горизонты, где исследован микропланктон

Fig. 2. Vertical distribution of the water temperature, salinity and total biomass of microplankton at the stations 15 (A, Б, B) and 17 (Г, Д, E). Red marks are noted horizons of microplankton research 
Численность по всему профилю более чем на 90 \% обеспечена диатомеями. На уровне отдельных таксонов доминируют Chaetoceros concavicornis и Attheya longicornis (по 17 \% общей численности микропланктона) - на горизонтах 0 и 20 м, мелкие Chaetoceros spp. в слое 0-60 м, гипноспоры Chaetoceros socialis, Chaetoceros debilis и Chaetoceros diadema - в слое 50-275 м.

Анализ таксономического сходства показал, что в пелагиали можно выделить два комплекса видов - в слое 0-50 и 100-200 м. Сходство между ними сравнительно высокое $(K \approx 0.6$ против $K=0.7-0.8$ внутри каждого из комплексов); таксоцен, локализованный в верхних горизонтах пелагиали $(0,20,50$ м), выделяется большой долей (около 1/3) видов, не отмеченных ниже по профилю (здесь и далее - “специфические"). Таксоценоз, отмеченный на глубине 60 м, определяется как смешанный, в равной степени близкий $(K \approx 0.6)$ к обоим выделенным комплексам.

Обилие микропланктона на горизонтах 0 и 20 м примерно в равной степени определяют динофлагелляты и диатомеи - 50 и $40 \%$ общей биомассы соответственно. На видовом уровне из диатомовых преобладают Chaetoceros concavicornis и Chaetoceros diadema (по 30 \% биомассы диатомей соответственно), из динофлагеллят - Gyrodinium lachrymalfusiforme и Protoperidinium depressum (50 и $15 \%$ биомассы динофлагеллят соответственно), из цилиат - Laboea strobila и Mesodinium rubrum (40 и $20 \%$ биомассы инфузорий).

На глубине 50 и 60 м доминируют диатомовые (около $95 \%$ общей биомассы), на видовом уровне - Chaetoceros diadema (в основном клетки с гипноспорами, 55 \% биомассы диатомей) и мелкий Chaetoceros spp. (около 15 \%). Из динофлагеллят около 55 \% биомассы приходится на Gyrodinium lachrymalfusiforme и Protoperidinium depressum.

Общая биомасса на $50 \%$ сформирована диатомовыми микроводорослями на глубине 100, 120, 150 и 200 м, при этом около 60 \% биомассы диатомей приходится на гипноспоры Chaetoceros diadema и Chaetoceros debilis.

Ведущую роль в формировании общей биомассы микропланктона играют диатомовые микроводоросли (около 70 \%) и на глубине 275 м. Из видов доминируют Chaetoceros concavicornis, Chaetoceros diadema и Thalassiosira gravida/antarctica, каждый их которых обеспечивает примерно по 20 \% биомассы диатомей, и Protoperidinium depressum (50\% биомассы динофлагеллят и примерно $10 \%$ общей биомассы микропланктона).

Станция 17 (рис. 2Г,Д,Е). Термохалинная структура пелагиали: верхний перемешанный (квазиоднородный) слой - 0-49 м, верхний слой скачка - 50-61 м, подповерхностный слой - 62-225 м, нижний слой скачка - 226-287 м, придонный слой - 288-310 м.

Гомохалинный, практически гомотермичный $\left(\operatorname{GradT}=-0.004{ }^{\circ} \mathrm{C} / \mathrm{M}\right)$ квазиоднородный слой характеризуется максимальной на станции температурой $-4.3-4.1^{\circ} \mathrm{C}$. Верхний слой скачка имеет слабо выраженный 
термоклин $\left(\mathrm{GradT}=-0.03{ }^{\circ} \mathrm{C} / \mathrm{M}\right)$, небольшое клинальное уменьшение солености (в целом по слою от 34.945 до $34.935 \mathrm{psu}, \mathrm{GradS}=-0.0007 \mathrm{psu} / \mathrm{M}$ ) и локальный минимум на глубине 53-54 м (34.915 psu). Гомохалинному и практически гомотермичному ( $\left.\operatorname{GradT}=-0.008^{\circ} \mathrm{C} / \mathrm{M}\right)$ подповерхностному слою свойственно общее снижение температуры от 3.8 до $2.5^{\circ} \mathrm{C}$ и рост солености от 34.94 до 34.96 psu в направлении дна. В нижней части слоя на глубине 190-220 м отмечены максимальные на станции значения солености - до 34.968 psu. Придонный слой скачка - гомохалинный слабо выраженный термоклин $\left(\operatorname{GradT}=-0.03{ }^{\circ} \mathrm{C} / \mathrm{M}\right)$, в пределах которого отмечается снижение температуры от 2.5 до $0.5^{\circ} \mathrm{C}$ и солености от 34.96 до 34.94 psu. В нем выделяется остроградиентная зона (ось термоклина, 275-281 м, GradT $\left.=-0.07{ }^{\circ} \mathrm{C} / \mathrm{m}\right)$, включающая локальные минимумы солености - около 34.90-34.91 psu. Область слабого клинального снижения температуры от 0.52 до $0.45{ }^{\circ} \mathrm{C}$ и солености от 34.942 до $34.935 \mathrm{psu}-$ придонный слой. В принятых границах градиенты соответствуют условиям гомохалинности и гомотермии.

На станции было взято 10 проб, распределение микропланктона на ней рассмотрено по всему вертикальному профилю. Отмечено 67 таксонов видового ранга.

Вертикальное распределение микропланктона характеризуется подповерхностным пиком биомассы на горизонтах 10 и 25 м и резким снижением на 70,100 и 150 м $-150 \cdot 10^{-3}, 20 \cdot 10^{-3}$ и $4 \cdot 10^{-3}$ мг/л соответственно (рис. 2Е).

Доля диатомовых водорослей в суммарной численности микропланктона составляет до $97 \%$, при этом в слое 0-70 м на долю Chaetoceros diadema приходится около $30 \%$, еще примерно по $10 \%$ на Chaetoceros debilis, Chaetoceros laciniosus и Attheya longicornis. На глубине 100 м и ниже около $20 \%$ общей численности диатомей обеспечивает Chaetoceros diadema, около 60 \% - гипноспоры Chaetoceros socialis.

Анализ таксономического сходства показал, что можно уверенно выделить только один комплексов видов, отмеченный на горизонтах 0 , $10,25,70$ м. Таксоценозы других горизонтов представляют собой в той или иной степени обедненные варианты этого единственного комплекса и различаются между собой наличием или отсутствием единичных видов.

В структуре биомассы в слое 0-25 м ведущая роль принадлежит в равной мере диатомеям и динофлагеллятам - 40 \% общей биомассы микропланктона, на уровне вида доминируют Chaetoceros concavicornis и Chaetoceros diadema (соответственно, 12 и 45 \% биомассы диатомей) и Gyrodinium lachrymalfusiforme и Protoperidinium depressum (соответственно, 45 и $15 \%$ биомассы динофлагеллят).

В слое 70-250 м преобладают диатомовые (примерно 60 \% общей биомассы), из которых доминирует Chaetoceros diadema (50 \% биомассы диатомей): в слое 70-150 м - в основном споронесущие клетки, на глубине 230 и 250 м - преимущественно вегетативные. 
На глубине 310 м (у дна) около 50 \% общей биомассы микропланктона приходится на инфузорий, примерно $30 \%$ на диатомей. Chaetoceros diadema формирует 77 \% биомассы диатомей, у инфузорий около 90 \% биомассы приходится на Strombidium spp.

Станция 18 (рис. 3А,Б,В). Термохалинная структура пелагиали: верхний перемешанный (квазиоднородный) слой - 0-6 м, верхний слой скачка - 7-27 м, подповерхностный слой - 25-165 м, нижний слой скачка 166-226 м, придонный слой - 227-304 м.

Квазиоднородный слой характеризуется максимальной для станции температурой $-3.84-3.82{ }^{\circ} \mathrm{C}$. Верхний слой скачка - это хорошо выраженный термо- и галоклин; значения температуры и солености с глубиной снижаются, градиенты соответствующих величин $-\mathrm{GradT}=-0.06{ }^{\circ} \mathrm{C} / \mathrm{M}$ и $\mathrm{GradS}=-0.002 \mathrm{psu} / \mathrm{M}$. Подповерхностный слой представляет собой малоградиентный термоклин $\left(\mathrm{GradT}=-0.01{ }^{\circ} \mathrm{C} / \mathrm{m}\right)$ с максимальными для станции значениями солености - до 34.95-34.96 psu в слое 90-150 м. Придонный слой скачка - малоградиентный термо- и галоклин $\left(\operatorname{GradT}=-0.03{ }^{\circ} \mathrm{C} / \mathrm{M}, \mathrm{GradS} \approx 0.0005 \mathrm{psu} / \mathrm{M}\right)$, максимальные градиенты отмечены в слое 168-190 м (ось придонного термо- и галоклина) $\operatorname{GradT}=-0.04{ }^{\circ} \mathrm{C} / \mathrm{M}, \mathrm{GradS}=0.001 \mathrm{psu} / \mathrm{M}$. Придонный слой практически изотермичен $\left(\mathrm{GradT}=-0.004{ }^{\circ} \mathrm{C} / \mathrm{M}\right)$, температура с глубиной снижается от $-0.2{ }^{\circ} \mathrm{C}(227$ м $)$ до $-0.5{ }^{\circ} \mathrm{C}(304$ м $)$ - минимальные для станции значения. Значения солености в слое колеблются около 34.925 psu.

На станции исследовали распределение микропланктона в области слоя верхнего скачка. Для этого в слое 0-110 м взято 12 проб с “шагом” в 10 м. Всего отмечено 50 таксонов видового ранга.

Общая численность микропланктона составила около 60 тыс. кл/л в слое 0-20 м, 5 тыс. кл/л в слое 30-80 м и 0.2 тыс. кл/л в слое 90-110 м. Основу численности микропланктона по всему исследованному профилю составили диатомовые микроводоросли, в среднем более $60 \%$ общего числа клеток. На уровне таксонов видового ранга наибольшая плотность отмечена у Phaeocystis pouchetii - 25 \% общей численности, Chaetoceros concavicornis - $15 \%$. При этом Thalassiosira gravida/antarctica обеспечила $25 \%$ численности в слое $30-80$ м.

Распределение микропланктона в слое 0-110 м характеризуется снижением параметров обилия (биомассы и численности) с ростом глубины (рис. 3В). Можно выделить два скачка обилия в слоях 10-30 и 60-90 м. Так общая биомасса микропланктона в слое 10-30 м снизилась с 1.0 до $0.08 \mathrm{мг/л,} \mathrm{в} \mathrm{слое} 60-90 \mathrm{M}-$ с $80 \cdot 10^{-3}$ до $1 \cdot 10^{-3}$ мг/л, а общая численность примерно от 100 до 6 тыс. кл/л и от 7.0 до 0.4 тыс. кл/л соответственно.

Таксономический анализ показал, что состав микропланктона верхних горизонтов $(0,10$ и 20 м) однороден в высокой степени $(K \approx 0.8)$, всего на трех горизонтах отмечено 44 таксона видового ранга, из которых 15 форм ниже по профилю не встречены. 


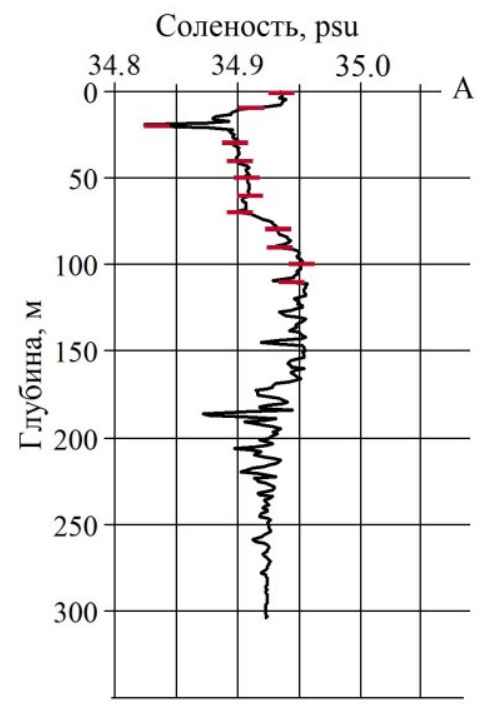

Соленость, psu

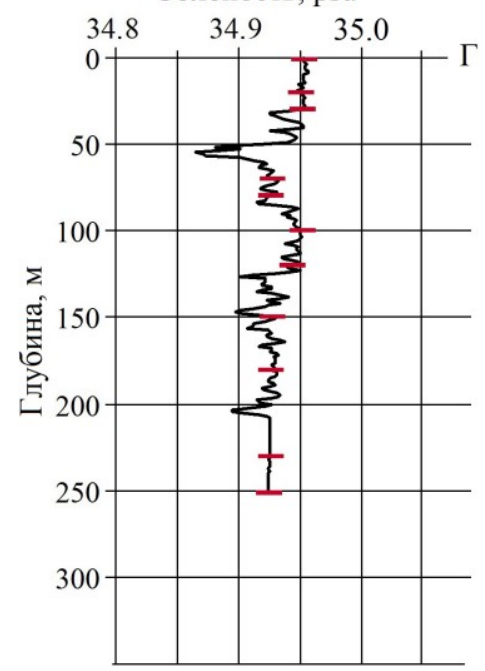

Температура, ${ }^{\circ} \mathrm{C}$

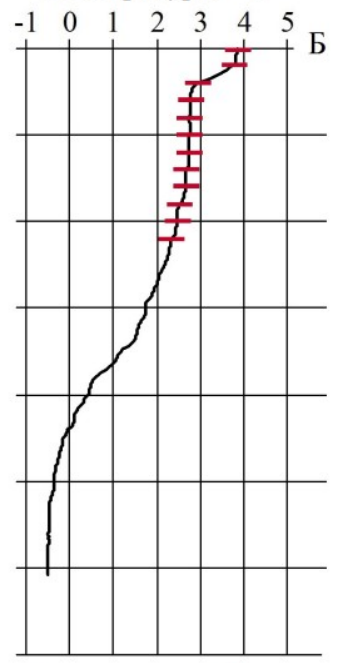

Температура, ${ }^{\circ} \mathrm{C}$

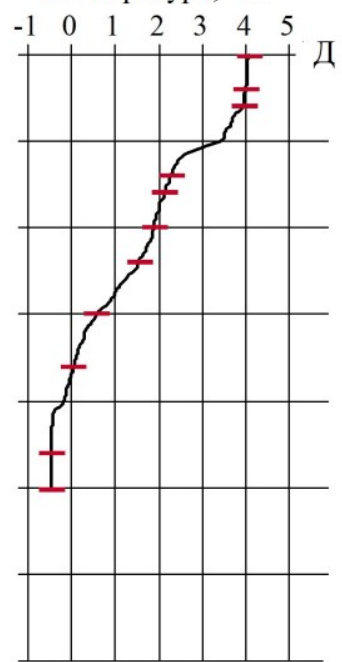

Биомасса, мг/л

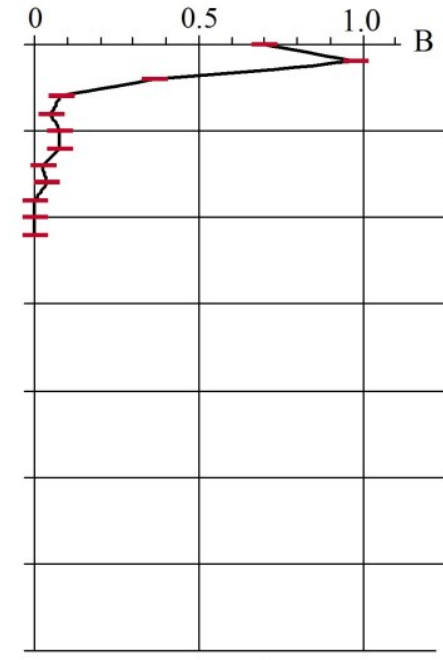

Биомасса, мг/л

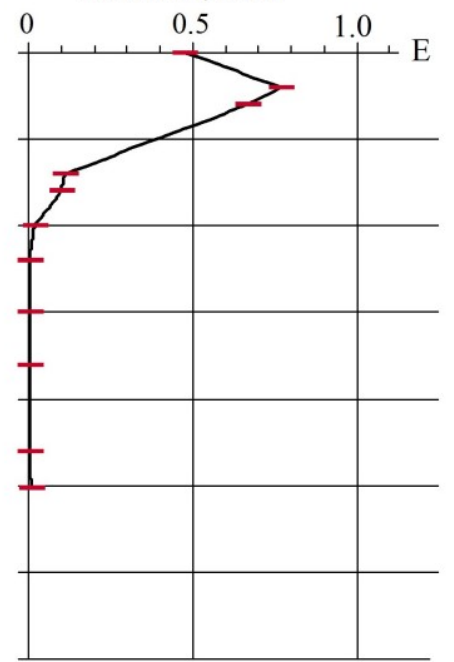

Рис. 3. Вертикальное распределение температуры, солености и общей биомассы микропланктона на станциях 18 (А, Б, В) и 19 (Г, Д, Е). Красными метками отмечены горизонты, исследованные на микропланктон

Fig. 3. Vertical distribution of the water temperature, salinity and total biomass of microplankton at the stations 18 (А, Б, В) and 19 (Г, Д, Е). Red marks are noted horizons of microplankton research

На уровне таксонов высшего ранга доминируют Dinophyta - около 70 \% общей биомассы микропланктона, примерно по 15 \% приходится на Bacillariophyta и Infusoria. На уровне вида в структуре биомассы на всех трех горизонтах ведущая роль принадлежит одним и тем же таксонам. Так из диатомовых - это Chaetoceros concavicornis, Thalassiosira gravidalantarctica, Thalassiosira nordenskioeldii - суммарно около $75 \%$ биомассы диатомей, из динофлагеллят - Gyrodinium lachrymalfusiforme и 
Protoperidinium depressum - около 40 и 20 \% биомассы динофлагеллят соответственно, из инфузорий - хлорофиллсодержащая Laboea strobila и Strombidium aff. conicum - 40 и 20 \% биомассы инфузорий соответственно.

Микропланктон на глубине 30, 40, 50, 60 и 70 м представляет собой таксономически обедненный комплекс верхнего слоя, с которым у него 28 общих таксонов видового ранга из 34; 5 таксонов отмечено только на этих горизонтах. На уровне таксонов высшего ранга в структуре биомассы доминируют Dinophyta - около 55 \% общей биомассы микропланктона, примерно 30 \% приходится на Bacillariophyta и $15 \%$ - на Infusoria. На видовом уровне доминируют Thalassiosira gravida/antarctica (примерно 70 \% биомассы диатомей), Gyrodinium lachrymalfusiforme и Protoperidinium depressum (30 и $20 \%$ биомассы динофлагеллят соответственно), из инфузорий - тинтиннида Ptychocylis obtusa (около 45 \% биомассы инфузорий).

Ниже горизонта 70 м отмечено существенное падение числа таксонов видового ранга. Так если на 70 м зарегистрировано 16 таксонов, то на 80 м - 8, на 90 м - 4, на 110 м - 2 таксона. На глубине 100 м представители микропланктона не обнаружены. Всего в слое 80-110 м отмечено 13 видов. По таксономическому составу микропланктон в слое 80-110 м представляет собой сильно обедненный комплекс верхнего слоя, с которым у него 12 общих видов. В структуре биомассы на горизонте 80 м доминируют Thalassiosira gravida/antarctica и Protoperidinium depressum, т. е. по этому показателю наблюдается сходство с верхними слоями пелагиали; на горизонтах 90 м и ниже структуру доминирования определить корректно невозможно из-за низкой плотности клеток.

Станция 19 (рис. 3Г,Д,Е). Термохалинная структура пелагиали: верхний перемешанный слой - 0-28 м, верхний слой скачка - 29-63 м, подповерхностный слой - 64-196 м, нижний слой скачка - 197-207 м, придонный слой - 208-251 м.

Верхний квазиоднородный слой представляет собой гомохалинный, практически гомотермичный $\left(\mathrm{GradT}=-0.004{ }^{\circ} \mathrm{C} / \mathrm{M}\right)$ слой с максимальными на станции значениями температуры воды - около $4.0^{\circ} \mathrm{C}$ и солености примерно 34.955 psu. Верхний слой скачка имеет хорошо выраженный термоклин $\left(\operatorname{GradT}=-0.05{ }^{\circ} \mathrm{C} / \mathrm{M}\right)$ с незначительным в целом по слою уменьшением солености от 34.95 до $34.92 \mathrm{psu}(\mathrm{GradS}=-0.001 \mathrm{psu} / \mathrm{M}$ ) и локальным минимумом на глубине 51-58 м - около $34.88 \mathrm{psu}$. Подповерхностный слой в целом - это гомохалинный (34.92-34.93 psu) малоградиентный термоклин $\left(\operatorname{GradT}=-0.02{ }^{\circ} \mathrm{C} / \mathrm{M}\right)$, в котором выделяется локальный максимум солености (34.95 psu) примерно в слое 90-120 м, ограниченном маломощными (7-8 м) слоями с галоклином противоположных знаков (сверху GradS $=0.003 \mathrm{psu} /$ м, снизу GradS $=-0.003 \mathrm{psu} / \mathrm{m}$ ). Придонный слой скачка представляет собой слабо выраженный термоклин 
$\left(\operatorname{GradT}=-0.03{ }^{\circ} \mathrm{C} / \mathrm{M}\right)$, в пределах которого отмечается локальный минимум солености - 34.90 psu. Гомохалинный и гомотермичный придонный слой характеризуется минимальными на станции значениями температуры - примерно $-0.45^{\circ} \mathrm{C}$.

Распределение микропланктона изучено по всему вертикальному профилю станции (11 проб). Отмечено 78 таксонов видового ранга.

Вертикальное распределение микропланктона характеризуется пиком биомассы в верхнем слое пелагиали (рис. 3Е) и резким падением обилия на горизонтах 30, 70(80), 100 и 120 м $-670 \cdot 10^{-3}, 110(100) \cdot 10^{-3}, 20 \cdot 10^{-3}$ и $3 \cdot 10^{-3}$ мг/л соответственно. Биомасса микропланктона в слое $120-230 \mathrm{м}$ варьирует от $3 \cdot 10^{-3}$ до $6 \cdot 10^{-3}$ мг/л, на глубине 255 м составляет $9 \cdot 10^{-3}$ мг/л.

Основная доля численности по всему профилю на $90 \%$ формируется диатомеями, из которых в слое 0-80 м более половины общей численности микропланктона приходится суммарно на Chaetoceros concavicornis, Chaetoceros diadema и Attheya longicornis, на глубине 100 м и ниже около 60 \% общей численности диатомей принадлежит гипноспорам Chaetoceros socialis.

Анализ таксономического сходства показал, что в пелагиали можно выделить два комплекса видов - на горизонтах 0, 20, 30, 70, 80 и 100, 120, $150,180,230,255$ м. Общее количество видов в первом комплексе 65, из них 33 присутствуют на всех горизонтах слоя, а во втором - 13 видов из 45 зарегистрированных на всех горизонтах слоя.

Обилие микропланктона на горизонтах 0,20 и 30 м примерно в равной степени определяют динофлагелляты и диатомеи (соответственно 45 и $50 \%$ общей биомассы). На уровне вида доминируют диатомовые Chaetoceros concavicornis и Chaetoceros diadema (по $30 \%$ биомассы диатомей) и Leptocylindrus danicus (примерно 10 \%), динофлагелляты Gyrodinium lachrymalfusiforme и Protoperidinium depressum (35 и $20 \%$ биомассы динофлагеллят соответственно), из цилиат - Mesodinium rubrum (около $40 \%$ биомассы инфузорий).

Глубже 30 м по профилю доминируют диатомовые, составляющие $95 \%$ общей биомассы на горизонтах 70 и 80 м, и около $60 \%$ на горизонтах 100, 120, 150 и 180 м. Из видов доминируют Chaetoceros diadema (в основном гипноспоры) и Chaetoceros concavicornis (по $15 \%$ биомассы диатомей на горизонтах 70 и 80 м), 75 \% биомассы диатомей пришлось на неидентифицированные до вида таксоны.

На горизонтах 230 и 255 м четко выраженного доминирования не наблюдается; можно отметить единственный вид динофлагеллят Amphidinium sphenoides, формирующий сравнительно высокую долю обилия микропланктона на этих горизонтах (около 50 \% биомассы динофлагеллят и 20 \% общей биомассы).

Станция 20 (рис. 4А,Б,В). Термохалинная структура пелагиали: верхний перемешанный (квазиоднородный) слой - 0-22 м, верхний слой скачка - 23-60 м, подповерхностный слой - 61-147 м, придонный слой $148-225 \mathrm{M}$. 
Верхний квазиоднородный слой характеризуется сравнительно высокой для станции температурой воды - 2.0-2.1 ${ }^{\circ} \mathrm{C}$ и минимальной соленостью - 34.72-34.74 psu. В нижней части этого слоя отмечена тенденция к росту солености с глубиной, которая отчетливо проявляется в верхней части слоя скачка формированием острого галоклина на глубине 23-33 м (GradS = $0.007 \mathrm{psu} / \mathrm{M})$. В нижней части верхнего слоя скачка градиент солености несколько уменьшается в абсолютном выражении - GradS $=0.003 \mathrm{psu} / \mathrm{M}$. Температура в верхней части слоя скачка с глубиной растет, формируется слабо выраженный термоклин $\left(\operatorname{GradT}=0.03{ }^{\circ} \mathrm{C} / \mathrm{M}\right)$; в нижней части слоя скачка (34-60 м) образуется термоклин с градиентом обратного знака $\left(\operatorname{GradT}=-0.06{ }^{\circ} \mathrm{C} / \mathrm{M}\right)$, т. е. температура с глубиной быстро снижается. Подповерхностный слой представляет собой малоградиентный термо- и галоклин $\left(\mathrm{GradT}=-0.01{ }^{\circ} \mathrm{C} / \mathrm{M}\right.$ и $\mathrm{GradS} \approx 0.0005 \mathrm{psu} / \mathrm{M})$ и непосредственно подстилается гомохалинным и гомотермичным придонным слоем, с минимальными на станции значениями температуры $\left(-0.59^{\circ} \mathrm{C}\right)$. Нижний слой скачка отсутствует.

На станции изучено распределение микропланктона в области верхнего слоя скачка. Обработано 12 проб, взятых в слое 0-110 м с “шагом" в 10 м. Всего отмечен 41 таксон видового ранга.

Общая численность микропланктона в слое 0-40 м определяется Dinobryon balticum из отдела Chrysophyta (25-30\% общей численности) и диатомовой Chaetoceros concavicornis (20-30 \% общей численности). Ниже, в слое 50-110 м, численность определяется развитием гаптонемовой микроводоросли Phaeocystis pouchetii. На глубине 50 м ее доля в общей численности составила более 50 \%, ниже по профилю свыше $90 \%$. Максимальное развитие этого вида отмечено на горизонтах 60, 70 и 80 м - 62, 193 и 64 тыс. кл/л соответственно. На глубине 50 м также велика доля Thalassiosira gravida/antarctica - 35 \% общей численности.

Распределение микропланктона характеризуется на глубине 20 м подповерхностным пиком биомассы (рис. 4В), формируемым на $50 \%$ Protoperidinium depressum, и на глубине 50 м - Thalassiosira gravida/antarctica, которая обеспечивает 60 \% биомассы. Ниже 80 м наблюдается резкое снижение обилия микропланктона.

Таксономический анализ показал, что состав микропланктона изменяется по вертикали таким образом, что общность таксоценов закономерно снижается по мере роста глубины; общность таксоценов соседних горизонтов находится на уровне $K=0.6-0.7$. Исключение горизонты 20 и 30 м, характеризующиеся наибольшим сходством $(K=0.8)$ и самым большим числом видов (22 и 23$)$ в микропланктоне. Его таксономически обедненный вариант отмечен на верхних горизонтах (0 и 10 м - 17 и 19 видов соответственно). Всего на горизонтах 0, 10, 20 и 30 м отмечено 10 видов, которые на других горизонтах не выявлены. Ниже по профилю, на горизонтах 40, 50 и 60 м, отмечено закономерное снижение числа видов - 21, 15 и 13 соответственно, при этом появляется 
4 “специфических" вида и исчезает из состава 12 видов. На этом основании мы выделили два таксономических комплекса - 0-30 и 40-60 м, хотя формальное сходство между ними высокое $(K=0.7)$.

С ростом глубины продолжается уменьшение числа видов в таксоцене: 70 м - 8 видов, 80-110 м - от 5 до 3 видов. При таком малом числе видов таксоценозы на этих горизонтах имеют низкое сходство с прочими, при этом высокий индекс общности между собой $(K=0.66$ для горизонтов 70 и 80 м, $K=0.75$ для 90 и 100 м). Соответственно, формально выделяется еще два таксоцена - на горизонтах 70, 80 и 90, 100 м. При этом общих “специфических" видов в этих таксоценах нет, поэтому в равной мере (если не принимать во внимание крайне малое число идентифицированных видов) их можно включить в состав таксоцена из слоя 40-60 м.

На глубине 110 м, учитывая коэффициент Серенсена-Чекановского, микропланктон получает обособленное положение (сходство с любым из прочих горизонтов менее 0.3), при этом из 4 зарегистрированных здесь таксонов видового ранга 1 отсутствует на других горизонтах, 2 - общие с верхними слоями 0-30 и 40-60 м. Phaeocystis pouchetii- единственный вид, общий для всех описанных выше комплексов и горизонтов.

В структуре биомассы на горизонтах 0,1020 и 30 м ведущая роль принадлежит динофлагеллятам (более 80 \% от биомассы микропланктона в слое 0-20 м, $50 \%$ - на горизонте 30 м), из которых бо́льшую часть формируют Gyrodinium lachrymalfusiforme и Protoperidinium depressum (суммарно около $70 \%$ биомассы динофлагеллят). Около $20 \%$ общей биомассы микропланктона приходится на инфузорий, преимущественно хлорофиллсодержащих (Laboea strobila - около 50 \% биомассы инфузорий). При низком обилии диатомей доминирует Chaetoceros concavicornis (57 \% биомассы диатомей).

На горизонтах 40, 50 и 60 м ведущая роль в формировании общей биомассы микропланктона принадлежит диатомовым (около 50 \%), на динофлагеллят и инфузорий приходится, соответственно, около 35 и $13 \%$. На уровне видов доминируют Thalassiosira gravidalantarctica (около 55 \% биомассы диатомей), Protoperidinium depressum (около $40 \%$ биомассы динофлагеллят на горизонтах 40 и 50 м).

На глубине 70 и 80 м ведущая роль в формировании общей биомассы микропланктона принадлежит динофлагеллятам, диатомовым и гаптонемовым (Phaeocystis pouchetii) микроводорослям - 30, 45 и $23 \%$ общей биомассы планктона соответственно. На уровне таксонов видового ранга доминирует Protoperidinium islandicum (40 \% биомассы динофлагеллят) и Thalassiosira gravidalantarctica (около 30 \% биомассы диатомей).

На горизонтах 90, 100 и 110 м уровень обилия микропланктона крайне низок. Можно отметить, что единственный идентифицированный таксон, обеспечивающий заметный вклад в общую биомассу микропланктона, - Phaeocystis pouchetii (10-40\%). 
Станция 21 (рис. 4Г,Д,Е). Термохалинная структура пелагиали: верхний перемешанный слой - 0-34 м, верхний слой скачка - 35-63 м, подповерхностный слой - 64-110 м, нижний слой скачка - 111-122 м, придонный слой - 123-141 м.

Верхний квазиоднородный слой характеризуется сравнительно высокой для станции температурой воды $-1.34-1.27^{\circ} \mathrm{C}$ и минимальной соленостью - 34.57-34.59 psu. Верхний слой скачка представляет собой острый галоклин (GradS = $0.012 \mathrm{psu} / \mathrm{M})$. Рост значений солености в галоклине сопровождается в верхней части слоя скачка (35-42 м) небольшим ростом температуры $\left(\mathrm{Grad}=0.03{ }^{\circ} \mathrm{C} / \mathrm{M}\right)$, в нижней части слоя скачка (43-63 м) - снижением температуры с градиентом обратного знака $\left(\mathrm{Grad}=-0.01{ }^{\circ} \mathrm{C} / \mathrm{M}\right)$. В слое $43-48$ м отмечены максимальные значения температуры на станции - примерно $1.6{ }^{\circ} \mathrm{C}$. Подповерхностный слой представляет собой слабо выраженный термоклин $\left(\mathrm{GradT}=-0.03{ }^{\circ} \mathrm{C} / \mathrm{M}\right)$, в целом гомохалинный $(\mathrm{GradS}=0.000 \mathrm{psu} / \mathrm{M})$, но с заметно варьирующей соленостью от 34.91 до $34.94 \mathrm{psu}$. Он отделяется от придонного слоя с однородной соленостью (примерно $34.92 \mathrm{psu}$ ) и температурой (примерно $-0.4{ }^{\circ} \mathrm{C}$ ) слабо выраженным нижним слоем скачка (111-122 м), градиенты в котором $\left(\mathrm{GradT}=-0.04{ }^{\circ} \mathrm{C} / \mathrm{M}, \mathrm{GradS}=-0.001 \mathrm{psu} / \mathrm{м}\right)$ лишь незначительно повышены, чем в вышележащих горизонтах.

Распределение микропланктона на станции исследовалось по всему вертикальному профилю (10 проб). Отмечено 68 таксонов видового ранга.

Распределение микропланктона характеризуется подповерхностным пиком биомассы (рис. 4Е), формируемым на 75 \% представителями рода Thalassiosira.

Численность микропланктона в слое 0-25 м на 80-90 \% обусловлена Dinobryon balticum. Ниже по профилю доминируют Phaeocystis pouchetii и представители диатомовых Centrales/Thalassiosira, на горизонте 80 м и ниже также гипноспоры Chaetoceros socialis. На эти три группы приходится около 70 \% общей численности в слое 60-140 м.

Анализ таксономического сходства показал, что в пелагиали можно выделить три комплекса видов, локализованных по вертикали следующим образом: $0,10,25 ; 40,50 ; 80,100,110,140$ м. Каждый из комплексов имеет в составе определенное число видов, характерных только для него. Таксоценоз, отмеченный на глубине 60 м, характеризуется отсутствием таких специфических видов и высоким сходством с комплексами соседних слоев $(K=0.6)$, поэтому в равной степени может быть включен в один из них.

В структуре биомассы на трех верхних горизонтах ведущая роль принадлежит динофлагеллятам, составляющим более 90 \% общей биомассы микропланктона. На уровне вида в этой группе доминируют Protoperidinium depressum и Gyrodinium lachrymalfusiforme (суммарно $60 \%$ биомассы динофлагеллят). 


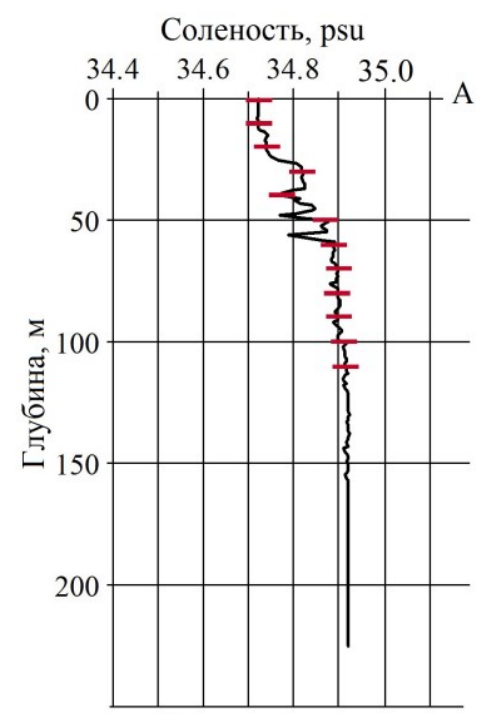

Температура, ${ }^{\circ} \mathrm{C}$
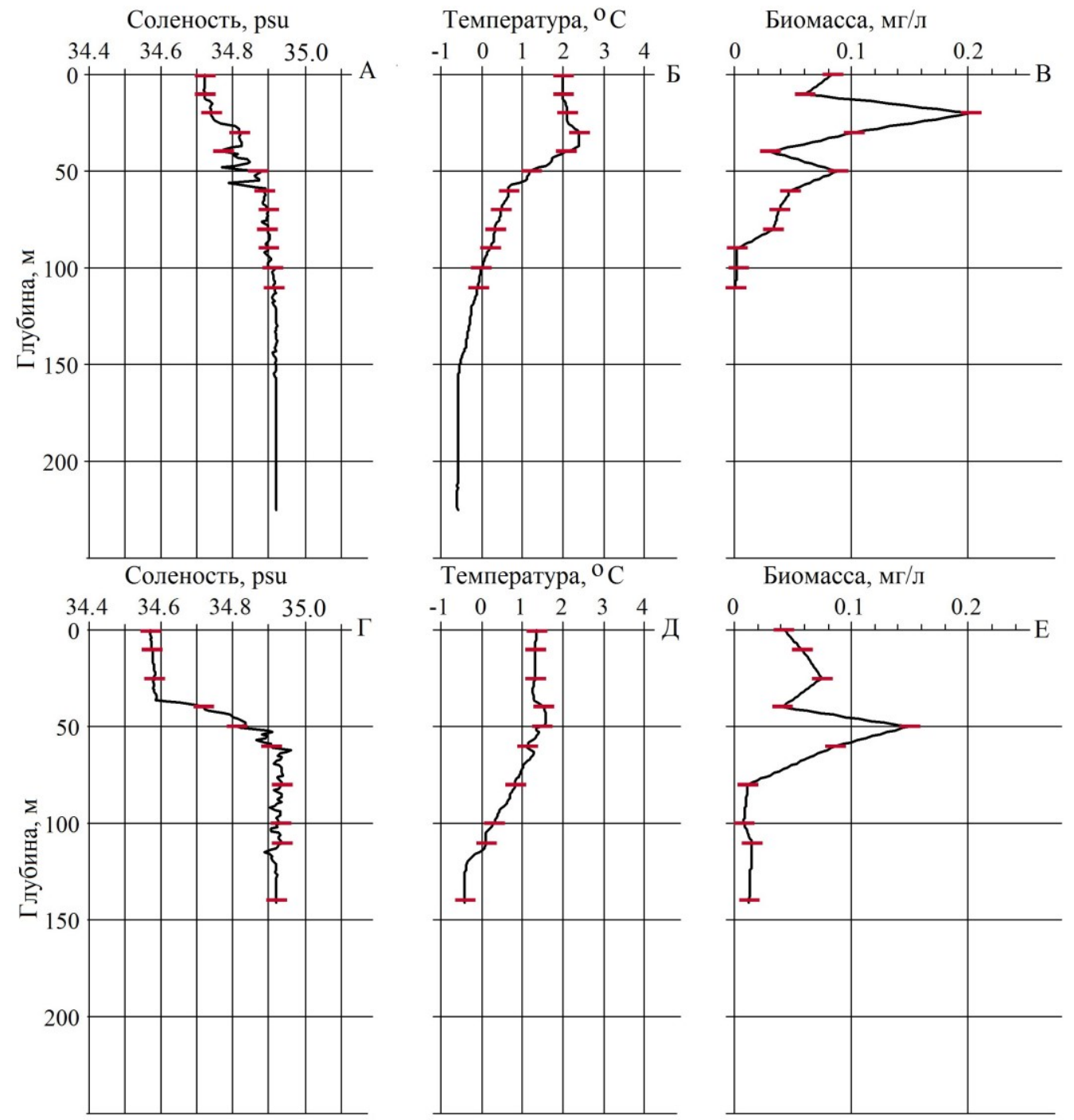

Рис. 4. Вертикальное распределение температуры, солености и общей биомассы микропланктона на станциях 20 (А, Б, В) и 21 (Г, Д, Е). Красными метками отмечены горизонты, исследованные на микропланктон

Fig. 4. Vertical distribution of the water temperature, salinity and total biomass of microplankton at the stations 20 (A, Б, B) and 21 (Г, Д, E). Red marks are noted horizons of microplankton research

Ниже по профилю структура биомассы меняется, так на горизонте 40 м доля динофлагеллят в общей биомассе составляет $50 \%$, доля диатомей - около 30 \%. Из видов доминируют Protoperidinium depressum и Gyrodinium lachrymalfusiforme (около 70 \% биомассы динофлагеллят). На горизонте 50 м доля динофлагеллят в общей биомассе составляет $15 \%$, доля диатомей $-80 \%$. Представители рода Thalassiosira преобладают (95 \% общей биомассы диатомей). На всех нижележащих горизонтах 
сохраняется структура микропланктона с доминированием диатомей, на глубине 60 и 80 м их доля доходит до $85 \%$ общей биомассы (в основном неидентифицированные Centrales/Thalassiosira).

Обсуждение. На станциях 15, 17 выявляется сходство структуры и термохалинных характеристик водной толщи, таксономического состава и уровня обилия микропланктона. В структуре водной толщи отмечены одни и те же элементы, сходно локализованные по вертикали. Суммарная мощность верхнего квазиоднородного слоя и подстилающего его верхнего слоя скачка составляет 50-60 м, присутствует придонный слой мощностью 23 м, который сверху ограничен нижним (придонным) слоем скачка. Термохалинные характеристики верхнего перемешанного слоя $\left(S \approx 34.95 \mathrm{psu}, \mathrm{T} \approx 4{ }^{\circ} \mathrm{C}\right)$ и подповерхностного слоя $(S \approx 34.94-34.96 \mathrm{psu}$, $T \approx 4-2{ }^{\circ} \mathrm{C}$ ) соответствуют параметрам водной массы атлантического происхождения (Pfirman et al., 1994; Бойцов, 2006), придонного слоя $\left(S \approx 34.945-34.935 \mathrm{psu}, T \approx 0.5-0.4{ }^{\circ} \mathrm{C}\right)$ - параметрам вод, обозначенным ранее как воды Полярного фронта (Harris et al., 1998). Обилие микропланктона на обеих станциях распределено сходным образом и формируется одним набором видов. Биомассы микропланктона характеризуются высокими значениями в пределах верхнего квазиоднородного слоя и резким снижением под верхним слоем скачка. Структура доминирования и изменение ее по вертикали также однотипны. В пределах верхнего квазиоднородного слоя в равной мере доминируют динофлагелляты и диатомеи, в составе каждой группы одни и те же виды-доминанты - Chaetoceros concavicornis, Chaetoceros diadema, Gyrodinium lachryma/fusiforme, Protoperidinium depressum. При "переходе" через слой скачка не только резко снижается уровень обилия, но из состава доминантов на уровне высших таксонов “выпадают" динофлагелляты, доминируют те же виды диатомей, что и в поверхностном слое. Состав микропланктона, несмотря на существенное таксономическое единство в пределах верхнего перемешанного и подповерхностного слоя, выделяется значительным видовым богатством на верхних горизонтах обеих станций.

Структурные элементы на ст. 19 те же, что и на станциях 15 и 17, однако термохалинные характеристики водной толщи заметно отличаются. Так в верхнем перемешанном слое $\left(S \approx 34.95 \mathrm{psu}, T \approx 4{ }^{\circ} \mathrm{C}\right)$ они соответствуют параметрам водной массы атлантического происхождения, однако в подповерхностном слое такой тип вод можно выделить только в слое 90-120 м ( $\left.S \approx 34.945-34.95 \mathrm{psu}, T \approx 2{ }^{\circ} \mathrm{C}\right)$, вышележащие $\left(S \approx 34.93 \mathrm{psu}, T \approx 2{ }^{\circ} \mathrm{C}\right)$ и нижележащие $\left(S \approx 34.93-34.91 \mathrm{psu}, T \approx 1-0{ }^{\circ} \mathrm{C}\right)$ воды - параметрам вод Полярного фронта (Harris et al., 1998). По составу микропланктона на этой станции четко выделяются два комплекса видов, а граница их разделяющая, находится на глубине 80-100 м (гораздо ниже сезонного слоя скачка). Комплекс верхнего слоя мало отличается от такового станций 15 и 17, те же доминанты и такой же характер 
распределения по вертикали общей биомассы. Комплекс микропланктона нижнего слоя характеризуется высоким видовым богатством и наличием большого числа специфических видов. Структура доминирования в этом слое на видовом уровне не выявлена. В составе присутствуют видыдоминанты верхнего слоя, но в малом числе, а большая часть биомассы сформирована неидентифицированными до вида диатомеями.

В структуре водной толщи ст. 18 отмечены те же элементы, что и на предыдущих станциях. Верхний перемешанный слой небольшой мощности, так что верхний слой скачка почти выклинивается на поверхность. Термохалинные характеристики верхнего перемешанного слоя $\left(S \approx 34.94 \mathrm{psu}, T \approx 4{ }^{\circ} \mathrm{C}\right)$, слоя скачка $\left(S \approx 34.94-34.90 \mathrm{psu}, T \approx 4-3{ }^{\circ} \mathrm{C}\right)$ и прилегающих горизонтов до глубины 80 м соответствуют параметрам вод Полярного фронта, в слое 90-110 м (где изучен микропланктон) и ниже по профилю - водной массе атлантического происхождения. По составу и структуре доминирования микропланктон на этой станции имеет как несомненное сходство, как и отличия от станций 15, 17 и 19. Сходство наблюдается в общем распределении биомассы по вертикали (имеется подповерхностный максимум), таксономическом составе микропланктона верхнего квазиоднородного слоя - высокое сходство таксоценов всех четырех станций на уровне 0.7-0.8. Однако структура биомассы резко отличается от таковой на станциях 15, 17 и 19 - на уровне таксонов высшего ранга доминируют динофлагелляты, диатомеи занимают подчиненное положение и в этой группе на видовом уровне также наблюдается частичная смена доминантов (Chaetoceros concavicornis, Thalassiosira gravida/antarctica, Thalassiosira nordenskioeldii).

Термохалинная структура водной толщи на станциях 20 и 21 в пределах верхних 110 м имеет очевидное сходство. Можно выделить воды Полярного фронта, локализованные в нижней части слоя скачка $\left(S \approx 34.90-34.80 \mathrm{psu}, T \approx 2.0-0.7^{\circ} \mathrm{C}\right)$ и ниже, до горизонта 110 м $(S \approx 34.9 \mathrm{psu}$, $\left.T \approx 0.7 \ldots-0.2^{\circ} \mathrm{C}\right)$. Вода верхнего перемешанного слоя и прилегающей к нему части слоя скачка (0-30 м) по термохалинным характеристикам $\left(S \approx 34.7-34.6 \mathrm{psu}, T \approx 1-2{ }^{\circ} \mathrm{C}\right)$ соответствует арктическим водам, прогретым и распресненным в процессе таяния льда (mixed meltwater по: Harris et al., 1998). В отличие от станций $15,17,18,19$, на станциях 20 и 21 верхний слой скачка четко разделяет два разных микропланктонных ценоза, хорошо различимые по особенностям таксономического состава и особенно - по структуре доминирования. В структуре биомассы микропланктона над слоем скачка ведущая роль принадлежит динофлагеллятам, на обеих станциях доминируют Protoperidinium depressum и Gyrodinium lachryma/fusiforme, под слоем скачка диатомовые рода Thalassiosira. Соответственно, на профиле биомассы на каждой из этих станций выделяется два максимума - верхний, сформированный динофлагеллятами, и нижний, который обусловлен преимущественно диатомеями. 
Авторы выражают благодарность сотруднику лаборатории океанографии и радиоэкологии ММБИ РАН Т.М. Максимовской за предоставление гидрологических данных СТД-зондирования по итогам научно-исследовательского рейса НИС “Дальние Зеленцы”.

Работа выполнена по теме “Особенности организации арктических планктонных сообществ в условиях современных климатических изменений (Баренцево, Карское моря и море Лаптевых)" (№ ААА-А-А17-117052310083-5) в рамках государственного задания (№ 0228-2019-0003).

\section{Литература}

Бойцов В.Д. Изменчивость температуры воды Баренцева моря и ее прогнозирование. Мурманск: Изд-во ПИНРО, 2006. 292 с.

Кольцова Т. И. Определение объема и поверхности клеток фитопланктона // Биол. науки. 1970. № 6. С. 114-120.

Harris C.L., Plueddemann A.J., Gawarkiewicz G.G. Water mass distribution and polar front structure in the western Barents Sea // J. Geophys. Res. 1998. Vol. 103, № C2. P. 2905-2917.

Makarevich P.R., Larionov V.V., Druzhkov N.V. Average cell weights of the mass phytoplankton species of the Barents Sea. Prepr. Apatity: Publ. KSC Acad. Sci. USSR, 1990. $14 \mathrm{p}$.

Makarevich P.R., Larionov V.V., Druzhrov N.V. Mean weights of dominant phytoplankton species of the Barents Sea // Algology. 1993. Vol. 13, № 1. C. 103-106.

Pfirman S.L., Bauch D., Gammelsrod T. The northern Barents Sea: water mass distribution and Modification // The polar oceans and their role in shaping the global environment. Washington D.C.: Am. Geophys. Union, 1994. Vol. 85.P. 77-94.

DOI: $10.37614 / 2307-5252.2021 \cdot 3 \cdot 9.015$

УДК 551.464 .32

\section{И.А. Пастухов}

Мурманский морской биологический институт РАН, г. Мурманск, Россия

\section{ГИДРОХИМИЧЕСКИЕ ИССЛЕДОВАНИЯ НА РАЗРЕЗЕ "КОЛЬСКИЙ МЕРИДИАН" С ИСПОЛЬЗОВАНИЕМ ИЗОТОПНОГО ТРАССЕРА $\delta^{180}$}

\section{Аннотация}

Представлены результаты гидрохимических исследований на 10 станциях разреза "Кольский меридиан", выполненных в экспедиции НИС "Дальние Зеленцы" в апреле 2019 г., где определялись концентрации фоссратного фоссрора, нитратного азота и кремния. Для анализа данных применялась методика с использование изотопного трассера $\delta^{18} 0$. Мера продукции и деструкции избранных биогенных элементов определялась авторским методом. Выделены два предполагаемых 
очага фитопланктонной активности: области в районе ледовой кромки на севере разреза и в водах Мурманского прибрежного течения. Состояние вод на разрезе определено как поздневесеннее.

Ключевые слова: изотопы кислорода, ледообразование, ледотаяние, атлантические воды, речные воды, морские воды, гидрохимия, Баренцево море, разрез "Кольский меридиан".

\title{
I.A. Pastukhov \\ Murmansk Marine Biological Institute RAS, Murmansk, Russia \\ HYDROCHEMICAL STUDIES ON THE TRANSECT "KOLA MERIDIAN" USING THE $\delta^{180}$ ISOTOPE TRACER
}

\begin{abstract}
The results of hydrochemical studies at 10 stations of the transect "Kola meridian" opencast performed on the expedition NIS "Dalnye Zelentsy" in April 2019, where hydrochemical studies of phosphate phosphorus, nitrate nitrogen and silicon were performed, are presented. To analyze the data, a technique using the $\delta^{18} \mathrm{O}$ isotope tracer was used. The measure of production and destruction of selected nutrients was determined by the author's method. Two alleged foci of phytoplankton activity were identified: areas in the region of the ice edge in the north of the section and in the waters of the Murmansk coastal course. The state of the waters in the section is defined as late spring.
\end{abstract}

Keywords: oxygen isotopes, ice formation, ice melting, Atlantic waters, river waters, sea waters, hydrochemistry, the Barents Sea, transect "Kola meridian".

Введение. Для понимания развития морских экосистем нужна корректная система координат. В океанографии используются понятие “фоновые концентрации”, четкого определения которых, тем не менее, не дается. Например, в работах О.В. Титова $(2001,2002)$ эта величина для фосфора фосфатного в морских водах определяется как предстартовое содержание минерального фосфора в водной толще в районах, освободившегося от ледяного покрова. Данную величину очень трудно определить по нескольким причинам.

Во-первых, речь идет о районах, освободившихся от льда. А как определить данную величину в районах Баренцева моря, в которых ледовые процессы не наблюдаются?

Во-вторых, как вообще определить данную величину? Строить годовой цикл изменения исследуемого параметра в каждой точке моря?

В-третьих, изменение какого-либо параметра из-за адвекции и других гидрологических факторов, в частности концентрации кремния, может превышать таковое под воздействием процессов фотосинтеза или минерализации органического вещества. 
В представленной работе вводится понятие “фоновая” концентрация, которая определяется как концентрация какого-либо элемента при условии, что его изменения связаны только с процессами смешения с другими водами, а также с трансформацией вод, вызванной процессами ледообразования или ледотаяния (Namyatov et al., 2020). Разница между расчетной “фоновой” концентрацией и измеренной дает представление о величине и направленности таких гидрохимических процессов как фотосинтез или минерализация органического вещества. Данная величина не зависит от наличия или отсутствия ледовых явлений и от изменений исследуемого параметра за счет адвективных процессов.

Океанографический разрез “Кольский меридиан” выбран потому, что он характеризует в целом Баренцево море и происходящие в нем экологические процессы. Исследования на нем проводятся регулярно уже более 100 лет, что позволяет сравнивать наши результаты с большим массивом данных.

Цель работы - исследование продукционно-деструкционных процессов в весенний период на разрезе "Кольский меридиан".

Материал и методы. В ходе научной экспедиции Мурманского морского биологического института на НИС “Дальние Зеленцы” в апреле 2019 г. были проведены исследования гидрохимического состояния вод на океанографическом разрезе “Кольский меридиан” (рис. 1).

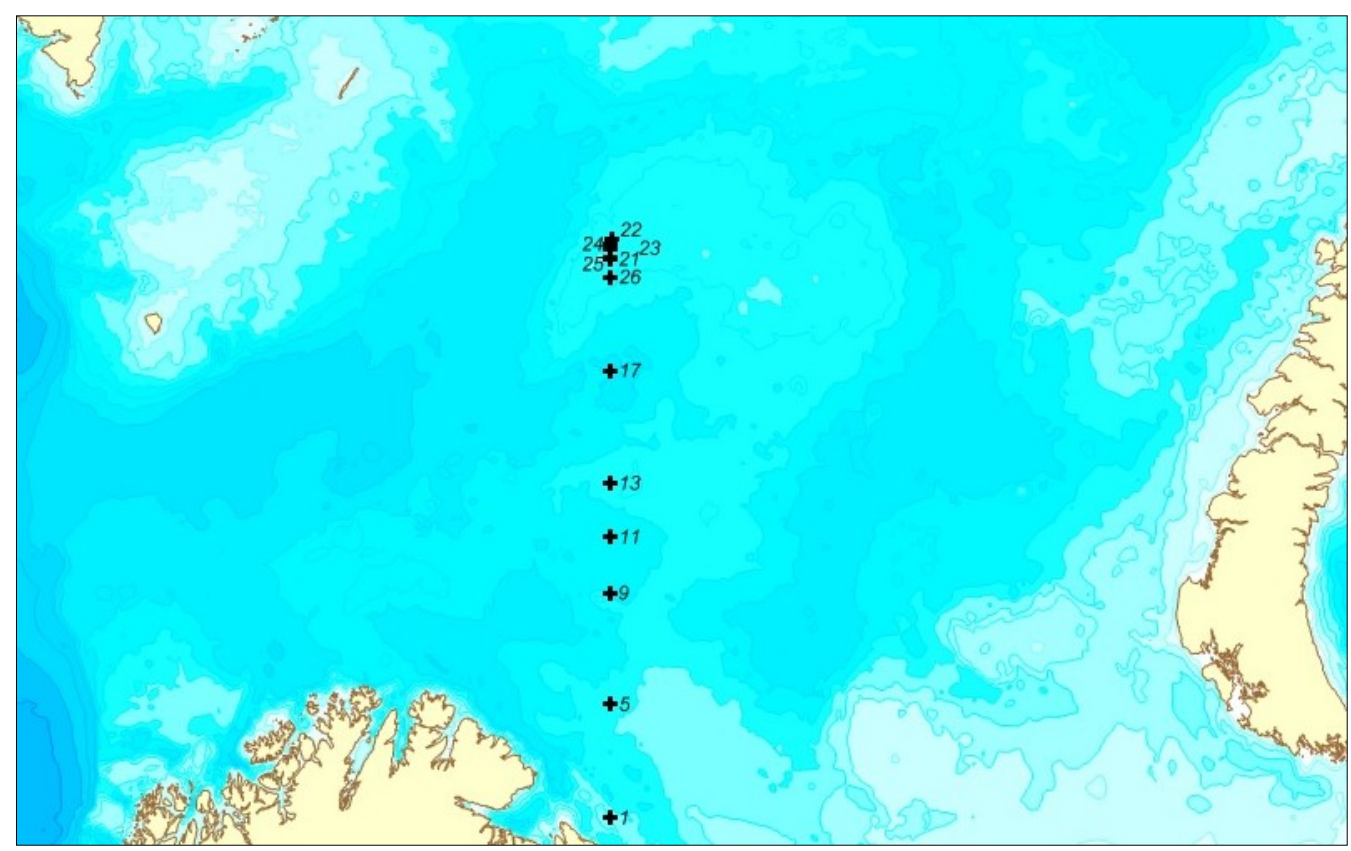

Рис. 1. Схема расположения станций на разрезе "Кольский меридиан" в апреле 2019 г.

Fig. 1. Scheme of hydrochemistry stations of the transect "Kola meridian" in April 2019 
На разрезе выполнено 10 гидрохимических станции, отобрано 53 пробы воды с помощью пластиковых батометров системы Нискина. При обработке проб использовали стандартные гидрохимические методы (Руководство ... 1993). Для сравнения привлечены данные аналогичных исследований 1982 г., выполненные на этом разрезе НИЛ “Отто Шмидт” (http://www.nodc.noaa.gov).

Для расчета “фоновых” концентраций гидрохимических параметров предполагалось, что все компоненты морской воды можно разделить на "консервативные" и “неконсервативные". Первые - это компоненты, концентрации которых в морской воде зависят только от процессов смешения различных вод или их модификации в процессе ледообразования или ледотаяния, например, соленость. Вторые - это компоненты, концентрация которых зависит не только от процессов смешения различных водных масс, но и от химико-биологических процессов, протекающих в морской экосистеме. Например, биогенные элементы. В данной работе используется модель (Никифоров, Шпайхер, 1980; Exchange ..., 2009; Bauch, Cherniavskaia, 2018), которая предполагает, что в Баренцевом море присутствует всего две базовые водные массы “чисто" атлантические и "чисто" речные воды, а все остальные являются результатом смешения и трансформации этих двух вод. В таком случае, “морские воды" - это реальные воды, в которых в той или иной пропорции смешаны атлантические и речные воды, подвергшиеся трансформации в результате ледотаяния или ледообразования, а количество тех или иных вод описывается системой уравнений смешения (Exchange ..., 2009):

$$
\begin{gathered}
f_{\mathrm{a}} S_{\mathrm{a}}+f_{\mathrm{r}} S_{\mathrm{r}}+f_{\mathrm{i}} S_{\mathrm{i}}=S_{\text {mean }} \\
f_{\mathrm{a}} O_{\mathrm{a}}+f_{\mathrm{r}} O_{\mathrm{r}}+f_{\mathrm{i}} O_{\mathrm{i}}=O_{\text {mean }} \\
f_{\mathrm{a}}+f_{\mathrm{r}}+f_{\mathrm{i}}=1,
\end{gathered}
$$

где а - атлантические воды; $\mathrm{r}$ - речные воды; $\mathrm{i}$ - ледовые воды; $S$ - соленость, $\mathrm{psu} ; O$ - величина $\delta^{18} \mathrm{O}, \% ; f$ - содержание тех или иных вод, $\% ; S_{\text {mean }}$ и $O_{\text {mean }}$ - измеренная соленость (psu) и величина $\delta^{18} \mathrm{O}(\%)$ морской воды соответственно.

Соотношение изотопов кислорода $\delta^{18} \mathrm{O}$ и $\delta^{16} \mathrm{O}$ в морской воде позволяет корректно определить речные воды, которые облегчены по изотопному составу, относительно более тяжелых атлантических вод. Однако крайне редко в доступных базах данных можно встретить совместное определение солености, $\delta^{18} \mathrm{O}$ и биогенных элементов, а вот данных по совместному определению только солености и биогенных элементов довольно много. Однако в нескольких работах показано (Bauch, Cherniavskaia, 2018), что существует довольно тесная корреляционная связь между величинами солености и $\delta^{18} \mathrm{O}$. Для Баренцева моря в настоящей работе построены графики зависимостей $\delta^{18} \mathrm{O} \div \mathrm{S}$ по материалам общедоступных баз данных NASA (http://data.giss. 
nasa.gov/o18data/ref.html) и NODC (http://www.nodc.noaa.gov). Всего для Баренцева моря в этих базах данных представлено около 2200 параллельных значений $\delta^{18} \mathrm{O}$ и солености. Графики зависимости между величинами солености и $\delta^{18} \mathrm{O}$ показаны на рис. 2 .

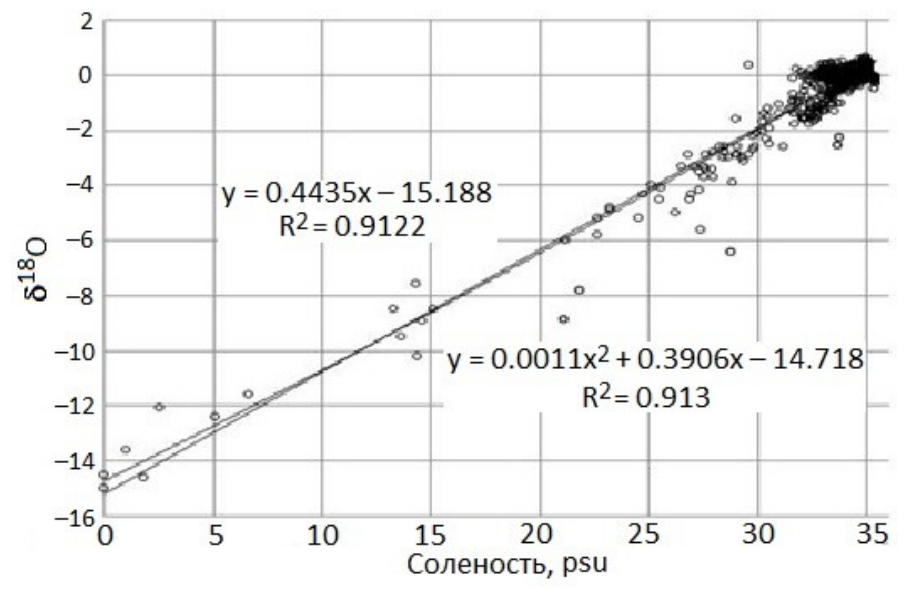

Рис. 2. Зависимости между величинами солености и $\delta^{18} \mathrm{O}$

Fig. 2. Relationship between salinity and $\delta^{18} \mathrm{O}$

Коэффициент корреляции в данном случае близок к $1\left(R^{2}=0.95\right)$. Так как на графике представлены все данные независимо от времени года и горизонта отбора проб, выдвинем гипотезу, что предлагаемое уравнение связи между величиной солености и $\delta^{18} \mathrm{O}$ применимо для всех значений солености (независимо от того, проводились ли измерения величины $\delta^{18} \mathrm{O}$ или нет). Выдвинутая гипотеза была проверена методом разбития ряда на две части фактически случайным образом по 1100 значений. Первоначально ряд ранжировался по солености от меньших значений к большим независимо от экспедиции, времени года или горизонта отбора проб. Затем четные значения составили первый ряд, а нечетные - второй. По данным первого ряда рассчитывалось уравнение связи солености и $\delta^{18} \mathrm{O}$. Затем по этому уравнению для второй части ряда по значениям солености вычислены значения $\delta^{18} \mathrm{O}$. Сравнение расчетных и измеренных значений показано на рис. 3 .

Между этими данными наблюдается линейная зависимость с высоким коэффициентом корреляции - 0.94. Для проверки равенства средних значений в двух выборках был использован $t$-критерий Стьюдента. Рассчитанное значение $t$-критерия составляет 0.089 , что гораздо меньше критического значения 1.960 для уровня значимости $p=0.05$ при числе степеней свободы равном 2150. Следовательно, выдвинутая гипотеза об отсутствии различий между двумя независимыми выборками подтверждается при уровне значимости 0.05. Поэтому, можно считать, что уравнения соотношения солености и величины $\delta^{18} \mathrm{O}$, 
представленные на рисунках 2 и 3 , распространяются за пределы рядов совместного наблюдения величин солености и $\delta^{18} \mathrm{O}$ и могут быть использованы для вычисления $\delta^{18} \mathrm{O}$ по величине солености. Итак, для любого полученного значения солености можно определить величину $\delta^{18} \mathrm{O}$, значение которого будет соответствовать измеренному в $95 \%$ случаев.

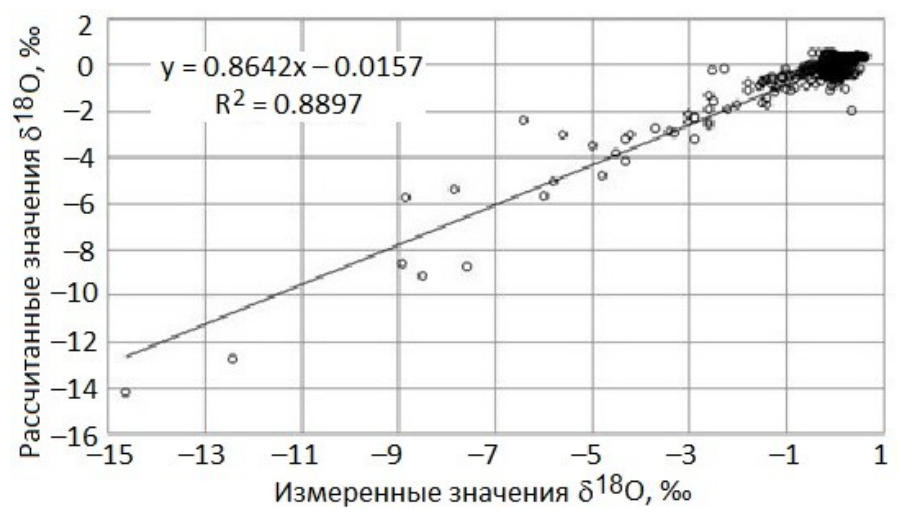

Рис. 3 Расчетные и измеренные значения $\delta^{18} \mathrm{O}$

Fig. 3. Calculated and measured values of $\delta^{18} \mathrm{O}$

Для расчета величин $f_{\mathrm{a}}, f_{\mathrm{r}}$ и $f_{\mathrm{i}}$ по системе уравнений (1) необходимо знать значения солености и $\delta^{18} \mathrm{O}$ в исходных водах - атлантических, речных и ледовых. Для этого воспользуемся значениями этих параметров, которые уже применялись в других работах (Bauch, Cherniavskaia, 2018), но уточненные для Баренцева моря по 288 пробам, \%о: $S_{\mathrm{a}}-35.04, O_{\mathrm{a}}-0.3$, $S_{\mathrm{r}}-0, O_{\mathrm{r}}--15, S_{\mathrm{i}}-5.86$ (по: Гидрометеорология $\left.\ldots, 1990\right), O_{\mathrm{i}}$ на поверхности - 2.6 (по: Bauch, Cherniavskaia, 2018).

Если предположить, что водные массы являются результатом смешения и трансформации двух базовых вод, концентрация консервативного элемента в этих водных массах будет определяться формулой

$$
f_{\mathrm{a}} C_{\mathrm{a}}+f_{\mathrm{r}} C_{\mathrm{r}}+f_{\mathrm{i}} C_{\mathrm{i}}=C f
$$

где $C_{\mathrm{a}}, C_{\mathrm{r}}$ и $C_{\mathrm{i}}$ - концентрация исследуемого элемента в “чисто" атлантических, “чисто” речных и “ледовых” водах (таблица); $C f-$ фоновая концентрация исследуемого элемента.

Принимаем, что разница между измеренной концентрацией и фоновой будет определять величину “неконсервативности”. В случае с биогенными элементами эта величина показывает количество данного элемента, участвующего в процессах продукции и деструкции органического вещества:

$$
\Delta C_{\mathrm{j}}=C_{\mathrm{j}}-C f_{\mathrm{j}}
$$


где $\Delta C_{\mathrm{j}}<0$ - потребление (фотосинтез); $\Delta C_{\mathrm{j}}>0$ - поступление (минерализация в результате окисления органического вещества); j рассматриваемый элемент (фосфор, кремний, азот или любой другой).

Величины исследуемых параметров в исходных водных массах The values of the researched parameters in the initial water masses

\begin{tabular}{l|c|c|c|c}
\hline \multicolumn{1}{c|}{ Водные массы } & $\begin{array}{c}\text { Соленость, } \\
\mathrm{psu}\end{array}$ & $\begin{array}{c}\mathrm{P}-\mathrm{PO}_{4}, \\
\text { мкг/л }\end{array}$ & $\begin{array}{c}\mathrm{N}-\mathrm{NO}_{3}, \\
\text { мкг/л }\end{array}$ & $\begin{array}{c}\mathrm{Si}-\mathrm{SiO}_{3}, \\
\text { мкг/л }\end{array}$ \\
\hline Атлантические, $C_{a}$ & 35.00 & 21.4 & 102 & 129 \\
Речные, $C_{\mathrm{r}}$ & 0 & 26.1 & 80.6 & 3050 \\
Ледовые, $C \mathrm{Ci}$ & 5.86 & 11.1 & 24.8 & 30.9
\end{tabular}

ПРИМЕЧАНИЕ. $C_{\text {a }}$ - средние значения представленных параметров для слоя 0-200 м с января по февраль на полигоне в западной части Баренцева моря (Namyatov et al., 2020). Данный период времени года для выборки принят с тем, чтобы обеспечить максимальные значения средних концентраций биогенных элементов, уменьшение которых начнется в весенний период с началом интенсификации фотосинтеза; $C_{\mathrm{r}}-$ средние значения за 10 лет (2006-2016 гг.), рассчитанные по ежегодникам "Качество поверхностных вод"; $C_{\mathrm{i}}-$ средние значения солености и концентраций биогенных элементов, рассчитанные по: Гидрометеорология ..., 1990.

Результаты и обсуждение. На распределение гидрохимических параметров в любое время года значительное влияние оказывает положение водных масс. Для Баренцева море это особенно характерно, так как из-за сложного рельефа дна взаимодействие холодных арктических течений и теплых ветвей Нордкапского течения образует сложную гидрологическую структуру. С помощью построенных графиков распределения температуры и солености на разрезе (рис. 4) удалось выделить влияние нескольких гидрологических районов:

Мурманское прибрежное течение: ст. 1, на глубине 25-50 м, характеризуется наименьшей соленостью и температурой около $4{ }^{\circ} \mathrm{C}$;

Мурманское течение - ст. 5, в придонных слоях глубже 100 м, температура до $4.4{ }^{\circ} \mathrm{C}$ и соленость $34.7-34.8 \mathrm{psu}$;

Центральная ветвь Нордкапского течения - станции 13-17, на глубине 25-50 м, температура $2.5-2.8^{\circ} \mathrm{C}$, соленость $34.9 \mathrm{psu}$;

"Прикромочная" область - станции 22-26, характеризуется взаимодействием холодных вод Центрального течения и теплых вод Центральной и Северной ветвей Нордкапского течения, температура не превышает $1.2^{\circ} \mathrm{C}$ на поверхности, соленость выше $34.9 \mathrm{psu}$.

Для описания гидрохимического состояния вод в исследуемый период первоначально рассмотрим как работает расчет величины консервативности на примере классического рейса ледокола “Отто Шмидт” в апреле 1982 г. по разрезу “Кольский меридиан” (рис. 5). Разрез 
выполнен во время гидрологического лета. Потребление биогенных элементов, в данном случае фосфатов (величина $\Delta C_{\mathrm{j}}$ имеет отрицательные значения), наблюдается в поверхностном слое, а минерализация (положительные значения) - у дна, что является классическим летним типом распределения гидрохимических параметров.
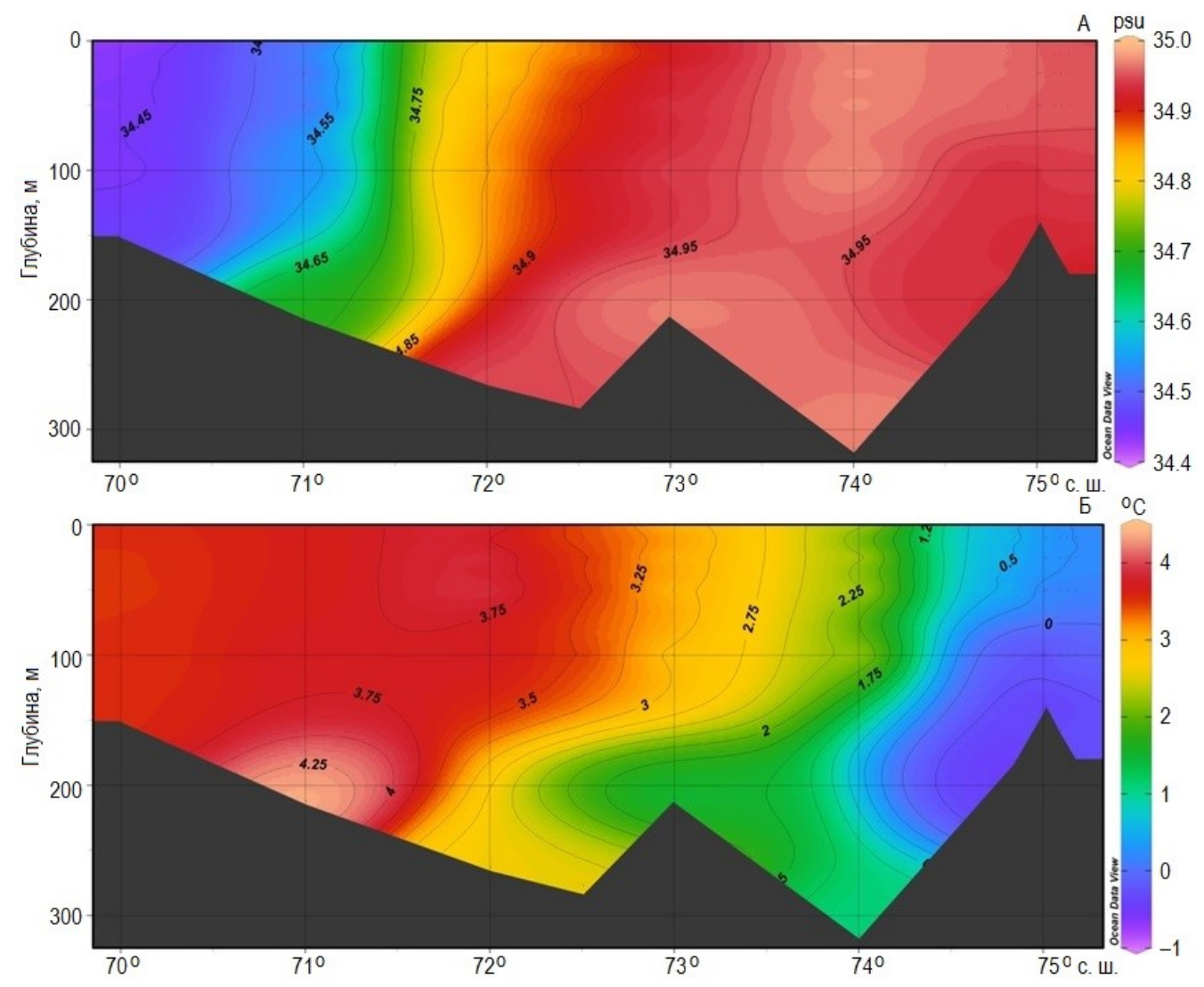

Рис. 4. Распределение солености (А) и температуры (Б) на разрезе в апреле 2019 г. Fig. 4. Distribution of salinity (A) and temperature (B) at the transect in April 2019

Максимальное потребление фосфора фосфатного наблюдалось в южной части разреза (9-11 мкг/л) и составляло около $50 \%$ (рис. 5A). Максимальные величины минерализации органического вещества отмечены в придонном слое 200-300 м, где превышение фосфатов над фоновыми значениями составляло от 9 до 11 мкг/л.

По такому же алгоритму были построены и проанализированы графики распределения величины “неконсервативности" некоторых гидрохимических параметров на разрезе “Кольский меридиан", полученные в ходе исследований в апреле 2019 г. (рис. 6), когда еще не сформировались вертикальные градиенты температуры и солености. 

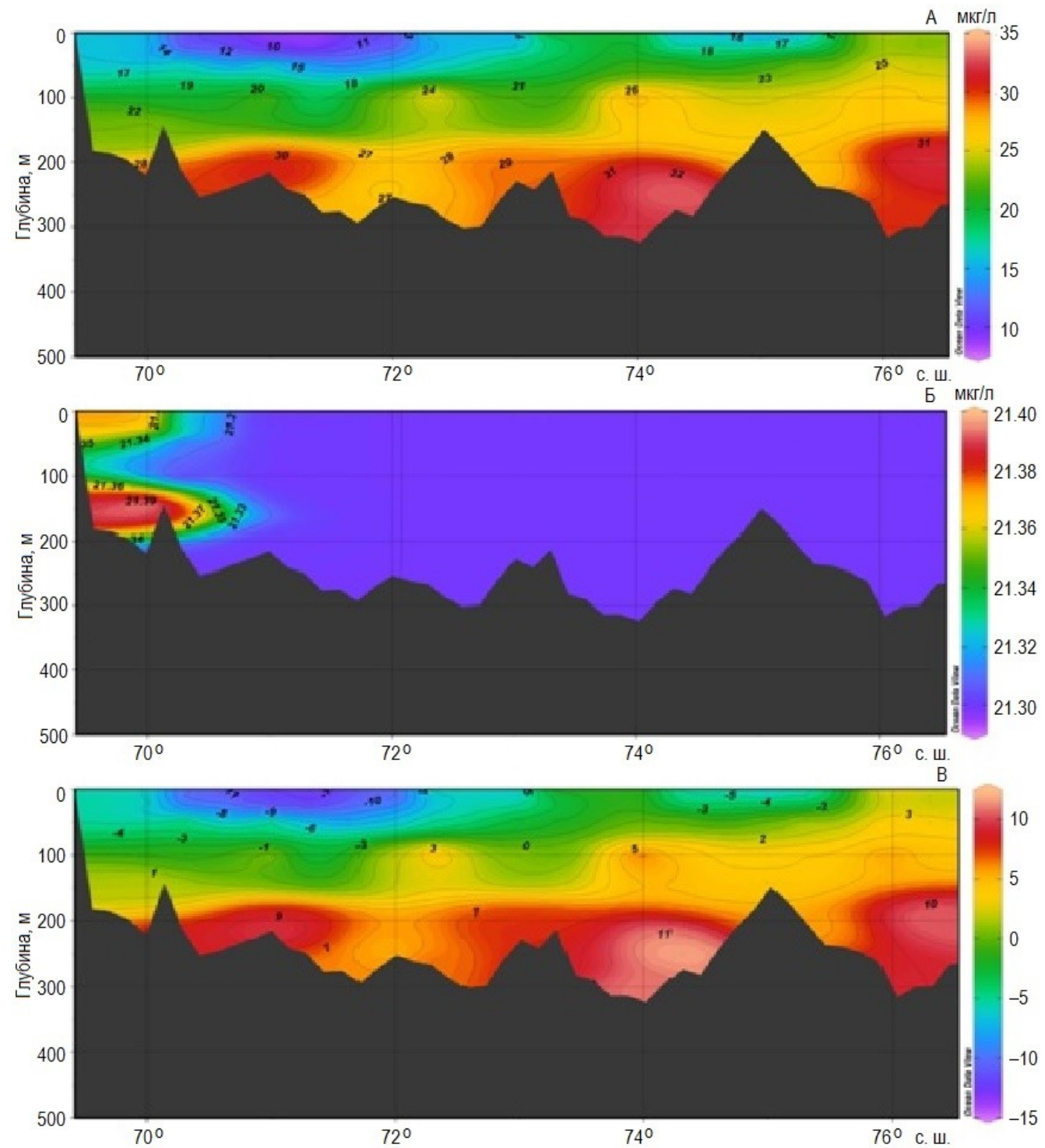

Рис. 5. Распределение концентраций фосфора фосфатного:

А - измеренные значения, мкг/л; Б - “фоновые” значения, мкг/л; В - величина “неконсервативности” на разрезе, апрель 1982 г.

Fig. 5. Distribution of phosphate phosphorous concentrations:

A - measured values, $\mu \mathrm{g} / \mathrm{l}$; Б - background values, $\mu \mathrm{g} / \mathrm{l}$; B - "non-conservative" value at the transect, April 1982

Как в поверхностном, так и в придонном слоях можно встретить как положительные, так и отрицательные значения dP, dN и dSi. Распределение очагов потребления биогенных элементов носит мозаичный характер, что типично для весеннего периода. 

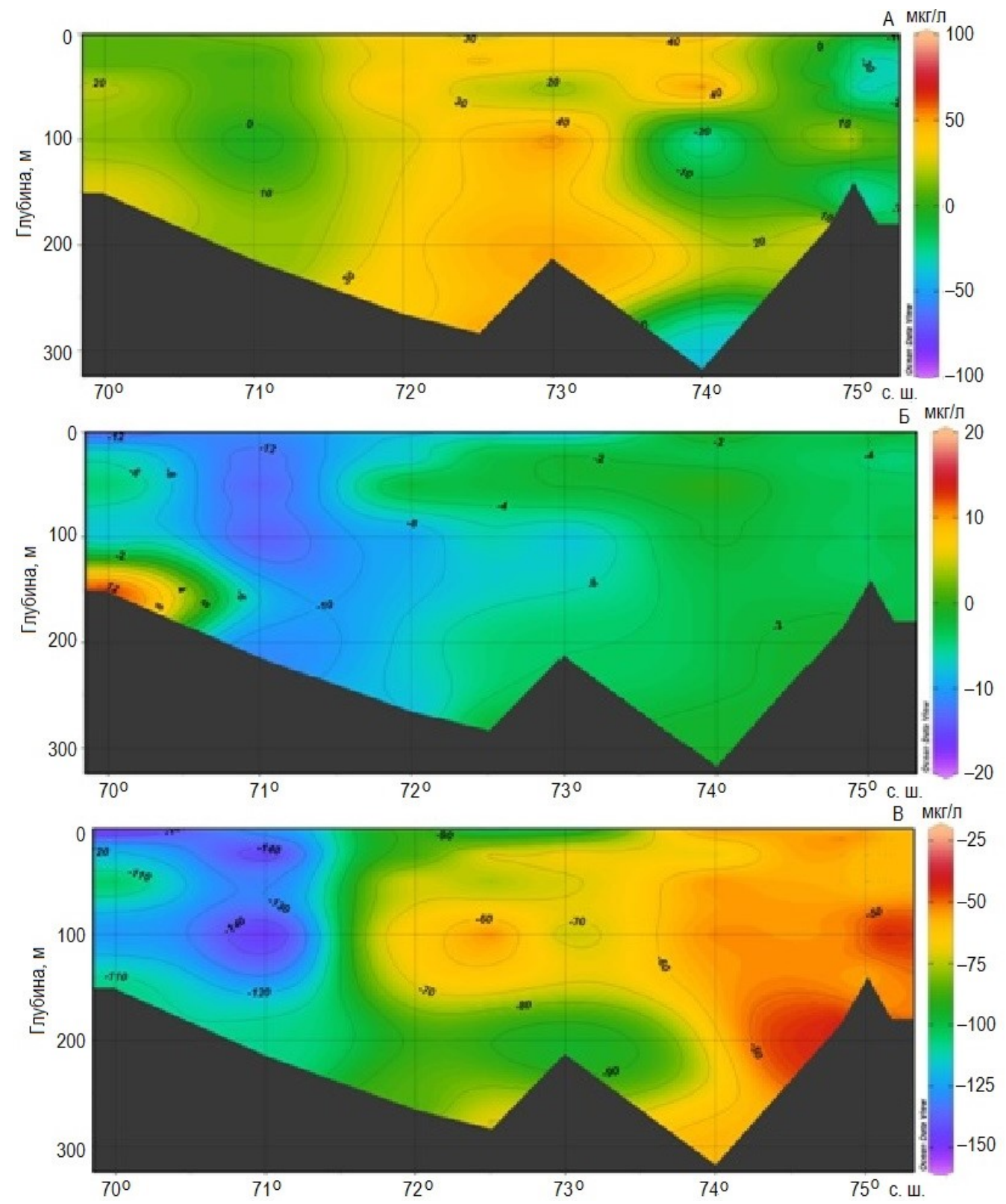

Рис. 6. Распределение величин “неконсервативности” азота (А), фосфора (Б) и кремния (В) на разрезе "Кольский меридиан" в апреле 2019 г. по итогам рейса НИС “Дальние Зеленцы”

Fig. 6. Distribution of "non-conservative" values of nitrogen (A), phosphorus (Б) and silicon (B) at the transect "Kola meridian" in April 2019 (R/V "Dalnye Zelentsy")

Максимальные объемы потребления азота нитратного наблюдались на северных станциях, которые находились вблизи кромки отступающего льда. На всем остальном пространстве разреза южнее $74^{\circ}$ отмечено равномерное распределение положительных величин “неконсервативности”, 
что характеризует эти воды как “зимние”. Фосфор фосфатный извлекался из водной толщи разреза в небольших количествах, исключение придонный горизонт прибрежной станции. По-видимому, это связано с материковым стоком и опусканием органического вещества на дно, где уровень его потребления меньше такового поступления. Кремний извлекался из толщи воды на всем пространстве разреза без исключения, что, вероятнее всего, объясняется ростом популяции диатомовых водорослей, которые активно строят из него свой “панцирь”. Они особенно активны в весенний период. Максимальное различие $(\Delta)$ концентрации кремния до 150 мкг/л отмечено в прибрежных водах Мурманского течения, здесь же регистрируется максимальный диапазон концентраций фосфора - 14 мкг/л. На некоторых станциях в этом районе изменение концентрации азота также отрицательно (-7.2 мкг/л). Это можно сказать и о прикромочных станциях: азот - до -80 мкг/л, кремний - до -60 мкг/л и фосфор - до -5 мкг/л.

Заключение. Данные, полученные на разрезе "Кольский меридиан" в апреле 2019 г., показывают, что гидрологическое лето еще не наступило (подтверждается картиной распределения гидрохимических параметров и величиной “неконсервативности” рассчитанной для них). Благодаря исследованиям, были зарегистрированы два очага "извлечения" биогенных элементов: в водах Мурманского прибрежного течения и в "прикромочных" областях на севере разреза, что может свидетельствовать о вспышках развития фитопланктона, являющиеся маркерами перехода к летнему типу распределения гидрохимических параметров. Вместе с тем, это подтверждает теорию о начале “цветения” фитопланктона в северных морях вблизи ледовой кромки.

Автор выражает благодарность за помощь в подготовке статьи научному руководителю к.г.н. А.А. Намятову.

\section{Литература}

Гидрометеорология и гидрохимия морей СССР. Т. 1. Баренцево море. Вып. 1. Гидрометеорологические условия. Л.: Гидрометеоиздат, 1990. 280 с.

Никифоров Е.Г., Шпайхер А.О. Закономерности формирования крупномасштабных колебаний гидрологического режима Северного Ледовитого океана. Л.: Гидрометеоиздат, 1980. $272 \mathrm{c.}$

Руководство по химическому анализу морских вод. Л.: Гидрометеоиздат, 1993. $263 \mathrm{c}$.

Титов O.B. Многолетние изменения гидрохимических характеристик на разрезе "Кольский меридиан” как показатель изменений в экосистеме Баренцева моря // Океанология. 2001. Т. 41, № 4. С. 518-526.

Титов O.B. Многолетние изменения содержания минеральных форм фосфора в Баренцевом, Норвежском морях и Северо-Восточной Атлантике // Океанология. 2002. Т. 42, № 6. С. 848-854. 
Bauch D., Cherniavskaia E. Water mass classification on a highly variable arctic shelf region: Origin of Laptev Sea water masses and implications for the nutrient budget // J. Geophysical Res. 2018. Oceans, 123. URL: https://doi.org/10.1002/2017JC013524

Exchange of Laptev Sea and Arctic Ocean halocline waters in response to atmospheric forcing / D. Bauch, I. Dmitrenko, C. Wegner et al. // J. Geophysical Res. 2009. Vol. 114. C005008. DOI: 10.1029/2008JC005062

Namyatov A., Pastukhov I., Semeruk I. Applying the $\delta^{18} \mathrm{O}$ parameter for evaluating of organic matter production-destruction processes in the Barents Sea // KnE Life Sci. 2020. Vol. 5(1). P. 615-623. URL: https://doi.org/10.18502/kls.v5i1.6137

DOI: $10.37614 / 2307-5252.2021 .3 .9 .016$

УДК 594 (268.45)

\section{3.Ю. Румянцева 1 , И.О. Нехаев²}

${ }^{1}$ Мурманский морской биологический институт РАН, г. Мурманск, Россия

${ }^{2}$ Санкт-Петербургский государственный университет, г. Санкт-Петербург, Россия

\section{РАСПРОСТРАНЕНИЕ РАКОВИННЫХ БРЮХОНОГИХ МОЛЛЮСКОВ В ОТКРЫТЫХ ЧАСТЯХ БАРЕНЦЕВА МОРЯ: ПРЕДВАРИТЕЛЬНЫЙ АНАЛИЗ}

\section{Аннотация}

Видовой состав и распределение раковинных брюхоногих моллюсков в Баренцевом море описаны только для прибрежных регионов. Нами были использованы 530 проб с 247 станций из удаленных от берега районов. В ряде случаев распределение моллюсков зависело от типа субстрата, а в остальных - выявлена только приуроченность к географическому местоположению. Последнее, вероятно, обусловлено гидрологическими факторами или наличием исторически сложившихся фаунистических комплексов. Применение разных подходов к удалению малоинформативных проб при анализе дает схожие результаты.

Ключевые слова: брюхоногие моллюски, экология, распространение, Баренцево море, канонический анализ соответствия.

\section{Z.Yu. Rumiantseva1, I.O. Nekhaev²}

${ }^{1}$ Murmansk Marine Biological Institute RAS, Murmansk, Russia

2St. Petersburg State University, St. Petersburg, Russia

\section{DISTRIBUTION OF SHELL GASTROPODS IN THE OPEN PARTS OF THE BARENTS SEA: A PRELIMINARY ANALYSIS}

\section{Abstract}

Species composition and distribution of shell-bearing gastropods in the Barents Sea has been described only for coastal regions. We used material from 247 stations (530 samples) remoted from the coast. In some cases, the distribution of mollusks depended on the type of substrate, and in others, only geographic location was 
revealed. The latter is probably due to hydrological factors or the presence of historically formed faunal complexes. The use of different approaches to the removal of uninformative samples during analysis gives similar results.

Keywords: Gastropoda, ecology, distribution, the Barents Sea, canonical correspondence analysis.

Введение. Брюхоногие моллюски редко вносят значимый вклад в количественные характеристики донной фауны, собираемой при помощи дночерпателей. По этой причине данные по распределению брюхоногих моллюсков в Баренцевом море практически отсутствуют в работах, посвященных описанию донных сообществ. Специальные работы, посвященные видовому составу и биотопическому распределению видовых комплексов Gastropoda, имеются только для прибрежных районов Баренцева моря (побережье Мурмана, Земля Франца-Иосифа, Новая Земля). Показано, что на распространение моллюсков вдоль побережий большое влияние оказывает наличие водной растительности, глубина, тип грунта и наличие распреснения.

В конце XIX века стали проводится систематические исследования фауны на стандартном разрезе "Кольский меридиан”. К.М. Дерюгиным (1924) были обобщены первые данные мониторинговых исследований на разрезе. В его работе подробно изложены результаты наблюдений за сменой гидрологических параметров, а также приведены видовые списки гидробионтов на каждой станции. В дальнейшем сведения о фауне и распределении раковинных Gastropoda на разрезе были дополнены на основании изучения сборов 1995-2013 гг. (Нехаев, Любин, 2016) и музейных коллекций (Nekhaev, Merkuliev, 2021). Разрез “Кольский меридиан" к настоящему времени является единственным удаленным от побережья районом Баренцева моря, для которого присутствуют сведения о фауне и распространении Gastropoda.

Дополнительная информация о находках раковинных Gastropoda в Баренцевом море приведена в монографиях из серии "Определители по фауне СССР”, изданных Зоологическим институтом АН СССР, “Фауна СССР” и других, более частных таксономических работах, в которых часто приводятся карты находок. К сожалению, такие сведения доступны только для сравнительно небольшого числа таксонов, а использование опубликованных карт для анализа распространения видов - затруднительно. Таким образом, к настоящему времени актуальным является выявление видового состава и общих закономерностей распространения раковинных брюхоногих моллюсков в открытых частях Баренцева моря, а также определение методических подходов и направлений для дальнейших исследований.

Одним из наиболее информативных типов анализа, который позволил бы сравнительно просто выявить наиболее общие закономерности распространения и выдвинуть гипотезы для последующих работ, служит канонических анализ соответствий - многомерный метод для определения 
отношений между сообществами биологических видов и средой их обитания. Метод предназначен для извлечения искусственных факторов окружающей среды из наборов экологических данных (Braak, Verdonschot, 1995).

В современных исследованиях данные, с которыми работают морские биологи, содержат большое число малоинформативных проб, что порождает проблему поиска ошибок и фильтрации данных. Однако применение слишком строгих критериев для исключения данных может привести к тому, что оставшегося материала может не хватить для анализа. Очень часто в экологии фильтрацию данных осуществляют по произвольно выбранным критериям, а оценка влияния самого процесса отбора данных на конечный результат исследования не проводится.

Цель настоящей работы - предварительный анализ распространения раковинных брюхоногих моллюсков в открытой части Баренцева моря с использованием канонического анализа соответствий. В ходе работы были решены две задачи: 1) выявление наиболее общих тенденций в распространении Gastropoda в исследуемом регионе; 2) сравнение результатов анализа при повышении строгости отбора данных.

Материал и методы. Работа основана на материалах, собранных в открытых частях Баренцева моря в ходе экспедиций ММБИ КНЦ РАН в 2015-2019 гг. Всего было обработано 530 проб с 247 станций (рис. 1).

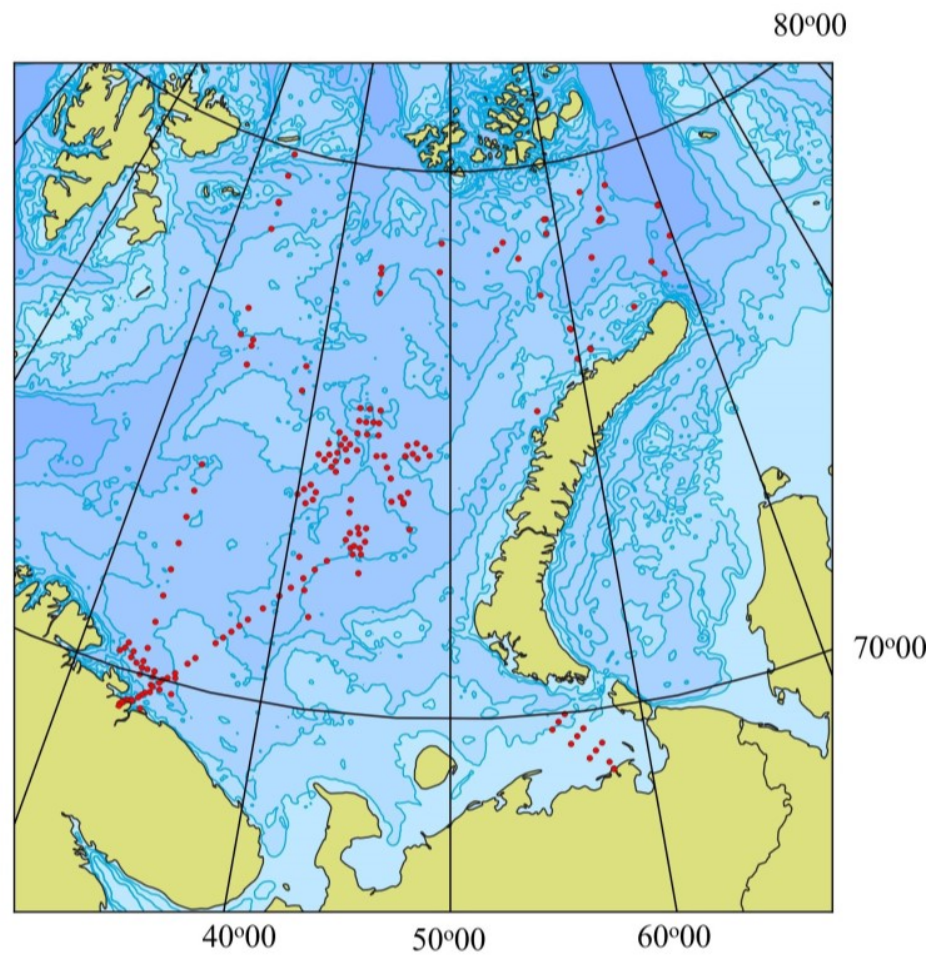

Рис. 1. Карта-схема расположения станций отбора проб Fig. 1. Map-scheme of benthic sampling 
Количественные пробы зообентоса в указанных экспедициях были отобраны при помощи дночерпателя ван-Вина с площадью захвата $0.1 \mathrm{~m}^{2}$ в 3- или 5-кратной повторности, промывались через капроновое сито с ячеей 0.5 мм и фиксировались $4 \%$-м раствором формальдегида, нейтрализованным тетраборатом натрия. В условиях стационарной лаборатории проводилась первичная сортировка проб вручную, также использовали стереомикроскоп. Определение моллюсков осуществлялось нами преимущественно по признакам раковины.

Для анализа в качестве независимых переменных были использованы глубина, географические координаты (широта и долгота) и характер грунта. Для описания грунта были выделены наиболее часто встречающиеся типа субстратов - ил, песок, глина, камни.

В ходе исследований выполнен анализ:

1) с использованием всего массива полученных данных (рис. 2А);

2) с удалением информации о станциях, на которых встречался только один вид брюхоногих моллюсков (рис. 2Б);

3) с удалением информации о станциях, на которых встречались один-два вида брюхоногих моллюсков (рис. 2В);

с удалением видов, которые встречались менее чем на пяти станциях (рис. 2Г).

Статистический анализ был выполнен в программе Past ver. 4.

Результаты и обсуждение. В результате исследования было идентифицировано 65 видов раковинных брюхоногих моллюсков. Чаще всего встречались 8 видов: Cryptonatica affinis (Gmelin, 1791), Cylichna alba (T. Brown, 1827), Euspira pallida (Broderip et G.B. Sowerby I, 1829), Frigidoalvania cruenta (Odhner, 1915), Frigidoalvania janmayeni (Friele, 1878), Laona quadrata (S. Wood, 1839). Также в северо-восточной части Баренцева моря (севернее арх. Новая Земля) на глубине 340 м были обнаружены 3 экз., соответствующие по раковине виду Onoba aculeus (Gould, 1841), достоверно известному только из прибрежных районов юго-западной части Баренцева моря.

Результаты проведенного канонического анализа соответствий приведены на рис. 2. В центре графика образуют ядро виды, имеющие достаточно широкий диапазон толерантности к факторам среды и встречающиеся практически повсеместно. Остальные виды условно можно разделить на две группы. Распределение первой из них в большей степени связано с типом грунта. Связь с грунтом сама по себе не означает непосредственное его влияние на распределение улиток. Грунт, как и глубина, не является обособленным фактором, потому что с ним прямо или косвенно связан комплекс других, например, наличие и характер придонных течений и температура. 


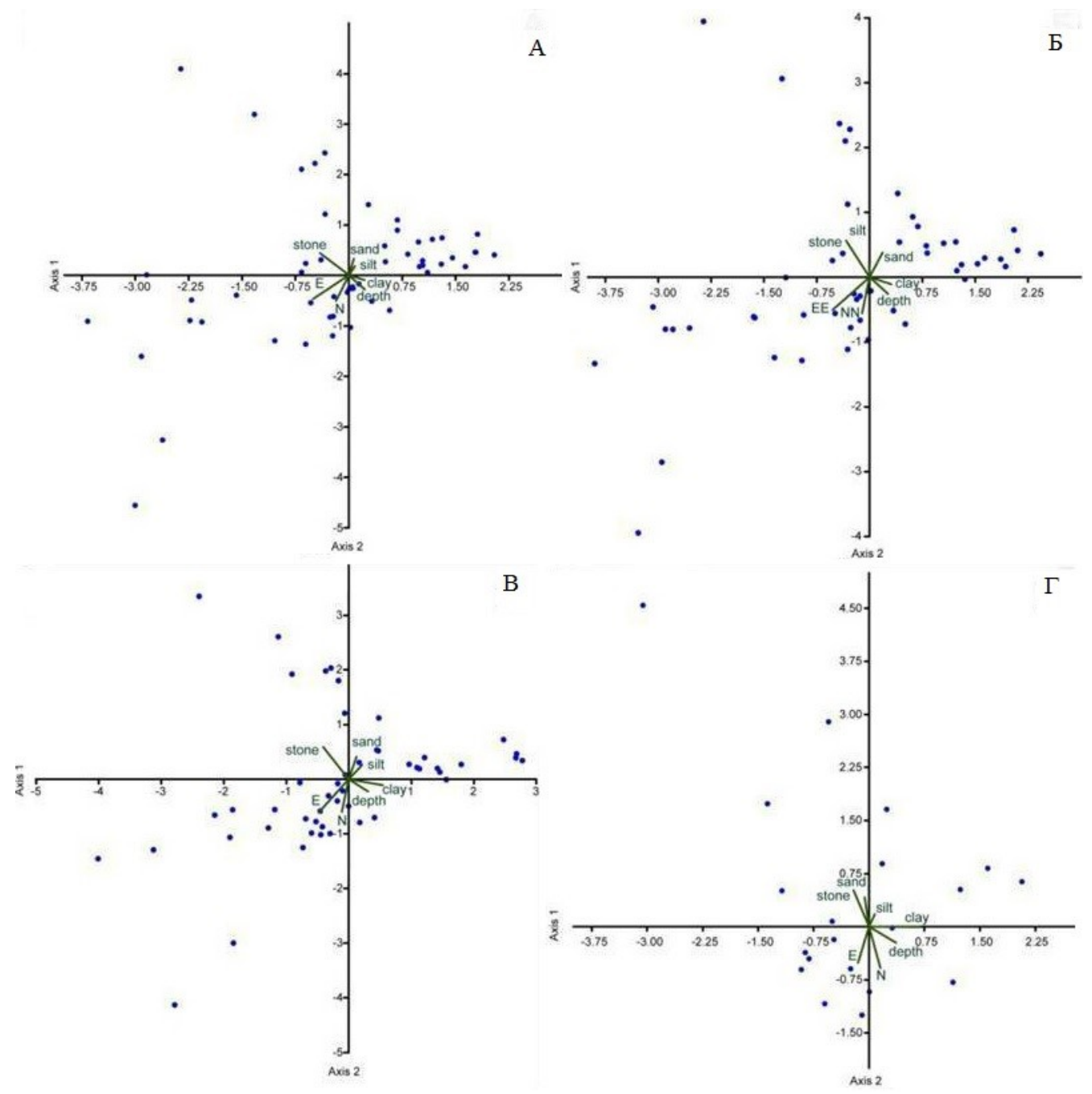

Рис. 2. Результаты канонического анализа соответствий. Пояснение в тексте

Fig. 2. Results of canonical conformity analysis. Explanation in the text

Распределение второй группы видов оказалось в меньшей степени связано с типом субстрата и в большей степени приурочено к переменным, которые описывают пространственное распространение (географическое положение и глубину) и не являются непосредственно средовыми факторами. Корреляция с пространственными переменными может отражать зависимость от факторов, которые имеют четкий географический градиент. К таким факторам может относиться гидрологический режим, который признается основной причиной неоднородности населения Баренцева моря (Дерюгин, 1924). Это может обусловливать, например, наличие группы видов, приуроченной к южной части разреза “Кольский меридиан” и находящейся в зоне влияния 
теплых вод Северо-Атлантического течения. К таким видам относятся Aclis sarsi (Dautzenberg et H. Fischer, 1912), Haliella stenostoma (Jeffreys, 1858) и некоторые другие. Альтернативной причиной пространственной неоднородности может быть наличие в регионе нескольких исторически сложившихся биогеографических регионов (Филатова, 1957; Jirkov, 2013). В частности, некоторые глубоководные таксоны [например, Cerithiella danielsseni (Friele, 1877) и Admete contabulata (Friele, 1879)] в ходе текущего и предшествующих исследований были обнаружены на шельфе на северо-востоке Баренцева моря (Фауна ..., 2017; Nekhaev, 2018).

Во всех четырех вариантах анализа расположение видов относительно векторов с обозначением абиотических факторов остается очень схожим. Небольшие отличия были выявлены в расположении векторов “silt” (ил) и “clay" (глина).

Наши данные показали, что станции с небольшим числом находок и редкие виды не влияют существенно на результат анализа, что может свидетельствовать о высокой достоверности выводов.

\section{Литература}

Дерюгин К.М. Баренцево море по Кольскому меридиану $30^{\circ} 30^{\prime}$ в. д. // Тр. Северной науч.-промысл. экспедиции. 1924. Вып. 19. 102 с.

Нехаев И.О., Любин П.А. Брюхоногие и лопатоногие моллюски на гидробиологическом разрезе “Кольский меридиан" // Тр. Кольского науч. центра РАН. 2016. Т. 2(36). Сер. Океанология. Вып. 3. С. 232-245.

Фауна и количественное распределение зообентоса в северной части Баренцева моря в апреле-мае 2016 года / О.Л. Зимина, Е.А. Фролова, Д.Р. Дикаева и др. // Тр. Кольского науч. центра РАН. 2017. Т. 2(8). Сер. Океанология. Вып. 4. C. $66-80$.

Филатова 3.А. Зоогеографическое районирование северных морей по распространению двустворчатых моллюсков // Тр. Ин-та океанологии АН CCCP. 1957. T. 23. C. 195-215.

Braak C.J.E., Verdonschot P.E.M. Canonical correspondence analysis and related multivariate methods in aquatic ecology // Aquatic Sci. 1995. Vol. 57/3. P. 255-289.

Jirkov I.A. Biogeography of the Barents Sea benthos // Invertebrate Zoology. 2013. Vol. 10(1). P. 69-88.

Nekhaev I.O. Distribution of Admete contabulata and Iphinopsis inflata in the Arctic (Gastropoda: Cancellariidae) // Ruthenica. 2018. Vol. 28, № 4. P. 163-168.

Nekhaev I.O., Merkuliev A.V. Missing and misidentified museum specimens hinder long-term monitoring: a case study of shell-bearing gastropods from the Kola Meridian transect, Barents Sea // Polar Research. 2021. Vol. 40. P. 1-6. 
DOI: $10.37614 / 2307-5252.2021 .3 .9 .017$

УДК $574.5(268.45)$

\section{О.В. Смолькова}

Мурманский морской биологический институт РАН, г. Мурманск, Россия

\section{ПРОДУКЦИОННЫЕ ХАРАКТЕРИСТИКИ ПОСЕЛЕНИЙ ДВУСТВОРЧАТОГО МОЛЛЮСКА МYA ARENARIA LINNE, 1758 БАРЕНЦЕВА МОРЯ}

\section{Аннотация}

Изучены особенности линейного роста и рассчитана продукция поселений двустворчатого моллюска Mya arenaria (Linne, 1758) на литорали губ Ярнышная и Зеленецкая Баренцева моря. Размеры моллюсков в исследованных районах варьировали от 26.3 до 62.5 мм, максимальный возраст составлял $11+$ лет. Показатели темпа роста моллюсков в губе Зеленецкая заметно выше, чем в губе Ярнышная. Линейный рост моллюсков в губах описывается уравнениями Берталанфи: $L_{t}=84.27\left[1-e^{-0.0721}(\mathrm{t}-0.1244)\right]-$ Ярнышная, $L_{t}=118.49\left[1-e^{-0.0566}(t-0.2744)\right]-$ Зеленецкая. Продукция на литорали губы Ярнышная ниже $\left(44.8 \mathrm{r} / \mathrm{m}^{2}\right.$ при биомассе $\left.330 \mathrm{r} / \mathrm{M}^{2}\right)$, чем на литорали губы Зеленецкая $\left(90.5 \mathrm{r} / \mathrm{m}^{2}\right.$, при биомассе 258 r/M²), Р/В-коэфффициент - 0.14 и 0.35 соответственно.

Ключевые слова: двустворчатые моллюски, Муа arenaria, литораль, линейный рост, размерный и возрастной состав, продукция, Р/B-коэфффициент, Баренцево море.

\section{O.V. Smolkova}

Murmansk Marine Biological Institute RAS, Murmansk, Russia

\section{PRODUCTION CHARACTERISTICS OF SETTLEMENTS BIVALVE MYA ARENARIA LINNE, 1758 OF THE BARENTS SEA}

\section{Abstract}

The linear growth equations and production for bivalve Mya arenaria (Linne, 1758) in the intertidal zone Yarnyshnaya and Zelenetskaya bays of Barents Sea are represented. Our studies have shown that length of the shell Mya reached 26.3-62.5 mm, the highest age was 11 years. Indicators of the growth rate of mollusks from Zelenetskaya Bay are significantly higher than those of mollusks from Yarnyshnaya Bay. Linear growth is described by the Bertalanfi equations: $L_{t}=84.27\left[1-e^{-0.0721}(t-0.1244)\right]-$ for mollusks from Yarnyshnaya Bay, $L_{t}=118.49\left[1-e^{-0.0566}(t-0.2744)\right]$ - for mollusks from Zelenetskaya Bay. Production in the intertidal zone of the Yarnyshnaya Bay was lower $\left(44.8 \mathrm{~g} / \mathrm{m}^{2}\right.$ with a biomass of $\left.330 \mathrm{~g} / \mathrm{m}^{2}\right)$ than in the intertidal zone of the Zelenetskaya Bay $\left(90.5 \mathrm{~g} / \mathrm{m}^{2}\right.$, with a biomass of $\left.258 \mathrm{~g} / \mathrm{m}^{2}\right)$. The $P N$-value is the coefficient of 0.14 and 0.35 , respectively.

Keywords: Bivalvia, Mya arenaria, intertidal zone, growth, size and age composition, production, $P /$-value, Barents Sea.

Введение. Литораль приливных морей Арктики представляет собой протяженную экологическую зону морского дна, характеризующуюся изменчивыми условиями среды. На литорали сила воздействия природных 
факторов на донных беспозвоночных достигает максимальных значений, что, несомненно, находит отражение в характере основных жизненных стратегий видов, обитающих здесь. Высокая степень изменений условий среды влияет на процессы роста организмов, питание, дыхание, скорость протекания метаболизма и др. Одним из видов, приспособившихся к жизни в таких условиях, является двустворчатый моллюск Mya arenaria Linne, 1758. Mya arenaria (песчаная ракушка) - крупный двустворчатый моллюск, зарывающийся в илистый или илисто-песчаный грунт на глубину до 40-50 см (Свешников, 1963; Pfitzenmeyer, 1967). Связь с поверхностью грунта моллюск поддерживает с помощью сифона толстой кожистой трубки, образованной двумя сросшимися сифонами: вводным и выводным. Изучение особенностей биологии, закономерностей роста Mya arenaria представляет большой интерес. Высокая степень эврибионтности делает Mya arenaria перспективным видом для оценки влияния климатических изменений на природную среду Арктики, для прогнозирования поведения более редких видов, менее доступных исследователям. Получение новых данных об особенностях биологии Mya arenaria важно с практической точки зрения, поскольку связано с вопросами развития марикультуры, рационального использования природных ресурсов, оценки антропогенной нагрузки на морские бентосные сообщества.

Цель исследований - изучить особенности линейного роста двустворчатого моллюска Mya arenaria в условиях Баренцева моря, оценить влияние абиотических факторов на темпы роста моллюсков, рассчитать продукционный потенциал.

Материал и методы. Материал был собран в августе 2009 г. на литорали Баренцева моря. Для исследования было выбрано два участка губа Ярнышная (кут), губа Зеленецкая (Дальний пляж) (рис. 1).

Пробы отбирали на литорали во время отлива с площади $0.1 \mathrm{~m}^{2}$. Длину раковины и величину годовых приростов измеряли с помощью штангенциркуля с точностью 0.1 мм, возраст определяли подсчетом годичных колец, образующихся при зимней остановке роста и представляющих собой утолщенные линии нарастания. Характер линейного роста моллюсков в поселениях описан по групповым возрастным рядам, построенным по усредненным данным по каждой точке исследований. Линейный рост двустворчатого моллюска Mya arenaria Баренцева моря аппроксимирован с помощью уравнения Берталанфи (Мельникова, 2009)

$$
L_{\mathrm{t}}=L_{\infty}\left[1-e^{k\left(t-t_{0}\right)}\right]
$$

где $L_{\mathrm{t}}$ - длина раковины моллюска в возрасте $t ; L_{\infty}-$ асимптотическая (предельная) длина раковины моллюска; $k$ - коэффициент, характеризующий теоретический возраст, при котором длина моллюска равна нулю; $t_{0}-$ возраст, который соответствует длине моллюска, равной нулю. 


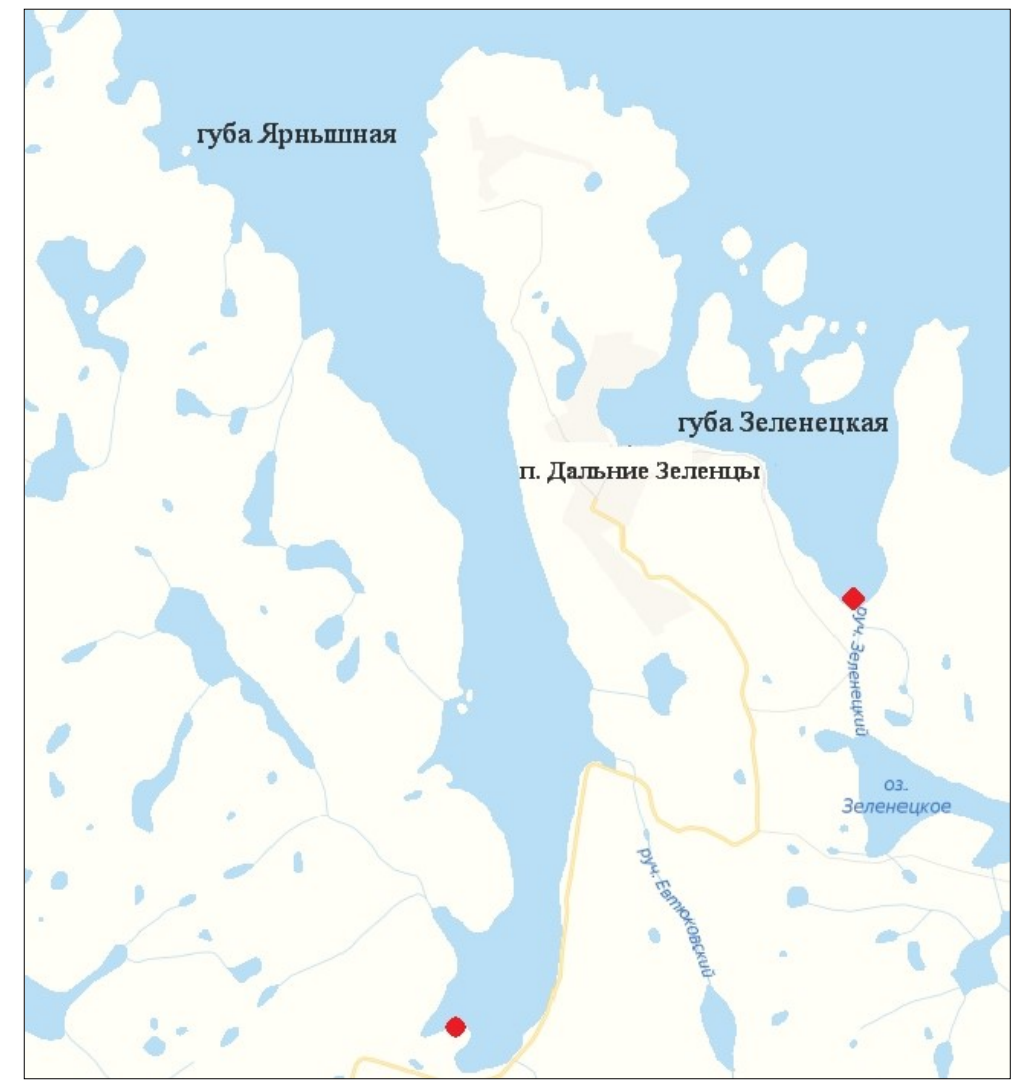

Рис. 1. Карта-схема районов исследований

Fig. 1. Area map

Для сопоставления характеристик роста Mya arenaria из разных районов применяли показатель $\varphi^{\prime}$, вычисляемый по формуле

$$
\varphi^{\prime}=2 \log _{10}\left(L_{\infty}\right)+\log _{10}(k) .
$$

Закономерности изменения массы моллюсков с возрастом определены по зависимости, связывающей сырую массу особей $W$ с длиной их раковины. В данном случае она имеет вид $W=0.0002 L^{2.9}$. Ее параметры найдены в результате измерений 54 особей. Численность моллюсков в возрастных группах оценена при прямом подсчете особей каждого возраста.

Продукцию моллюсков Mya arenaria рассчитывали по формуле для разовой выборки (Максимович, Погребов, 1986):

$$
P=\left(\frac{N_{t}+N_{t-1}}{2}\right)\left(W_{t}-W_{t-1}\right),
$$

где $N_{t}$ и $N_{t-1}$ - численность особей в возрасте $t$ и $t-1, W_{t}$ и $W_{t-1}-$ средняя масса особей в возрасте $t$ и $t-1$. 
Также определяли удельную продукцию ( $P / B$-коэффициент), величину продукции моллюсков в каждой возрастной группе, отнесенную к их средней биомассе за один и тот же отрезок времени.

Рассмотрена изменчивость максимальных размеров моллюсков $\left(L_{\max }\right)$, длины раковины в первую зимнюю остановку роста, ежегодного прироста длины раковины, предельной длины раковины $\left(L_{\infty}\right)$ в зависимости от протяженности литорали, типа губы, процентного содержания в грунте фракций с размером частиц менее 0.25 мм. Механический состав грунта определяли с помощью набора почвенных сит с размером ячеи 10, 5, $2,1,0.5,0.25$ мм. Измеряли температуру и соленость морской воды. Линейную корреляционную зависимость определяли с использованием непараметрического коэффициента корреляции Спирмена $(r)$.

Количественные и размерные показатели имеют распределение отличное от нормального (оценка по критерию Колмогорова-Смирнова), поэтому обработку данных проводили с использованием непараметрических методов статистической обработки, для этого рассчитывали медиану $(\mathrm{Me})$ длины, годовых приростов, определяли ошибку $(m)$ и коэффициент вариации $(C V, \%)$. Достоверность отличий определена с помощью $U$-критерия Манна-Уитни $(p<0.05)$.

Математические расчеты проведены с использованием программного пакета STATISTICA 10.0.

Результаты и обсуждение. Локализация скоплений. Mya arenaria в губе Зеленецкая обитает в юго-восточной части на илисто-песчаной литорали (табл. 1). Литораль достаточно пологая, имеет протяженность до 200 м в кутовой части. Соленость в течение года держится сравнительно высокой и составляет в среднем от 32-34 \%о. Распресняющее действие ручья, впадающего в кут, незначительно (Пригоровский, 1948). Моллюски здесь сосредоточены преимущественно в среднем и нижнем горизонтах литорали (плотность поселения 35 экз/ $\mathrm{M}^{2}$ ) и приурочены главным образом к грунту с превалирующим содержанием мелкодисперсных глинистых фракций с размером частиц менее 0.25 мм (более $50 \%$ ).

В губе Ярнышная Mya arenaria имеет ограниченное распространение и встречается только в кутовой части на илистом грунте с примесью гравия, гальки и ракушки (Шаронов, 1948; Сорокин, Пельтихина, 1991). Литораль пологая, имеет протяженность до 300 м в кутовой части. Соленость при движении с севера на юг изменяется (Матвеева, 1948). В северной части соленость нормальная (33 \%), к югу она уменьшается и в куту достигает 19 \% из-за распресняющего действия ручья, впадающего в вершину кута. Плотность поселения на этом участке достигает 32 экз/м², биомасса 330 г/м² (табл. 1$)$. 
Т а бли ца 1

\section{Гидрологическая характеристика исследованных районов,} численность и биомасса Mya arenaria

Table 1

\section{Hydrological characteristics of the study areas, abundance and biomass of Mya arenaria}

\begin{tabular}{l|c|c}
\hline \multicolumn{1}{c|}{ Параметр } & Губа Ярнышная & Губа Зеленецкая \\
\hline Тип губа & Открытая & Закрытая \\
Протяженность литорали, м & 300 & 200 \\
Гранулометрический состав & Размер частиц 0.25 мм & Размер частиц 0.25 мм \\
грунта & и более $-29.0 \%$, & и более $-50.4 \%$, \\
& $<0.25$ мм $-71.0 \%$ & $<0.25$ мм $-49.6 \%$ \\
Преобладающий тип грунта & Илистый & Илисто-песчаный \\
Плотность поселения, экз $/ \mathrm{m}^{2}$ & 32.5 & 35.0 \\
Биомасса, г $/ \mathrm{m}^{2}$ & 329.9 & 258.0 \\
Соленость воды, \%о & 19.0 & 32.0 \\
Температура воды, ${ }^{\circ} \mathrm{C}$ & 10.0 & 12.0
\end{tabular}

Размерно-возрастной состав поселений. Размеры моллюсков Mya arenaria в исследованных районах варьировали от 26.3 до 62.5 мм (рис. 2). В губе Ярнышная отмечено два пика распределения моллюсков по длине раковины: 1) 30.0-39.9 мм (47.8 \%), 2) 40.0-49.9 мм (39.1\%). При этом доля особей с длиной более 60 мм составляла $4.3 \%$. В губе Зеленецкая моллюски в целом были мельче, при этом особи с длиной раковины 20.0-29.9 мм составляли 33.3\%, а с длиной 30.0-39.9 мм $37.0 \%$.

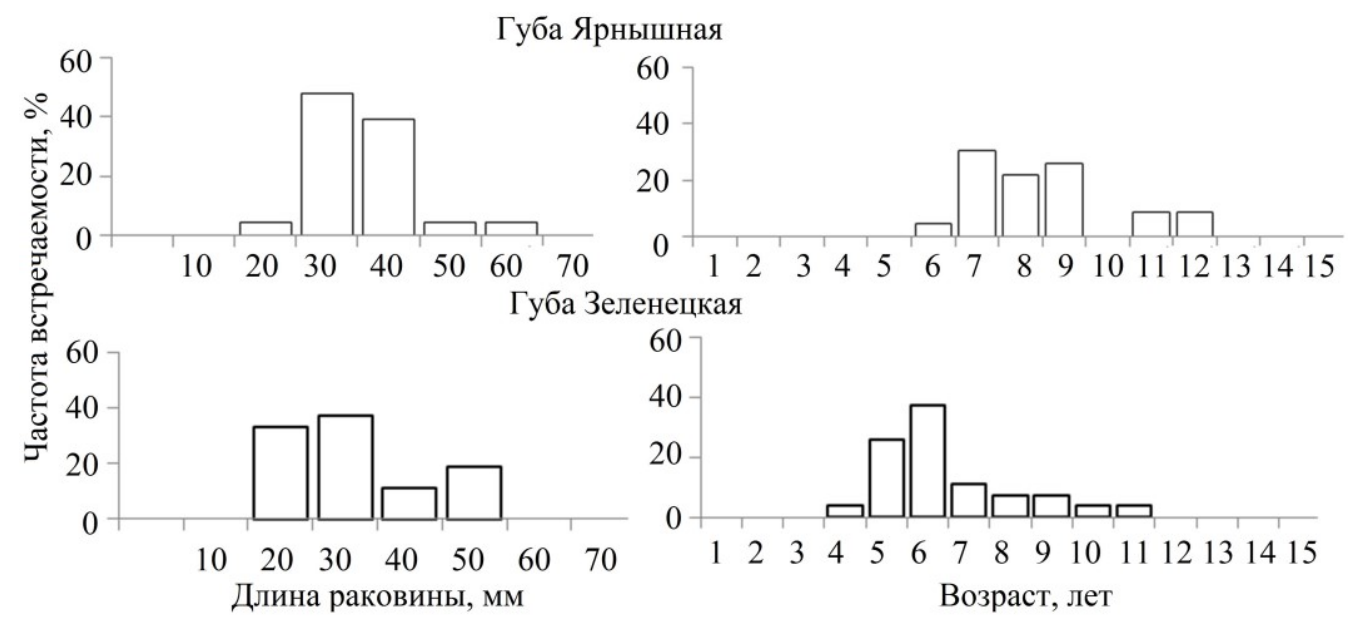

Рис. 2. Размерный (слева) и возрастной (справа) состав поселений $М у а$ arenaria на литорали губ Ярнышная и Зеленецкая

Fig. 2. Shell length (left) and age composition (right) of the Mya arenaria settlements in the intertidal zone Yarnyshnaya and Zelenetskaya bays 
Возрастной состав моллюсков на исследованных участках отличался незначительно (рис. 2). В губе Ярнышная возраст Mya arenaria составлял 5-11 лет. Доминировали особи в возрасте 7 (30.4\%), 8 (21.7\%) и 9 (26.1\%) лет, доля 5-летних - $7.7 \%$, а в возрасте 6 и 11 лет моллюски отмечены единично (по $3.8 \%$ соответственно). Особи в возрасте 10 лет отсутствовали. На литорали губы Зеленецкая возрастной ряд был несколько более широким - от 4 до 11 лет. При этом доминировали моллюски 5-6 лет (60.7\%), особи в возрасте 7-9 лет составили $28.5 \%$. Единично были зарегистрированы моллюски в возрасте 4, 10 и 11 лет (по $3.6 \%$ соответственно).

Моллюски младших возрастных групп (1-2 года) нами в пробах не зарегистрированы. Данное явление характерно для поселений Муa arenaria и возникает вследствие различий режима пополнения молодью, внутривидовой и межвидовой конкуренции, гибели моллюсков на ранних стадиях развития (Герасимова, Максимович, 2009). По данным нашей выборки можно предположить, что наиболее благоприятными для пополнения поселений Mya arenaria в исследованных районах были 2003-2005 гг.

Линейный рост и продукция. Рост Муа arenaria описывается уравнениями (рис. 3)

$L_{\mathrm{t}}=84.27\left[1-e^{-0.0721(t-0.1244)}\right]-$ губа Ярнышная,

$L_{\mathrm{t}}=118.49\left[1-e^{-0.0566(t-0.2744)}\right]-$ губа Зеленецкая.

В изученных поселениях Mya arenaria отмечено более интенсивное увеличение длины раковины в первые годы жизни (1-3 года). Средний

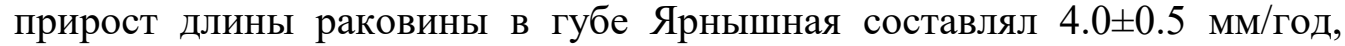
максимальный -10.1 мм/год (между третьим и четвертым годами жизни),

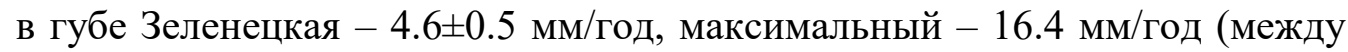
третьей и четвертой зимними остановками роста). Средние размеры моллюсков в первую зимнюю остановку роста в губе Ярнышная соответствовали 5.2 мм, в губе Зеленецкая - 4.8 мм. С увеличением возраста темп роста заметно снижался, и у моллюсков в возрасте 8 лет средний прирост не превышал 3.5 мм/год.

Анализ коэффициентов уравнений роста позволил определить характер и направленность роста моллюсков Mya arenaria. Моллюски в губе Зеленецкая имеют более высокие значения предельной длины раковины $\left(L_{\infty}\right)$, чем моллюски из губы Ярнышная. Константа замедления роста $(k)$ выше в губе Ярнышная (табл. 2). Показатель $\varphi^{\prime}$, используемый для сравнения характеристик роста, выше у моллюсков в губе Зеленецкая, следовательно, моллюски в ней растут и достигают своих предельных размеров гораздо быстрее, чем в условиях губы Ярнышная. Данный показатель подчеркивает влияние факторов окружающей среды на темпы роста и максимальные размеры тела 

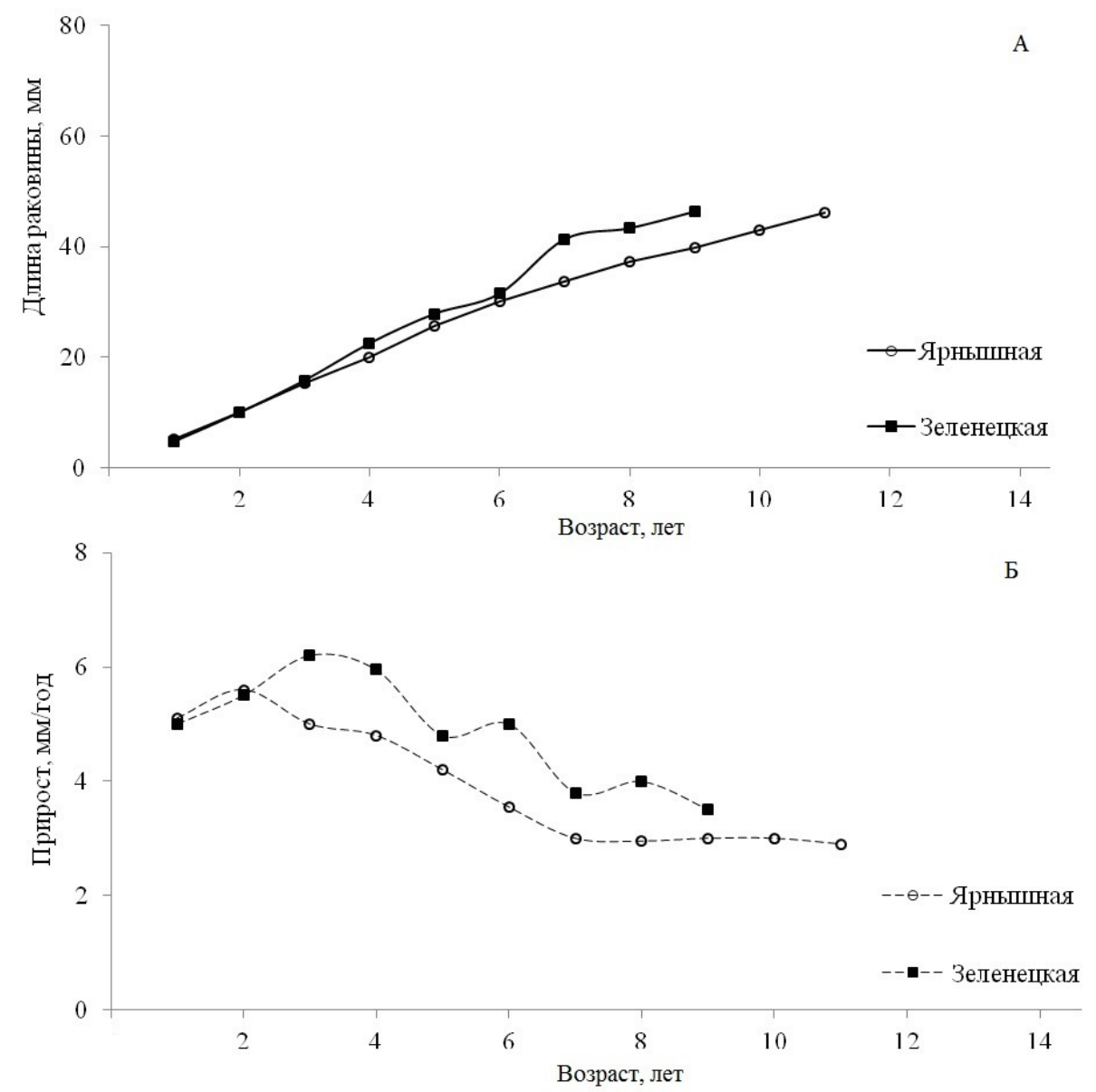

Рис. 3. Возрастные изменения длины раковины (А) и ежегодный прирост (Б) моллюсков Mya arenaria в губах Восточного Мурмана (Баренцево море)

Fig. 3. Age variation of shell length (A) and annual increment (Б) of mollusks Mya arenaria of the Eastern Murman (Barents Sea)

Т а бли ц а 2

Показатели линейного роста Mya arenaria в исследованных районах Баренцева моря

Indicators of linear growth of Mya arenaria

$\mathrm{Table} 2$ in the studied areas of the Barents Sea

\begin{tabular}{ccc}
\hline Параметры & Губа Ярнышная & Губа Зеленецкая \\
\hline уравнения Берталанфи & 84.27 & 118.49 \\
$L_{\infty}$ & 0.072 & 0.057 \\
$t_{0}$ & 0.12 & 0.27 \\
$\varphi^{\prime}$ & 2.71 & 2.90
\end{tabular}

ПРИМЕЧАНИЕ. $L_{\infty}-$ асимптотическая (предельная) длина раковины моллюска; $k$ - коэффициент возрастного замедления скорости роста моллюска; $t_{0}-$ возраст, который соответствует длине моллюска, равной нулю. 
Анализ гранулометрического состава грунта показал, что местообитания моллюсков отличаются по содержанию мелкодисперсных фракций. В губе Зеленецкая преобладающим является илисто-песчаный тип грунта с содержанием частиц размером менее 0.25 мм от 49.6 до $60.3 \%$ (табл. 1). Моллюски имели здесь наибольшие значения теоретически рассчитанной предельной длины раковины (табл. 2). В губе Ярнышная наблюдалось сильное заиление с содержанием мелких глинистых фракций $-71.0 \%$, и показатели линейного роста моллюсков здесь были значительно ниже, чем в губе Зеленецкая (табл. 2). В условиях протяженной литорали губы Ярнышная (более 200 м) моллюски длительное время поддерживают метаболизм (дыхание, питание) за счет остаточной воды в норке и имеют самые низкие показатели роста. Выявлены сильные корреляционные связи между гранулометрическим составом грунта и предельной длиной раковины моллюсков $(r=0.94)$, протяженностью литорали и константой замедления роста $(r=0.74)$. Таким образом, наиболее значимыми факторами, влияющими на линейный рост моллюсков в районах исследований, являются протяженность литорали и гранулометрический состав грунта.

Корреляция средних приростов моллюсков на втором, третьем и четвертом годах жизни с размерами особей в первую зимнюю остановку роста была слабой $(r=0.26, r=0.27, r=0.18$ соответственно), с размерами моллюсков в возрасте трех лет - средняя $(r=0.30-0.55)$.

Величина годовой продукции в губе Зеленецкая составила 90.5 г/м

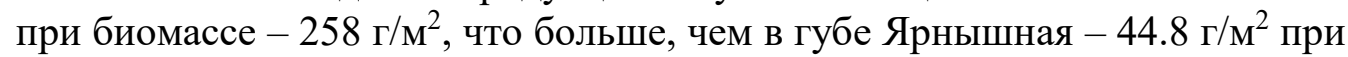
биомассе $330 \mathrm{r} / \mathrm{M}^{2}$. Значение $P / B$-коэффициента в изученных поселениях соответствует 0.35 и 0.14 .

Очевидно, что для бентосных организмов, ведущих неподвижный образ жизни, важным фактором является пищевой. Моллюски Mya arenaria находятся в грунте на глубине более 20 см, и главный механизм взаимодействия моллюсков с внешней средой - мускульный сифон. Сифон вытягивается к поверхности грунта для осуществления процессов питания, дыхания, обмена веществ, и моллюску требуются много энергии именно для поддержания его функций. Основной процесс получения энергии - питание, который, несомненно, сопряжен с гидрологическими условиями мест обитания моллюсков. Поэтому на годовой прирост биомассы Mya arenaria оказывают влияние разные гидрологические условия исследованных районов (табл. 1).

Исходя из сказанного выше и анализируя темп роста и показатели продуктивности поселений двух исследованных районов, можно предположить, что обеспеченность пищей моллюсков в губе Зеленецкая (Дальний пляж) должна быть лучше. В губу впадает ручей, который практически не оказывает влияния на соленость, но, вероятно, выносит достаточное для активного питания и роста количество взвешенного 
органического вещества. В данном местообитании моллюски растут быстрее. В губе Ярнышная моллюски растут и набирают массу гораздо медленнее. Кутовая часть губы представляет собой обширный илистопесчаный пляж, который удален от открытого моря, характеризуется значительными колебаниями солености в течение года, что в целом выражается в снижении темпов роста моллюсков. Кроме этого, впадающий в кутовую часть ручей имеет довольно глубокий желоб и, возможно, большая часть взвешенного органического вещества выносится за пределы местообитания Mya arenaria.

Заключение. Наши исследования показали, что различия размерновозрастных показателей, обилия, темпов роста моллюсков взаимосвязаны с особенностями природных условий конкретных местообитаний. Выявлена четкая зависимость темпов роста M. arenaria от состава грунта и протяженности литорали. В поселениях на литорали протяженностью не более 200 м и в грунте с превалирующим содержанием мелкодисперсных глинистых фракций моллюски растут интенсивнее. На годовой прирост биомассы Mya arenaria оказывают влияние разные гидрологические условия исследованных районов.

Работа выполнена по теме 9-19-01 “Донные сообщества Баренцева моря, его водосборного бассейна и сопредельных вод: экология, биоразнообразие, роль чужеродных видов" в рамках государственного задания (№ 0228-2019-0025) и при финансовой поддержке проекта "Морфологические и физиологические аспекты видообразования и формирования адаптационных стратегий видов в прибрежных экосистемах приливных морей Голарктики и Арктики” (№ 3832) в рамках АВЦП "Развитие научного потенциала высшей школы".

\section{Литература}

Герасимова А.В., Максимович Н.В. О закономерностях организации поселений массовых видов двустворчатых моллюсков Белого моря // Вестн. СПбГУ. 2009. Сер. 3, вып. 3. С. 82-97.

Максимович Н.В., Погребов В.В. Анализ количественных гидробиологических материалов. Учеб. пособие. Л.: Изд-во Ленингр. гос. ун-та, 1986. 97 с.

Матвеева T.A. Сезонные изменения литорального населения на каменистой фации в губе Дальне-Зеленецкой // Тр. Мурм. биол. ст. АН СССР. 1948. Т. 1. C. $123-145$.

Мельникова Е.Б. Определение коэффициентов уравнения роста Берталанфи при отсутствии регулярных измерений // Биологические ресурсы Белого моря и внутренних водоемов европейского Севера: Матер. XXVIII Междунар. конф., 5-8 октября 2009 г. Петрозаводск: Изд-во КарНЦ РАН, 2009. С. 353-356.

Пригоровский Б.Г. Фауна мягких грунтов литорали губы ДальнеЗеленецкой // Тр. Мурм. биол. ст. АН СССР. 1948. Т. 1. С. 146-155.

Свешников B.A. Биоценотипические связи и условия существования некоторых кормовых беспозвоночных инфауны литорали Кандалакшского залива Белого моря // Тр. Кандалакшского гос. заповедника. Вып. IV, № 2; Тр. ББС МГУ. 1963. Т. II. С. 114-134. 
Сорокин А.Л., Пельтихина Т.С. Ламинариевые водоросли Баренцева моря. Мурманск: Изд-во ПИНРО, 1991. 187 с.

Шаронов И.В. Сублиторальные бентосные группировки бухты Ярнышной // Тр. Мурм. биол. ст. АН СССР. 1948. Т. 1. С. 155-169.

Pritzenmeyer H.T. Benthic survey for population of softshell clam Mya arenaria, in the Lower Potomac River, Maryland // Chesapeake Sci. 1963. Vol 4, № 2. P. 67-74.

Pritzenmeyer H.T. Some factors influencing ribburroving acnivity of softshell clam Mya arenaria // Chesapeake Sci. 1967. Vol. 8, № 3. P. 195-199.

DOI: $10.37614 / 2307-5252.2021 .3 .9 .018$

УДК 597.5:591.9

C.A. Чаус

Мурманский морской биологический институт РАН, г. Мурманск, Россия

ПРОСТРАНСТВЕННОЕ РАСПРЕДЕЛЕНИЕ ICELUS BICORNIS

(REINHARDT, 1840) И ICELUS SPATULA GILBERT \& BURKE, 1912

B MOРЯХ РОССИЙСКОЙ АРКТИКИ

Аннотация

В работе приводятся данные о распределении циркумполярных видов арктического двурогого ицела Icelus bicornis и восточного двурогого ицела Icelus spatula в морях российской Арктики (Баренцево, Карское, Лаптевых, ВосточноСибирское) с 2014 по 2019 гг. Численность арктического двурогого ицела варьировала от 2 до 18 экз/км², а биомасса в пределах 0.002-0.089 кг/км². Для восточного двурогого ицела эти показатели составляли 2-21 экз/км² и $0.002-$ $0.699 \mathrm{kг} / \mathrm{kм}^{2}$ соответственно. Максимальные и минимальные значения этих показателей для Icelus bicornis отмечены в море Лаптевых, а для Icelus spatula в Восточно-Сибирском море. Также приведены сведения по вертикальному пространственному распределению видов, подтверждающие приведенную ранее информацию о том, что в отличие от арктического двурогого ицела, восточный двурогий ицел встречается на меньших глубинах.

Ключевые слова: арктический двурогий ицел Icelus bicornis, восточный двурогий ицел Icelus spatula, пространственное распределение.

S.A. Chaus

Murmansk Marine Biological Institute RAS, Murmansk, Russia

SPATIAL DISTRIBUTION OF ICELUS BICORNIS (REINHARDT, 1840) AND ICELUS SPATULA GILBERT \& BURKE, 1912 IN THE RUSSIAN ARCTIC SEAS

\footnotetext{
Abstract

This article provides data on distribution of two circumpolar species - twohorn sculpin Icelus bicornis and spatulate sculpin Icelus spatula in the Russian Arctic seas (Barents
} 
Sea, Kara Sea, Laptev Sea, East Siberian Sea) in the period from 2014 to 2019. The abundance of the twohorn sculpin varied from 2 to $18 \mathrm{ind} / \mathrm{km}^{2}$, and the biomass varied within $0.002-0.089 \mathrm{~kg} / \mathrm{km}^{2}$. For the spatulate sculpin, these parameters were $2-21 \mathrm{ind} / \mathrm{km}^{2}$ and $0.002-0.699 \mathrm{~kg} / \mathrm{km}^{2}$. The maximum and minimum values of these parameters for Icelus bicornis were recorded in the Laptev Sea, and for Icelus spatula in the East Siberian Sea. Information on the vertical spatial distribution of these species is also given, confirming the information given earlier that the spatulate sculpin occurs at shallower depths in contrast to the twohorn sculpin.

Keywords: twohorn sculpin Icelus bicornis, spatulate sculpin Icelus spatula, spatial distribution.

Введение. Представители семейства рогатковых (Cottidae) - важный элемент ихтиофауны шельфа и материкового склона арктических морей (Андрияшев, 1954). Одними из обычных, но относительно малочисленных представителей семейства рогатковых в морях российской Арктики являются виды рода Icelus - арктический двурогий ицел Icelus bicornis (Reinhardt, 1840) и восточный двурогий ицел Icelus spatula Gilbert \& Burke, 1912. Оба вида циркумполярны и не образуют плотных скоплений (Jensen, Volsøe, 1949; Есипов, 1952; Андрияшев, 1954; McAllister, 1962; Nelson, 1984; Боркин, 1994; Неелов, Чернова, 1994, 2005; Byrkjedal, Høines, 2007; Боркин и др., 2008; Atlas ..., 2011).

В связи с изменяющимися условиями обитания организмов в арктических экосистемах требуется регулярное уточнение информации о современном состоянии популяций отдельных видов и возможном изменении их ареалов. Поэтому целью данной работы является обобщение данных о распределении двух представителей рода Icelus в морях российской Арктики.

Материал и методы. Использованный в работе материал был получен в экспедициях Мурманского морского биологического института в Баренцевом, Карском, Лаптевых и Восточно-Сибирском морях на НИС “Дальние Зеленцы” с 2014 по 2019 гг. Всего поймано 36 экз. Icelus bicornis и 42 особи Icelus spatula. Лов выполнялся донным тралом (чертеж № 2387) с ячеей 138 мм и мелкоячейной вставкой 12 мм. Горизонтальное раскрытие трала составляло 12-14 м, вертикальное - 3.5-4.5 м, скорость траления соответствовала 2.5-3.3 узла в течение 20-30 мин.

В мелководных районах, с глубинами менее 20 м, использовали трал Сигсби с длиной рамы 1 м, высотой $30 \mathrm{~cm}$ и сетным полотном с ячеей 7 мм. Продолжительность траления для этого орудия лова составляла 30 мин при скорости буксировки судна 1.5 узла. Обработка материала и видовая идентификация проводились по общепринятым ихтиологическим методикам (Правдин, 1966; Методическое ..., 1974; Инструкции ..., 2004).

Расчет плотности распределения рыб по биомассе (численности) (без учета коэффициента уловистости) проведен для каждой станции отдельно по формуле 


$$
B_{\mathrm{KT} / \mathrm{km} 2}\left(N_{\text {экз/км }}^{2}\right)=\frac{B(N)_{\text {ул }} \cdot 10^{6}}{D H}
$$

где $B(N)_{\text {ул }}$ - биомасса (численность) улова; $D=V t-$ путь, пройденный тралом со скоростью $V$ за время траления $t ; H$ - ширина раскрытия трала.

Результаты и обсуждение. Анализ собранных материалов показал, что все районы наших поимок для видов рода Icelus находятся в пределах ранее известного ареала их распространения (Marine ..., 2018). На обследованной акватории Баренцева моря арктический двурогий ицел отмечен нами в северо-восточной части между архипелагами Новая Земля и Земля Франца-Иосифа, где его численность составляла от 3 до 9 экз/км ${ }^{2}$, а биомасса - от 0.004 до 0.048 кг/км² (рис. 1, табл. 1). Восточный двурогий ицел в этом районе Баренцева моря не был обнаружен.

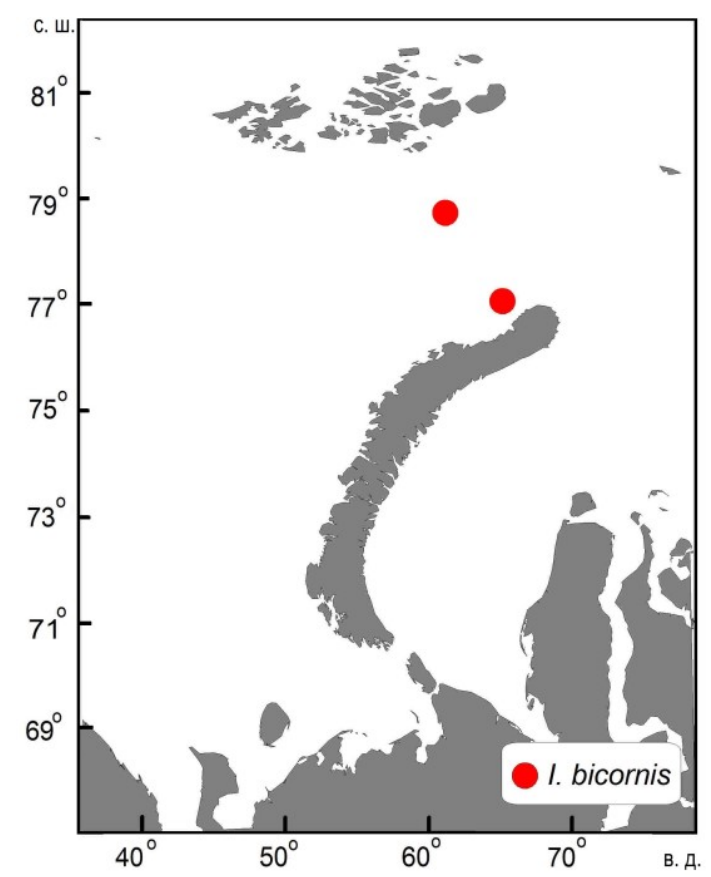

Рис. 1. Места поимок арктического двурогого ицела в Баренцевом море в ноябре 2019 г.

Fig. 1. Catch spots of twohorn sculpin in Barents Sea in November 2019

При исследованиях ихтиофауны юго-западной части Карского моря в уловах обнаружены оба вида, причем арктический двурогий ицел встречался как в прибрежной зоне, так и в открытых районах (рис. 2). Его численность варьировала в пределах 3-8 экз/км², а биомасса - 0.0020.048 кг/км ${ }^{2}$. Восточный двурогий ицел отмечен только в более мористых районах, где его численность составила от 3 до 6 экз/км², а биомасса от 0.011 до 0.055 кг/км² (табл. 1). 
Количественные показатели численности $(N)$ и биомассы $(B)$ представителей рода Icelus в арктических морях в 2014-2019 гг.

Table 1

Quantitative indicators of the abundance $(N)$ and biomass $(B)$ of representatives of the genus Icelus in the Arctic seas during (2014-2019)

\begin{tabular}{|c|c|c|c|c|}
\hline \multirow{2}{*}{ Mope } & \multicolumn{2}{|c|}{ Icelus bicornis } & \multicolumn{2}{|c|}{ Icelus spatula } \\
\hline & $N$, экз/км ${ }^{2}$ & $B, \mathrm{\kappa} \Gamma / \mathrm{KM}^{2}$ & $N$, экз/км ${ }^{2}$ & $B$, кг/км ${ }^{2}$ \\
\hline Баренцево & $3-9$ & $0.004-0.048$ & - & - \\
\hline Карское & $3-8$ & $0.002-0.048$ & $3-6$ & $0.011-0.055$ \\
\hline Лаптевых & $2-18$ & $0.005-0.089$ & $2-15$ & $0.005-0.11$ \\
\hline Восточно-Сибирское & 5 & 0.02 & $2-21$ & $0.002-0.699$ \\
\hline
\end{tabular}

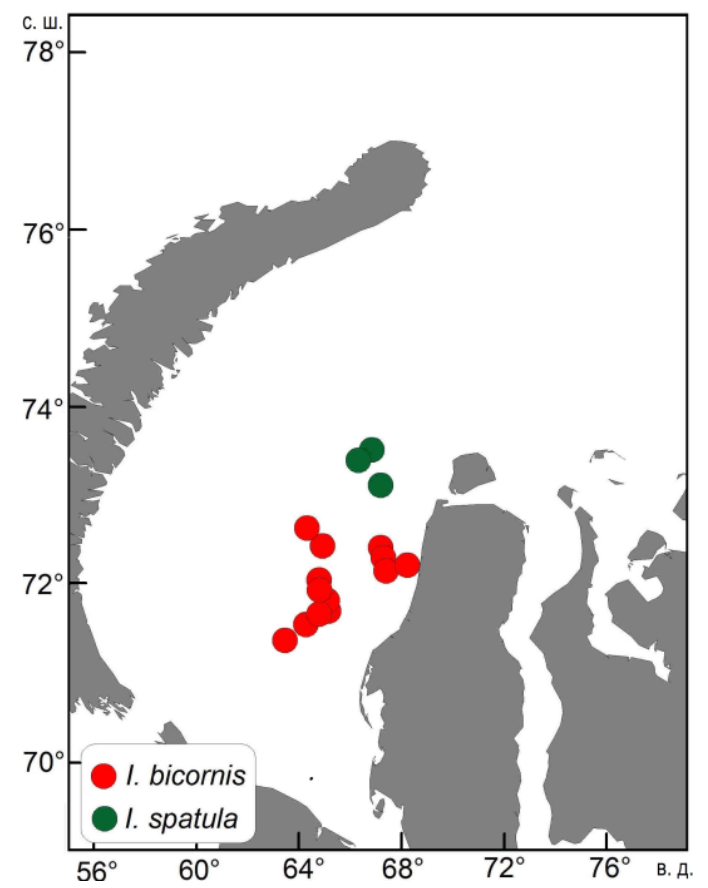

Рис. 2. Места поимок представителей рода Icelus в Карском море

Fig. 2. Catch spots of representatives of the genus Icelus in the Kara Sea

Исследования ихтиофауны в море Лаптевых показали, что оба рассматриваемых вида встречаются здесь в относительно обособленных районах. Арктический двурогий ицел в большей степени распространен в западной части обследованной акватории, где его численность была достаточно низкой - 2-18 экз/км ${ }^{2}$ при биомассе от 0.005 до 0.089 кг/км (рис. 3). Восточный двурогий ицел встречался как в западной, так и в восточной части моря Лаптевых. Численность этого вида варьировала от 2 до 15 экз $/$ км² $^{2}$, биомасса - от 0.005 до 0.110 кг $/$ км$^{2}$ (табл. 1).

В Восточно-Сибирском море преобладающим видом по встречаемости является восточный двурогий ицел (рис. 4). Численность представителей этого вида на обследованной акватории варьировала от 2 до 21 экз/км ${ }^{2}$, биомасса - от 0.002 до 0.699 кг/км². Арктический двурогий ицел отмечен 
в Восточно-Сибирском море только на одной, наиболее восточной станции, где плотность распределения составила 5 экз $/ \mathrm{\kappa м}^{2}$, а биомасса 0.02 кг/км² (табл. 1).

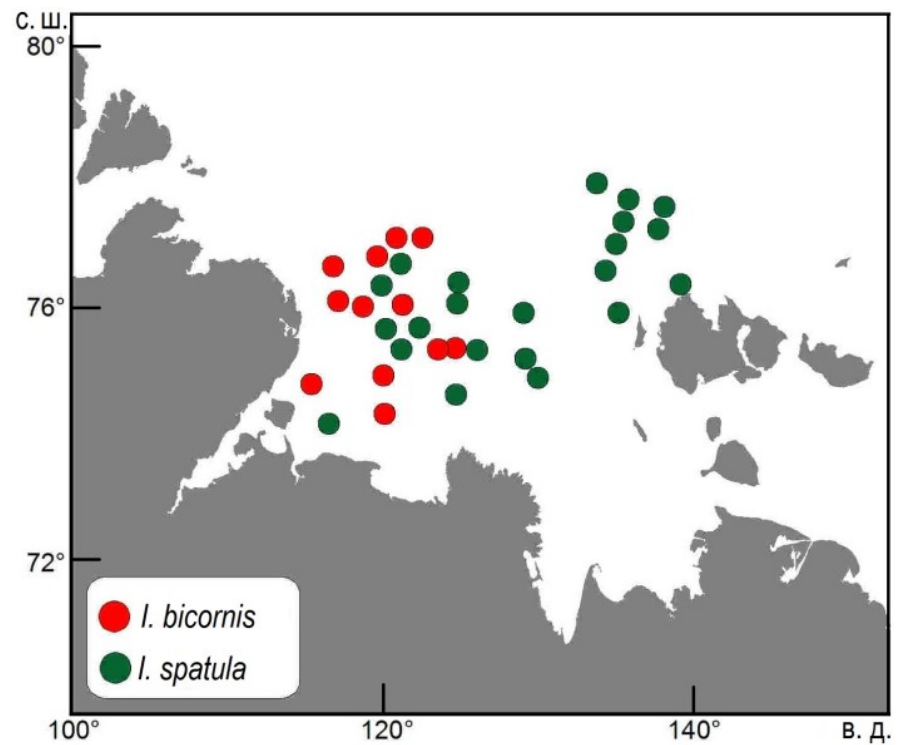

Рис. 3. Места поимок представителей рода Icelus в море Лаптевых

Fig. 3. Catch spots of representatives of the genus Icelus in the Laptev Sea

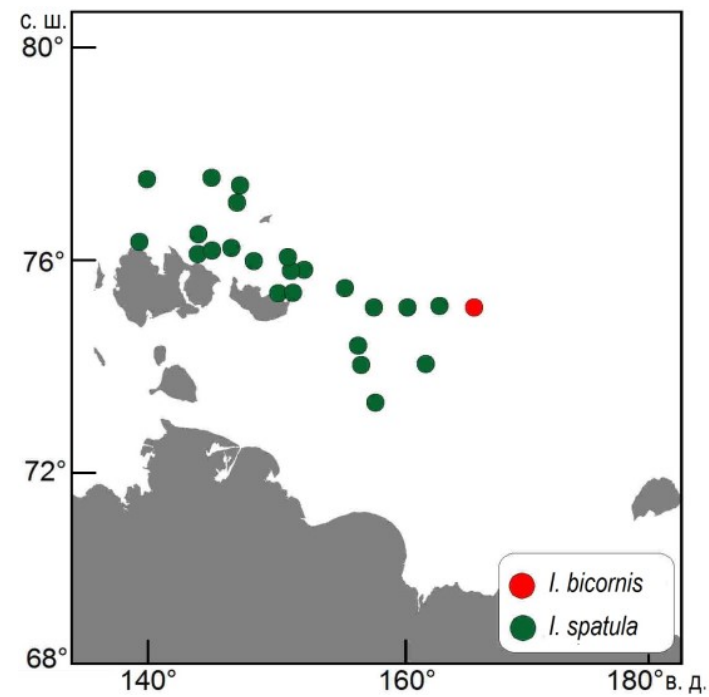

Рис. 4. Места поимок представителей рода Icelus в Восточно-Сибирском море

Fig. 4. Catch spots of representatives of the genus Icelus in the East-Siberian Sea

Соотношение видов в уловах меняется с запада на восток (табл. 2). В Баренцевом и Карском морях преобладает арктический двурогий ицел, в море Лаптевых и Восточно-Сибирском море его доля существенно ниже. Встречаемость восточного двурогого ицела имеет противоположную тенденцию. 
Т а бл и ц а 2

Доля видов рода Icelus в арктических морях в 2014-2019 гг., \%

$\mathrm{Tab} 1 \mathrm{e} 2$

The ratio of representatives of the genus Icelus in the Arctic seas (2014-2019), \%

\begin{tabular}{c|c|c|c|c}
\hline Вид & $\begin{array}{c}\text { Баренцево } \\
\text { море }\end{array}$ & $\begin{array}{c}\text { Карское } \\
\text { море }\end{array}$ & $\begin{array}{c}\text { Море } \\
\text { Лаптевых }\end{array}$ & $\begin{array}{c}\text { Восточно- } \\
\text { Сибирское море }\end{array}$ \\
\hline Icelus bicornis & 100 & 81 & 33 & 4 \\
Icelus spatula & 0 & 19 & 67 & 96
\end{tabular}

Глубина поимок арктического двурогого ицела во всех обследованных морях составила от 19 до 187 м. Максимальная глубина встречаемости этого вида значительно больше, чем у восточного двурогого ицела 13.5-71 м (рис. 5).
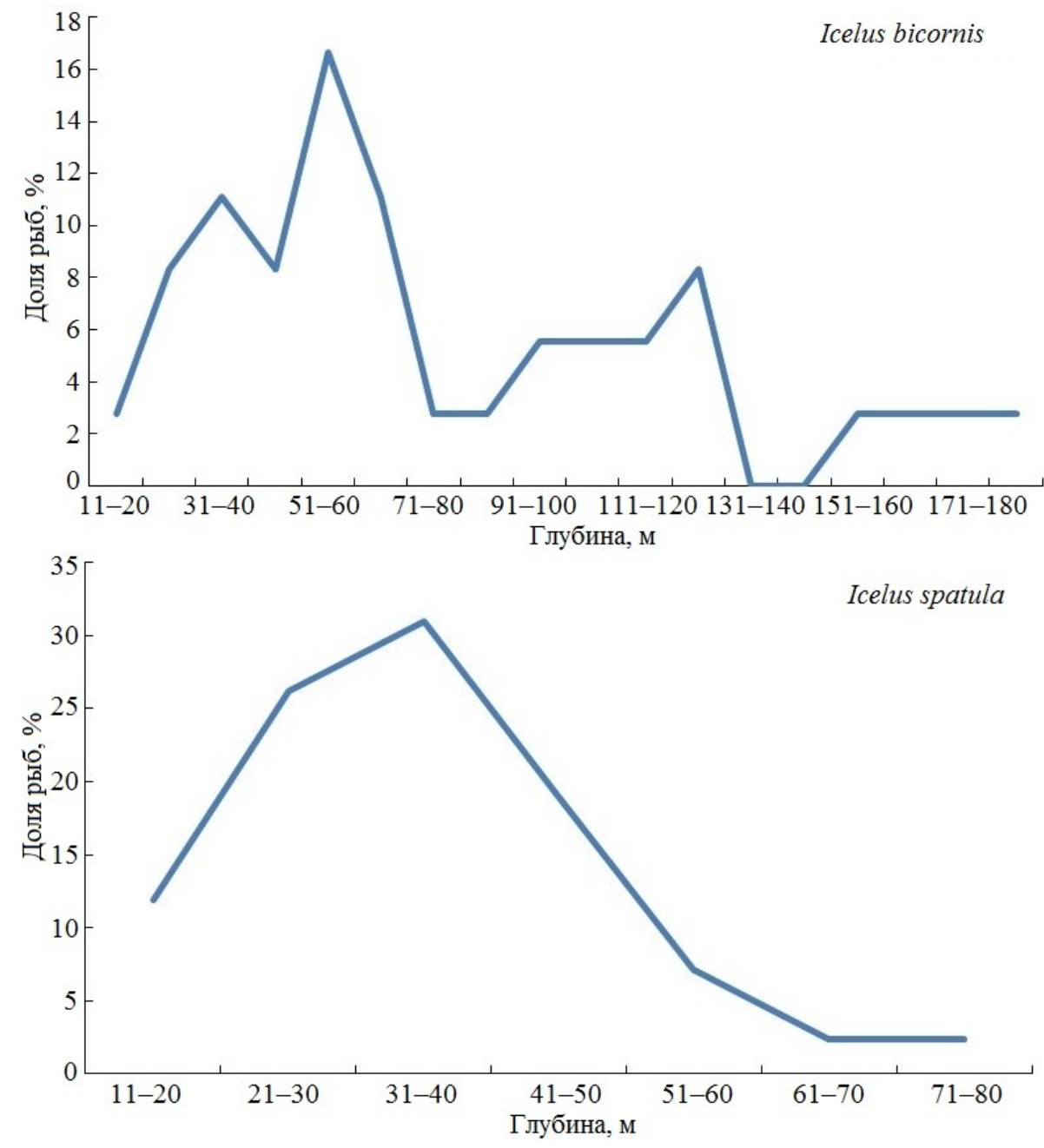

Рис. 5. Вертикальное распределение представителей рода Icelus в арктических морях в 2014-2019 гг.

Fig. 5. Vertical distribution of representatives of the genus Icelus in the Arctic seas (2014-2019) 
Наибольшее число поимок Icelus bicornis зарегистрировано на глубине 30-70 м. Также почти $10 \%$ от общего числа пойманных особей отмечено на глубине 120-130 м. Возможно, это объясняется различием в местообитаниях неполовозрелых особей и взрослых рыб (Есипов, 1952).

Для восточного двурогого ицела максимальная встречаемость рыб отмечена на глубине 20-40 м (57 \% общего количества), а с увеличением глубины число поимок существенно уменьшается.

Заключение. В результате проведенных исследований получены данные, подтверждающие встречаемость двух видов рода Icelus во всех обследованных районах. Максимальные показатели численности и биомассы арктического двурогого ицела Icelus bicornis отмечены в море Лаптевых (соответственно, 2-18 экз/км², 0.005-0.089 кг/км ${ }^{2}$ ), а для восточного двурогого ицела Icelus spatula в Восточно-Сибирском море (соответственно, 2-21 экз/км², 0.002-0.699 кг/км²).

Соотношение видов в уловах существенно меняется с запада на восток. В Баренцевом и Карском морях преобладает Icelus bicornis, тогда как в море Лаптевых и Восточно-Сибирском море - Icelus spatula.

Максимальные глубины обитания двух видов значительно различаются, составляя у Icelus bicornis 187 м, а у Icelus spatula $71 \mathrm{~m}$.

\section{Литература}

Андриямев А.П. Рыбы северных морей СССР. М.; Л.: Изд-во АН СССР, 1954. $566 \mathrm{c}$.

Боркин И.В. Состав рыбного населения прибрежных вод // Среда обитания и экосистемы Земли Франца-Иосифа (архипелаг и шельф). Апатиты: Изд-во КФ AH CCCP, 1994. C. 177-185.

Боркин И.В., Васильев А.В., Четыркина О.Ю. Ихтиофауна // Экосистема Карского моря. Мурманск: Изд. ПИНРО, 2008. С. 130-207.

Ecunoв В.К. Рыбы Карского моря. М.: Изд-во АН СССР, 1952. 146 с.

Инструкции и методические рекомендации по сбору и обработке биологической информации в морях европейского Севера и Северной Атлантики. М.: Изд-во ВНИРО, 2004. 300 с.

Методическое пособие по изучению питания и пищевых отношений рыб в естественных условиях. М.: Наука, 1974. 254 с.

Неелов А.В., Чернова Н.В. Предварительные сведения о рыбах, собранных в море Лаптевых в период экспедиции на л/с "Polarstern" в 1993 г. // Научные результаты экспедиции ЛАПЭКС-93. СПб.: Гидрометеоиздат, 1994. С. 272-276.

Неелов А.В., Чернова Н.В. Результаты исследований ихтиофауны в районе шельфа и континентального склона архипелага Шпицберген в рейсе ледокола "Поларштерн" ARK VIII/2 1991 ("EPOS II" = "SEAS") // Арктика и Антарктика. 2005. Вып. 4(38). С. 130-170. $376 \mathrm{c}$.

Правдин И.Ф. Руководство по изучению рыб. М.: Пищ. пром-сть, 1966.

Atlas of the Barents Sea fishes / R. Wienerroither, E. Johannesen, A. Dolgov et al. // IMR-PINRO Joint Rept. 2011. Ser. 1. 273 p. 
Byrkjedal I., Høines A. Distribution of demersal fish in the south-western Barents Sea // // Polar Research. 2007. Vol. 26. P. 135-151.

Jensen A.S., Volsøe H. A revision of the genus Icelus (Cottidae) with remarks on the structure of its urogenital papilla. Det. Kongelige Danske Videnskabernes Selskab. Ser. Biologiske meddelelser. København: I kommission hos Ejnar Munksgaard, 1949. Vol. 21(6). 31 p.

Marine fishes of the Arctic region / C.W. Mecklenburg, A. Lynghammar, E. Johannsen et al. Akureyri: CAFF (Conservation of Arctic Flora and Fauna), 2018. Vol. 1. 454 p.

McAllister D.E. Systematic notes on the sculpin genera Artediellus, Icelus and Triglops on Arctic and Atlantic coasts of Canada // Bull. Natl. Mus. Can. 1962. Vol. 185. P. 50-59.

Nelson D.W. Systematics and distribution of cottid fishes of the genera Rastrinus and Icelus. San-Francisco: Occas. Pap. Calif. Acad. Sci., 1984. № 138. 58 p.

DOI: $10.37614 / 2307-5252.2021 \cdot 3 \cdot 9.019$

УДК 57.08

А.П. Яковлев

Мурманский морской биологический институт РАН, г. Мурманск, Россия

РАЗРАБОТКА ЭКСПЕРИМЕНТАЛЬНОЙ УСТАНОВКИ ДЛЯ ИССЛЕДОВАНИЯ МАГНИТОРЕЦЕПЦИИ У СЕРЫХ ТЮЛЕНЕЙ

\section{Аннотация}

Некоторыми исследователями было высказано предположение, что китообразные во время своих миграций используют геомагнитное поле Земли для ориентации. Ластоногие также совершают длительные миграции в открытом море при отсутствии явных ориентиров, что может свидетельствовать о наличии у них магнитного чувства. В работе описаны разработка и конструирование экспериментального стенда, в основе которого лежат кольца Гельмгольца, для изучения магниторецепции у серых тюленей. Приводится методика "выбор объекта с заданными характеристиками", адаптированная для проведения экспериментов с ластоногими.

Ключевые слова: магниторецепция, условный рефлекс, серые тюлени.

\section{A.P. Yakovlev}

Murmansk Marine Biological Institute RAS, Murmansk, Russia

\section{DEVELOPMENT OF AN EXPERIMENTAL INSTALLATION FOR GRAY SEAL MAGNETORECEPTION RESEARCH}

\section{Abstract}

The assumption was made that Cetaceans, both whales and dolphins, are using geomagnetic field of Earth for orientations during migration. Pinnipeds also make 
long-distance migrations in open seas without apparent reference point. That may be an evidence of magnetic sense in pinnipeds. In this paper we describe development and construction of experimental installation based on Helmholtz coil for gray seal magnetoreception research. A technique of "selection of an object with specified characteristics" is described, adapted for conduction of experiments with pinnipeds.

Keywords: magnetoreception, conditioned reflex, gray seals.

Введение. Магнитные и электрические поля являются частью окружающей среды каждого живого организма (Skiles, 1985). Многие из них (от бактерий и простейших до птиц и млекопитающих) способны воспринимать геомагнитные сигналы (Wiltschko, Wiltschko, 2005). Организмы реагируют на направление, величину и наклон геомагнитного поля.

Магнитная ориентация широко распространена в водной среде и связана как с миграциями на большие расстояния, так и с локальными перемещениями (Johnsen, Lohmann, 2008). Есть свидетельства, что морские черепахи, рыбы и ракообразные обладают способностью воспринимать магнитные карты (Mouritsen, 2018). Было высказано предположение, что китообразные (киты и дельфины) во время своих миграций ориентируются с помощью геомагнитных сигналов. К примеру, места наблюдений финвалов Belaenoptera physalus на северо-востоке США коррелировали с районами, где наблюдалась низкая геомагнитная активность во время их регистраций, а зависимость от рельефа дна и глубины не прослеживалась, что указывает на использование геомагнитных сигналов для навигации (Evidence ..., 1992). В неволе дельфины-афалины Tursiops truncates приближались к магнитному объекту быстрее, чем к идентичному немагнитному объекту, что указывает на магнитное чутье (Behavioural ..., 2014).

Китообразные и ластоногие совершают длительные миграции на большие расстояния. И если использование магниторецепции китообразными широко обсуждается в научном сообществе, то исследования, посвященные восприятию магнитных полей ластоногими, практически отсутствуют. Например, сезонные миграции беломорской популяции гренландского тюленя охватывают значительную часть Северной Атлантики с прилегающими морями - Баренцевым, Гренландским и Норвежским, а также Карское море. Миграция идет в направлении от северной границы Белого моря на северо-запад вдоль берегов Скандинавского полуострова. Тюлени достигают вод у Шпицбергена, затем следуют вдоль ледовой кромки между архипелагами Шпицберген и Земля Франца-Иосифа, далее направляются на юг вдоль западного побережья Новой Земли, на юго-восток Баренцева моря и далее в Белое море (Чапский, 1938; Nilssen, 1995; Seasonal ..., 2008). Тюлени, совершая миграции в открытом море, практически лишены визуальных ориентиров, а значительные глубины не позволяют использовать рельеф 
дна для ориентации. Логично предположить, что и ластоногие могут использовать геомагнитное поле для ориентации при совершении длительных миграций, т. е. могут обладать магниторецепцией.

Материалы. Для создания магнитного поля используется генератор сигналов произвольной формы АКИП-3418/1, который представляет собой 16-битный генератор сигналов специальной и произвольной формы, с помощью которого можно создавать сигналы высокой точности. При помощи коаксиального кабеля через переключатель к генератору подключаются кольца Гельмгольца, закрепленные на экспериментальном стенде (рис. 1).

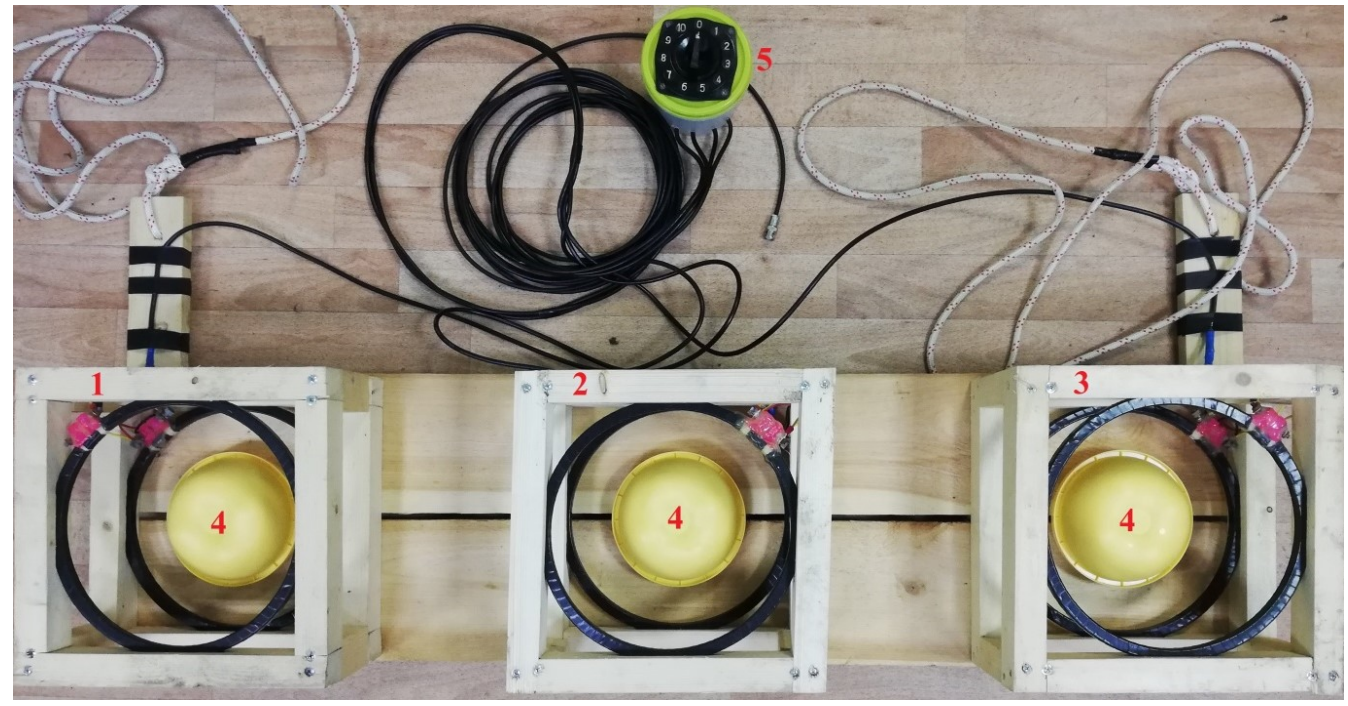

Рис. 1. Экспериментальный стенд (вариант 2):

1, 2, 3 - кольца Гельмгольца, закрепленные при помощи деревянных рамок на стенде; 4 - таргет; 5 - переключатель каналов подачи сигнала

Fig. 1. Experimental stand (option 2):

1, 2, 3 - Helmholtz rings fixed with wooden frames on the stand; 4 - target; 5 - signal channel switch

Поскольку две магнитные катушки конструируются так, чтобы быть идентичными, при равенстве радиуса катушек расстоянию между ними, внутри последних образуется однородное магнитное поле. Две катушки соединены последовательно таким образом, чтобы их питал одинаковый ток, который создавал бы два одинаковых магнитных поля. При сложении два поля создают однородное магнитное поле в цилиндрическом объеме в центре пространства между двумя параллельными катушками.

Это однородное поле занимает объем пространства цилиндрической формы, имеющий радиус примерно равный $25 \%$ от радиуса катушки и длину, соответствующую 50 \% от расстояния между катушками. Кольца Гельмгольца генерируют магнитные поля во всех направлениях 3-мерного пространства внутри пары катушек. 
Каждая катушка Гельмгольца представляет собой два кольца диаметром 25 см, на внешней стороне которых имеется паз для намотки медной проволоки, поверх которого размещается защитный кожух. Кольца и защитный кожух изготовлены из полиэтилена. Каждое из двух колец имеет 300 витков медной изолированной проволоки диаметром 0.2 мм, т. е. на каждом кольце намотано 235.6 м проволоки. После установки защитного кожуха кольцо изолировалось при помощи изоленты и силикона для исключения попадания внутрь конструкции морской воды. Клеммы для подключения внутреннего и внешнего контакта проволоки выведены на специальные выступы в защитном кожухе.

Для двух серий экспериментов изготовлены следующие варианты экспериментального стенда: А - стенд с двумя парами колец Гельмгольца; Б - с тремя парами (рис. 2).
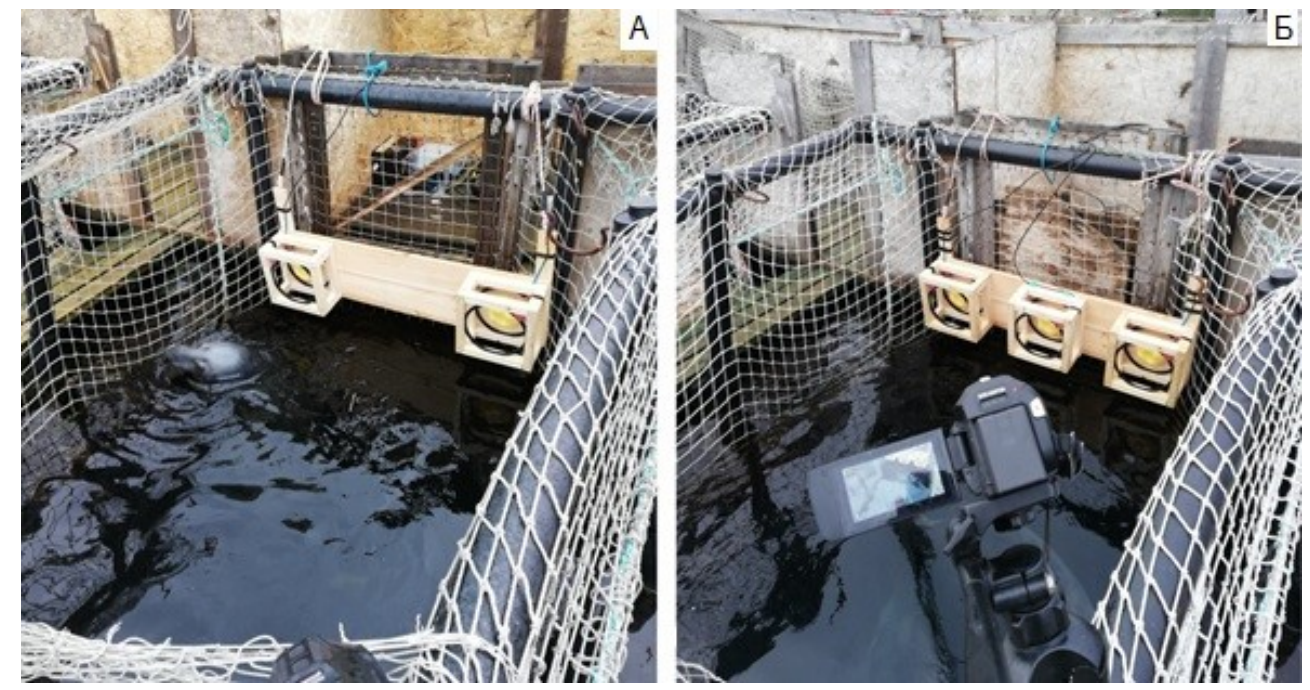

Рис. 2. Экспериментальный стенд. Пояснение в тексте

Fig. 2. Experimental stand. Explanation in the text

Кольца Гельмгольца были закреплены на экспериментальном стенде при помощи деревянного каркаса. Согласно правилу изготовления, для получения магнитного поля с наибольшей индуктивностью, расстояние между кольцами равнялось радиусу колец, т. е. 12.5 см в нашей конструкции. Кольца были подключены последовательно с целью получения равномерного постоянного магнитного поля внутри них. Каждая пара колец была соединена коаксиальным кабелем с переключателем каналов, который имеет 10 независимых выходов и положение “ноль”, при котором сигнал не подается ни на один из выходов. Переключатель каналов, в свою очередь, соединялся с генератором сигналов с помощью коаксиального кабеля. Сигнал на переключатель поступал с двух независимых выходов генератора, тем самым достигались максимальные значения генерируемой магнитной индукции на катушках Гельмгольца. 
Был выполнен расчет магнитной индукции, которую способны выработать изготовленные катушки Гельмгольца. Теоретическая величина индукции составила 140 мкТл. Для измерений фактической магнитной индукции, производимой нашими катушками Гельмгольца, был использован магнитометр.

Максимальные значения магнитной индукции (125-130 мкТл) были получены при генерации постоянного магнитного поля синусоидальной формы при подаваемом напряжении 10 В и частоте сигнала 20-50 Гц. При частоте сигнала 2-20 Гц, индукция находилась на уровне 110 120 мкТл.

Методы. В качестве основы проведения экспериментов были взяты методы условного рефлекса, как один из наиболее информативных для экспериментального изучения функционального состояния высших отделов ЦНС (Павлова и др., 2013) и выбор объекта по заданному признаку. Эти методы были нами адаптированы под объект исследования и поставленные цели экспериментов.

В первой серии экспериментов тюлени должны дифференцировать объект по наличию магнитного поля, выбирая из двух пар катушек Гельмгольца ту, в которой на данный момент генерируется магнитное поле с определенным значением индукции (рис. 2А). Во второй серии экспериментов животные должны выбрать одну из трех пар катушек Гельмгольца, на которую подавался сигнал от генератора (рис. 2Б). Каждая из двух серий экспериментов состоит из двух идентичных этапов.

Первый этап заключается в предъявлении нового для тюленя стимула - магнитного поля частотой 8,20 и 36 Гц и магнитной индукции внутри катушек 110, 115 и 130 мкТл соответственно. Экспериментальный стенд закрепляется на уровне 10-15 см выше уреза воды, тренер находится на противоположной стороне вольера. Тюлень занимает стартовую позицию в воде на стороне вольера, рядом с тренером. По команде “ищи” животное должно подплыть к экспериментальному стенду и выбрать из двух или трех катушек ту, в которой в данный момент генерируется магнитное поле. Выбор обозначается касанием морды таргета желтого цвета, закрепленного в центре катушек Гельмгольца на экспериментальном стенде (рис. 1), тюлень должен удерживать морду, касаясь его не менее 5 с. При верном выборе следует бридж-сигнал и пищевое подкрепление.

Второй этап заключается в проведении контрольных экспериментов с видеофиксацией для последующей обработки и статистического анализа. Для каждого опыта составляется протокол проведения эксперимента из тридцати повторностей за тренировку с порядком включения одной из двух (в первой серии опытов) или одной из трех (во второй серии опытов) катушек Гельмгольца. Последовательность включения катушек определяется псевдослучайным образом, с условием не более трех предъявлений одной и той же катушки подряд. 
Обсуждение. При изучении магниточувствительности животных приходится встречаться с двумя главными проблемами. Первая из них связана с тем, что многие поведенческие результаты небезупречны с методологической точки зрения, не всегда воспроизводимы и не информативны в отношении функционирования "магнитного чувства". Вторая трудность заключается в том, что пока неизвестно, где именно и каким образом детектируется магнитное поле (Able, 1980). Поэтому трудно спланировать и осуществить “решающие” опыты, чтобы получить нужные поведенческие, анатомические и нейрофизиологические доказательства наличия этого чувства у животных и проанализировать его возможности.

Опыты с условными рефлексами могли бы обеспечить нужную воспроизводимость и убедительность результатов, если требуется доказать факт магниточувствительности.

Первое, что следует проверить в экспериментах с выработкой условных рефлексов - это могут ли животные различать разные магнитные стимулы. Поэтому, прежде всего, должны быть выбраны процедуры, позволяющие выяснить этот вопрос. Необходимо подобрать экспериментальную ситуацию, процедуру испытаний, способ оценки реакций, характер реакций и стимулов, подлежащих различению. Когда будет установлено, что животное различает интересующие нас стимулы, дальнейшие детали исследования будут определяться проверяемой гипотезой (Kling, 1971).

В экспериментах с условным рефлексом будет выявляться научение, т. е. относительно устойчивое изменение поведения, обусловленное индивидуальным опытом (Kling, 1971). В частности, в экспериментах с дискриминативным научением видоизменяется какая-то доступная для измерения особенность поведения, приобретаемая в ходе обучения. При унитарной процедуре определяют ответ (да, нет), который в разных условиях стимуляции получает положительное или отрицательное подкрепление. Дискриминативное научение можно оценить при сравнении готовности отвечать на разные стимулы (Bitterman, 1966).

Магнитные поля - это стимулы, проникающие повсеместно, поэтому в экспериментальных ситуациях их можно предьявлять только последовательно по одному. Эксперименты с дифференцировкой, в которых стимулами служат магнитные поля, принадлежат к числу наиболее трудных для подопытных животных (Mackintosh, 1974).

Поэтому при изучении восприятия магнитных полей предпочтительна унитарная схема, а не опыты со сложными дифференцировками. Подобная схема эксперимента дает испытуемым свободу передвижения (Kreithen, Keeton, 1974) и предоставляет им достаточно времени, чтобы ознакомиться с окружающей магнитной обстановкой и многократно прореагировать на нее во время испытаний. 


\section{Литература}

Павлова Л.Н., Жаворонков Л.П., Дубовик Б.В. Влияние низкоинтенсивного широкополосного импульсно-модулированного электромагнитного поля на когнитивные функции мозга крыс // Радиация и риск. 2013. Т. 22, № 2. C. 91-100.

Чапский К.К. Новейшие данные о распределении беломорской расы гренландского тюленя вне беломорского района // Проблемы Арктики. 1938. № 4. C. $105-131$.

Able K.P. Mechanisms of orientation, navigation, and homing // Animal migration, orientation and navigation. New York: Acad. Press, 1980. P. 283-373.

Behavioural evidence of magnetoreception in dolphins: detection of experimental magnetic fields / D. Kremers, J.L. Marulanda, M. Hausberger, A. Lemasson // Naturwissenschaften. 2014. Vol. 101(11). P. 907-911.

Bitterman M.E. Animal learning // Experimental methods and instrumentation in psychology. New York: McGraw-Hill, 1966. P. 451-484.

Evidence that fin whales respond to the geomagnetic field during migration / M.M. Walker, J.L. Kirschvink, G. Ahmed, A.E. Dizon // J. Exp. Biol. 1992. Vol. 171(1). P. 67-78.

Johnsen S., Lohmann K.J. Magnetoreception in animals // Feature Article. Phys. Today. 2008. Vol. 61(3). P. 29.

Kling J.W. Learning: Introductory survey // Woodworth and schlosberg's experimental psychology. New York: Holt, Rinehart and Winston, 1971. P. 551-613.

Kreithen M.L., Keeton W.T. Attempts to condition homing pigeons to magnetic stimuli // J. Comp. Physiol. 1974. Vol. 91. P. 355-362.

Mackintosh N.J. The psychology of animal learning. New York: Acad. Press, 1974. $730 \mathrm{p}$.

Mouritsen $H$. Long-distance navigation and magnetoreception in migratory animals // Nature. 2018. Vol. 558(7708). P. 50.

Nilssen K.T. Seasonal distribution, condition and feeding habits of Barents Sea harp seal (Phoca groenlandica) // Whales, seals, fish and man. Amsterdam, Lausanne, New York, Oxford, Shannon and Tokyo: Elsevier, 1995. P. 241-254.

Seasonal distribution and dive behaviour of harp seals (Pagophilus groenlandicus) of the White Sea-Barents Sea stock / E.S. Nordøy, L.P. Folkow, V. Potelov et al. // Polar Biology. 2008. Vol. 31. P. 1119-1135.

Skiles D.D. The geomagnetic field: its nature, history and biological relevance // Magnetite biomineralization and magnetoreception by living organisms: a new biomagnetism. New York: Plenum Press, 1985. P. 43-102.

Wiltschko W., Wiltschko R. Magnetic orientation and magnetoreception in birds and other animals // J. Comp. Physiol. 2005. Vol. 191(8). P. 675-693. 
$\frac{\text { Pरव }}{\text { रमे }}$ 